\title{
ॠUSGS
}

science for a changing world

Prepared in cooperation with the Bureau of Reclamation

\section{Benthic Processes Affecting Contaminant Transport in Upper Klamath Lake, Oregon}

By James S. Kuwabara, Brent R. Topping, James L. Carter, Rick A. Carlson, Francis Parchaso, Steven V. Fend, Natalie Stauffer-Olsen, Andrew J. Manning, and Jennie M. Land

Open-File Report 2016-1175

Version 1.1, October 2016

U.S. Department of the Interior U.S. Geological Survey 
Cover. Sunrise over Upper Klamath Lake, fall 2015. Photograph by Francis Parchaso of the U.S. Geological Survey. 


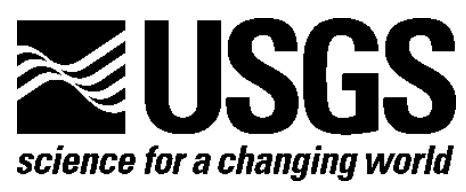

Prepared in cooperation with the Bureau of Reclamation

\section{Benthic Processes Affecting Contaminant Transport in Upper Klamath Lake, Oregon}

By James S. Kuwabara, Brent R. Topping, James L. Carter, Rick A. Carlson, Francis Parchaso, Steven V. Fend, Natalie Stauffer-Olsen, Andrew J. Manning, and Jennie M. Land

Open-File Report 2016-1175

Version 1.1, October 2016

U.S. Department of the Interior

U.S. Geological Survey 


\title{
U.S. Department of the Interior SALLY JEWELL, Secretary
}

\section{U.S. Geological Survey \\ Suzette M. Kimball, Director}

\author{
U.S. Geological Survey, Reston, Virginia \\ First release: 2016 \\ Revised: October 2016 (ver. 1.1)
}

For more information on the USGS-the Federal source for science about the Earth,
its natural and living resources, natural hazards, and the environment-visit
http://www.usgs.gov/ or call 1-888-ASK-USGS (1-888-275-8747).

For an overview of USGS information products, including maps, imagery, and publications, visit http://store.usgs.gov/.

Any use of trade, firm, or product names is for descriptive purposes only and does not imply endorsement by the U.S. Government.

Although this information product, for the most part, is in the public domain, it also may contain copyrighted materials as noted in the text. Permission to reproduce copyrighted items must be secured from the copyright owner.

Suggested citation:

Kuwabara, J.S., Topping, B.R., Carter, J.L., Carlson, R.A., Parchaso, F., Fend, S.V., Stauffer-Olsen, N., Manning, A.J., Land, J.M., 2016, Benthic processes affecting contaminant transport in Upper Klamath Lake, Oregon (ver. 1.1, October 2016): U.S. Geological Survey Open-File Report 2016-1175, 103 p., http://dx.doi.org/10.3133/ofr20161175.

ISSN 2331-1258 (online) 


\section{Acknowledgments}

The authors are grateful for critical logistical support from E. Janney and other personnel from the U.S. Geological Survey (USGS) Field Office in Klamath Falls, Oregon, and from the USGS Oregon Water Science Center. Insightful reviews by M. Gannett and T. Wood are much appreciated, as are hydraulic conductivity determinations by K. Halford. Participation in the design, implementation, and analyses of field studies by R. Anduaga, M. Berry, J. Brotherton, S. Burdick, R. Carlson, J. Crauder, K. Doughty, D. Eldridge, S. Eldridge, A. Englestadt, M. Green, M. Hornberger, J. Kissock, M. Kritzer, J. Land, C. McPhail, and G. Schanzenbacher, and T. Short was critical to its successful completion. J. Constantz, H. Essaid, P. Hsieh, R. Niswonger, and D. Rosenberry provided valuable consultation on methods to examine hydrologic interactions between the lakebed and overlying water column in Upper Klamath Lake. J. La Marche (Oregon Water Resources Department), M. Skinner (Klamath Tribes), and J. Gronberg (USGS California Water Science Center) are thanked for help accessing tributary discharge data. The Klamath Falls Office of the U.S. Bureau of Reclamation (Interagency Funding Agreement Number R13PG20052), the USGS Toxic Substances Hydrology Program, the USGS Water Availability and Use Program, USGS National Water Quality Program, and the National Research Program within the USGS Water Mission Area are also acknowledged for sustained support of this work. 


\section{Contents}

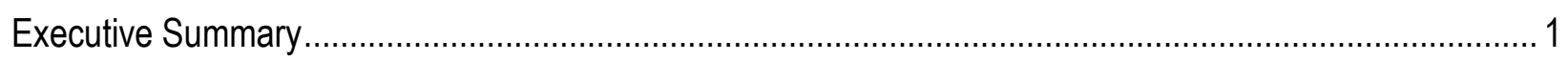

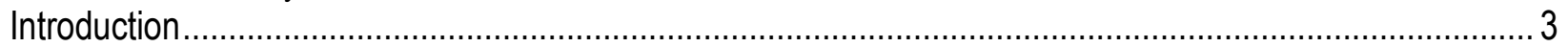

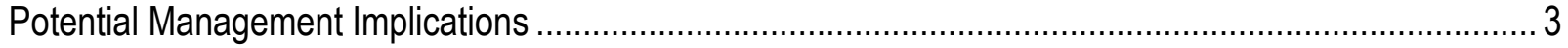

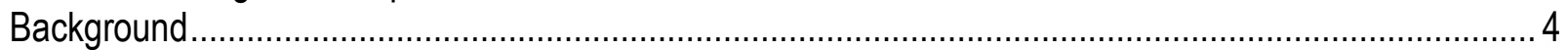

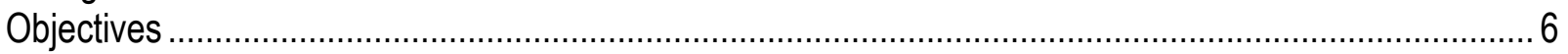

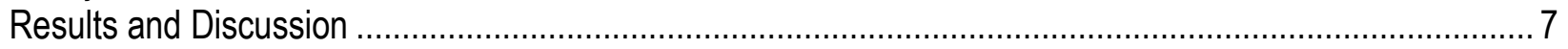

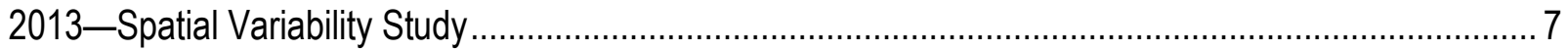

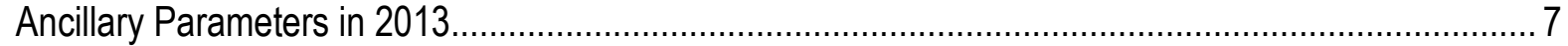

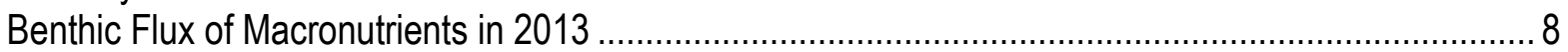

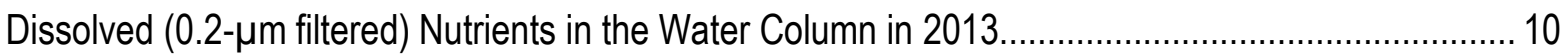

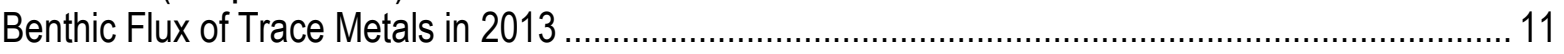

Dissolved (0.2- $\mu \mathrm{m}$ Filtered) Trace Elements in the Water Column in 2013 ................................... 13

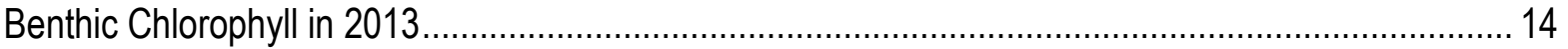

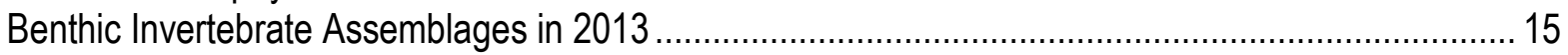

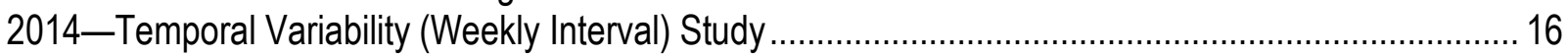

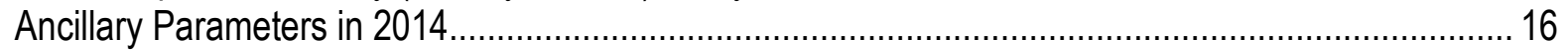

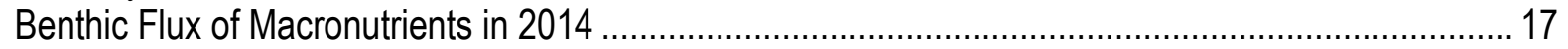

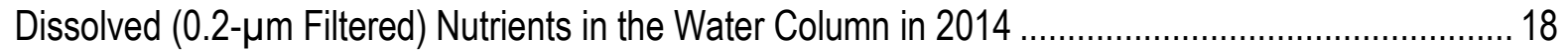

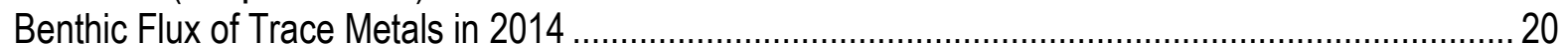

Dissolved (0.2- $\mu \mathrm{m}$ Filtered) Trace Elements in the Water Column in 2014 ..................................... 22

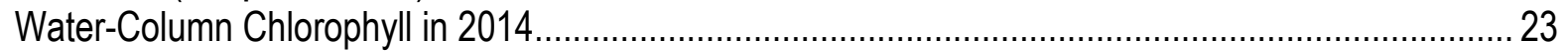

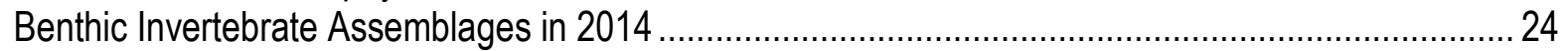

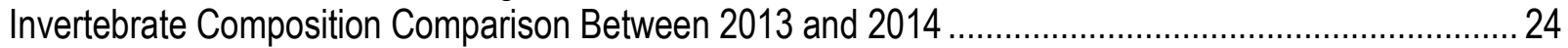

Invertebrate Composition Comparison to Previous Studies ...............................................................2 25

Biological Solute Efflux -Soluble Reactive Phosphorus (2011-2015) ................................................ 25

2015-Physical (Advective) Solute Transport and Particle Dynamics .................................................. 27

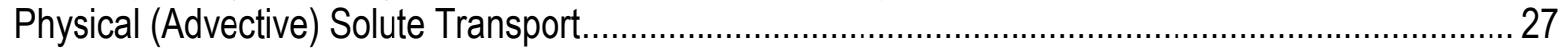

Organic Aggregation and Settling in Upper Klamath Lake ....................................................... 28

Overview of Particle Aggregation and Settling ……………..................................................... 29

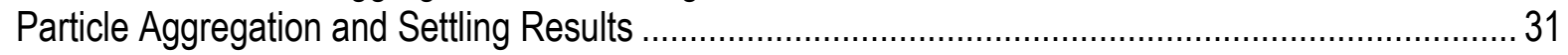

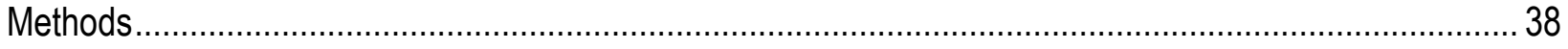

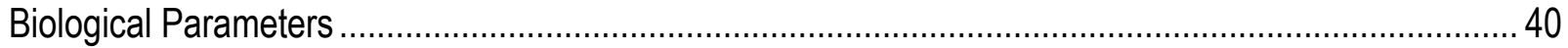

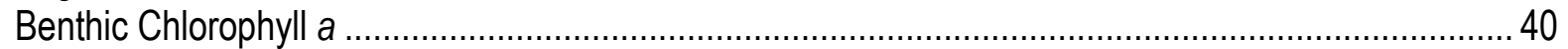

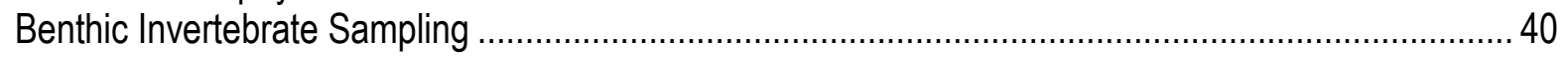

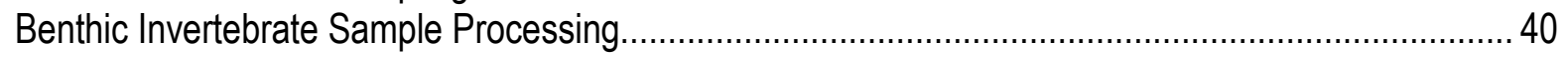

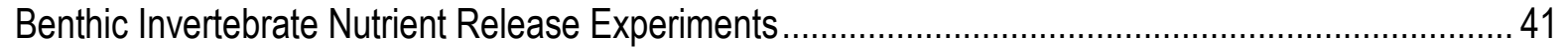

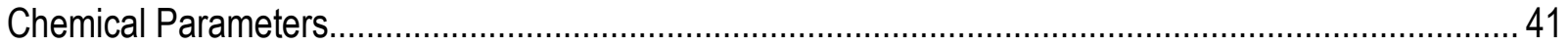

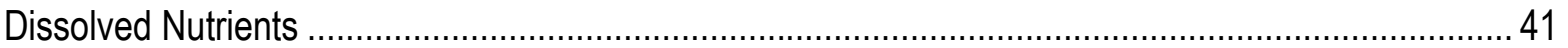

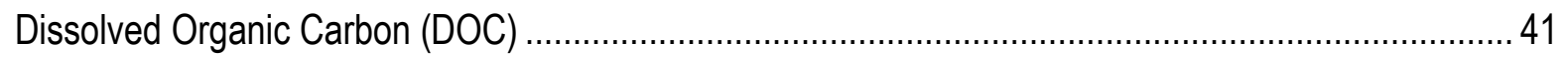

Dissolved Trace Elements................................................................................................... 42

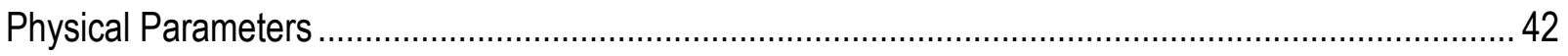

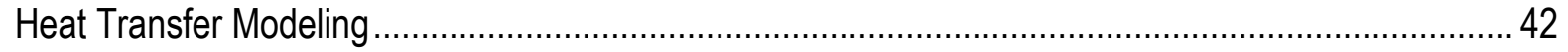

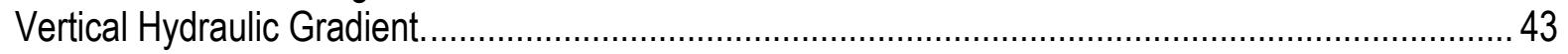

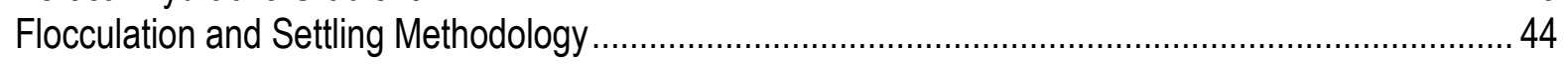

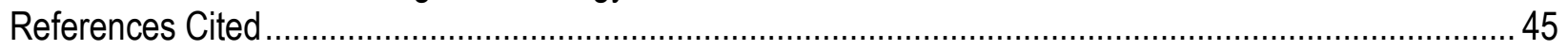




\section{Figures}

1. Map of Upper Klamath Lake and sampling sites for 2013, 2014, and 2015 ..............................5

2. Upper Klamath Lake organic aggregate (floc) size versus settling velocity population scatterplots..33

3. Photographs showing (a) a complete LabSFLOC-2 floc cam setup in a laboratory, with the settling column and camera on the left and computer with operating software and recording hard drive on the right. (b) Top view of U.S. Geological Survey (USGS) version of the LabSFLOC-2 floc cam setup in stainless steel housing in a Pelican waterproof case, with the camera and lens to the left and the settling column to the right. (c) July 2015, site LS01—collecting the near-surface floc sample directly from the water column using the modified pipette. (d) USGS Van Dorn sampler from same sampling. (e) Professor Manning transferring flocs...

4. Floc images from the LabSFLOC-2 floc cam collected during (a) the pre-bloom conditions, when Upper Klamath Lake is dominated by brown algae including diatoms. Leaf-like structures appear in the July sample (b), assumed to be individual Aphanizomenon flos-aquae (AFA) filaments.

Organic aggregates during bloom conditions (c) include cyanobacterial colonies ..... 35

5. Photograph showing a piezometer and thermistor string deployed at one of the northern littoralzone sites.

\section{Tables}

1. Sampling site locations and descriptions within and up gradient of Upper Klamath Lake, Oregon..54

2. Summary of results from 2013 sonde deployments in Upper Klamath Lake, Oregon.................... 55

3. 2013 dissolved (0.2-micrometer filtered) macronutrient benthic fluxes from profiler deployments.. 59

4. Riverine-flux estimates for dissolved (0.2-micrometer filtered) solutes into Upper Klamath Lake, Oregon.

5. 2013 dissolved (0.2-micrometer filtered) macronutrient concentrations in the water column of Upper

Klamath Lake, Oregon.....

6. 2013 dissolved (0.2-micrometer filtered) trace-element benthic fluxes from profiler deployments.. 66

7. 2013 dissolved (0.2-micrometer filtered) trace-element concentrations in the water column Upper Klamath Lake, Oregon.....

8. 2013 benthic chlorophyll and pheophytin concentrations in Upper Klamath Lake, Oregon, with associated temperature and specific-conductivity measurements.

9. Mean density of macroinvertebrates per square meter $\left(\mathrm{m}^{-2}\right)$, constancy (presence per sample), and percentage composition of 63 samples (21 samples per date) during 2013.

10. Summary of results from 2014 sonde deployments near site ON01 in Upper Klamath Lake, Oregon...

11. 2014 water-column and pheophytin concentrations in Upper Klamath Lake, Oregon, near site ON01.

12. 2014 Dissolved-macronutrient benthic fluxes from profiler deployments in Upper Klamath Lake,

Oregon, near site ON01....

13. Dissolved (0.2-micrometer filtered) macronutrient concentrations in the water column of Upper Klamath Lake, Oregon, near site ON01.

14. 2014 dissolved trace-element benthic fluxes from profiler deployments near site ON01.........

15. 2014 dissolved (0.2-micrometer filtered) trace-element concentrations in the water column of Upper Klamath Lake, Oregon, near site ON01. 
16. Mean density of macroinvertebrates per square meter $\left(\mathrm{m}^{-2}\right)$, mean density per sampling interval, constancy (presence per sample), and percentage composition of 27 weekly samples collected during 2014 at site ON01............................................................................................. 93

17. Taxonomic list of benthic invertebrates collected in 2013 and 2014 collections. ..........................96

18. Phosphorus release (efflux) by some of the most numerically dominant and widespread taxa residing in Upper Klamath Lake.

19. Potential importance of solute advective flux across the sediment-water interface. ....................100

20. Environmental variables and floc population properties, Upper Klamath Lake, Oregon,

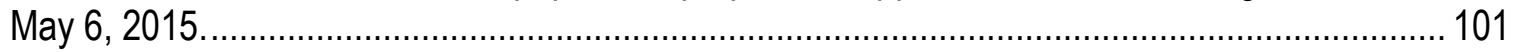

21. Environmental variables and floc population properties, Upper Klamath Lake, Oregon, July $30,2015$. 102

22. Environmental variables and floc population properties, Upper Klamath Lake, Oregon, October 6, 2015. 103 


\section{Conversion Factors}

\begin{tabular}{|c|c|c|}
\hline Multiply & By & To obtain \\
\hline \multicolumn{3}{|c|}{ Length } \\
\hline centimeter $(\mathrm{cm})$ & 0.3937 & inch (in.) \\
\hline millimeter (mm) & 0.03937 & inch (in.) \\
\hline meter $(\mathrm{m})$ & 3.281 & foot $(\mathrm{ft})$ \\
\hline kilometer $(\mathrm{km})$ & 0.6214 & mile (mi) \\
\hline \multicolumn{3}{|c|}{ Area } \\
\hline square meter $\left(\mathrm{m}^{2}\right)$ & 0.0002471 & acre \\
\hline square kilometer $\left(\mathrm{km}^{2}\right)$ & 247.1 & acre \\
\hline square centimeter $\left(\mathrm{cm}^{2}\right)$ & 0.001076 & square foot $\left(\mathrm{ft}^{2}\right)$ \\
\hline square meter $\left(\mathrm{m}^{2}\right)$ & 10.76 & square foot $\left(\mathrm{ft}^{2}\right)$ \\
\hline square centimeter $\left(\mathrm{cm}^{2}\right)$ & 0.1550 & square inch $\left(\mathrm{ft}^{2}\right)$ \\
\hline square kilometer $\left(\mathrm{km}^{2}\right)$ & 0.3861 & square mile $\left(\mathrm{mi}^{2}\right)$ \\
\hline \multicolumn{3}{|c|}{ Volume } \\
\hline liter (L) & 33.81402 & ounce, fluid (fl. oz) \\
\hline liter (L) & 0.2642 & gallon (gal) \\
\hline cubic meter $\left(\mathrm{m}^{3}\right)$ & 264.2 & gallon (gal) \\
\hline cubic decimeter $\left(\mathrm{dm}^{3}\right)$ & 0.2642 & gallon (gal) \\
\hline cubic meter $\left(\mathrm{m}^{3}\right)$ & 0.0002642 & million gallons (Mgal) \\
\hline cubic centimeter $\left(\mathrm{cm}^{3}\right)$ & 0.06102 & cubic inch $\left(\right.$ in $\left.^{3}\right)$ \\
\hline liter (L) & 61.02 & cubic inch $\left(\mathrm{in}^{3}\right)$ \\
\hline cubic meter $\left(\mathrm{m}^{3}\right)$ & 35.31 & cubic foot $\left(\mathrm{ft}^{3}\right)$ \\
\hline \multicolumn{3}{|c|}{ Flow rate } \\
\hline meter per second $(\mathrm{m} / \mathrm{s})$ & 3.281 & foot per second $(\mathrm{ft} / \mathrm{s})$ \\
\hline meter per day $(\mathrm{m} / \mathrm{d})$ & 3.281 & foot per day $(\mathrm{ft} / \mathrm{d})$ \\
\hline cubic meter per second $\left(\mathrm{m}^{3} / \mathrm{s}\right)$ & 35.31 & cubic foot per second $\left(\mathrm{ft}^{3} / \mathrm{s}\right)$ \\
\hline cubic meter per day $\left(\mathrm{m}^{3} / \mathrm{d}\right)$ & 35.31 & cubic foot per day $\left(\mathrm{ft}^{3} / \mathrm{d}\right)$ \\
\hline liter per second (L/s) & 15.85 & gallon per minute (gal/min) \\
\hline cubic meter per day $\left(\mathrm{m}^{3} / \mathrm{d}\right)$ & 264.2 & gallon per day (gal/d) \\
\hline cubic meter per second $\left(\mathrm{m}^{3} / \mathrm{s}\right)$ & 22.83 & million gallons per day $(\mathrm{Mgal} / \mathrm{d})$ \\
\hline \multicolumn{3}{|c|}{ Mass } \\
\hline gram $(\mathrm{g})$ & 0.03527 & ounce, avoirdupois (oz) \\
\hline kilogram (kg) & 2.205 & pound avoirdupois (lb) \\
\hline \multicolumn{3}{|c|}{ Density } \\
\hline kilogram per cubic meter $\left(\mathrm{kg} / \mathrm{m}^{3}\right)$ & 0.06242 & pound per cubic foot $\left(\mathrm{lb} / \mathrm{ft}^{3}\right)$ \\
\hline gram per cubic centimeter $\left(\mathrm{g} / \mathrm{cm}^{3}\right)$ & 62.4220 & pound per cubic foot $\left(\mathrm{lb} / \mathrm{ft}^{3}\right)$ \\
\hline \multicolumn{3}{|c|}{ Specific capacity } \\
\hline liter per second per meter $([\mathrm{L} / \mathrm{s}] / \mathrm{m})$ & 4.831 & gallon per minute per foot $([\mathrm{gal} / \mathrm{min}] / \mathrm{ft})$ \\
\hline \multicolumn{3}{|c|}{ Hydraulic conductivity } \\
\hline meter per day $(\mathrm{m} / \mathrm{d})$ & 3.281 & foot per day $(\mathrm{ft} / \mathrm{d})$ \\
\hline \multicolumn{3}{|c|}{ Transmissivity } \\
\hline meter squared per day $\left(\mathrm{m}^{2} / \mathrm{d}\right)$ & 10.76 & foot squared per day $\left(\mathrm{ft}^{2} / \mathrm{d}\right)$ \\
\hline
\end{tabular}

Temperature in degrees Celsius $\left({ }^{\circ} \mathrm{C}\right)$ may be converted to degrees Fahrenheit $\left({ }^{\circ} \mathrm{F}\right)$ as ${ }^{\circ} \mathrm{F}=\left(1.8 \times{ }^{\circ} \mathrm{C}\right)+32$. 
U.S. customary units to International System of Units

\begin{tabular}{|c|c|c|}
\hline Multiply & By & To obtain \\
\hline \multicolumn{3}{|c|}{ Length } \\
\hline inch (in.) & 2.54 & centimeter $(\mathrm{cm})$ \\
\hline foot $(\mathrm{ft})$ & 0.3048 & meter $(\mathrm{m})$ \\
\hline \multicolumn{3}{|c|}{ Volume } \\
\hline cubic foot $\left(\mathrm{ft}^{3}\right)$ & 0.02832 & cubic meter $\left(\mathrm{m}^{3}\right)$ \\
\hline \multicolumn{3}{|c|}{ Flow rate } \\
\hline cubic foot per second $\left(\mathrm{ft}^{3} / \mathrm{s}\right)$ & 0.02832 & cubic meter per second $\left(\mathrm{m}^{3} / \mathrm{s}\right)$ \\
\hline \multicolumn{3}{|c|}{ Pressure } \\
\hline pound per square inch $\left(\mathrm{lb} / \mathrm{in}^{2}\right)$ & 6.895 & kilopascal $(\mathrm{kPa})$ \\
\hline
\end{tabular}

\section{Abbreviations}

\begin{tabular}{|c|c|}
\hline $\begin{array}{l}\text { AFA } \\
\text { BNL }\end{array}$ & $\begin{array}{l}\text { cyanobacterium Aphanizomenon flos-aquae } \\
\text { benthic nepheloid layer }\end{array}$ \\
\hline cf. & confer (a species that closely matches another species) \\
\hline $\mathrm{D}$ & particle size \\
\hline DO & dissolved oxygen \\
\hline $\mathrm{DOC}$ & dissolved organic carbon \\
\hline e.i. & early instar \\
\hline EPA & U.S. Environmental Protection Agency \\
\hline EPS & extra-cellular polymeric substances \\
\hline $\mathrm{J}$ & diffusive benthic flux in milligrams per square meter per day \\
\hline $\mathrm{kg} \mathrm{d}^{-1}$ & kilogram per day \\
\hline $\mathrm{kg} \mathrm{m}^{-3}$ & kilogram per cubic meter \\
\hline$\mu \mathrm{g} \mathrm{cm}^{-2}$ & microgram per square centimeter \\
\hline$m^{2} d^{-1}$ & square meter per day \\
\hline$m^{3} d^{-1}$ & cubic meter per day \\
\hline$\mu S \mathrm{~cm}^{-1}$ & microsiemen per centimeter \\
\hline $\mathrm{mg} \mathrm{L}^{-1}$ & milligram per liter \\
\hline $\mathrm{mg} \mathrm{m}^{-2} \mathrm{~d}^{-1}$ & milligram per square meter per day \\
\hline $\mathrm{mg} \mathrm{m}^{-2} \mathrm{~s}^{-1}$ & milligram per square meter per second \\
\hline $\mathrm{mm} \mathrm{s}^{-1}$ & millimeter per second \\
\hline MSF & mass settling flux \\
\hline na & not available \\
\hline nd & nondetectable value \\
\hline nr. & near (taxonomically) \\
\hline ORP & oxidation-reduction potential \\
\hline$\rho$ & density \\
\hline Reclamation & Bureau of Reclamation \\
\hline SD & standard deviation \\
\hline sp. & species \\
\hline SPMC & suspended particulate matter concentration \\
\hline spp. & species (plural) \\
\hline SRP & dissolved (soluble) reactive phosphate \\
\hline UKL & Upper Klamath Lake, Oregon \\
\hline USGS & U.S. Geological Survey \\
\hline Ws & settling velocity \\
\hline
\end{tabular}




\section{Benthic Processes Affecting Contaminant Transport in Upper Klamath Lake, Oregon}

fBy James S. Kuwabara, Brent R. Topping, James L. Carter, Francis Parchaso, Rick A. Carlson, ${ }^{1}$ Stephen V. Fend, Natalie Stauffer-Olsen, ${ }^{2}$ Andrew J. Manning, ${ }^{3}$ and Jennie M. Land ${ }^{1}$

\section{Executive Summary}

Multiple sampling trips during calendar years 2013 through 2015 were coordinated to provide measurements of interdependent benthic processes that potentially affect contaminant transport in Upper Klamath Lake (UKL), Oregon. The measurements were motivated by recognition that such internal processes (for example, solute benthic flux, bioturbation and solute efflux by benthic invertebrates, and physical groundwater-surface water interactions) were not integrated into existing management models for UKL. Up until 2013, all of the benthic-flux studies generally had been limited spatially to a number of sites in the northern part of UKL and limited temporally to 2-3 samplings per year. All of the benthic invertebrate studies also had been limited to the northern part of the lake; however, intensive temporal (weekly) studies had previously been completed independent of benthic-flux studies. Therefore, knowledge of both the spatial and temporal variability in benthic flux and benthic invertebrate distributions for the entire lake was lacking. To address these limitations, we completed a lakewide spatial study during 2013 and a coordinated temporal study with weekly sampling of benthic flux and benthic invertebrates during 2014. Field design of the spatially focused study in 2013 involved 21 sites sampled three times as the summer cyanobacterial bloom developed (that is, May 23, June 13, and July 3,2013 ). Results of the 27-week, temporally focused study of one site in 2014 were summarized and partitioned into three periods (referred to herein as pre-bloom, bloom and post-bloom periods), each period involving 9 weeks of profiler deployments, water column and benthic sampling. Partitioning of the pre-bloom, bloom, and post-bloom periods were based on water-column chlorophyll concentrations and involved the following date intervals, respectively: April 15 through June 10, June 17 through August 13, and August 20 through October 16, 2014.

To examine dissolved-solute (0.2-micrometer $[\mu \mathrm{m}]$ filtered) benthic flux, sets of nonmetallic pore-water profilers (U.S. Patent 8,051,727 B1) were deployed. In 2013, the deployment of profilers at 21 UKL sites occurred at the beginning of the annual cyanobacterial bloom of Aphanizomenon flosaquae (AFA), in the middle of the bloom period, and at the peak of the bloom. Coordinated benthic invertebrate collections also were made. Based on results from 2013, weekly deployments of profilers and collection of benthic invertebrate samples from late spring to early autumn were used to estimate temporal trends in solute flux and benthic invertebrate densities. Estimates of nutrient efflux by benthic invertebrates were determined in the spring and autumn from 2011 through 2013 and three times (spring, summer, and autumn) in 2015. This work extends UKL studies that began in 2006 to quantify

\footnotetext{
${ }^{1}$ Bureau of Reclamation

${ }^{2}$ University of California, Berkeley, College of Natural Resources

${ }^{3}$ Plymouth University, School of Marine Science and Engineering
} 
the importance of benthic solute sources in the lake. In 2015, piezometers and thermistor sets were deployed to quantify potential groundwater exchange with the lake water column.

Analysis of the 2013 soluble reactive phosphorus (SRP) benthic flux indicated no effect of location (lake region), habitat, or sampling period, and the average lakewide flux values were consistent with earlier studies that had been confined to the northern region of UKL and adjacent wetlands. The 2014 study therefore focused on estimating temporal trends at a site within Ball Bay. During both 2013 and 2014 field studies, fluxes of macronutrients (soluble reactive phosphorus (SRP) and ammonia) and micronutrients (iron $[\mathrm{Fe}]$ and manganese $[\mathrm{Mn}]$ ) were consistently positive and increased prior to the initial AFA bloom, varied or lagged with water-column chlorophyll during the summer bloom period, then decreased after the cyanobacterial blooms, only to rebound toward pre-bloom conditions in the final weeks of sampling. These four solutes exhibited benthic loads greater than maximum riverine loads estimated during the spring and early summers of 2013 and 2014. However, consistently detectable concentrations for all four solutes provide no evidence that they consistently serve as the limiting nutrient for primary production in the lake. In contrast to the four solutes (SRP, ammonia, Fe, and $\mathrm{Mn}$ ), benthic fluxes of dissolved arsenic (As) were both negative and positive (that is, the lakebed currently serves as both a source and a sink for dissolved As, depending on season). In a further contrast with SRP, ammonia, dissolved Fe, and Mn, dissolved-As riverine loads to UKL were of similar magnitude to benthic loads. A negative relationship between dissolved-As flux and water-column As over the 2014 temporal study provides a potential advantage for the management of water-quality in contrast to solutes, like SRP or ammonia, with consistently positive flux.

The mean total benthic invertebrate density during 2013 was 12,610 individuals per square meter $(n=63)$. Although benthic invertebrate density did not change over the study period, it was higher in littoral habitats than open-lake or trench habitats and higher in the northern region compared to the central or southern regions of UKL. Mean total benthic invertebrate density during 2014 was 19,726 individuals $\mathrm{m}^{-2}(\mathrm{n}=27)$. Density during the pre-bloom and bloom periods of April 15 to August 13, 2014 (the first two thirds of the 2014 sampling period), were similar to 2013. However, benthic invertebrate density more than doubled during the latter one-third of the study, that is, the post-bloom period between August 20 to October 16, 2014. Oligochaeta, Chironomidae and Hirudinea represented well over 90 percent of the benthic fauna; Oligochaeta were twice as abundant as Chironomidae or Hirudinea, the latter two of which were similar in density.

Benthic invertebrates may enhance dissolved-nutrient (or toxicant) transport across the sediment-water interface by (1) modifying diffusion-layer thicknesses and permeability through bioturbation, (2) enhancing advective flow across the interface through bioirrigation, and (3) excreting or expelling dissolved or particulate solutes directly into the overlying water column (Boudreau and Jorgensen, 2001). We evaluated SRP efflux via excretion for approximately 15 different major taxa in UKL. Once these measures were scaled, it was evident that benthic invertebrates potentially contribute approximately 1.5 times the amount of SRP to the water column of Upper Klamath Lake as diffusive SRP flux alone, measured in profiler deployments.

Sets of piezometers and temperature loggers were deployed in UKL to obtain estimates of vertical advective solute flux. The pressure transducer installations, within the piezometers, did not perform as designed, rendering the head gradient data unreliable. However, in terms of future research, this field work did demonstrate the feasibility of collecting vertical gradient data with piezometer deployments. Advective flux estimates herein are based solely on heat-flow modeling based on temperature data from four lake sites, without use of transducer data. Given the magnitudes (both positive or negative) of the heat-transfer fluxes for SRP, relative to diffusive-flux and macroinvertebrate efflux measurements (all positive but spanning the same orders of magnitude), further examination of 
solute advective flux is recommended as a potential transport process to integrate into existing waterquality (for example, Total Maximum Daily Load [TMDL]) models.

As a complement to the biogeochemical focus of this study, initial analyses of suspendedparticle (floc) characteristics and settling velocities from the water column were derived near the surface and lakebed at two UKL sites. To better understand changing particle characteristics during the AFAbloom period, suspended particles were examined in 2015 using a LabSFLOC (LF), which is a Laboratory Spectral Flocculation Characteristics version of an In-Situ Settling Velocity instrument (INSSEV-LF). Particle characteristics and settling velocities were analyzed from the water column near the surface (sample $d p \_10$ ) and lakebed (sample $d p \_90$ ) at two lake sites (open-lake site ML and littoral site LS01). The term "floc" refers herein to suspended particles that may aggregate or disaggregate to change in size, composition, and settling velocity.

During pre-bloom (May) conditions, where maximum suspended particulate matter concentration (SPMC) was 140 milligrams per liter $\left(\mathrm{mg} \mathrm{L}^{-1}\right)$ at site $\mathrm{ML}$, the average floc sizes were small, not exceeding $122 \mu \mathrm{m}$ at ML or LS01. In the July bloom, a high SPMC of $316 \mathrm{mg} \mathrm{L}^{-1}$ was now observed at site LS01 in close proximity to the bed, where $\mathrm{D}_{\text {mean }}$ peaked at $305 \mu \mathrm{m}$, and the corresponding $\mathrm{Ws}_{\text {mean }}$ was 3.9 millimeters per second $\left(\mathrm{mm} \mathrm{s}^{-1}\right)$. The high near-bed SPMC $\left(828 \mathrm{mg} \mathrm{L}^{-1}\right)$ experienced during post-bloom October 2015 at LS01 formed a benthic nepheloid layer (BNL) above the lake's bed. Numerous low density, fast settling macrofloc-sized organic aggregates $(\mathrm{D}>160 \mu \mathrm{m})$ were observed (some up to $1 \mathrm{~mm}$ in size) near bed at LS01 both during the bloom and post-bloom conditions; many of these flocs displayed fibrous organic structures. In terms of mass settling fluxes, the post-bloom BNL produced a total MSF of 4,139 milligrams per square meter per second $\left(\mathrm{mg} \mathrm{m}^{-2} \mathrm{~s}^{-1}\right)$ (92.1 percent of MSF credited to the macrofloc-sized organic aggregates/cyanobacterial colonies); that was nearly three times the corresponding near-bed settling flux observed during the July 2015 bloom and 360 times greater than the pre-bloom conditions from May 2015 (98.8 percent and 14 percent of MSF credited to the macrofloc-sized fractions for those respective months). Such changes in the nearbed settling flux demonstrate the highly significant seasonal effects that the AFA bloom has on the floc depositional fluxes in UKL and highlights the importance of seasonal monitoring of these conditions in order to correctly parameterize the wide range in depositional characteristics and floc properties measured throughout UKL.

Collectively, floc populations observed within UKL demonstrated a wide range in settling velocity (Ws) for a given particle size, D. Similarly, a given settling velocity was not associated with a specific particle size. This variability in particle characteristics and properties indicates the influence of varying floc effective density and its effect on mass and mass settling fluxes (MSF). The use of instruments, such as the INSSEV-LF, enables measuring the variability of settling velocity and its relation to particle density and size.

\section{Introduction}

\section{Potential Management Implications}

Harmful algal blooms, like those annually encountered in Upper Klamath Lake (UKL, also referred to as "the lake"), Oregon, have become one of the most challenging water-quality issues facing the world's freshwater ecosystems (Brooks and others, 2016). Management goals of maintaining or restoring water quality and hence endangered fisheries resources in Upper Klamath Lake and the downstream Klamath River Basin are dependent on the transport of essential nutrients and toxicants through benthic and pelagic food webs. The autotrophic and heterotrophic base of those food webs, from which trophic transfer begins, is dependent on sediment and water quality. In order to meet water- 
quality objectives for the lake (for example, to reduce the impact of nutrient cycling on eutrophication and endangered fish populations in the lake), an understanding of the processes governing nutrient transport and distribution is required to help explain temporal and spatial trends in benthic and pelagic community composition. The structure and abundance of these communities are in turn linked to nutrient accumulation and remobilization within the lake as well as solute loads from upstream. In hypereutrophic Upper Klamath Lake, predominance of the nitrogen-fixing cyanophyte Aphanizomenon flos-aquae (AFA) suggests that a factor other than nitrogen regulates phytoplankton biomass. With the recognition that benthic processes (internal cycling) of contaminants may play an important role in solute transport within the lake (Wood and others, 2013; Wherry and others, 2015), this study focuses on the benthic nutrient and trace metal sources from the lakebed that may be significant relative to potentially regulated allochthonous sources. In addition to phosphorus, we examine the benthic flux of dissolved inorganic nitrogen species (nitrate, nitrite, and ammonia) as well as dissolved micronutrient fluxes from the lake sediments. Spatial and temporal trends in these benthic solute sources or sinks should also be useful to resource managers who are interested in refining management (Total Maximum Daily Load [TMDL]) models that integrate benthic processes. Although the study focused on the biogeochemical flux of dissolved nutrients and trace elements, piezometer and temperature-logger deployments, as well as suspended-sediment characterizations in 2015, began to address the influence of physical processes on nutrient cycling within and through the lake. This complementary information is envisioned as potentially necessary for the development of numerical models of nutrient transport. Information provided herein is intended to provide internal solute-loading information for such models and to indicate reasonable expectations when evaluating strategies for solute-load allocations or habitat restoration.

\section{Background}

In hypereutrophic Upper Klamath Lake (UKL), Oregon (table 1; fig. 1), organic carbon generated by massive cyanophyte blooms that is not transported out of the lake ultimately settles to the bed of the lake or, to some extent, wetland habitats and imposes a benthic demand for oxygen. Such a demand can pose an environmental stress for endangered fish populations (Wood and others, 2006). Although phosphorus (P) may typically serve as the limiting nutrient for those nitrogen-fixing cyanophytes, our previous lake studies indicated that internal loading of dissolved micronutrients (for example, iron and manganese) should also be further examined. We therefore present water-column and benthic-flux information for both macro- and micronutrients that may be pertinent to source management for the basin (U.S. Fish and Wildlife Service, Hatfield Restoration Program; http://www.fws.gov/klamathfallsfwo/ero/er.html). In recognition of increasing interest in arsenic transport through the lake and basin, fluxes for dissolved total arsenic are also presented. On a global scale, the imminent need for a better quantitative understanding of the interdependent effects of natural and anthropogenic factors on the likelihood and severity of harmful algal blooms, like those occurring annually in UKL, have been discussed and advocated (Brooks and others, 2016). 


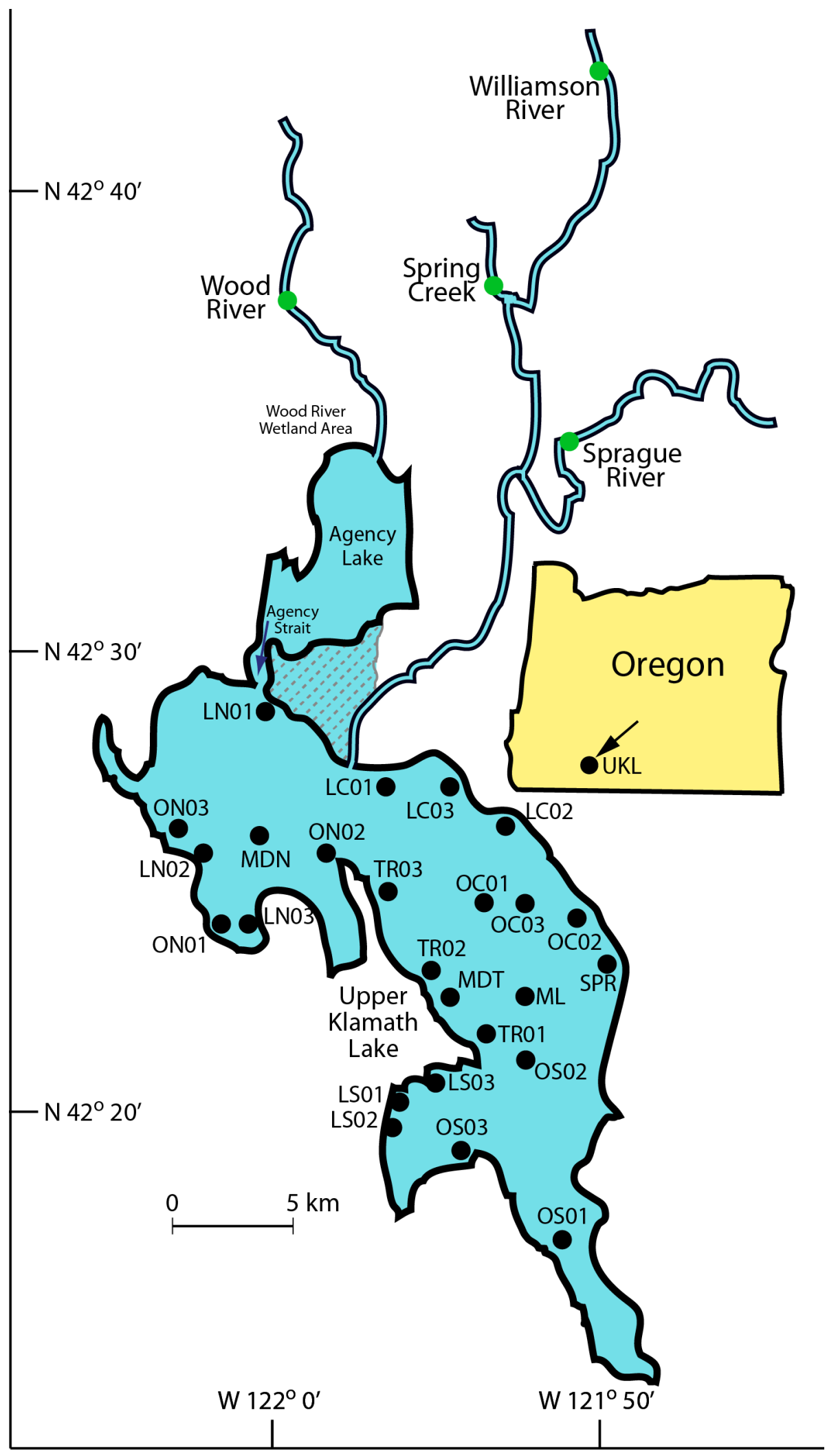

Figure 1. Map of Upper Klamath Lake and sampling sites for 2013, 2014, and 2015. 
During the early to mid-1900s, massive phytoplankton blooms dominated by Aphanizomenon flos-aquae (AFA) have occurred each summer in UKL. After buoyant AFA layers (scums) are concentrated by wind over the lake surface and cells senesce, biomass settles and water-column dissolved oxygen is depleted at the lakebed. Such hypoxia may affect the recruitment and survival of lake fauna, including zooplankton, benthic invertebrates, and endangered populations of the shortnose sucker (Chasmistes brevirostris) and Lost River sucker (Deltistes luxatus). Indeed, the sustainability of sucker populations is linked to the water quality in the lake, and to the nutrient sources that regulate the intensity of AFA blooms, and the succession of phytoplankton assemblages before and after those blooms. Of particular significance is the appearance of the non-nitrogen-fixing, hepatotoxin-producing cyanobacterium Microcystis aeruginosa (Kann, 2006). Though not abundant relative to AFA, $M$. aeruginosa has been consistently and more-ubiquitously detected in Upper Klamath Lake (Eldridge and others, 2014). Investigations on the sources and distributions of microcystin in Upper Klamath Lake continue by other collaborating U.S. Geological Survey (USGS) projects within the Ecosystems Mission Area and the Oregon Water Science Center.

Previous studies (Kuwabara and others, 2009; Kuwabara and others, 2012a) consistently indicated that problematic phytoplankton blooms are fueled by external and internal loads of particlereactive solutes (for example, ligands/anions like phosphorus as orthophosphate or metals like iron and manganese). As these solutes repartition and change in chemical speciation, benthic sources of these nutrients may play a major role in phytoplankton dynamics and succession (Kuwabara and others, 2009). Nonmetallic pore-water profilers (U.S. Patent 8,051,727 B1), designed and fabricated for previous studies of Upper Klamath Lake (Kuwabara and others, 2009), were successfully deployed at a total of 21 lake sites that include three habitat types (littoral, open-lake, and a western trench feature), as well as three area-equivalent geographic types (northern, central, and southern) that represent lake regions near tributary inputs in the north and outflows through the dam in the south.

Furthermore, abiotic internal loads can be significantly augmented by solute efflux and bioturbation by benthic invertebrate assemblages in the lake that phenologically change in composition throughout the annual cyanobacterial bloom cycle in the lake. Benthic invertebrates (for example, worms, insects, mollusks) are an integral component of lake ecosystems. They are composed of all higher trophic levels (that is, above primary producers) and include several functional feeding groups, such as filterers, grazers, deposit feeders, piercers, and engulfers. They also represent an important food resource for fishes, birds, and some mammals. Benthic invertebrates directly cycle nutrients between the sediments of lakes and the water column through normal metabolic processes and indirectly influence diffusive and advective flux of solutes through their behavioral bioturbation of lakebed sediments.

Therefore, in agreement with Miller and Tash (1967), "It is imperative to know the extent to which nutrients in the sediments can interchange with the overlying water." This study quantifies benthic processes that contribute to that interchange.

\section{Objectives}

In support of science-based restoration/management strategies for Upper Klamath Lake, adjacent wetlands, and downstream ecosystems, this study provides measurements of biotic and abiotic benthic fluxes of dissolved macronutrients and trace elements between the lakebed and overlying water column. The spatial and temporal distribution of benthic invertebrate assemblages, solute efflux from major species within those assemblages, benthic-chlorophyll and water-column solute concentrations were also analyzed to augment solute-flux results. The work addresses two hypotheses of imminent management relevance. First, some of the macronutrients (for example, soluble reactive phosphorus [SRP] and ammonia) and many of the trace elements (for example, cadmium, copper, iron, manganese, 
nickel, and zinc) are chemically reactive and adsorb to biotic and abiotic surfaces. We hypothesize that benthic sources, deemed significant for certain solutes in previous studies relative to other sources, could be quantified in a way consistent with incorporation into existing water-quality management (for example, Total Maximum Daily Load) models. Given the paucity of trace-metal and benthic invertebrate information for this or any other part of the Klamath River Basin, we provide trace-element benthic flux for Upper Klamath Lake (including dissolved-arsenic water-column concentrations and benthic fluxes), as well as benthic invertebrate solute efflux measurement. This study clearly focused on biogeochemical processes near the sediment-water interface that may affect solute transport and phytoplankton dynamics in the lake. However, in recognition of potential physical processes that may also be of management relevance, (1) transducers and temperature loggers were deployed to examine advective fluxes across that interface, and (2) suspended particles were examined in 2015 using an InSitu Settling Velocity Instrument (INSSEV-LF) to better understand changing particle characteristics during the AFA-bloom period at an open-lake and littoral zone site near the surface and lakebed.

\section{Results and Discussion}

\section{3-Spatial Variability Study}

Field design of the spatially focused study in 2013 involved 21 sites sampled three times as the summer cyanobacterial bloom developed (that is, May 23, June 13, and July 3, 2013). In addition, preliminary samples were collected at only two sites during a reconnaissance trip on May 1, 2013, to test and refine experimental protocols for the subsequent sampling trips. The 21 lake sites were selected among three geographic partitions and three habitats (see "Methods" section). Tables presenting results from the 2013 sampling effort have shaded blocks of rows for results from June 13, 2013, to distinguish between sampling dates (for example, tables 2-8).

\section{Ancillary Parameters in 2013}

Measurements of ancillary water-column parameters (for example, temperature, specific conductivity, $\mathrm{pH}$, and dissolved oxygen), collected by vertical sonde deployments at the profiler deployment sites, are provided to establish the basic physical and chemical context to assist in interpreting results for solute benthic fluxes. Except for the three trench sites (6.0-14.2 meters [m] depth) and the mid-lake north (MDN) site ( 4 $\mathrm{m}$ depth), the sites where profilers were deployed were shallow ( $<3 \mathrm{~m}$ depth), with minimal haloclines or thermoclines. In fact, the littoral-zone sites (that is, site names beginning with "L") were $<2 \mathrm{~m}$ depth. Specific conductivity values varied over a narrow range (94 to 460 microsiemens per centimeter $\left[\mu \mathrm{S} \mathrm{cm}^{-1}\right]$ ), with an expected trend of lowest values during the pre-bloom and early-bloom deployments as snow melt diluted lake waters (May through June 2013) and elevated values during the later bloom samplings as lake waters evaporated and water elevations decreased (July 2013). Consistent water-temperature ranges reflected seasonal, increasing airtemperature patterns affecting the water column at all sites during our 2013 sampling period (table 2; 11.3 to $11.9^{\circ} \mathrm{C}$ on May 1,2013 , compared to 18.4 to $26.5^{\circ} \mathrm{C}$ on July 3, 2013, near the peak of the annual AFA bloom). Observed seasonal ranges are consistent with previous and ongoing monitoring of Upper Klamath Lake by Wood and others (2006, 2013).

Dissolved oxygen (DO) decreased with depth in 57 of 60 water column profiles (table 2). Furthermore, the mean difference between surface- and bottom-water percent DO saturation increased from May through July $(-9.8 \pm 19.7$ percent $[\mathrm{n}=21],-19.9 \pm 25.1$ percent $[\mathrm{n}=21]$, and $-62.9 \pm 34.2$ percent [n=17] for May 23, June 13, and July 3, 2013, respectively). This temporal increase in the 
difference between surface- and bottom-water DO might be expected as the initial AFA bloom develops. There are a number of mechanisms that could contribute to this DO depth difference. First, enhanced net photosynthesis near the surface as the bloom progresses increases DO in the photic zone. For example, the percent DO saturation increase between the May 23 and July 3 deployments in surface waters was $23.3 \pm 34.7$ percent $(n=16$ sites). Second, near the bottom, organic matter settles from the water column to the lakebed, increasing benthic-oxygen demand and decreasing bottom-water DO. Water-column respiration near the bottom also decreases DO. Percent DO saturation in bottom waters decreased $(-32.6 \pm 32.5$ percent, $n=16)$ between the May 23 and July 3 deployments. Enhancing the aforementioned processes is the effect of thermal stratification as the summer progresses. Kann and Welch (2005) observed increasing differences between surface- and bottom-water DO concentrations in UKL during midsummer (July and August 1990 through 2001) with increasing water-column stability (that is, stratification dependent on wind speed). However, examining data between 1990 and 2004, Wood and others (2006) did not observe a significant relationship between wind speed and differences between minimum and maximum DO in the UKL water column.

For $\mathrm{pH}$, a gradual rise was observed through the sampling dates; $\mathrm{pH}$ varied between 6.8 and 7.1 on May 1, 2013 (prior to the bloom), and varied between 8.2 and 10.3 on July 3, 2013. With 2 exceptions out of 40, $\mathrm{pH}$ was $>9$ on July 3, 2013 (table 2). The maximum $\mathrm{pH}, 10.3$, was at site OC03 and measured at 0935 PST, so even higher $\mathrm{pH}$ values may be expected as solar energy increases later in the day and phytoplankton accelerate their removal of dissolved inorganic carbon from the water column (Wood and others, 2006). There are many biogeochemical and toxicological implications owing to elevated $\mathrm{pH}$. For example, Falter and Cech (1991) reported a maximum $\mathrm{pH}$ tolerance of $9.55 \pm 0.43$ for shortnose suckers, while Meyer and Hansen (2002) reported no toxicological effect of $\mathrm{pH}<10$ on multiple life stages of Lost River suckers. In 2013, $\mathrm{pH}>10$ was only observed at seven sites, all on July 3, the final 2013 sampling date near the initial AFA bloom peak (table 2). Morace (2007) also reported multiple $\mathrm{pH}$ measurements $>10$ in UKL during the summer AFA-bloom period. Second, as $\mathrm{pH}$ increases, the chemical speciation and partitioning of biologically reactive solutes are significantly affected. For example, as $\mathrm{pH}$ rises above the negative logarithm of the acid dissociation constant for the ammonium ion (9.3), uncharged and toxic ammonia $\left(\mathrm{NH}_{3}\right)$ becomes more thermodynamically stable relative to the ammonium ion (Arillo and others, 1981; Randall and Tsui, 2002). Third, as pH elevates, adsorbed anions (for example, orthophosphate) repartition from particulate to the more biologically available, dissolved phase (Sigg and Stumm, 1981; Goldberg, 1985; Fisher and Wood, 2001). Fourth, in an oxic environment, micronutrients (for example, iron, manganese, and copper) become less soluble (and hence less bioavailable to primary producers) because precipitates and adsorbed forms become more stable (Hogfeldt, 1982; Kuwabara and others, 1986), thereby decreasing uncomplexed (that is, more bioavailable) metal forms.

\section{Benthic Flux of Macronutrients in 2013}

Benthic fluxes (table 3), calculated using Fick's law (see "Methods" section), specifically represent a diffusive solute flux across the sediment-water interface and may therefore underestimate total benthic sources by all additional processes (for example, benthic invertebrate efflux, bioturbation, and solute advection) when pore-water concentrations are consistently greater than overlying watercolumn concentrations. Among macronutrients examined in this study, soluble (0.2-micrometer $[\mu \mathrm{m}]$ filtered) reactive phosphorus (that is, a biologically available form of dissolved phosphorus, SRP) is an extremely particle-reactive solute as $\mathrm{pH}$ becomes elevated. That is, SRP can form stable surface complexes on a variety of mineral and biotic surfaces (Sigg and Stumm, 1981; Goldberg, 1985; Kuwabara and others, 1986; Ruttenberg, 1992). Particulate P can be transported through the lake to the 
down-gradient river basin or may settle in the lake and accumulate in the bottom sediments. Various biogeochemical processes related to changes in acid-base and redox (oxidation-reduction) chemistry near the sediment-water interface can recycle this $\mathrm{P}$ and generate a benthic flux of bioavailable $\mathrm{P}$ that may far exceed external sources (Kuwabara and others, 2003). Because the dominant phytoplankton species, AFA, is a nitrogen-fixing cyanophyte, it is reasonable to assume that a nutrient other than nitrogen (for example, phosphorus, iron, or manganese) may serve as the stimulatory nutrient to initiate the annual cyanobacterial bloom (Istvánovics, 2008).

In this report, concentration units for dissolved nutrients are in terms of the element rather than the associated molecule, with the exception of silica as $\mathrm{SiO}_{2}$. For example, the concentration unit specified herein for dissolved ammonia is milligrams of nitrogen per liter $\left(\mathrm{mg}_{-} \mathrm{N} \mathrm{L}^{-1}\right)$, as opposed to an ammonia species.

As previously reported for Upper Klamath Lake (Kuwabara and others, 2009; Kuwabara and others, 2012a), SRP benthic flux as estimated from 2013 profiler deployments was consistently positive (table 3), that is, from the lakebed to the overlying water column, but was highly variable in magnitude with a mean of $4.28 \pm 4.84$ milligrams of phosphorus per square meter per day $\left(\mathrm{mg}^{-\mathrm{P} \mathrm{m}} \mathrm{m}^{-2} \mathrm{~d}^{-1}\right)(\mathrm{n}=65$, range $=0.13$ to $33.27 \mathrm{mg}-\mathrm{P} \mathrm{m}^{-2} \mathrm{~d}^{-1}$ ). This represents an areally averaged SRP (as P) load to the lake water column of $856 \pm 968$ kilograms per day $\left(\mathrm{kg} \mathrm{d}^{-1}\right)\left(\mathrm{n}=65\right.$, range $=26$ to $\left.6,650 \mathrm{~kg} \mathrm{~d}^{-1}\right)$, assuming a lake area of 200 square kilometers $\left(\mathrm{km}^{2}\right)$ (Kuwabara and others, 2009). By comparison, estimates of SRP (as P) loads from the inlet tributaries, sampled in the spring and early summer of 2013 and 2014 (table 4) varied from 115 to $154 \mathrm{~kg} \mathrm{~d}^{-1}$, bracketed by the SRP benthic-flux range. Statistical analysis of the SRP benthic-flux measurements indicated no effect of location (lake region), habitat, or sampling period. Furthermore, the average lakewide flux values were consistent with earlier studies that had been confined to the northern region of the lake and adjacent wetlands (Kuwabara and others, 2009; Kuwabara and others, 2012a). Therefore, the subsequent 2014 experimental design for a temporal study, weekly resolution, focused around site ON01 within Ball Bay because of (1) representative SRP fluxes in 2013, (2) representative benthic invertebrate communities, (3) accessibility during periods of high winds within Ball Bay, and (4) focused allocation of available resources to optimize temporal resolution of benthic solute source measurements.

Benthic flux of ammonia, particularly at elevated $\mathrm{pH}$ in the overlying water column, has toxicological implications for endangered sucker populations (Meyer and Hansen, 2002). Similar to SRP, ammonia benthic flux was consistently positive, indicating (1) a consistent benthic source of ammonia to the lake water column and (2) potentially elevated (relative to the water column) solute concentrations close to the sediment-water interface, where the endangered suckers presumably feed, and also potentially elevated when the water column is thermally stratified. In most areas of UKL, such thermal stratification, when it occurs, does not persist overnight, but in deeper parts of the lake, the water column can remain stratified for a few days at a time (Wood and others, 2006). Martin and Saiki (1999) determined in their fish-cage studies of the Lost River sucker (Deltistes luxatus) that elevated concentrations of un-ionized ammonia may be contributing to the precipitous decline of sucker populations in Upper Klamath Lake, although depletion of dissolved oxygen in the water column (a factor that covaries with ammonia) exerted an even stronger influence on sucker mortality. The correlations between DO and tabulated ammonia in 2013 and 2014 were $-0.35(\mathrm{p}<0.001, \mathrm{n}=77)$ and $-0.46(\mathrm{p}<0.05, \mathrm{n}=27)$, respectively. Ammonia benthic flux was $10.73 \pm 8.07$ milligrams nitrogen per square meter per day $\left(\mathrm{mg}-\mathrm{N} \mathrm{m}^{-2} \mathrm{~d}^{-1}\right.$ (range $=1.93$ to $\left.42.67, \mathrm{n}=65\right)$. This represents an areally averaged ammonia (as N) load to the lake of $2,150 \pm 1,610 \mathrm{~kg} \mathrm{~d}^{-1}$ (table 3). By comparison, estimates of ammonia loads from the inlet tributaries ranged from 9 to $326 \mathrm{~kg} \mathrm{~d}^{-1}$, one to three orders of magnitude lower than benthic-flux measurements. In the wetlands adjacent to the northern boundary of the lake, 
Kuwabara and others (2012a) observed a positive correlation between dissolved-ammonia benthic flux and water-column dissolved ammonia, primarily affected by elevated values of both parameters during post-bloom conditions. That ammonia correlation was not present in the 2013 lake data, as elevated water-column ammonia concentrations were only observed in the final sampling (July 3, 2013), when the bloom began its transition to senescence. In contrast to SRP and ammonia, no positive benthic fluxes were observed for nitrate. This is consistent with previously published nitrate fluxes for Upper Klamath Lake (Kuwabara and others, 2009; Kuwabara, 2012a). Nitrate flux was $-0.55 \pm 2.34 \mathrm{mg}-\mathrm{N} \mathrm{m}^{-2}$ $\mathrm{d}^{-1}$ (range $=-12.42$ to $0.00 \mathrm{mg}-\mathrm{N} \mathrm{m}^{-2} \mathrm{~d}^{-1}, \mathrm{n}=65$; table 3 ). This represents an areally averaged nitrate (as N) load to the lake of between $-2,480$ to $0 \mathrm{~kg} \mathrm{~d}^{-1}$.

A microscopic examination of surficial lakebed sediments indicates an abundance of both pennate and centric diatom frustules. Prior to the annual summer cyanobacterial bloom in the lake, the water column is typically dominated by diatoms that require a source of dissolved silica. Similar to SRP and ammonia, benthic fluxes for dissolved silica were consistently positive (that is, a benthic source to the lake water column). The mean silica flux was $108 \pm 84 \mathrm{mg}-\mathrm{SiO}_{2} \mathrm{~m}^{-2} \mathrm{~d}^{-1}$ (range $=16$ to $579 \mathrm{mg}-\mathrm{SiO}_{2}$ $\mathrm{m}^{-2} \mathrm{~d}^{-1}, \mathrm{n}=61$ ). This represents an areally averaged silica $\left(\right.$ as $\left.\mathrm{SiO}_{2}\right)$ load to the lake of $21,600 \pm 16,800$ $\mathrm{kg} \mathrm{d}^{-1}$. By comparison, estimates for inlet tributary loads for dissolved silica measured in the spring and early summer of 2013 and 2014 were between 72,500 to 114,600 $\mathrm{kg} \mathrm{d}^{-1}$ (mean of 90,600 $\pm 15,700 \mathrm{~kg}$ $\mathrm{d}^{-1}, \mathrm{n}=6$ ); hence, there is a significant tributary source of dissolved silica to the lake water column relative to the lakebed (table 4 ).

Similar to nitrate, benthic flux of dissolved organic carbon (DOC) was often negative (that is, the solute was consumed by the lakebed), particularly during the final sampling in July 2013 (table 3). However, DOC flux varied between -5.17 and $2.15 \mathrm{mg}-\mathrm{C} \mathrm{m}^{-2} \mathrm{~d}^{-1}$, with a mean of $-0.47 \pm 1.24 \mathrm{mg}-\mathrm{C}$ $\mathrm{m}^{-2} \mathrm{~d}^{-1}(\mathrm{n}=65)$. That is, the lakebed served as both a source and a sink for DOC, representing an areally averaged DOC (as C) load to the lake of between $-1,030$ to $430 \mathrm{~kg} \mathrm{~d}^{-1}\left(-94 \pm 248 \mathrm{~kg} \mathrm{~d}^{-1}, \mathrm{n}=65\right.$ ). In an additional contrast to SRP and ammonia fluxes, inlet tributary loads for DOC measured in the spring and early summer of 2013 and 2014 were between 1,874 to $8,922 \mathrm{~kg} \mathrm{~d}^{-1}\left(4,322 \pm 2,525 \mathrm{~kg} \mathrm{~d}^{-1}, \mathrm{n}=7\right)$. As observed for dissolved silica, surface water sources of DOC to the lake were significant relative to the benthic sources.

\section{Dissolved (0.2- $\mu \mathrm{m}$ filtered) Nutrients in the Water Column in 2013}

Through the 2013 spatial study, soluble reactive phosphorus (SRP) varied between 0.02 and 0.36 mg-P per liter $\left(\mathrm{L}^{-1}\right)$ (overall mean of $0.07 \pm 0.06 \mathrm{mg}-\mathrm{P} \mathrm{L}^{-1}, \mathrm{n}=77$; table 5). The water-column SRP concentrations were generally low given that the detection limit was $0.007 \mathrm{mg}-\mathrm{P} \mathrm{L}^{-1}$, but all sites on all dates had detectable SRP. That is, SRP depletion was not observed in the lake water column. As previously noted (Kuwabara and others, 2009; Kuwabara and others, 2012a), this observation suggests the possibility of a limiting factor or factors other than, or in addition to, SRP. In contrast to seasonal nutrient trends typical of mono- or dimictic lakes (Wetzel, 2001), water-column solute concentrations in shallow lakes like Upper Klamath Lake are also subject to subseasonal variability in benthic interactions and rapid cycling through biomass. Spring and early summer SRP concentrations reported here are consistent with previous lake monitoring results (for example, Lindenberg and others, 2009; Hoilman and others, 2008; Kann, 2010). Near the AFA bloom peak on July 3, 2013, SRP did not exceed 0.13 mg-P L ${ }^{-1}$ at any of the 21 sampling sites, but a closer examination of temporal trends will be provided with the discussion of 2014 water-column nutrient concentrations.

Through the 2013 spatial study, dissolved-ammonia concentrations varied from $<0.007$ to 1.031 mg-N L ${ }^{-1}$ (overall mean of $0.13 \pm 0.22 \mathrm{mg}-\mathrm{N} \mathrm{L}^{-1}, \mathrm{n}=77$; table 5). In contrast to water-column SRP, seven samples were below the detection limit (that is, $<0.007 \mathrm{mg}_{-} \mathrm{N} \mathrm{L}^{-1}$ ), all during the June 13, 2013, 
sampling. Those seven samples also had undetectable dissolved nitrate (that is, $<0.01 \mathrm{mg}-\mathrm{N} \mathrm{L}{ }^{-1}$ ). The depletion of both ammonia and nitrate during the progression to a cyanobacterial peak has been observed at Lake Mendota, Wisconsin, and selects for nitrogen fixers like AFA (Beversdorf and others, 2013). In addition, dissolved-ammonia concentrations become a particular concern when elevated temperature and $\mathrm{pH}$ shift the speciation of ammonia toward the un-ionized form, $\mathrm{NH}_{3}{ }^{0}$. The effects of water temperature and $\mathrm{pH}$ on ammonia speciation can be calculated to determine un-ionized ammonia concentrations from tabulated ammonia concentrations (the sum of $\mathrm{NH}_{3}{ }^{0}$ and ionized $\mathrm{NH}_{4}{ }^{+}$) (Canadian Council of Ministers of the Environment, 2010). Potentially toxic water-column un-ionized ammonia concentrations above the median lethal concentration (LC50) for Lost River suckers $\left(0.45 \mathrm{mg}-\mathrm{N} \mathrm{L}^{-1}\right.$; Meyer and Hansen, 2002) were only observed at four sites (LS01 with 0.65 mg-N L ${ }^{-1}$, LS01 with 0.66 mg-N L ${ }^{-1}$, TR02 with $0.58 \mathrm{mg}-\mathrm{N} \mathrm{L}^{-1}$, and TR03 with $0.76 \mathrm{mg}-\mathrm{N} \mathrm{L}^{-1}$ ). All four exceedances were observed on July 3, 2013, the final 2013 sampling date near the initial AFA bloom peak (table 5). Morace (2007) also noted infrequent elevated un-ionized ammonia concentrations among 2,023 UKL samples collected between 1990 and 2006 (only 3 percent of samples greater than $0.53 \mathrm{mg}-\mathrm{N} \mathrm{L}^{-1}$ ). In comparison to suckers, Arillo and others (1981) observed sublethal dissolved-ammonia effects in both brain and liver of rainbow trout at much lower concentrations $\left(0.02 \mathrm{mg}-\mathrm{N} \mathrm{L}^{-1}\right.$ in un-ionized form $)$. In 2013, 22 of 77 water-column samples in UKL had dissolved un-ionized ammonia concentrations $>0.02$ mg-N L ${ }^{-1}$ (table 5). By contrast, dissolved ammonia was consistently $<0.02 \mathrm{mg}-\mathrm{N} \mathrm{L}^{-1}$ in tributary samples collected in the spring and early summer of 2013 and 2014, so even at the highest discharge to the lake measured during the present study in April 2013, riverine input for dissolved ammonia would be $326 \mathrm{~kg} \mathrm{~d}^{-1}$, considerably lower than the benthic ammonia loads determined in the 2013 spatial study $\left(2,150 \pm 1,610 \mathrm{~kg} \mathrm{~d}^{-1}\right.$, table 3).

Dissolved-nitrate concentrations were consistently low, with approximately one-third (that is, 25 of 77) water-column samples having undetectable concentrations $\left(<0.01 \mathrm{mg}^{-\mathrm{N} \mathrm{L}}{ }^{-1}\right)$. Concentrations

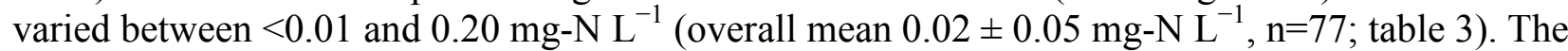
combination of low water-column and riverine nitrate concentrations and the absence of any positive nitrate fluxes suggest that ammonia rather than nitrate is the primary form of dissolved inorganic nitrogen (DIN) used by autotrophs in Upper Klamath Lake.

Similar to dissolved ammonia, dissolved silica increased as the initial AFA bloom neared its

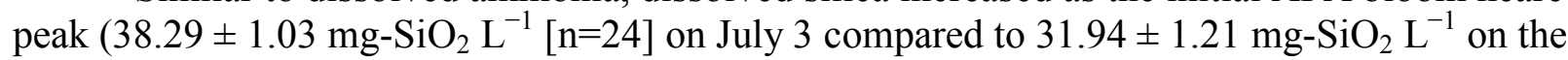
previous sampling date of June 13, 2013). Overall, silica concentrations in 2013 varied between 29.60 and $39.80 \mathrm{mg}_{-} \mathrm{SiO}_{2} \mathrm{~L}^{-1}$ (mean of $35.82 \pm 3.00 \mathrm{mg}-\mathrm{SiO}_{2} \mathrm{~L}^{-1}, \mathrm{n}=71$ ). Lake concentrations were lower than inlet-tributary concentrations along the Spring Creek, Sprague and Wood Rivers $(46.71 \pm 5.69 \mathrm{mg}-$ $\mathrm{SiO}_{2} \mathrm{~L}^{-1}, \mathrm{n}=9$ ) but higher than the Williamson River headwaters (downgradient of the marsh; $19.73 \pm$ $0.26 \mathrm{mg}-\mathrm{SiO}_{2} \mathrm{~L}^{-1}, \mathrm{n}=1$ site with two sample replicates; table 4).

Water-column concentrations in the lake for DOC in 2013 ranged from 3.58 to $6.88{\mathrm{mg}-\mathrm{C} \mathrm{L}^{-1}}^{-1}$ (overall mean of $4.44 \pm 0.86 \mathrm{mg}^{-\mathrm{C} \mathrm{L}^{-1}}, \mathrm{n}=74$ ). As seen with dissolved ammonia, the highest DOC concentrations occurred during the final sampling trip near the initial AFA bloom peak. For example,

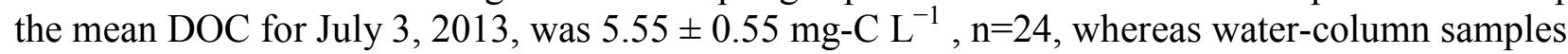
collected on the previous profiler deployment date of June 13, 2013, yielded a mean DOC of 4.07 \pm 0.21 $\mathrm{mg}-\mathrm{C} \mathrm{L}^{-1}, \mathrm{n}=24$.

\section{Benthic Flux of Trace Metals in 2013}

Information on the flux of trace elements across the sediment-water interface for any part of the Klamath River Basin is limited (Kuwabara and others, 2007; Kuwabara and others, 2012a). This study provides among the first dissolved trace metal benthic-flux estimates for a spatial network as broad as 
designed in 2013. In particular, to our knowledge, it is the first study to provide benthic-flux estimates for total dissolved arsenic (primarily as arsenate) for Upper Klamath Lake in response to recent, more stringent water-quality criteria for the State of Oregon (Atkins, 2016). In contrast to macronutrient fluxes (presented in units of $\mathrm{mg} \mathrm{m}^{-2} \mathrm{~d}^{-1}$ ), trace-element fluxes are provided in units of micrograms per square meter per day $\left(\mu \mathrm{g} \mathrm{m}^{-2} \mathrm{~d}^{-1}\right)$, owing to lower solute detection limits using inductively coupled plasma mass spectrometry (ICP-MS) relative to batch nutrient analyses. Like macronutrient fluxes, dissolved trace-element fluxes are presented in terms of the element rather than a dominant molecule (for example, vanadium $[\mathrm{V}]$ rather than vanadate).

Dissolved iron $(\mathrm{Fe})$ and manganese $(\mathrm{Mn})$, both essential micronutrients, exhibited consistently positive diffusive flux (that is, a consistent benthic solute source throughout the 2013 sampling period; table 6). In addition, the flux of these dissolved trace elements were at least two orders of magnitude higher than any of the other eight trace elements. Dissolved-iron benthic flux varied between 100 and $16,755 \mu \mathrm{g}-\mathrm{Fe} \mathrm{m}^{-2} \mathrm{~d}^{-1}$ (overall mean of 3,456 $\pm 3,270 \mu \mathrm{g}-\mathrm{Fe} \mathrm{m}{ }^{-2} \mathrm{~d}^{-1}, \mathrm{n}=66$ ). This represents an areally averaged dissolved-Fe load to the lake water column of $691 \pm 654 \mathrm{~kg} \mathrm{~d}^{-1}$, assuming a lake area of 200 $\mathrm{km}^{2}$. These values are consistent with those reported previously for three sites in the northern region of the lake over a 4-year study $\left(3,881 \pm 3,640 \mu \mathrm{g}-\mathrm{Fe} \mathrm{m}^{-2} \mathrm{~d}^{-1}, \mathrm{n}=19\right.$; Kuwabara and others, 2012a). By comparison, estimates of dissolved-Fe loads from the inlet tributaries, sampled in the spring and early summer of 2013 and 2014 (table 4), were $169 \pm 108 \mathrm{~kg} \mathrm{~d}^{-1}(\mathrm{n}=7)$. Despite the fact that the riverine source of dissolved Fe was lower than the internal benthic source, unlike SRP and ammonia fluxes, the lower riverine fluxes were at least in the same order of magnitude as the benthic fluxes. Results therefore suggest that riverine dissolved-Fe sources should be carefully integrated when modeling Fe transport to and through the lake. As mentioned in the "Introduction" section, Upper Klamath Lake is hypereutrophic. The maximum iron-flux estimate for oligotrophic Coeur d'Alene Lake, Idaho (down gradient of the U.S. Environmental Protection Agency [EPA] Bunker Hill Superfund Site), was 1,100 $\mu \mathrm{g}-\mathrm{Fe} \mathrm{m}^{-2} \mathrm{~d}^{-1}$ (Kuwabara and others, 2000), as determined by core incubations that include the effects of bioturbation and bioirrigation.

As with iron fluxes, dissolved-Mn flux estimates were consistently positive and varied from 22.62 to $5,454 \mu \mathrm{g}-\mathrm{Mn} \mathrm{m}^{-2} \mathrm{~d}^{-1}$ (overall mean of $1,050 \pm 902 \mu \mathrm{g}-\mathrm{Mn} \mathrm{m}^{-2} \mathrm{~d}^{-1}, \mathrm{n}=66$; table 6). These results are consistent with previous Mn-flux estimates for a study of the northern region of Upper Klamath Lake and adjacent wetlands $\left(1,100 \pm 1,600 \mu \mathrm{g}-\mathrm{Mn} \mathrm{m}^{-2} \mathrm{~d}^{-1}, \mathrm{n}=47\right.$; Kuwabara and others, $2012 \mathrm{~b})$ and similar to those reported for Coeur d'Alene Lake, Idaho $\left(1,900 \pm 590 \mathrm{mg}-\mathrm{Mn} \mathrm{m}^{-2} \mathrm{~d}^{-1}\right.$, $\mathrm{n}=12$ ), an oligotrophic lake with surficial sediment deposits of iron and manganese oxyhydroxides (Kuwabara and others, 2000; Kuwabara and others, 2003). The diffusive dissolved-Mn flux observed in this study generates an areally averaged benthic flux of $210 \pm 180 \mathrm{~kg} \mathrm{~d}^{-1}$ that exceeds by more than an order of magnitude the riverine Mn loads presented herein $\left(8 \pm 5 \mathrm{~kg} \mathrm{~d}^{-1}, \mathrm{n}=7\right.$; table 4$)$.

Arsenic (As), primarily as As(V) arsenate in oxic waters, is structurally similar to the essential nutrient phosphate and hence interferes with adenosine triphosphate (ATP) production. The disruption of this basic biochemical mechanism may be linked to a number of toxicological responses like neurotoxicity, cancer, and liver diseases (Debarshi and others, 2013). With associated concerns for human and aquatic-system health, the State of Oregon has recently lowered water-quality standards for arsenic down to $2.1 \mu \mathrm{g} \mathrm{L}{ }^{-1}$ (Atkins, 2016). Unlike dissolved $\mathrm{Fe}$ and $\mathrm{Mn}$, benthic flux of dissolved As was not consistently positive, varied from -117 to $253 \mu \mathrm{g}$-As m ${ }^{-2} \mathrm{~d}^{-1}$ (overall mean of $18 \pm 60 \mu \mathrm{g}$-As $\mathrm{m}^{-2} \mathrm{~d}^{-1}, \mathrm{n}=66$; table 6), and was an order of magnitude lower in absolute value than Fe or Mn benthic flux. These results represent, to our knowledge, the first publication of benthic-flux measurements for dissolved As in any part of the UKL watershed, and so they are not directly comparable to previously published results from the lake. However, using peeper deployments, Martin and Pedersen (2002) 
reported much higher and consistently positive benthic flux for dissolved $(0.45-\mu \mathrm{m}$ filtered) arsenic that varied from 4,904 to $10,411 \mu \mathrm{g}$-As $\mathrm{m}^{-2} \mathrm{~d}^{-1}$ in mining-impacted Balmer Lake, Ontario, Canada. The diffusive dissolved-As flux observed in this study generates an areally averaged benthic flux of $4 \pm 12$ $\mathrm{kg} \mathrm{d}^{-1}$ that is of similar magnitude to the estimated maximum spring As loads from the lake's inlet tributaries presented herein $\left(3 \pm 4 \mathrm{~kg} \mathrm{~d}^{-1}, \mathrm{n}=7\right.$; table 4$)$. In their study of the Link River, immediately downgradient of Upper Klamath Lake, Sullivan and Rounds (2016) determined instantaneous loads of dissolved $\left(0.45-\mu \mathrm{m}\right.$ filtered) arsenic of $15.4 \pm 5.2 \mathrm{~kg} \mathrm{~d}^{-1}\left(\mathrm{n}=9\right.$; a range from 8.7 to $\left.21.7 \mathrm{~kg} \mathrm{~d}^{-1}\right)$. That As load was primarily in the dissolved phase $(92.6 \pm 9.0$ percent; $n=9)$. In comparison to SRP and ammonia, benthic sources (and sometimes sinks) for dissolved As appear to play a lesser role in overall arsenic transport.

Very little is known about vanadium (V) distribution and transport in Upper Klamath Lake, and it has heretofore garnered minimal interest. The magnitude of dissolved-V benthic flux was clearly lower than the magnitude of dissolved Fe or Mn (table 6). However, a brief discussion of V fluxes is provided because they are similar in magnitude to dissolved As and two orders of magnitude greater than dissolved cobalt, nickel, copper, zinc, cadmium, and lead. Vanadium distributions in rivers and estuaries have been studied because of vanadium's association with certain uranium deposits, enrichment in bituminous materials, and redox geochemistry (Shiller and Boyle, 1987). The linkage between $\mathrm{P}$ and $\mathrm{V}$ owing to competitive scavenging when hydrothermal precipitates form (Feely and others, 1998) may also be pertinent to subsequent $\mathrm{P}$ and $\mathrm{V}$ remobilization from similar precipitates in the Klamath River Basin (Morford and Emerson, 1999). As one might expect of an adsorbing anion, vanadium flux was predominantly negative, varying between -179 and $3 \mu \mathrm{g}-\mathrm{V} \mathrm{m}^{-2} \mathrm{~d}^{-1}$ (overall mean of $-53 \pm 35 \mu \mathrm{g}-\mathrm{V} \mathrm{m}^{-2} \mathrm{~d}^{-1}, \mathrm{n}=66$; table 6). Dissolved-V benthic flux observed in this study generates an areally averaged benthic flux of $-11 \pm 7 \mathrm{~kg} \mathrm{~d}^{-1}$. In contrast, Harita and others (2005) modeled a positive $\mathrm{V}$ benthic flux from Lake Biwa, Japan, of $7 \pm 3 \mu \mathrm{g}-\mathrm{V} \mathrm{m}^{-2} \mathrm{~d}^{-1}$, based on seasonal changes in $\mathrm{pH}$ and water-column $\mathrm{V}$. Consistent with Harita's modeling efforts, there was a positive correlation between $\mathrm{pH}$ and dissolved water-column $\mathrm{V}$ in this study $(\mathrm{r}=0.43, \mathrm{p}<0.01, \mathrm{n}=72)$. However, a negative rather than positive correlation between $2013 \mathrm{~V}$ benthic fluxes and $\mathrm{pH}(\mathrm{r}=-0.34, \mathrm{p}<0.01, \mathrm{n}=62)$ is in contrast to the Lake Biwa work and suggests site-specific differences in $\mathrm{V}$ and adsorbent speciation.

In comparison to iron and manganese fluxes, benthic fluxes for dissolved cobalt, nickel, copper, zinc, cadmium, and lead were at least three orders of magnitude lower than either dissolved iron or manganese fluxes (table 6). This observation is consistent with previously reported results from Upper Klamath Lake (Kuwabara and others, 2012a). Some of these dissolved trace metals (for example, copper and zinc) may generate reduced rates of primary production when they exist in the free-ion form. Although a decline in primary production may help mitigate eutrophic and suboxic conditions, the mean flux of both copper and zinc is negative and hence is not expected to exacerbate any toxic effects on primary production (Kuwabara and Leland, 1986; Stauber and Florence, 1987). In addition, both copper and zinc would thermodynamically favor chelation with dissolved humic substances, represented herein as DOC (Donat and others, 1994), over the free-ion form.

\section{Dissolved (0.2- $\mu \mathrm{m}$ Filtered) Trace Elements in the Water Column in 2013}

Volcanic pumice, a dominant component of UKL inorganic sediment, generates consistently low particulate trace-metal concentrations relative to other lacustrine environments (Martin and Rice, 1981). Although information about dissolved, and hence more biologically available, trace metals in Upper Klamath Lake is sparse (Kuwabara and others, 2007; Kuwabara and others, 2009), existing data generally reflect a trace-metal-depleted environment in the dissolved phase. Data described in this section represent dissolved trace-element concentrations from surface-grab samples collected 
approximately $0.5 \mathrm{~m}$ below the surface using a clean technique ("Methods" section; table 7). As previously reported for Upper Klamath Lake, many of those dissolved metals (for example, cadmium, cobalt, lead, nickel, and zinc) were present at dissolved concentrations below or near detection limits (Kuwabara and others, 2009; Kuwabara, 2012a). The discussion below focuses on water-column traceelement data for dissolved iron (Fe), manganese (Mn), and arsenic (As). These trace elements are of particular interest because they are potentially limiting micronutrients or toxicants, and their concentrations are elevated relative to the other dissolved trace elements.

Concentrations of dissolved $\mathrm{Fe}$, an essential micronutrient for primary production, varied between 4.51 and $29.29 \mu \mathrm{g}-\mathrm{Fe} \mathrm{L}^{-1}$ (overall mean of $9.10 \pm 5.17 \mu \mathrm{g}-\mathrm{Fe} \mathrm{L}^{-1}, \mathrm{n}=75$; table 7 ). That is, dissolved-Fe depletion in the lake water column was not observed at any site, as one would expect if Fe served consistently as a limiting nutrient (Kuwabara and others, 2009). Furthermore, there was no difference in dissolved-Fe concentrations between sampling dates as the intial AFA bloom developed.

Concentrations of dissolved $\mathrm{Mn}$, an essential micronutrient for primary production, in the 2013 spatial study exhibited a range from 0.13 to $7.27 \mu \mathrm{g}-\mathrm{Mn} \mathrm{L}^{-1}$ (overall mean of $0.79 \pm 0.94 \mu \mathrm{g}-\mathrm{Mn} \mathrm{L}^{-1}$, $\mathrm{n}=75$; table 7). During the first sampling, on May 23, 2013, as the AFA bloom began, dissolved Mn varied between 0.86 and $7.27 \mu \mathrm{g}-\mathrm{Mn} \mathrm{L}^{-1}$ (mean of $1.05 \pm 2.72 \mu \mathrm{g}-\mathrm{Mn} \mathrm{L}^{-1}, \mathrm{n}=24$ ). By comparison, dissolved $\mathrm{Mn}$ in the lake water column on June 13, 2013, as the bloom progressed, varied between 0.13 and $0.74 \mu \mathrm{g}-\mathrm{Mn} \mathrm{L}^{-1}$ (sampling-date mean of $0.42 \pm 0.10 \mu \mathrm{g}-\mathrm{Mn} \mathrm{L}^{-1}, \mathrm{n}=24$ ). As the initial AFA peak was approached on July 3, 2013, dissolved Mn rebounded to higher values relative to June 13 (range from 0.28 to $1.66 \mu \mathrm{g}-\mathrm{Mn} \mathrm{L}^{-1}$, sampling-date mean of $0.86 \pm 0.28 \mu \mathrm{g}-\mathrm{Mn} \mathrm{L}^{-1}, \mathrm{n}=24$ ). Despite the observed temporal trend with the development of the initial AFA bloom in 2013, all samples had detectable dissolved $\mathrm{Mn}$; that is, $\mathrm{Mn}$ depletion in the water column was not evident.

Dissolved As varied between 3.62 and $12.58 \mu \mathrm{g}$-As L ${ }^{-1}$ (overall mean of $7.34 \pm 1.94 \mu \mathrm{g}-\mathrm{As} \mathrm{L}{ }^{-1}$, $\mathrm{n}=76$; table 7). As the initial AFA bloom developed, dissolved-As concentrations increased (5.74 \pm 2.31 $\mu \mathrm{g}$-As L ${ }^{-1}, \mathrm{n}=24$, on May 23, 2013; $7.24 \pm 0.68 \mu \mathrm{g}$-As L ${ }^{-1}, \mathrm{n}=24$, on June 13, 2013, and $9.51 \pm 1.94 \mu \mathrm{g}$ $\mathrm{As} \mathrm{L}^{-1}, \mathrm{n}=24$, on July 3, 2013). This temporal behavior will be discussed in greater detail in the 2014 water-column trace-element section below.

Aside from $\mathrm{Fe}, \mathrm{Mn}$, and $\mathrm{As}$, dissolved-copper $(\mathrm{Cu})$ concentrations in the water column were also consistently above detection limits $\left(>0.01 \mu \mathrm{g}-\mathrm{Cu} \mathrm{L}^{-1}\right)$, with a range from 0.02 to $1.22 \mu \mathrm{g}-\mathrm{Cu} \mathrm{L}{ }^{-1}$ (overall mean of $0.24 \pm 0.21 \mu \mathrm{g}-\mathrm{Cu} \mathrm{L}^{-1}, \mathrm{n}=75$; table 7). Dissolved-vanadium (V) concentrations were even higher, with a range from 7.55 to $13.60 \mu \mathrm{g}-\mathrm{V} \mathrm{L}^{-1}$ (overall mean of $9.86 \pm 1.34 \mu \mathrm{g}-\mathrm{V} \mathrm{L}^{-1}, \mathrm{n}=75$; table 7). Although not a primary focus of this study, summary statistics are presented for dissolved $\mathrm{Cu}$ and $\mathrm{V}$ because of their magnitude relative to the remaining five trace elements and their consistent detectability. Although both have biogeochemical significance $(\mathrm{Cu}$ as a micronutrient and potential toxicant, and $\mathrm{V}$, as vanadate, as a competitive adsorbate with orthophosphate), the environmental significance of these solutes within UKL has yet to be demonstrated. The variability in dissolved traceelement concentrations observed in our 2013 spatial study may reflect processes (for example, air temperatures, wind directions, and current patterns) that operate over multiple time scales, some much shorter than the frequency of profiler deployments in 2013. Therefore, a greater temporal resolution of this variability was a primary objective the UKL studies in 2014.

\section{Benthic Chlorophyll in 2013}

As pelagic phytoplankton grow, senesce, and settle to the lakebed, benthic-chlorophyll measurements can help track that deposited carbon load. Based on the elevated algal biomass generated in the water column of hypereutrophic aquatic systems like Upper Klamath Lake, one might expect changes in benthic chlorophyll as blooms wax and wane. In 2013, benthic chlorophyll varied between 
0.5 and 52.8 micrograms per square centimeter $\left(\mu \mathrm{g} \mathrm{cm}^{-2}\right.$ ) (overall mean of $5.44 \pm 8.36 \mu \mathrm{g} \mathrm{cm}^{-2}, \mathrm{n}=46$; table 8). The ratio of benthic chlorophyll to the sum of benthic chlorophyll plus pheophytin increased between the May $(0.26 \pm 0.12, \mathrm{n}=21)$ and June $(0.37 \pm 0.17, \mathrm{n}=21)$ samplings. Corresponding mean values for benthic chlorophyll were $3.82 \mu \mathrm{g} \mathrm{cm}^{-2}$ in May and $7.89 \mu \mathrm{g} \mathrm{cm}^{-2}$ in June, and for pheophytin were $9.89 \mu \mathrm{g} \mathrm{cm}^{-2}$ in May and $8.60 \mu \mathrm{g} \mathrm{cm}^{-2}$ in June. Among habitats, the ratio of benthic chlorophyll to the sum of benthic chlorophyll plus pheophytin, during May and June samplings, was lowest at the trench sites $(0.18 \pm 0.06, \mathrm{n}=6)$ and highest at the littoral and open-lake sites $(0.41 \pm 0.15$ and $0.27 \pm$ 0.13 , respectively, $\mathrm{n}=18$ ). The narrow, deep morphology of the trench may be prone to scouring events that minimize the accumulation of benthic chlorophyll. Prior to the bloom on May 23, 2013, benthic chlorophyll at littoral sites varied between 2.6 and $9.5 \mu \mathrm{g} \mathrm{cm}^{-2}$ (habitat mean for that date was $6.7 \pm 2.7$ $\mu \mathrm{g} \mathrm{cm}^{-2}, \mathrm{n}=9$ ). At open-lake sites, benthic chlorophyll was lower, with a range from 0.5 to $3.1 \mu \mathrm{g} \mathrm{cm}^{-2}$ (habitat mean of $1.7 \pm 0.8 \mu \mathrm{g} \mathrm{cm}^{-2}, \mathrm{n}=9$ ). As the bloom progressed, planktonic carbon was transported horizontally and vertically, and habitat differences were mitigated. On June 13, 2013, only 3 weeks after the previous sampling trip, benthic chlorophyll measurements for the littoral and open-lake sites were no longer different and more variable within habitat sites than observed on May $23(9.5 \pm 6.1$ and $8.6 \pm$ $11.6 \mu \mathrm{g} \mathrm{cm}^{-2}$, respectively, $\mathrm{n}=9$ ). Such changes in benthic carbon distributions may affect the distribution of benthic invertebrates and hence solute efflux by their respective communities. Growth and subsequent settling of phytoplankton augment the benthic carbon source that supports microbial and macroinvertebrate assemblages near the sediment-water interface with feeding and foraging mechanisms, and in so doing, may seasonally enhance the benthic flux of solutes (Kuwabara and others, 1999; Boudreau and Jorgensen, 2001).

Benthic pheophytin varied between 1.9 and $29.2 \mu \mathrm{g} \mathrm{cm}^{-2}$ (overall mean of $8.81 \pm 5.43 \mu \mathrm{g} \mathrm{cm}^{-2}$, $\mathrm{n}=46$ ). In comparison to benthic-chlorophyll concentrations, pheophytin concentrations at trench sites were similar to the rest of lake $\left(5.9 \pm 2.5 \mu \mathrm{g} \mathrm{cm}^{-2}, \mathrm{n}=6\right)$. Furthermore, benthic pheophytin prior to and during the bloom were similar $\left(9.89 \pm 5.67\right.$ and $8.60 \pm 5.34 \mu \mathrm{g} \mathrm{cm}^{-2}$ on May 23 and June 13, respectively, $\mathrm{n}=21$ ).

As a coarse indicator of the reproductive status of the benthic algal community, the ratio of benthic chlorophyll to the sum of pheophytin plus benthic chlorophyll varied between 0.10 and 0.74 (overall mean of $0.34 \pm 0.29, \mathrm{n}=46$ ). Pheopigments represent degradation products of chlorophyll, so the fact that only 4 of 46 tabulated ratios are $\geq 0.5$ (table 8 ) suggests that phytoplankton cells degrade or senesce then settle to the lakebed, or that active benthic invertebrate communities consume benthic algae (or settled phytoplankton) to generate feces rich in pheopigments (Thompson and others, 1981; Light and John, 1998; U.S. Environmental Protection Agency, 2000).

\section{Benthic Invertebrate Assemblages in 2013}

Average invertebrate density over the study period in 2013 was $12,610 \pm 7,505$ individuals (inds) $\mathrm{m}^{-2}(\mathrm{n}=63)$ (table 9). Each of the 63 samples represented the mean of 3 Ekman grabs. Oligochaeta, Chironomidae, and Hirudinea represented 57, 25, and 15 percent, respectively, of all organisms identified. Average taxon richness (number of unique taxa identified) per sample was $16.1 \pm$ $3.7(\mathrm{n}=63)$ and ranged from 8.7 to 26.0 . Total taxon richness (total number of unique taxa identified) was 74; 24 were oligochaetes, 14 were chironomids, and 10 were hirudineans.

Average invertebrate densities during each of the three collecting dates were very similar. Total densities on May 23, June 13, and July 3, 2013, were 11,888 $\pm 6,858$ inds $\mathrm{m}^{-2}$ ( $\left.\mathrm{n}=21\right), 12,945 \pm 7,376$ inds $\mathrm{m}^{-2}(\mathrm{n}=21)$, and $12,998 \pm 8,506$ inds $\mathrm{m}^{-2}(\mathrm{n}=21)$, respectively. Oligochaetes decreased in composition from a high of 66 percent to 50 percent of the total density in samples over the study period. Chironomids remained approximately the same at 25 percent, and hirudineans increased from a 
low of 6 percent in May 2013 to a high of 21 percent in July 2013. These changes in composition are generally a function of the life histories of the taxa over this part of the late spring and early summer months.

\section{4-Temporal Variability (Weekly Interval) Study}

Results of the 27-week Upper Klamath Lake sampling in 2014 were summarized in three temporal periods, each period involving 9 weeks of profiler deployments, water column and benthic sampling. Based on water-chlorophyll measurements taken weekly at the profiler-deployment sites (table 11), the first period, representing pre-bloom conditions, spanned the period between April 15 through June 10, 2014. The annual cyanobacterial blooms marked the second period between June 17 and August 13, 2014. Post-bloom conditions were represented by a third period, between August 20 and October 16, 2014. Tables presenting results from the 2014 sampling effort (tables 10-15) have shaded blocks of rows to distinguish the bloom period from the unshaded pre-bloom and post-bloom sampling periods.

\section{Ancillary Parameters in 2014}

As in 2013, vertical water-column profiles of ancillary parameters (depth, temperature, specific conductivity, $\mathrm{pH}$, and dissolved oxygen) were collected using sonde deployments. The sampling proximity around open-lake site ON01, the area of focus for 2014 temporal study, was $<3 \mathrm{~m}$ in depth. In comparison with 2013 sonde data (tables 2 and 10), specific conductivity values in 2014 varied over an even narrower range (112 to $142 \mu \mathrm{S} \mathrm{cm}^{-1}$ ). Similar to 2013 results, lowest values for specific conductivity $\left(115 \pm 3 \mu \mathrm{S} \mathrm{cm}^{-1}, \mathrm{n}=18\right)$ were observed during the pre-bloom period between April 16 through June 11, 2014, as snow melt diluted lake waters. By comparison, as the cyanobacterial blooms progressed (between June 18 through August 13, 2014), the mean specific conductivity was $121 \pm 6 \mu \mathrm{S}$ $\mathrm{cm}^{-1}$ ( $\left.\mathrm{n}=18\right)$. In July 2013, much higher specific conductivity was observed $\left(210 \pm 76 \mu \mathrm{S} \mathrm{cm}^{-1}, \mathrm{n}=40\right)$ relative to 2014, an indication of interannual variability of water quality flowing into the lake or evaporation rates. Following the bloom period (between August 20 and October 16, 2014), mean specific conductivity increased $\left(129 \pm 4 \mu \mathrm{S} \mathrm{cm}^{-1}, \mathrm{n}=18\right)$ as temperature and evaporation increased relative to pre-bloom conditions. Consistent with 2013 results, water-column temperatures were lowest during pre-bloom period $\left(14.7 \pm 2.8^{\circ} \mathrm{C}\right)$ and expectedly peaked during the cyanobacterial blooms $(21.4$ $\pm 2.3{ }^{\circ} \mathrm{C}$, table 10$)$. Water temperature then declined during the post-bloom period $\left(16.1 \pm 3.0^{\circ} \mathrm{C}\right)$.

As observed in 2013, dissolved oxygen (DO) consistently decreased with depth (table 10). During the pre-bloom period, the decrease with depth in percent DO saturation was $21 \pm 26.5$ percent (range from 1.1 to 79.7 percent decreased DO saturation with depth, $n=9$ ). During the cyanobacterial blooms between June 18 and August 13, 2014, the decrease in percent DO saturation with depth was $36.0 \pm 22.9$ percent (range from 9.1 to 72.4 percent, $n=6$ ). After the bloom period, that is, during the August 20 to October 16, 2014, deployments, the mean decrease in percent DO saturation with depth was $10.8 \pm 10.0$ percent (range from 0.2 to 23.9 percent, $n=9$ ), suggesting that the benthic oxygen demand, generated by settled cyanobacterial biomass, was quickly dissipated following the bloom.

Consistent with 2014 phytoplankton-bloom dynamics in the lake, mean $\mathrm{pH}$ during pre-bloom deployments $(8.0 \pm 0.5, \mathrm{n}=18)$ increased during the bloom period $(9.4 \pm 0.5, \mathrm{n}=18)$, then decreased following the bloom $(7.8 \pm 0.6, \mathrm{n}=18$; table 10). As mentioned above in the discussion of 2013 ancillary-parameter results, $\mathrm{pH}$ above the negative logarithm of the acid dissociation constant for the ammonium ion (9.3) may generate environmental concerns by imposing a variety of toxicity and nutrient-deficiency problems. However, the coincidence of both high $\mathrm{pH}$ and elevated ammonia concentrations in the UKL water column is episodic and infrequent (tables 2, 5, 10, and 13). 


\section{Benthic Flux of Macronutrients in 2014}

During all three sampling periods, SRP benthic flux was consistently positive (table 12). SRP flux during the pre-bloom period varied between 1.55 and $4.26 \mathrm{mg}_{-} \mathrm{P} \mathrm{m}^{-2} \mathrm{~d}^{-1}\left(2.89 \pm 0.96 \mathrm{mg}-\mathrm{P} \mathrm{m}^{-2} \mathrm{~d}^{-1}\right.$, $\mathrm{n}=9$ ). This represents an areally averaged SRP (as P) load to the lake water column of $578 \pm 192 \mathrm{~kg} \mathrm{~d}^{-1}$, assuming a lake area of $200 \mathrm{~km}^{2}$. By comparison, the mean SRP load from the inlet tributaries, sampled in the spring and early summer of 2013 and 2014 (table 4), was $133 \pm 15 \mathrm{~kg} \mathrm{~d}^{-1}(\mathrm{n}=7)$. As the summer cyanobacterial blooms (AFA then additional species like Microcystis aeruginosa) progressed during the bloom period, SRP flux displayed greater variability relative to pre-bloom conditions, varying between 1.17 and $5.77 \mathrm{mg}-\mathrm{P} \mathrm{m} \mathrm{m}^{-2} \mathrm{~d}^{-1}\left(2.80 \pm 1.71 \mathrm{mg}-\mathrm{P} \mathrm{m}^{-2} \mathrm{~d}^{-1}, \mathrm{n}=9\right)$. Following the blooms, SRP fluxes decreased to as low as $0.60 \mathrm{mg}-\mathrm{P} \mathrm{m}^{-2} \mathrm{~d}^{-1}$, then rebounded in the final 3 weeks of sampling to $1.74 \mathrm{mg}-\mathrm{P}$ $\mathrm{m}^{-2} \mathrm{~d}^{-1}$ toward pre-bloom conditions (mean of $1.41 \pm 0.69 \mathrm{mg}-\mathrm{P} \mathrm{m}^{-2} \mathrm{~d}^{-1}, \mathrm{n}=9$; lowest of the three periods). Over the 27-week sampling period, the mean SRP flux was $2.37 \pm 1.35 \mathrm{mg}^{-\mathrm{P} \mathrm{m}}{ }^{-2} \mathrm{~d}^{-1}(\mathrm{n}=27)$, representing an areally averaged SRP load to the lake water column of $474 \pm 270 \mathrm{~kg} \mathrm{~d}^{-1}$, again higher than the spring estimates for SRP tributary loads. Note that tributary solute loads decrease during the summer as discharge decreases (for example, to zero in the Williamson River wetland headwaters; table 4).

As observed in 2013 and previous studies (Kuwabara and others, 2012a), benthic flux of ammonia was consistently positive over the 27-week sampling period in 2014 (table 12). During the

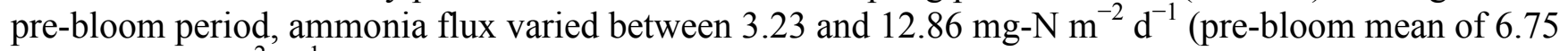

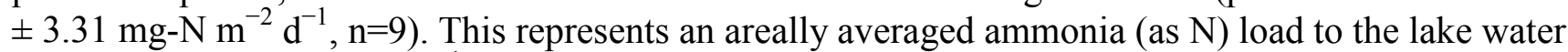
column of 1,350 $\pm 662 \mathrm{~kg} \mathrm{~d}^{-1}$. By comparison, the mean ammonia load from the inlet tributaries, sampled in the spring and early summer of 2013 and 2014 (table 4), was an order of magnitude lower $\left(82 \pm 112 \mathrm{~kg} \mathrm{~d}^{-1}, \mathrm{n}=7\right)$. During the bloom period, when a succession of cyanobacteria appeared, ammonia flux (like SRP) became more temporally variable than pre-bloom conditions, varying between 3.95 and $20.62 \mathrm{mg}^{-\mathrm{N} \mathrm{m}^{-2}} \mathrm{~d}^{-1}\left(11.11 \pm 5.18 \mathrm{mg}-\mathrm{N} \mathrm{m}^{-2} \mathrm{~d}^{-1}, \mathrm{n}=9\right)$. Following the blooms, ammonia flux decreased to as low as $1.74 \mathrm{mg}-\mathrm{N} \mathrm{m}^{-2} \mathrm{~d}^{-1}$, then rebounded (as observed with SRP flux) in the final 3 weeks of sampling to $6.48 \mathrm{mg}-\mathrm{N} \mathrm{m}^{-2} \mathrm{~d}^{-1}$, approaching the pre-bloom mean flux provided above (post-

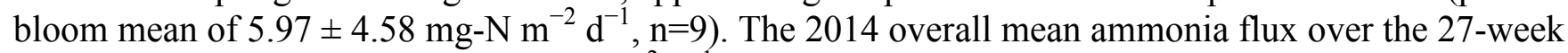

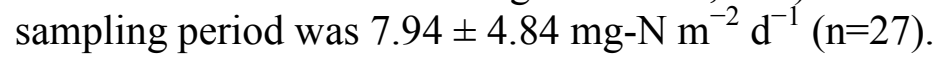

Consistent with 2013 results, and in contrast to SRP and ammonia fluxes, no positive nitrate fluxes were observed in 2014, varying between -3.50 and $0.00 \mathrm{mg}-\mathrm{N} \mathrm{m}^{-2} \mathrm{~d}^{-1}$, with an overall mean of $-0.68 \pm 1.11 \mathrm{mg}-\mathrm{N} \mathrm{m}^{-2} \mathrm{~d}^{-1}(\mathrm{n}=27$, table 12$)$. This represents an areally averaged nitrate (as $\left.\mathrm{N}\right)$ load to the lake of between -700 to $0 \mathrm{~kg} \mathrm{~d}^{-1}$ (that is, a net nitrate sink to the lakebed). During the pre-bloom period, nitrate flux varied between -2.16 and $0.00 \mathrm{mg}-\mathrm{N} \mathrm{m}^{-2} \mathrm{~d}^{-1}\left(-0.41 \pm 0.73 \mathrm{mg}-\mathrm{N} \mathrm{m}^{-2} \mathrm{~d}^{-1}, \mathrm{n}=9\right)$. Note that a 0.00 calculated flux indicates nondetectable flux because all profiler samples across the sediment-water interface were below detection limits (for nitrate, $<0.01 \mathrm{mg}-\mathrm{N} \mathrm{L}^{-1}$ ). During the cyanobacterial bloom period that followed, nitrate flux became less variable $\left(-0.32 \pm 0.48 \mathrm{mg}^{-\mathrm{N} \mathrm{m}} \mathrm{m}^{-2}\right.$ $\mathrm{d}^{-1}, \mathrm{n}=9$ ), again in contrast to SRP and ammonia fluxes. As a further contrast with SRP and ammonia fluxes, the post-bloom period provided the most negative and most variable nitrate fluxes, varying between -3.50 and $0.00 \mathrm{mg}-\mathrm{N} \mathrm{m}^{-2} \mathrm{~d}^{-1}$ (post-bloom mean of $-1.29 \pm 1.61 \mathrm{mg}-\mathrm{N} \mathrm{m}^{-2} \mathrm{~d}^{-1}, \mathrm{n}=9$ ).

As observed in 2013 and previous studies, benthic fluxes for dissolved silica were consistently positive, that is, a benthic silica source to the lake water column, as observed for SRP and ammonia. During the pre-bloom period, silica flux varied between 10.58 and $72.37 \mathrm{mg}-\mathrm{SiO}_{2} \mathrm{~m}^{-2} \mathrm{~d}^{-1}(41.68 \pm$ $22.41 \mathrm{mg}-\mathrm{SiO}_{2} \mathrm{~m}^{-2} \mathrm{~d}^{-1}, \mathrm{n}=9$; table 12). This benthic flux represents an areally averaged dissolved silica (as $\mathrm{SiO}_{2}$ ) load to the lake water column of $8,340 \pm 4,480 \mathrm{~kg} \mathrm{~d}^{-1}$. By comparison, the mean silica load from the inlet tributaries, sampled in the spring and early summer of 2013 and 2014 (table 4), was an 
order of magnitude higher $\left(90,600 \pm 15,700 \mathrm{~kg} \mathrm{~d}^{-1}, \mathrm{n}=6\right)$. That is, the benthic silica source is less dominant over the riverine source, relative to SRP and ammonia. During the cyanobacterial bloom period, dissolved-silica flux varied between 27.16 and $106.52 \mathrm{mg}-\mathrm{SiO}_{2} \mathrm{~m}^{-2} \mathrm{~d}^{-1}\left(53.37 \pm 26.02 \mathrm{mg}-\mathrm{SiO}_{2}\right.$ $\mathrm{m}^{-2} \mathrm{~d}^{-1}, \mathrm{n}=9$ ). Following the blooms, silica flux decreased to as low as $6.38 \mathrm{mg}-\mathrm{SiO}_{2} \mathrm{~m}^{-2} \mathrm{~d}^{-1}$, but as observed for SRP and ammonia fluxes, silica flux rebounded in the final weeks of sampling to 18.11 $\mathrm{mg}_{-} \mathrm{SiO}_{2} \mathrm{~m}^{-2} \mathrm{~d}^{-1}$, toward pre-bloom conditions (post-bloom mean of $15.48 \pm 10.49 \mathrm{mg}-\mathrm{SiO}_{2} \mathrm{~m}^{-2} \mathrm{~d}^{-1}$, $\mathrm{n}=9$ ). The 2014 overall mean silica flux was $36.85 \pm 25.64 \mathrm{mg}-\mathrm{SiO}_{2} \mathrm{~m}^{-2} \mathrm{~d}^{-1}$ (range from 6.38 to 106.52 $\mathrm{mg}-\mathrm{SiO}_{2} \mathrm{~m}^{-2} \mathrm{~d}^{-1}, \mathrm{n}=27$ ), representing an areally averaged silica load to the lake water column of 7,370 $\pm 5,130 \mathrm{~kg} \mathrm{~d}^{-1}$, much lower than the spring estimates for silica tributary loads $\left(90,600 \pm 15,700 \mathrm{~kg} \mathrm{~d}^{-1}\right.$, $\mathrm{n}=7)$.

As observed in 2013, and similar to nitrate flux, benthic flux of dissolved organic carbon (DOC) was often negative (removed from the water column to the lakebed), particularly during the cyanobacterial bloom period (table 12). During the pre-bloom period, DOC flux varied between -3.63 and $0.78 \mathrm{mg}_{-} \mathrm{C} \mathrm{m}^{-2} \mathrm{~d}^{-1}\left(-0.64 \pm 1.41 \mathrm{mg}-\mathrm{C} \mathrm{m}^{-2} \mathrm{~d}^{-1}, \mathrm{n}=9\right)$. In the bloom period that followed, DOC flux became more negative and variable $\left(-8.57 \pm 3.46 \mathrm{mg}_{-} \mathrm{C} \mathrm{m}^{-2} \mathrm{~d}^{-1}, \mathrm{n}=9\right)$. As a mirror image of the 2014 SRP and ammonia flux time series, the DOC flux peaked after the bloom on September 17, 2014 (11.53 mg-C m ${ }^{-2} \mathrm{~d}^{-1}$ with a post-bloom mean of $\left.-0.22 \pm 5.46 \mathrm{mg}-\mathrm{C} \mathrm{m}^{-2} \mathrm{~d}^{-1}, \mathrm{n}=9\right)$, then reverted back to negative values during the final sampling weeks. Over the 27-week sampling period, DOC flux varied between -14.37 and $11.53 \mathrm{mg}_{-} \mathrm{C} \mathrm{m}^{-2} \mathrm{~d}^{-1}$, with a mean of $-3.15 \pm 5.36 \mathrm{mg}_{-} \mathrm{C} \mathrm{m}^{-2} \mathrm{~d}^{-1}(\mathrm{n}=27)$. This represents an areally average DOC (as C) load to the lake of between $-2,870$ and $2,310 \mathrm{~kg} \mathrm{~d}^{-1}$. In contrast to the greater magnitudes of SRP and ammonia benthic fluxes over riverine loads, DOC loads, measured in the spring and early summer of 2013 and 2014, were between 1,874 and 8,922 $\mathrm{kg} \mathrm{d}^{-1}$ $\left(4,322 \pm 2,525 \mathrm{~kg} \mathrm{~d}^{-1}, \mathrm{n}=7\right)$. As observed for dissolved silica, benthic DOC sources were not dominant over riverine sources to the lake.

\section{Dissolved (0.2- $\mu \mathrm{m}$ Filtered) Nutrients in the Water Column in 2014}

During the 2014 temporal study, SRP varied between 0.02 and $0.25 \mathrm{mg}-\mathrm{P} \mathrm{L}^{-1}$ (overall mean of $0.08 \pm 0.07 \mathrm{mg}-\mathrm{P} \mathrm{L}^{-1}, \mathrm{n}=27$; table 13 ). These results are consistent with previous monitoring studies of the Upper Klamath Lake and adjacent Agency Lake to the north (Wong and others, 2011). During the pre-bloom period, SRP varied between 0.02 and 0.09 mg-P L ${ }^{-1}$ (mean of $0.05 \pm 0.02 \mathrm{mg}-\mathrm{P} \mathrm{L}^{-1}, \mathrm{n}=9$ ). SRP increased in the lake water column during the subsequent bloom period, with a range from 0.04 to $0.25 \mathrm{mg}-\mathrm{P} \mathrm{L}^{-1}$ (mean of $0.15 \pm 0.07 \mathrm{mg}-\mathrm{P} \mathrm{L}^{-1}, \mathrm{n}=9$ ), a somewhat counterintuitive behavior if SRP served consistently as the limiting nutrient. Finally, during the post-bloom period, SRP decreased to pre-

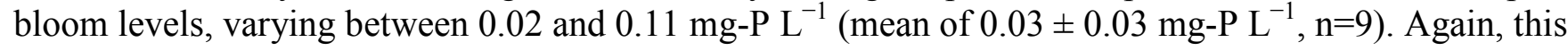
temporal trend over the three bloom-related periods, over 27 consecutive weeks, is not what would be expected if phosphorus served consistently as the limiting nutrient for primary production. Furthermore, as observed in 2013, all samples had detectable SRP (SRP depletion did not occur in the lake water column).

Dissolved-ammonia concentrations varied from $<0.007$ to $0.600 \mathrm{mg}-\mathrm{N} \mathrm{L}^{-1}$ (overall mean of 0.11 $\pm 0.16 \mathrm{mg}_{-\mathrm{N} \mathrm{L}}^{-1}, \mathrm{n}=27$; table 13). Consistent with 2013 results, there were 7 of 27 weeks where undetectable dissolved ammonia concentrations were observed (that is, $<0.007 \mathrm{mg}-\mathrm{N} \mathrm{L}^{-1}$ ), all prior to the highest observed chlorophyll concentrations on July 2 and July 8, 2014 (that is, 257 and $250 \mu \mathrm{g} \mathrm{L}^{-1}$, respectively). The pre-bloom period displayed the lowest dissolved ammonia, between $<0.007$ to 0.070 $\mathrm{mg}^{-\mathrm{N} \mathrm{L}^{-1}}$ (mean of $0.02 \pm 0.02 \mathrm{mg}-\mathrm{N} \mathrm{L}^{-1}, \mathrm{n}=9$ ). Coupled with elevating temperatures during the prebloom period (table 10), as well as low water-column nitrate and nitrite, these low dissolved inorganic nitrogen (DIN) concentrations (ammonia plus undetectable nitrate and nitrite) would favor nitrogen- 
fixing species like AFA (Beversdorf and others, 2013). Unlike 2013 results, un-ionized water-column ammonia concentrations in 2014 (table 10) were never observed above the LC50 threshold for Lost River suckers (0.45 mg-N L ${ }^{-1}$; Meyer and Hansen, 2002), which is likely indicative of interannual variability in geochemical and biological parameters. In addition, within-lake spatial variability may have contributed to the absence of observed LC50 exceedances in 2014. Ammonia concentrations at ON01 in $2013\left(0.02 \pm 0.03 \mathrm{mg}-\mathrm{N} \mathrm{L}^{-1}\right.$, range from 0.00 to $\left.0.05 \mathrm{mg}^{-\mathrm{N} \mathrm{L}}{ }^{-1}, \mathrm{n}=3\right)$ were found to be on the lower end of the distribution among all sites $\left(0.13 \pm 0.22 \mathrm{mg}-\mathrm{N} \mathrm{L}^{-1}\right.$, range from 0.00 and $1.03 \mathrm{mg}-\mathrm{N}$ $\left.\mathrm{L}^{-1}, \mathrm{n}=77\right)$. Consistent with 2013 results, the subsequent bloom period displayed higher and more variable ammonia concentrations with a range from $<0.007$ to $0.600 \mathrm{mg}^{-\mathrm{N} \mathrm{L}^{-1}}$ (mean of $0.19 \pm 0.24$ $\mathrm{mg}-\mathrm{N} \mathrm{L}^{-1}, \mathrm{n}=9$ ). Although less variable than the bloom period, the post-bloom period did not generate the highest dissolved-ammonia concentrations in 2014 , with a range from 0.025 to $0.243 \mathrm{mg}-\mathrm{N} \mathrm{L}^{-1}$

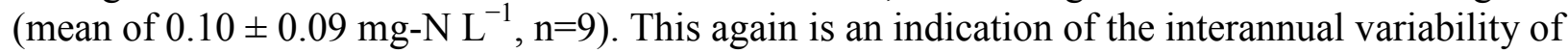
interdependent geochemical and biological parameters, as phytoplankton succession involving both nitrogen-fixing (for example, AFA) and non-nitrogen-fixing cyanobacterium (for example, $M$. aeruginosa) occur over multiple time scales (Kann, 2006; Kann, 2010). It will be useful to compare water-column trends with the timing of phytoplankton taxonomic succession in Upper Klamath Lake when taxonomic data become available.

As observed in 2013 and previously reported studies within Upper Klamath Lake (Kuwabara and others, 2009; Kuwabara and others, 2012a; Wood and others, 2006; Hoilman and others, 2008; Lindenberg and others, 2009, dissolved-nitrate concentrations were consistently low, with 5 of 27 watercolumn samples having undetectable concentrations $\left(<0.01 \mathrm{mg}-\mathrm{N} \mathrm{L}^{-1}\right)$. Concentrations varied between

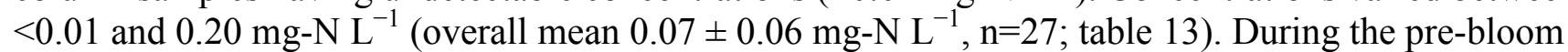

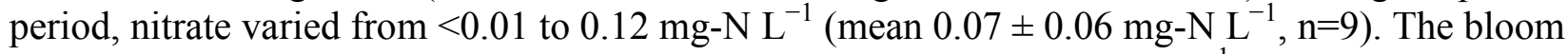
period that followed had the same nitrate range from $<0.01$ to $0.12 \mathrm{mg}-\mathrm{N} \mathrm{L}^{-1}$ (mean $0.05 \pm 0.04 \mathrm{mg}-\mathrm{N}$ $\mathrm{L}^{-1}, \mathrm{n}=9$ ). The subsequent post-bloom period displayed similar water-column nitrate concentrations, varying between $<0.01$ and $0.20{\mathrm{mg}-\mathrm{N} \mathrm{L}^{-1} \text { (mean } 0.11 \pm 0.07 \mathrm{mg}-\mathrm{N} \mathrm{L}}^{-1}, \mathrm{n}=9$ ). Neither the water column nor diffusive solute flux provided adequate nitrate in support of non-nitrogen-fixing primary producers (table 13); hence, the primary DIN source would be dissolved ammonia, when available.

Over the entire 2014 sampling period, dissolved silica varied between 36.03 and $64.03 \mathrm{mg}-\mathrm{SiO}_{2}$ $\mathrm{L}^{-1}$ (overall mean of $49.92 \pm 9.70 \mathrm{mg}_{-} \mathrm{SiO}_{2} \mathrm{~L}^{-1}, \mathrm{n}=27$; table 13). As observed in 2013, dissolved silica in the water column increased as the initial AFA bloom neared its peak and continued to increase as the bloom faded during the final post-bloom period of the study period. During the pre-bloom period, dissolved-silica concentrations were lowest, varying from 36.03 to $48.37 \mathrm{mg}_{-} \mathrm{SiO}_{2} \mathrm{~L}^{-1}$ (mean of $41.70 \pm$ $4.44 \mathrm{mg}-\mathrm{SiO}_{2} \mathrm{~L}^{-1}, \mathrm{n}=9$ ). In the bloom period that followed, dissolved silica exhibited a range from 36.78 to $60.59 \mathrm{mg}-\mathrm{SiO}_{2} \mathrm{~L}^{-1}$ (mean of $48.10 \pm 9.14 \mathrm{mg}-\mathrm{SiO}_{2} \mathrm{~L}^{-1}, \mathrm{n}=9$ ). Finally, during the post-bloom period, dissolved-silica concentrations were highest and least variable, displaying a range from 55.29 to $64.03 \mathrm{mg}_{-} \mathrm{SiO}_{2} \mathrm{~L}^{-1}$ (mean of $59.95 \pm 3.17 \mathrm{mg}-\mathrm{SiO}_{2} \mathrm{~L}^{-1}, \mathrm{n}=9$ ). This seasonal accumulation of dissolved silica in the water column is to be expected as cyanobacteria (with minimal silica requirements relative to diatoms) favorably compete for required nutrients following the spring diatom dominance.

Water-column concentrations for DOC in 2014 were more variable than observed in 2013, with a range from 3.15 to $9.33 \mathrm{mg}-\mathrm{C} \mathrm{L}^{-1}$ (overall mean of $5.44 \pm 1.77 \mathrm{mg}-\mathrm{C} \mathrm{L}^{-1}, \mathrm{n}=27$; tables 3 and 13). The lowest DOC concentrations in the water column occurred in the pre-bloom period and varied between

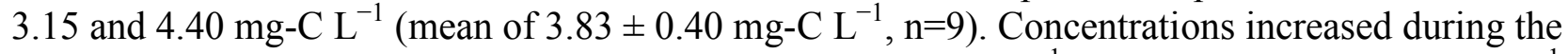
subsequent bloom period, with a range from 4.17 to $9.33 \mathrm{mg}-\mathrm{C} \mathrm{L}^{-1}$ (mean of $7.21 \pm 1.66 \mathrm{mg}^{-\mathrm{C} \mathrm{L}^{-1}}$, $\mathrm{n}=9$ ). During the post-bloom period, DOC concentrations varied between 4.45 and $6.95 \mathrm{mg}^{-\mathrm{C} \mathrm{L}^{-1}}$ (mean 
of $5.29 \pm 0.90 \mathrm{mg}-\mathrm{C} \mathrm{L}^{-1}, \mathrm{n}=9$ ). As seen with dissolved ammonia in 2014, the highest DOC concentrations occurred during the bloom period rather than the post-bloom period.

\section{Benthic Flux of Trace Metals in 2014}

Similar to the macronutrient-flux discussion above, results of the 2014 benthic flux for trace elements are summarized in the same three temporal periods based on water-column chlorophyll measurements (table 11): a pre-bloom period (April 15 through June 10, 2014), a cyanobacterial bloom period (June 17 and August 13, 2014), and a post-bloom period (August 20 and October 16, 2014). Consistent with the discussion of 2013 trace-element benthic flux, 2014 fluxes are also discussed and tabulated in units of micrograms per square meter per day $\left(\mu \mathrm{g} \mathrm{m}^{-2} \mathrm{~d}^{-1}\right)$, owing to lower solute detection limits for trace elements.

Consistent with 2013 results, benthic flux for dissolved iron (Fe) was consistently positive (that is, the lake sediments were a consistent dissolved-Fe source to the water column throughout the 2013 and 2014 sampling periods). In the pre-bloom period, dissolved-Fe benthic flux attained its highest values and varied between 1,917 and $6,058 \mu \mathrm{g}-\mathrm{Fe} \mathrm{m}^{-2} \mathrm{~d}^{-1}$ (overall mean of 3,582 $\pm 1,448 \mu \mathrm{g}-\mathrm{Fe} \mathrm{m} \mathrm{m}^{-2}$ $\mathrm{d}^{-1}, \mathrm{n}=9$; table 14). This represents an areally averaged dissolved Fe load to the lake water column (as $\mathrm{Fe}$ ) of $708 \pm 290 \mathrm{~kg} \mathrm{~d}^{-1}$. These values are consistent with those reported previously for three sites in the northern region of the lake over a 4-year study $\left(3,881 \pm 3,640 \mu \mathrm{g}-\mathrm{Fe} \mathrm{m}^{-2} \mathrm{~d}^{-1}, \mathrm{n}=19\right.$; Kuwabara and others, 2012a). By comparison, estimates of dissolved-Fe loads from the inlet tributaries, sampled in the spring and early summer of 2013 and 2014 (table 4) were $169 \pm 108 \mathrm{~kg} \mathrm{~d}^{-1}(\mathrm{n}=7)$. During the bloom period, peaks in dissolved-Fe benthic flux typically lagged water-column chlorophyll and varied between 971 and 3,731 $\mu \mathrm{g}-\mathrm{Fe} \mathrm{m}{ }^{-2} \mathrm{~d}^{-1}$ (overall mean of $1,944 \pm 1,018 \mu \mathrm{g}-\mathrm{Fe} \mathrm{m}^{-2} \mathrm{~d}^{-1}, \mathrm{n}=9$ ), converting to an areally lake-averaged dissolved-Fe load to the lake water column of $389 \pm 204 \mathrm{~kg} \mathrm{~d}^{-1}$. In the final post-bloom period, dissolved-Fe benthic flux reached its lowest values but then rebounded (similar to SRP and ammonia) during the final 3 sampling weeks and varied between 948 and 4,290 $\mu \mathrm{g}-\mathrm{Fe} \mathrm{m} \mathrm{m}^{-2}$ (overall mean of $2,151 \pm 1,171 \mu \mathrm{g}-\mathrm{Fe} \mathrm{m}^{-2} \mathrm{~d}^{-1}, \mathrm{n}=9$ ). The associated dissolved-Fe benthic load to the lake water column was $430 \pm 234 \mathrm{~kg} \mathrm{~d}^{-1}$.

Dissolved-manganese (Mn) flux estimates were consistently positive with one exception, on July 8, 2014 (that is, $-6.12 \mu \mathrm{g}-\mathrm{Mn} \mathrm{m}^{-2} \mathrm{~d}^{-1}$ ), coincident with the initial AFA peak (table 11). As with dissolved $\mathrm{Fe}$ in the pre-bloom period, dissolved-Mn benthic flux attained their highest values and varied between 331 and 1,290 $\mu \mathrm{g}-\mathrm{Mn} \mathrm{m}^{-2} \mathrm{~d}^{-1}$ (mean of $710 \pm 298 \mu \mathrm{g}-\mathrm{Mn} \mathrm{m}^{-2} \mathrm{~d}^{-1}, \mathrm{n}=9$; table 14). This represents an areally averaged dissolved-Mn load to the lake water column (as Mn) of $142 \pm 60 \mathrm{~kg} \mathrm{~d}^{-1}$. These results are similar to previous Mn-flux estimates for a study of the northern region of Upper Klamath Lake and adjacent wetlands $\left(1,100 \pm 1,600 \mu \mathrm{g}-\mathrm{Mn} \mathrm{m}^{-2} \mathrm{~d}^{-1}, \mathrm{n}=47\right.$; Kuwabara and others, $2012 b)$ but lower than those reported for Coeur d'Alene Lake, Idaho $\left(1,900 \pm 590 \mu \mathrm{g}-\mathrm{Mn} \mathrm{m}^{-2} \mathrm{~d}^{-1}\right.$, $\mathrm{n}=12$ ), where surficial Mn oxyhydroxides were visually abundant on the lakebed when Ekman grabs were collected. By comparison, estimates of dissolved-Mn loads from the inlet tributaries, sampled in the spring and early summer of 2013 and 2014 (table 4), were lower $\left(8 \pm 5 \mathrm{~kg} \mathrm{~d}^{-1}, \mathrm{n}=7\right)$. During the bloom period, dissolved-Mn benthic flux decreased relative to the pre-bloom period and varied between -6.12 and $430 \mu \mathrm{g}-\mathrm{Mn} \mathrm{m}^{-2} \mathrm{~d}^{-1}$ (mean of $282 \pm 124 \mu \mathrm{g}-\mathrm{Mn} \mathrm{m}^{-2} \mathrm{~d}^{-1}, \mathrm{n}=9$ ), converting to an areally lakeaveraged dissolved-Mn load to the lake water column of $56 \pm 25 \mathrm{~kg} \mathrm{~d}^{-1}$. In the final post-bloom period, dissolved-Mn benthic flux varied between 135 and $591 \mu \mathrm{g}-\mathrm{Mn} \mathrm{m}^{-2} \mathrm{~d}^{-1}$ (mean of $335 \pm 140 \mu \mathrm{g}-\mathrm{Mn} \mathrm{m}^{-2}$ $\mathrm{d}^{-1}, \mathrm{n}=9$ ). The associated dissolved-Mn benthic load to the lake water column was $67 \pm 28 \mathrm{~kg} \mathrm{~d}^{-1}$, again higher than the maximum riverine Mn loads estimated herein $\left(8 \pm 5 \mathrm{~kg} \mathrm{~d}^{-1}, \mathrm{n}=7\right)$. Unlike SRP, ammonia, and Fe, there was no clear rebound of Mn benthic flux in the final sampling weeks of the post-bloom period. 
Consistent with 2013, both positive and negative As fluxes were observed in 2014. In the prebloom period, dissolved-As benthic flux gradually decreased from positive to negative values, varying between 26.24 and $8.47 \mu \mathrm{g}$-As m ${ }^{-2} \mathrm{~d}^{-1}$ (mean of $4.41 \pm 13.33 \mu \mathrm{g}-\mathrm{As} \mathrm{m}^{-2} \mathrm{~d}^{-1}, \mathrm{n}=9$; table 14 ), an order of magnitude lower than Mn benthic flux. The mean As flux represents an areally averaged dissolved-As load to the lake water column (as As) of $0.9 \pm 2.7 \mathrm{~kg} \mathrm{~d}^{-1}$. By comparison, estimates of dissolved-As loads from the inlet tributaries, sampled in the spring and early summer of 2013 and 2014 (table 4), were lower $\left(4 \pm 3 \mathrm{~kg} \mathrm{~d}^{-1}, \mathrm{n}=7\right)$. During the bloom period, dissolved-As benthic flux further decreased relative to the pre-bloom period and varied between -39.33 and $-12.70 \mu \mathrm{g}-\mathrm{As} \mathrm{m}^{-2} \mathrm{~d}^{-1}$ (mean of -23.97 $\pm 9.82 \mu \mathrm{g}$-As m${ }^{-2} \mathrm{~d}^{-1}, \mathrm{n}=9$ ), converting to an areally lake-averaged dissolved-As load to the lake water column of $-4.8 \pm 2.0 \mathrm{~kg} \mathrm{~d}^{-1}$. In the final post-bloom period, dissolved-As benthic flux attained both negative and positive extremes, varying between $-47.94 \mu \mathrm{g}-\mathrm{As} \mathrm{m}^{-2} \mathrm{~d}^{-1}$ immediately following the end of the bloom to $70.56 \mu \mathrm{g} \mathrm{m}^{-2} \mathrm{~d}^{-1}$ only 3 weeks after (mean of $15.73 \pm 43.58 \mu \mathrm{g}-\mathrm{As} \mathrm{m}^{-2} \mathrm{~d}^{-1}, \mathrm{n}=9$ ). The associated dissolved As benthic load to the lake water column was $3.15 \pm 8.72 \mathrm{~kg} \mathrm{~d}^{-1}$, similar to the aforementioned maximum riverine As loads estimated herein $\left(4 \pm 3 \mathrm{~kg} \mathrm{~d}^{-1}, \mathrm{n}=7\right)$. During the post-bloom period, the rebound of As benthic flux occurred in the initial rather than final weeks of the post-bloom period, unlike SRP, ammonia, and Fe. Although benthic sources of As do not dominate riverine inputs as they do for SRP, ammonia, Fe, and Mn, it is important to note that As was the only solute in this study to exhibit a seasonal shift in the benthos as a source and a sink. This shorter-term response relative other solutes may be a useful factor in designing and monitoring TMDL programs for arsenic, if needed.

In the pre-bloom period, dissolved- $\mathrm{V}$ benthic flux was consistently negative, varying between -97.57 and $-14.88 \mu \mathrm{g}-\mathrm{V} \mathrm{m}^{-2} \mathrm{~d}^{-1}$ (mean of $-52.18 \pm 26.53 \mu \mathrm{g} \mathrm{m}^{-2} \mathrm{~d}^{-1}, \mathrm{n}=9$; table 14). The negative $\mathrm{V}$ flux represents dissolved-V loss from the lake water column to the lakebed (areally averaged as V loss, $-10.4 \pm 5.3 \mathrm{~kg} \mathrm{~d}^{-1}$ ). The subsequent bloom period generated similarly negative dissolved-V benthic flux varying between -125.05 and $-18.26 \mu \mathrm{g}-\mathrm{V} \mathrm{m}^{-2} \mathrm{~d}^{-1}$ (mean of $-61.86 \pm 40.81 \mu \mathrm{g}-\mathrm{V} \mathrm{m}^{-2} \mathrm{~d}^{-1}, \mathrm{n}=9$ ), converting to an areally lake-averaged dissolved-V loss from the water column to the lakebed $(-12.4 \pm$ $\left.8.2 \mathrm{~kg} \mathrm{~d}^{-1}\right)$. In the final post-bloom period, dissolved-V benthic flux was similar to those observed during the pre-bloom period and again consistently negative. Flux varied between -95.95 and -27.47 $\mu \mathrm{g}-\mathrm{V} \mathrm{m}^{-2} \mathrm{~d}^{-1}$ (mean of $-52.23 \pm 22.11 \mu \mathrm{g}-\mathrm{V} \mathrm{m}^{-2} \mathrm{~d}^{-1}, \mathrm{n}=9$ ). The associated dissolved $\mathrm{V}$ benthic loss from the lake water column was $-10.4 \pm 4.4 \mathrm{~kg} \mathrm{~d}^{-1}$. The predominantly negative $2014 \mathrm{~V}$ fluxes through all three sampling periods of varying $\mathrm{pH}$ were consistent with those observed in 2013. However, they again contrast the modeled positive, $\mathrm{pH}$-dependent $\mathrm{V}$ benthic flux for Lake Biwa, Japan, by Harita and others (2005), based on seasonal changes in water-column V. Aside from bathymetric and hydrodynamic differences between Lake Biwa (41 m average depth) and Upper Klamath Lake (2.5 m average depth), the site-specific discrepancy between the results is due to a lack of $\mathrm{pH}$ dependence on $\mathrm{V}$ flux in Upper Klamath Lake. That is, as $\mathrm{pH}$ increased during the bloom period, $\mathrm{V}$ benthic flux (presumably incurred by anion desorption) did not increase and in fact remained negative. We hypothesize that these flux differences may be due to differences in chemical speciation of $\mathrm{V}$ (adsorbate) and sediment (adsorbent) between lakes.

As observed in the 2013 spatial study, benthic fluxes for dissolved cobalt, nickel, copper, zinc, cadmium, and lead were at least three orders of magnitude lower than either dissolved iron or manganese fluxes (table 14). Although some of these dissolved trace metals (for example, cobalt, copper, and zinc) serve as essential micronutrients, they may also generate a toxicological response on primary production when they exist in the free-ion form at elevated concentrations. For example, Martin and Pedersen (2002) noted that treatment and removal of toxic trace metals from point sources flowing into mining-impacted Balmer Lake, Ontario, Canada, caused the lake to become more productive. With a greater carbon source from the water column to the lakebed, they hypothesized that benthic oxygen 
demand following enhanced pelagic primary production generated reducing conditions that remobilized other toxic elements like As. Although Martin and Pedersen (2002) observed this trend of increasing As benthic flux over multiyear time scales, the basic geochemical mechanisms are consistent with the temporal trends in As benthic flux observed here over weekly time scales. As noted with the 2013 results, there is no indication of a toxic response to elevated dissolved trace elements like copper and zinc.

\section{Dissolved (0.2- $\mu \mathrm{m}$ Filtered) Trace Elements in the Water Column in 2014}

Consistent with the discussion of water-column trace elements in 2013, this section will focus on a summary of data for dissolved iron ( $\mathrm{Fe})$, manganese ( $\mathrm{Mn})$, and arsenic (As). As previously mentioned, there is particular interest in these solutes as potentially limiting micronutrients or toxicants and concentration exceedances relative to recently revised water-quality standards. Although not discussed below, initial water-column concentrations for seven other trace elements are provided (table 15), all with biogeochemical significance, but without current water-quality implications for UKL. Should future concerns regarding these trace elements arise, this study provides initial data for reference, analysis, and modeling. For example, arsenic was not initially a focus of this study until recent revisions in water-quality standards in the State of Oregon.

For dissolved $\mathrm{Fe}$, concentrations varied between 5.48 and $42.40 \mu \mathrm{g}-\mathrm{Fe} \mathrm{L}^{-1}$ (overall mean of $21.02 \pm 9.23 \mu \mathrm{g}-\mathrm{Fe} \mathrm{L}^{-1}, \mathrm{n}=26$; table 15). Consistent with 2013 results, dissolved-Fe depletion in the lake water column was not observed in 2014. During the pre-bloom period, dissolved Fe exhibited a range from 5.48 to $26.81 \mu \mathrm{g}-\mathrm{Fe} \mathrm{L}^{-1}$ (mean of $14.29 \pm 7.12 \mu \mathrm{g}-\mathrm{Fe} \mathrm{L}^{-1}, \mathrm{n}=9$ ). During the subsequent bloom period, dissolved Fe varied between 15.82 and $34.47 \mu \mathrm{g}-\mathrm{Fe} \mathrm{L}^{-1}$ (mean of $21.18 \pm 6.46 \mu \mathrm{g}-\mathrm{Fe} \mathrm{L}{ }^{-1}$, $\mathrm{n}=8$ ). In the final post-bloom period, the highest dissolved-Fe concentrations were observed, ranging from 13.59 to $42.40 \mu \mathrm{g}-\mathrm{Fe} \mathrm{L}^{-1}$ (mean of $27.59 \pm 8.91 \mu \mathrm{g}-\mathrm{Fe} \mathrm{L}^{-1}, \mathrm{n}=9$ ). In the bloom and post-bloom periods, Fe may repartition and remobilize as cyanobacterial cells senesce.

Dissolved $\mathrm{Mn}$ in the 2014 temporal study exhibited a range from 0.05 to $10.26 \mu \mathrm{g}-\mathrm{Mn} \mathrm{L}^{-1}$ (overall mean of $2.05 \pm 2.10 \mu \mathrm{g}-\mathrm{Mn} \mathrm{L}^{-1}, \mathrm{n}=26$; table 15). As with dissolved $\mathrm{Fe}$, dissolved-Mn depletion in the lake water column was not observed in 2014. During the pre-bloom period, dissolved Mn exhibited a range from 0.05 to $2.98 \mu \mathrm{g}-\mathrm{Mn} \mathrm{L}^{-1}$ (mean of $1.02 \pm 1.04 \mu \mathrm{g}-\mathrm{Mn} \mathrm{L}^{-1}, \mathrm{n}=9$ ). Dissolved $\mathrm{Mn}$ in the subsequent bloom period varied between 0.72 and $3.96 \mu \mathrm{g}-\mathrm{Mn} \mathrm{L}^{-1}$ (mean of $1.69 \pm 1.07 \mu \mathrm{g}$ $\mathrm{Mn} \mathrm{L}^{-1}, \mathrm{n}=8$ ). Again, similar to dissolved $\mathrm{Fe}$, the highest dissolved-Mn concentrations were observed in the post-bloom period, ranging from 0.42 to $10.26 \mu \mathrm{g}-\mathrm{Mn} \mathrm{L}^{-1}$ (mean of $3.35 \pm 2.95 \mu \mathrm{g}-\mathrm{Mn} \mathrm{L}^{-1}, \mathrm{n}=$ 9). Analogous to $\mathrm{Fe}$, the essential micronutrient $\mathrm{Mn}$ may also repartition and remobilize once a cyanobacterial peak is achieved.

Dissolved As varied between 2.79 and $11.94 \mu \mathrm{g}$-As L ${ }^{-1}$ (overall mean of $6.78 \pm 2.65 \mu \mathrm{g}-\mathrm{As} \mathrm{L}^{-1}$, $\mathrm{n}=26$; table 15), all well above detection limits $\left(>0.01 \mu \mathrm{g}\right.$-As $\left.\mathrm{L}^{-1}\right)$. During the pre-bloom period, dissolved As increased, but among the three periods, the lowest dissolved-As concentrations were observed during this period, varying between 2.79 and $6.44 \mu \mathrm{g}-\mathrm{As} \mathrm{L}^{-1}$ (mean of $4.12 \pm 1.18 \mu \mathrm{g}-\mathrm{As} \mathrm{L}^{-1}$, $\mathrm{n}=9$ ). Consistent with 2013 water-column results, dissolved As within the subsequent bloom period continued to increase in concentration and variability, from 5.43 to $11.94 \mu \mathrm{g}-\mathrm{As} \mathrm{L}^{-1}$ (mean of $8.79 \pm$ $2.68 \mu \mathrm{g}$-As $\mathrm{L}^{-1}, \mathrm{n}=8$ ). The post-bloom period displayed a contrast relative to the previous two periods for dissolved-As concentrations, which decreased during the post-bloom period from 10.09 to $6.16 \mu \mathrm{g}$ As $\mathrm{L}^{-1}$ (mean of $7.64 \pm 1.19 \mu \mathrm{g}$-As L ${ }^{-1}, \mathrm{n}=9$ ). As mentioned in the previous section, dissolved-As benthic flux decreased between the pre-bloom and bloom periods (table 14) then generated the highest positive fluxes in the post-bloom period. This inverse relationship between water-column As and benthic flux is consistent with 2013 As results (tables 6 and 7), although greater spatial coverage in 
2013 generated greater parameter variability for a given date. In summary, as water-column As increased during the spring and early summer (the pre-bloom and bloom periods), As benthic flux coincidentally decreased. Conversely, as water-column As decreased during mid to late summer (the post-bloom period), As benthic flux increased. This inverse relationship is reasonable because watercolumn concentrations that overlay the lakebed inversely affect concentration gradients that are used to calculate diffusive flux (see "Methods" section). The relationship generates three desirable water-quality management implications for As. First, the interdependence between water-column As and benthic flux is apparent within a seasonal time scale, not observed for macronutrients like SRP and ammonia. Multiyear to decadal response times for macronutrients like SRP and ammonia have been reported (Kuwabara and others, 2012a). Second, riverine As loading plays a more important role in solute transport relative to macronutrients like SRP and ammonia, where lake water-column loading is principally from the lakebed (table 4), so the effects of regulations on riverine and other As point sources to the lake may be more quickly detected. Finally, the lakebed currently serves as both a solute source and sink that mitigates or buffers water-column As concentrations.

Water-Column Chlorophyll in 2014

As with other ancillary parameters discussed above, water-column chlorophyll places the geochemical and benthic invertebrate results in the context of phytoplankton dynamics within the lake. In fact, water-column chlorophyll concentrations during the 2014 temporal study identified three distinct periods within the 27-week sampling period that aggregate and facilitate comparison of geochemical data. For example, overall, the water-column chlorophyll concentrations varied between 4.5 and $257 \mu \mathrm{g} \mathrm{L}^{-1}$ (mean of $68.8 \pm 80.2 \mu \mathrm{g} \mathrm{L}^{-1}, \mathrm{n}=27$; table 11). However, the pre-bloom period between April 16 and June 11, 2014, generated a limited range of water-column chlorophyll, from 4.5 to $66.9 \mu \mathrm{g} \mathrm{L}^{-1}$ (mean of $15.9 \pm 19.7 \mu \mathrm{g} \mathrm{L}^{-1}, \mathrm{n}=9$ ). During the subsequently identified bloom period between June 18 through August 13, 2014, water-column chlorophyll varied between 67.0 and $257 \mu \mathrm{g}$ $\mathrm{L}^{-1}$ (mean of $164 \pm 69.1 \mu \mathrm{g} \mathrm{L}^{-1}, \mathrm{n}=9$ ). The third and final post-bloom period between August 20 and October 16, 2014, generated expectedly lower water-column chlorophyll that ranged from 6.2 to 45.0 $\mu \mathrm{g} \mathrm{L}^{-1}$ (mean of $24.9 \pm 13.5 \mu \mathrm{g} \mathrm{L}^{-1}, \mathrm{n}=9$ ). Independent monitoring of water-column chlorophyll at another open-lake site in Upper Klamath Lake near the profiler deployment site ON01 yielded similar results, with an overall range from 6.4 to $283 \mu \mathrm{g} \mathrm{L}^{-1}$ (mean of $76.3 \pm 71.6 \mu \mathrm{g} \mathrm{L}^{-1}, \mathrm{n}=21$ ) between June 5 and October 14, 2014 (U.S. Geological Survey, 2016). The pre-bloom data between June 5 and 11, 2014, varied between 9.1 and 58.1 $\mu \mathrm{g} \mathrm{L}^{-1}$ (mean of 33.6 $\pm 34.6 \mu \mathrm{g} \mathrm{L}{ }^{-1}, \mathrm{n}=2$ ). During the subsequent bloom period between June 16 through August 11, 2014, water-column chlorophyll varied between 39.0 and $283 \mu \mathrm{g} \mathrm{L}^{-1}$ (mean of $126 \pm 74 \mu \mathrm{g} \mathrm{L}^{-1}, \mathrm{n}=9$ ). The post-bloom period between August 18 and October 14, 2014, generated water-column chlorophyll that ranged from 6.4 to $122 \mu \mathrm{g} \mathrm{L}^{-1}$ (mean of $\left.35.1 \pm 36.4 \mu \mathrm{g} \mathrm{L}^{-1}, \mathrm{n}=9\right)$.

Water-column pheophytin varied between 1.42 and $156.06 \mu \mathrm{g} \mathrm{L}^{-1}$ (overall mean of $21.12 \pm$ $37.75 \mu \mathrm{g} \mathrm{L}^{-1}, \mathrm{n}=27$; table 11). By comparison, the pre-bloom period generated a pheophytin range from 1.42 to $5.74 \mu \mathrm{g} \mathrm{L}^{-1}$ (mean of $2.86 \pm 1.22 \mu \mathrm{g} \mathrm{L}^{-1}, \mathrm{n}=9$ ). In the subsequent bloom period, pheophytin varied between 11.59 and $156.06 \mu \mathrm{g} \mathrm{L}^{-1}$ (mean of $55.22 \pm 51.37 \mu \mathrm{g} \mathrm{L}{ }^{-1}, \mathrm{n}=9$ ). The final post-bloom period generated lower pheophytin concentrations that ranged between 1.60 and $18.46 \mu \mathrm{g} \mathrm{L}^{-1}$ (mean of $5.28 \pm 5.10 \mu \mathrm{g} \mathrm{L}^{-1}, \mathrm{n}=9$ ).

As mentioned above for benthic chlorophyll, the ratio of water-column chlorophyll to the sum of pheophytin plus water-column chlorophyll serves as a coarse indicator of the reproductive status of the dynamic phytoplankton communities in 2014 (Thompson and others, 1981; Light and John, 1998; U. S. Environmental Protection Agency, 2000). Over the entire temporal study, the ratio was expectedly 
higher and less variable than benthic chlorophyll determined in 2013 (table 8) and in previous studies (Kuwabara and others, 2009; Kuwabara and others, 2012a), varying between 0.62 and 0.92 (overall mean of $0.80 \pm 0.09, \mathrm{n}=27$; table 11). Ratios during the pre-bloom period range from 0.69 to 0.92 (mean of $0.79 \pm 0.07, \mathrm{n}=9$ ). In the subsequent bloom period, those ratios varied between 0.62 and 0.90 (mean of $0.78 \pm 0.11, \mathrm{n}=9$ ). The final post-bloom period generated ratios with a range from 0.68 to 0.92 (mean of $0.83 \pm 0.09 \mu \mathrm{g} \mathrm{L}^{-1}, \mathrm{n}=9$ ). In contrast to previous benthic-chlorophyll measurements, all 27 watercolumn ratios were $>0.5$ (that is, greater chlorophyll than degraded pheopigments). However, somewhat unexpectedly, there was no difference in these ratios between the three sampling periods. Perhaps, transport and turnover of benthic chlorophyll mitigate anticipated growth-phase effects. Geochemical and biological data reported herein provide indication of the interannual variability of interdependent geochemical and biological parameters as phytoplankton succession involving both nitrogen-fixing and non-nitrogen-fixing cyanobacteria occur over multiple time scales (Kann, 2006; Kann, 2010). It will be useful to compare water-column trends with the timing of phytoplankton taxonomic succession in Upper Klamath Lake when taxonomic data for 2013 and 2014 become available.

\section{Benthic Invertebrate Assemblages in 2014}

Average invertebrate density over the 2014 study period was $19,796 \pm 14,056$ inds $\mathrm{m}^{-2}(\mathrm{n}=27)$ (tables 16 and 17). Oligochaeta, Chironomidae and Hirudinea represented 66.6, 19.0, and 14.2 percent, respectively, of all organisms identified. Average taxon richness per sample (mean of 5 Ekman grabs) was $19.0 \pm 3.7(n=27)$ and ranged from 13.4 to 24.6 . Total taxon richness was $45 ; 13$ were oligochaetes, 13 were chironomids, and 7 were hirudineans.

Invertebrate data were partitioned into three time periods, which were identical to those used to summarize the physicochemical data. Average invertebrate densities during each of the three collecting periods were similar for the first two periods but were higher in the final sampling period. Total densities for the pre-bloom, bloom, and post-bloom periods were $10,643 \pm 2,308$ inds $\mathrm{m}^{-2}(\mathrm{n}=21)$, $12,668 \pm 4,040$ inds $\mathrm{m}^{-2}(\mathrm{n}=21)$, and 36,078 $\pm 13,071$ inds $\mathrm{m}^{-2}(\mathrm{n}=21)$, respectively. Percentage of oligochaetes decreased from 70 percent during the first period to 55 percent during the middle period and then increased to 74 percent during the final period. Chironomids comprised a higher than typical percentage of the assemblage during the middle period, increasing from 18 percent to 26 percent and then deceasing to 12 percent during the last period. Percentage abundance of hirudineans was somewhat similar to chironomids, beginning at 11 percent, then increasing to 18 percent, and finally decreasing to 13 percent in the final period.

\section{Invertebrate Composition Comparison Between 2013 and 2014}

The estimate of mean densities for benthic invertebrates during 2013 and 2014 were 12,610 and 19,796 inds $\mathrm{m}^{-2}$, respectively. The difference likely was a function of the time period over which samples were collected ( 3 collecting dates in the beginning of summer in 2013 compared to 27 collecting dates during 2014) and the spatial scale over which samples were collected (21 sites distributed throughout the lake and among three different habitats in 2013 compared to a single openlake site sampled on 27 consecutive weeks in 2014). The three sampling dates in 2013 were in late spring and early summer, coincident with the development of the summer AFA bloom. In contrast, samples in 2014 were collected from late spring through summer and into early autumn. As previously mentioned, weekly sampling in 2014 was partitioned into three periods based on water-column chlorophyll measurements: the pre-bloom period (April 15 through June 10, 2014), the bloom period (June 17 through August 13, 2014), and the post-bloom period (August 20 through October 16, 2014). Average invertebrate density was similar $\left(\sim 12,000\right.$ inds $\left.\mathrm{m}^{-2}\right)$ among the three collecting dates in 2013 
and the first two collecting periods in 2014. The collecting dates in 2013 and the first two periods in 2014 represent a somewhat similar seasonal period. Densities increased dramatically during the last sampling period in 2014. The increase in invertebrate density was represented by a fourfold increase in oligochaetes and a twofold increase in hirudineans. Helobdella hirudineans brood their young; consequently, it is apparent from tables 9 and 16, which show an increase in undetermined Helobdella hatchlings, that their population increases during this part of the season. Chironomids also increased by approximately 25 percent during the third period.

\section{Invertebrate Composition Comparison to Previous Studies}

Relatively few studies on the distributions of benthic invertebrates in Upper Klamath Lake have been completed prior to ours. Nevertheless, the few that have been completed allow a coarse assessment of whether total benthic invertebrate densities have dramatically changed over time and (or) whether patterns in abundances among major taxa have changed. One of the earliest studies was by Davis and others (1938) as reported in Hazel (1969). They reported approximately 1,262 chironomids $\mathrm{m}^{-2}$, almost identical to the 1,264 dipterans (almost all of which were Chironomidae) reported by Hazel (1969). We found total density and relative densities of oligochaetes, hirudineans, and chironomids during our 2013 to be remarkably similar to those reported by Hazel (1969) approximately 50 years ago.

Season and time period over which benthic invertebrates are collected can have a large influence on estimated densities. As noted above, average densities during the studies in 2013 and 2014 differed, with densities in general being much higher during the 2014 study than in the 2013 study. Kuwabara and others (2009), using the same sampling and processing techniques as we used in 2013 and 2014, found similar total density $\left(\sim 10,000\right.$ inds $\left.\mathrm{m}^{-2}\right)$ as we found in $2013\left(\sim 12,000\right.$ inds $\left.\mathrm{m}^{-2}\right)$. Both studies sampled from late spring to the end of July or beginning of August. In comparison, Wood and others (2013), using the same collecting and processing methods, found densities $\left(\sim 20,000\right.$ inds $\left.^{-2}\right)$ almost identical to our 2014 study. Wood and others (2013) and our 2014 study sampled from late spring through, at least, the beginning of October.

\section{Biological Solute Efflux-Soluble Reactive Phosphorus (2011-2015)}

A total of 470 measurements were completed from autumn 2011 through autumn 2015 to evaluate the release of soluble reactive phosphorus (SRP) from benthic invertebrates. From autumn 2011 through 2013, invertebrates were collected and assessed for the release of nutrients in late spring and early autumn. Invertebrates were assessed three times in 2015: May 7, July 31, and October 8, 2015. In general, invertebrates were targeted that were (1) most widely distributed, (2) most abundant, and (3) represented the larger of the taxa available, with the assumption that larger and more abundant organisms would contribute the most to lake nutrient loading.

The release of SRP varied among taxa (table 18). In general, the highest rates of per-taxon efflux were among the Hirudinea. Release of SRP by the hirudinean Mooreobdella far exceeded all other taxa on a per-individual basis, likely because it is approximately 20-50 times larger than most other taxa typically collected in the benthic grabs. Fourth instar chironomid Cryptochironomus released substantially less SRP than Mooreobdella and only released slightly higher amounts than the remaining hirudinean species assessed.

The contribution of SRP to the water column by any one species is a function of its rate of efflux and its density. The species-specific rate of efflux is a function of its life-history stage and potentially also a function of water temperature. An organism's density is a function of its life-history characteristics and other biotic interactions (for example, competition and predation). The hirudinean Helobdella nr. bowermani and the chironomid Procladius exceed other taxa by approximately a factor 
of 2 to 4 in their respective population's total contributions of SRP to the water column. The most frequently encountered large chironomid Chironomus plumosus released SRP amounts that differed as a function of its life-history stage. C. plumosus released several times more SRP as a fourth instar compared to a third instar larva.

The average density of the taxa tested, based on the 2013 benthic data, was approximately 6,700 inds $\mathrm{m}^{-2}$ (table 9). This represents approximately one-half the average total density of invertebrates collected from a square meter of lake bottom, which was around 12,000 inds $\mathrm{m}^{-2}$ in 2013 . The sum of the product of individual SRP efflux estimates per taxon and average density per taxon yields $3.3 \mathrm{mg}-\mathrm{P}$ $\mathrm{m}^{-2} \mathrm{~d}^{-1}$. We assume this estimate of invertebrate efflux can be at least doubled, to around $6.5 \mathrm{mg}-\mathrm{P} \mathrm{m}{ }^{-2}$ $\mathrm{d}^{-1}$, because it represents the efflux of only one-half the benthic invertebrates per square meter found during the 2013 spatial sampling. Also, our samples were sieved using the typical $500-\mu \mathrm{m}$ mesh so that they would be as comparable as possible to other benthic studies relative to estimating density. We know that many benthic organisms pass through a 500- $\mu \mathrm{m}$ mesh sieve; therefore, our density estimates

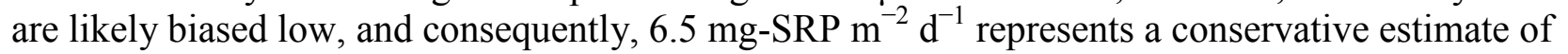
benthic invertebrate SRP efflux to the lake water column.

A number of studies have estimated phosphorus release by aquatic invertebrates. Unfortunately, there is little similarity in the methods used or how release rates are reported. Regardless, once estimates are converted to common units, the release of SRP by UKL benthic invertebrates was not dissimilar to estimates by other studies. Fukuhara and Sakamoto (1987) estimated SRP release by fourth instar Chironomus plumosus to be $1.183 \mu \mathrm{g}-\mathrm{P}$ ind ${ }^{-1} \mathrm{~d}^{-1}$, similar to our $0.843 \mu \mathrm{g}-\mathrm{P}$ ind $\mathrm{d}^{-1} \mathrm{~d}^{-1}$. Gardner and others (1981) found very similar rates $\left(0.729 \mu \mathrm{g}-\mathrm{P}\right.$ ind $\left.\mathrm{d}^{-1} \mathrm{~d}^{-1}\right)$ when evaluating three species of Chironomus including C. plumosus. Substantially higher rates $\left(1.84 \mu \mathrm{g}-\mathrm{P}\right.$ ind ${ }^{-1} \mathrm{~d}^{-1}$ and $4.86 \mu \mathrm{g}-\mathrm{P}$ ind $^{-1}$ $\mathrm{d}^{-1}$ ) were estimated by Devine and Vanni (2002); however, they assumed their estimates were higher than other studies because of the presence of food and possibly because their experiments were completed at higher temperatures than comparative studies.

The effect of temperature on nutrient release by invertebrates has been mixed. Gallepp (1979) found that SRP release increased by a factor of 10 as temperature varied from 10 to $20^{\circ} \mathrm{C}$, although this magnitude of effect has infrequently been detected by subsequent research. Our experiments were performed at ambient lake temperatures, which were $14-15{ }^{\circ} \mathrm{C}$ in the spring and autumn and $20{ }^{\circ} \mathrm{C}$ at the end of July. Our 2015 estimates for Chironomus plumosus indicated that there potentially was a temperature effect. SRP release was $1.089 \pm 1.79337 \mu \mathrm{g}-\mathrm{P}$ ind $^{-1} \mathrm{~d}^{-1}(\mathrm{n}=37)$ on May 7,2015 , at $14{ }^{\circ} \mathrm{C}$; $1.305 \pm 1.159 \mu \mathrm{g}-\mathrm{P}$ ind $^{-1} \mathrm{~d}^{-1}(\mathrm{n}=25)$ on July 31,2015 , at $20{ }^{\circ} \mathrm{C}$; and $0.533 \pm 0.676 \mu \mathrm{g}-\mathrm{P}$ ind ${ }^{-1} \mathrm{~d}^{-1}(\mathrm{n}=22)$ on October 8,2015 , at $14{ }^{\circ} \mathrm{C}$. However, heterogeneous variances among experiments preclude a definitive conclusion. Although all individuals tested were fourth instar larvae, other seasonal differences in the populations and water-quality conditions of the lake likely influence release rates as well.

Estimates of SRP release by oligochaetes have also been variable. Postolache and others (2006) estimated rates for tubificids that ranged from 0.094 to $0.144 \mu \mathrm{g}-\mathrm{P}$ ind $^{-1} \mathrm{~d}^{-1}$, and Ji and others (2015) estimated values ranging from $0.002 \mu \mathrm{g}-\mathrm{P}$ ind ${ }^{-1} \mathrm{~d}^{-1}$ for Capitella to $0.415 \mu \mathrm{g}-\mathrm{P}$ ind ${ }^{-1} \mathrm{~d}^{-1}$ for Limnodrilus hoffmeisteri. The above values are similar to the values we estimated for resident UKL oligochaetes (table 18). To our knowledge, our estimates of SRP release by hirudineans are unique. They span a substantial range in magnitude, which is clearly a function of size, from the very large Mooreobdella to the much smaller Helobdella spp.

Although all lake-dwelling organisms contribute to nutrient cycling (for example, bacteria, phyto- and zooplankton, fish, birds), benthic invertebrates represent an obvious linkage between lake sediments and the water column (Sereda and Hudson, 2011). Aside from their importance in the trophic 
transfer of energy and solutes from lower trophic levels to higher trophic levels, elevated densities of benthic invertebrates have the potential to increase the benthic flux of solutes (Kuwabara and others, 2009). Benthic invertebrate assemblages may enhance dissolved nutrient (or toxicant) diffusion across the sediment-water interface by (1) modifying diffusion-layer thicknesses and permeability through bioturbation, (2) enhancing advective flow across the interface through bioirrigation, and (3) excreting or expelling dissolved or particulate solutes directly into the overlying water column (Boudreau and Jorgensen, 2001). We only evaluated benthic invertebrate SRP efflux via excretion for approximately 15 different taxa. Once species-specific efflux was scaled by species density, the results suggest that benthic invertebrates potentially contribute 1.5 times the amount of SRP $\left(6.5 \mathrm{mg}-\mathrm{P} \mathrm{m} \mathrm{m}^{-2} \mathrm{~d}^{-1}\right)$ to the water column of Upper Klamath Lake as diffusive flux alone $\left(4.3 \mathrm{mg}-\mathrm{P} \mathrm{m}^{-2} \mathrm{~d}^{-1}\right)$.

\section{5-Physical (Advective) Solute Transport and Particle Dynamics}

\section{Physical (Advective) Solute Transport}

Previous estimates of heat transfer near the sediment-water interface suggested the potential importance of physical (hydrologic) transport of solutes between the lakebed and overlying water column (Kuwabara and others, 2009). To examine this process further, piezometers were deployed at all 18 open-lake and littoral-zone sites studied in 2013, and at an additional seep/spring site (SPR, fig. 1) in proximity of visible groundwater inputs at the lakeshore. Piezometers were fitted with pressure transducers to measure head in the lake and $1.5 \mathrm{~m}$ below the lakebed. In addition, a set of 3 temperature loggers was deployed at 6 of the 19 piezometer sites (see "Methods" section). Because of an unknown combination of piezometer-pipe failure at threaded connections and (or) vandalism, only 4 temperaturelogger sets and 15 piezometers were retrievable from which to collect and analyze data (table 19). The pressure transducer installations, however, did not perform as designed in that the vertical positions of the instruments apparently shifted slightly in response to external influences such as wave action. These shifts were of a magnitude similar to the head differences between the lake and underlying sediments. Because of this, the magnitude and direction of vertical head gradients were deemed unreliable. This issue, however, did not significantly affect temperature data. Consequently, advective groundwater flux estimates presented herein are based solely on temperature data.

Heat is a well-established tracer for accurately estimating water fluxes through sediments, based on measured spatial and temporal sediment-temperature patterns (Bredehoeft and Papadopulos, 1965; Stallman, 1965; Lapham, 1989; Constantz and others, 2003; Stonestrom and Constantz, 2003; Anderson, 2005; Constantz, 2008; Essaid and others, 2008; Rahimi and others, 2015). Modeling for this study used the program 1DTempPro V2 (Koch and others, 2015) to generate advective flux estimates based on temperature-logger data from four UKL sites, without use of tranducer data (that is, without imposed hydraulic conductivity or heads in running the model). Because model inputs for lakebed sediment characteristics were a potential source of uncertainty for the output, in this case discharge, the model was run for all four sites (SPR, LN01, ON01, and LS01) to examine the effect of changing the modeled porosity over a range from 0.7 to 0.9 , as well as the effects of thermal conductivity and heat capacity (Stonestrom and Constantz, 2003). The inclusion of groundwater discharge consistently improved the model fit to the temperature-logger data, relative to a "no discharge" assumption (table 19). Estimated groundwater discharge into the lake continuously decreased from spring to autumn and was negative during the third sampling period in September. Given decreasing lake elevations over the period of temperature-logger deployments, the apparent reduction in groundwater inflow and reversal of direction, although noted in previous heat-flux estimates (Kuwabara and others, 2009), would not be expected if lake water-column hydraulic head solely regulated groundwater input to the lake. Although 
not used in this modeling effort, a low hydraulic conductivity $\left(0.0006 \mathrm{~m} \mathrm{~d}^{-1}\right)$ was determined for site LN01 using a slug-test method (Bouwer and Rice, 1976), suggesting lower, perhaps negligible fluxes relative to those determined by heat-flow modeling. In addition, Gannett and others (2007) reported a mean groundwater discharge into Upper Klamath Lake of 350 cubic feet per second $\left(\mathrm{ft}^{3} \mathrm{~s}^{-1}\right)\left(8.6 \times 10^{8}\right.$ $\mathrm{L} \mathrm{d}^{-1}$ ) using a water mass-balance model. Assuming a lake projected area of $249 \mathrm{~km}^{2}$, that water flux is equivalent to a mean discharge from the lakebed of $0.003 \mathrm{~m} \mathrm{~d}^{-1}$. By comparison, the mean discharge from the heat-flow modeling was $0.005 \mathrm{~m} \mathrm{~d}^{-1}(\mathrm{n}=33$, table 19). Given the spatial and temporal variability of the heat-flow derived discharges, caution should be taken if these results (table 19) are extrapolated into lakewide fluxes. Over the porosity range from 0.7 to 0.9 (table 19), estimates (both positive and negative) of the temperature-derived advective fluxes for SRP are of comparable magnitude in absolute value to diffusive-flux and macroinvertebrate efflux (all positive but spanning the same orders of magnitude). It is therefore recommended that solute advective flux as a potentially important transport process be examined for possible integration into existing and future water-quality models (for example, TMDL models).

Based on challenges faced in these initial groundwater-advection investigations, it is recommended in future studies that temperature-logger sets be deployed at every piezometerdeployment site so comparative estimates can be made. Greater numbers of temperature loggers per deployment set at each site may also be advisable. Three temperature loggers were used here for each set, whereas a previous deployment at one mid-lake site used five (Kuwabara and others, 2009). Because both the piezometers and temperature logger sets are highly visible (as required for boating safety), it is also suggested that some security measures be adopted, such as visual monitoring from the shore or by other research collaborators sampling the lake, or remote transmission of data with appropriate alarms. It may also be useful to directly determine lakebed thermal properties (for example, thermal conductivity and volumetric heat capacity) that were empirically derived as input for heat-flow modeling. To confirm transducer depths within the piezometer and lake (and most importantly their relative positions), precise water depths in both the piezometer and the stilling well should be measured to a common datum at each site at initial deployment, before and after instrument removal and replacement during site visits, and possibly at prescribed periods during deployment. Transducer removal and replacement during piezometer deployments should be kept to a minimum.

\section{Organic Aggregation and Settling in Upper Klamath Lake}

As indicated above, the overall study clearly focused on biogeochemical processes near the sediment-water interface that may affect solute transport and phytoplankton dynamics in the lake. However, the authors also recognized that other physical processes might also be of management and modeling relevance. For example, as suspended particles with biogenic origin aggregate and settle to a lakebed, there is a potential for heterotrophic degradation of this settled organic matter to alter redox conditions in the lake water column. An initial examination of suspended-particle characteristics was therefore conducted in 2015 using an In-situ Settling Velocity Instrument (INSSEV-LF) to better understand changing particle characteristics and settling velocities during the AFA-bloom period, at an open-lake and littoral-zone site near the surface and lakebed. This work involved different protocols, equipment, background literature, and terminology than the biogeochemistry sections presented herein. So to aid the reader in referencing and following the discussion of this complementary study, a somewhat independent discussion of this work is provided below. For this work, the term "floc" refers to suspended particles that may aggregate or disaggregate to change in size, composition, and settling velocity. 


\section{Overview of Particle Aggregation and Settling}

A high proportion of biological matter, which can vary both spatially in the lake and seasonally, dominates suspended particulate matter in Upper Klamath Lake (UKL). Although the amount of organic matter in suspended particulates was not directly assessed during this project, Wood and Gartner (2010) found the average organic fraction of the suspended matter to be as high as 77 percent during algal bloom conditions (such as July 2015) in UKL. It is possible that the organic matter content in UKL is lower than this value during pre- and post-cyanobacteria-bloom conditions (that is, early May 2015 and October 2015, respectively). Any remaining suspended particles resident within UKL would include fine, cohesive sediment that includes silts and clays and possibly even coarser fragments.

Particulate matter which is predominantly organic, will tend to behave as agglomerates, as opposed to inert solitary independent particles. This is very similar to the process of flocculation, whereby interparticle forces attract these cohesive particles to one another (for example, Mietta and others, 2009) and form flocs (for example, Manning and others, 2011; Mehta, 2014) composed of the particles and thus contain interparticle voids. As flocs grow in size, they trap more pore water within the floc compositional matrix, which means floc effective density $\rho_{\mathrm{e}}$ (that is, bulk density less the water density) generally decreases (Tambo and Watanabe, 1979). Although large flocs have lower effective densities than their constituent particles, they also exhibit significantly quicker settling velocities (Ws), a result of a Stokes' law relationship between floc sizes (D) and settling velocity (Ws; Dyer and Manning, 1999). This means that the flocs, which comprise a floc population, may exhibit individual floc sizes, settling velocities, and densities that range over three to four orders of magnitude (for example, Manning and others, 2013).

The term "floc" is commonly reserved for electrochemically agglomerated clay mineral particles. When they contain organic detritus greater than 5-10 percent by weight, floc properties are affected: there can be biopolymeric adhesion in addition to electrochemical cohesion, density can be reduced owing to the lower weight of organic matter, and porosity can increase. When the organic content increases to 30-40 percent, the agglomerates are commonly called "organic aggregates" (for example, Gowland and others, 2007; Mehta and others, 2009), and this terminology will be used (where relevant) in this report; alternatively, they are also known as "biochemical aggregates." However, the parameterized terms "macrofloc" (D $>160 \mu \mathrm{m})$ and "microfloc" $(\mathrm{D}<160 \mu \mathrm{m})$ will still be used to describe the relative properties of each organic aggregate fraction. The density and yield strength of organic aggregates (up to about 80-90 percent organic content) have been found to vary monotonically with organic content (see Gowland and others, 2007). Their study assessed suspended particulate matter with organic matter ranging from 0 to 82 percent. Furthermore, when Mehta and others (2009)

compared the dry density and organic content of suspended sediments in Lake Apopka (central Florida), where organic contents of the suspended matter reached 96 percent, with a wide range of mineral sediments, the highly organic sediments closely followed the same trend as predominantly mineral sediments, but the organic sediments were much weaker in terms of yield stress (the value of stress at which a material ceases to behave elastically).

UKL is a freshwater system with highly organic suspended matter. Therefore, it can logically be speculated that the bonding of any organic aggregates (predominantly cyanobacterial colonies in UKL) are primarily biologically based (for example, Kranck and Milligan, 1992; Wolanski, 2007), as opposed to classical physical cohesion (that is, electrostatic bonding observed in more brackish waters). This biocohesion was first observed in flocs by Eisma (1986) in the early 1980s and more recently in numerous freshwater aquatic environments across the United States, for example, Lake Apopka in central Florida (Mehta and others, 2009) and the Sacramento-San Joaquin River Delta in northern California (Manning and Schoellhamer, 2013). To reiterate, when organic particles dominate the suspended particulates, the 
role of electrochemical cohesion is limited and flocculation is thus not an appropriate term; hence, we use the term "biochemical/organic aggregates", or "organic flocs," for any such agglomerates formed. Mehta and others (2015) report that data from both Lake Okeechobee and Lake Apopka, Florida, surprisingly suggest that organic-rich aggregates follow fractal laws developed for mineral flocs (see Kranenburg, 1994). Mehta and others (2015) concluded that the variation of yield stress with the organic aggregate volume fraction appears to conform to fractal characterization commonly invoked for mineral sediment flocs, consistent with a mean fractal dimension value of 2.55.

Bio-cohesion within UKL is most probably facilitated through the presence of extracellular polymeric substances (EPS). EPS are high-molecular-weight compounds that are normally secreted by algal microorganisms (Tolhurst and others, 2002) and are mostly composed of polysaccharides (for example, mucopolysaccharides, exopolysaccharides) and proteins. In muddy aquatic environments such as estuaries, these sticky EPS biofilms are regarded as highly effective stabilizers of muddy sediments (de Brouwer and others, 2005; Gerbersdorf and others, 2009; Grabowski and others, 2011; Malarkey and others, 2015; Parsons and others, 2016). EPS are the principle constituents that determine the physiochemical properties of a biofilm and provide the major portion of a biofilm's total organic matter. Therefore, in a lake that is dominated by high organic content (such as UKL), it is highly probable that there are quite high levels of EPS present (when compared to typical estuarine locations), and this would enhance any biochemical aggregation of the suspended matter.

For water bodies such as small and deep lakes in which wind-driven mixing does not resuspend the particulate matter (whether it be sediment that is either predominantly mineral or organic based), measurements of settling velocity, size, and density in a test column may be artifacts of the measurement technique. In such a body of water, gravitational settling has a lesser meaning if the aggregates are not resuspended on a regular basis. However, for environments such as large, shallow lakes (for example, UKL), a mean circulation (that is, currents) can develop in these environments (for example, owing to wind-water surface interaction), and organic aggregates are much more easily resuspended than heavier mineral flocs. These resultant hydrodynamics (although it be modest by tidal aquatic environment standards) could easily set up interparticle collisions such as those through differential settling effects (Lick and others, 1993; Lick and Lick, 1988). Although cyanobacterial colonies can grow organically, these hydrodynamic mechanisms can potentially stimulate and further enhance the resultant organic aggregate/colony growth.

The size and mass of suspended organic aggregates determines their settling velocity, which in turn affects how long suspended particles remain in suspension and the clarity of the water column. These organic aggregate parameters also govern aggregate mass transport (Baugh and Manning, 2007; Manning and Dyer, 2007). As the bloom converges on maximum phytoplankton densities, senescing cells can readily collide and potentially aggregate into flocculant particles (that is, flocs) with elevated settling velocity.

As organic aggregates settle to a lakebed, there is a potential for any heterotrophic degradation of this settled organic matter to alter redox conditions in the lake water column, although this was not assessed in this study. Heterotrophic degradation can release bioavailable nutrients into the water column, a process that is more aligned with this study. It is therefore necessary to determine how much biochemical aggregation of the organic suspended matter/particles occur in UKL before, during, and after the annual algal bloom. The size, settling velocity, and effective density of individual organic aggregates can be used to develop numerical models of nutrient transport in dissolved and particulate phases. This research is part of a larger Bureau of Reclamation (Reclamation) project for the study of nutrient transport in Upper Klamath Lake, Oregon. 
Three surveys were conducted in UKL is 2015 as a collaboration between the USGS, Reclamation, and H.R. Wallingford (A.J. Manning, written commun., 2016) to measure aggregate diameter, settling velocity, and density with a specialist video camera; we summarize the organic aggregate observations results in this section.

\section{Particle Aggregation and Settling Results}

Previous studies by the project team have shown that a cyanobacterial bloom forms in UKL during the warm summer months. Therefore, the initial suspended particulate matter survey was conducted on May 6, 2015-a time period deemed suitably representative of pre-bloom conditions. The majority of the algae present in UKL at this time were diatoms and brown algae. Environmental variables and organic aggregate population properties are summarized in table 20 . The ML site, with a local water depth of $4.5 \mathrm{~m}$, was the most turbid region in May 2015, with a SPMC of $140 \mathrm{mg} \mathrm{L}^{-1}$ at the $d p \_90$ sampling positions. Although technically the term "turbidity" is an optical property, its use survives in scientific/engineering/sediment transport literature as a relative comparative/descriptive term. The term turbidity maximum zone; any gravimetric type data are referred to as suspended particulate matter concentration (SPMC) in this section of the report. An abundance of organic aggregates (364) were observed in the sample 0515_S03 population at the ML site in the near-bed region. The scatterplot (fig. 2b) illustrates spherical-equivalent dry-mass-weighted organic-aggregate size plotted against settling velocity for the sample. The diagonal lines on the scatterplot represent contours of constant organic-floc effective (that is, immersed) density (units $=\mathrm{kg} \mathrm{m}^{-3}$; as a reference guide, a quartz mineral grain would have a $\rho_{\mathrm{e}}$ of about $1,600 \mathrm{~kg} \mathrm{~m}^{-3}$ ). These ambient conditions produced large, fast-settling organic aggregates, as demonstrated by the May 2015 survey peaks in both the mean organic aggregate size $(122 \mu \mathrm{m})$ and settling velocity $\left(3.28 \mathrm{mg} \mathrm{s}^{-1}\right)$. The macrofloc-sized organic aggregates were 85 percent porous and exhibited an average effective density ( $\rho_{\mathrm{e} \_}$macro) of 188 $\mathrm{kg} \mathrm{m}^{-3}$, whereas the microfloc-sized organic aggregates exhibited an average effective density ( $\rho_{\mathrm{e} \_ \text {micro }}$ ) of $628 \mathrm{~kg} \mathrm{~m}^{-3}$. However, these macrofloc-sized organic aggregates (73 in number) only represented under one-third of both the ambient SPMC and total mass settling fluxes (MSF, $464 \mathrm{mg} \mathrm{m}^{-2}$ $\mathrm{s}^{-1}$ ), and the organic macroflocs and smaller microfloc-sized organic aggregates each collectively demonstrated similar settling velocities $\left(\sim 3.3 \mathrm{~mm} \mathrm{~s}^{-1}\right)$.

At the shallower (water depth $=2.2 \mathrm{~m}$ ) LS01 site of UKL, the near-bed turbidity was significantly lower (SPMC $=11 \mathrm{mg} \mathrm{L}^{-1}$ ) than ML. Here, the low ambient particle abundance was seen to reduce the potential for constructive floc interparticle collisions, and this was reflected in the sample 0515_S06 flocs (fig. $2 \mathrm{~d}$ ) by both a much smaller $\mathrm{D}_{\text {mean }}$ of $79 \mu \mathrm{m}$ and a slower $\mathrm{Ws}_{\text {mean }}$ of $0.9 \mathrm{~mm} \mathrm{~s}^{-1}$ (table 20). This was a zone dominated by microfloc-sized organic aggregates, where 42 of the 44 flocs were organic microflocs, and this also translated through to the smaller microfloc-sized organic aggregates comprising 86 percent of the aggregate mass and settling flux.

Higher in the LS01water column, the 0515_S04 near-surface $\left(d p_{-} 10\right)$ floc sample (fig. $\left.2 \mathrm{c}\right)$ was composed solely of microfloc-sized organic aggregates, and the average Ws was $0.57 \mathrm{~mm} \mathrm{~s}^{-1}$, half the mean fall rate of the organic flocs in closer proximity to the bed. No organic macrofloc-sized organic aggregates were present.

The mass settling fluxes varied over a number of orders of magnitude between the sites and through the water column during the May 2015 sampling period. The MSF at the LS01 surface was 3 $\mathrm{mg} \mathrm{m}^{-2} \mathrm{~s}^{-1}\left(\mathrm{SPMC}=4.5 \mathrm{mg} \mathrm{L}^{-1}\right)$; this compared to a fourfold increase at the LS01 bed (MSF $=11.5 \mathrm{mg}$ $\left.\mathrm{m}^{-2} \mathrm{~s}^{-1}\right)$. Furthermore, the MSF at the ML near bed was 40 and 150 times higher than the southern region littoral habitat near-bed and surface organic flocs, respectively. 

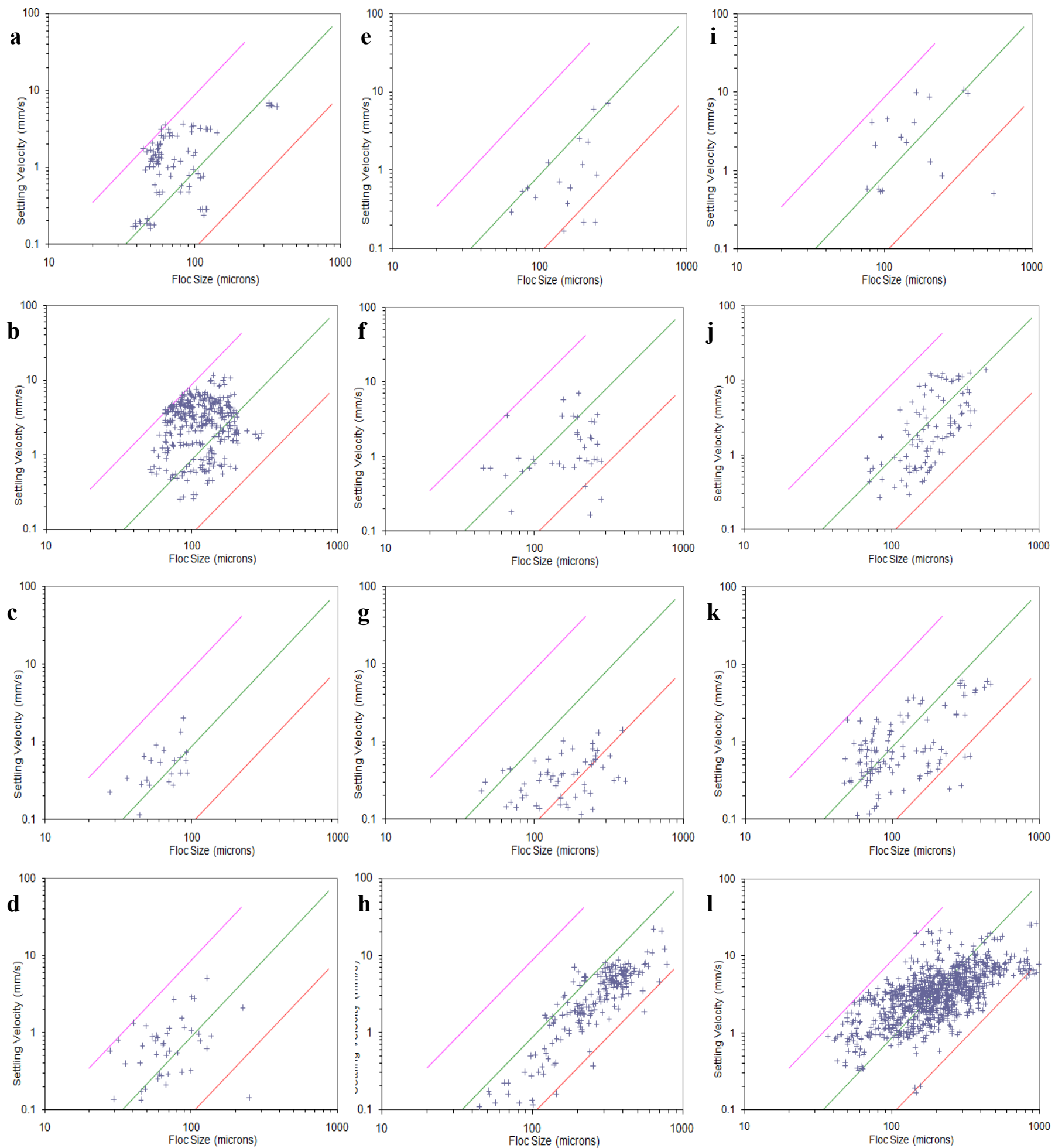

Figure 2 caption is on page 33 . 
Figure 2. Upper Klamath Lake organic aggregate (floc) size versus settling velocity population scatterplots. May 6, 2015: (a) 0515_S01 (ML dp_10), (b) 0515_S03 (ML dp_90), (c) 0515_S04 (LS01 dp_10), (d) 0515_S06 (LS01 dp_90). July 30, 2015: (e) 0715_S01 (ML dp_10), (f) 0715_S03 (ML dp_90), (g) 0715_S04 (LS01 dp_10), (h) 0715_S06 (LS01 dp_90). October 6, 2015: (i) 1015_S01 (ML dp_10), (j) 1015_S03 (ML dp_90), (k) 1015_S04 (LS01 dp_10), and (I) 1015_S06 (LS01 dp_90). The diagonal lines on the Ws versus D scatterplots represent contours of constant Stokes equivalent effective density: pink $=1,600 \mathrm{~kg} \mathrm{~m}^{-3}$, green $=160 \mathrm{~kg} \mathrm{~m}^{-3}$, and red $=16 \mathrm{~kg}$ $\mathrm{m}^{-3}$. $\mathrm{mm} / \mathrm{s}$, millimeters per second; microns, micrometers.

The summer (July 30,2015) sampling saw the cyanobacterial bloom well established in UKL (fig. 3). The lake was also $\sim 0.6 \mathrm{~m}$ shallower than in May 2015. The key organic aggregate parameters and environmental conditions for the July 30,2015, survey are summarized in table 21 . The ML site that was the most turbid during pre-bloom (May 2015) saw nearly an order of magnitude reduction in near bed SPMC, to $21 \mathrm{mg} \mathrm{L}^{-1}$ (sample 0715 S03, fig. 2f). The $\mathrm{D}_{\text {mean }}$ had risen by $56 \mu \mathrm{m}$ from May conditions to $178 \mu \mathrm{m}$. Also, the July ML flocs were only one-third the average effective density of the corresponding floc population observed near bed at ML in the pre-bloom May sampling (that is, $\rho_{\mathrm{e} \_}$mean of $170 \mathrm{~kg} \mathrm{~m}^{-3}$ compared to $540 \mathrm{~kg} \mathrm{~m}^{-3}$ ). It can be speculated that although the SPMC was lower at ML in July, the organic flocculation "collision efficiency" (Edzwald and O'Melia, 1975) could have risen owing to a higher level of EPS present in the lake, thus ensuring particles that came into contact would have a higher probability of sticking together and agglomerating. Although direct measurements of EPS were beyond the scope of this 2015 UKL study, one can see that in July 2015 (table 21), the macrofloc-sized organic aggregates (cyanobacterial colonies) outnumbered the smaller microfloc-sized fraction; they represented more than two-thirds of the organic aggregate mass for all July 2015 UKL organic aggregates (at both sites and through the water column) and over three-quarters of the MSF.

The near bed $\left(d p \_90\right)$ region at LS01 saw the peak summer SPMC of $316 \mathrm{mg} \mathrm{L}^{-1}$; this was nearly a thirtyfold rise in SPMC from May 2015 in the southern littoral habitat and over twice the turbidity encountered during the entire May 2015 organic flocculation survey. Of the 330 sample 0715_S06 organic aggregates (fig. $2 \mathrm{~h}$ ), 275 were of organic macrofloc-size classification. $\mathrm{D}_{\text {mean }}$ peaked at $30 \overline{5} \mu \mathrm{m}$, and the population average settling velocity was approaching $4 \mathrm{~mm} \mathrm{~s}^{-1}$. In fact, if we examine the D versus Ws scatterplot for sample 0715_S06, it shows that the highest order organic macrofloc-sized organic aggregates/cyanobacterial colonies had grown to almost $1 \mathrm{~mm}$ in diameter. The majority of the organic flocs were sandwiched between the lower density 160 and $16 \mathrm{~kg} \mathrm{~m}^{-3}$ density contours, edging close to the density of water (but remaining on the positive side). The delicate and fragile structure (most probably containing a large proportion of the resident low density organic-based algae) of these macrofloc-sized organic aggregates/large cyanobacterial colonies is indicated by a $\rho_{\mathrm{e} \_}$macro of $75 \mathrm{~kg} \mathrm{~m}^{-3}$ and an average porosity of 94 percent.

Some examples of organic aggregate images (from the LS01 site) during the summer cyanobacterial bloom are shown in figure 4c. Many of the macrofloc-sized organic aggregates/large cyanobacterial colonies present were approaching $1 \mathrm{~mm}$ in size, with an irregular clustered but fibrous appearance. It is apparent that although these are fast-settling macrofloc-sized organic aggregates/large cyanobacterial colonies, they are of low effective density and are highly porous; in fact, it is possible to see through many of these organic aggregates. These large summer macrofloc-sized organic aggregates/large cyanobacterial colonies are in contrast to the significantly smaller pre-bloom organic flocs observed during May 2015 at the ML site (fig. 4a). The May 2015 pre-bloom organic aggregates were more rounded in shape, such as flocs typically found in a low turbulent estuarial environment, and they appear to be less porous in composition (that is, it is not possible to see through them). 


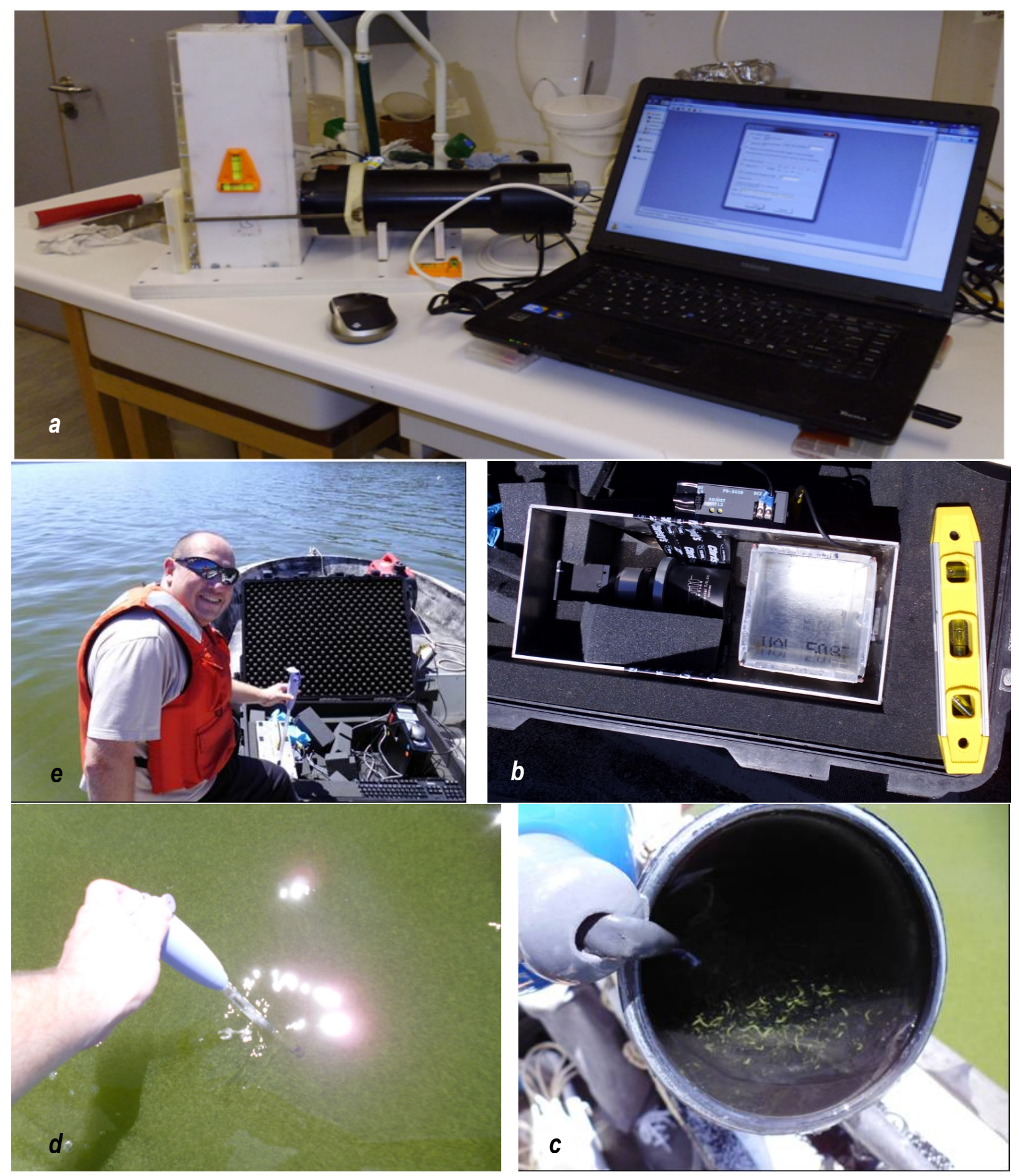

Figure 3. Photographs showing (a) a complete LabSFLOC-2 floc cam setup in a laboratory, with the settling column and camera on the left and computer with operating software and recording hard drive on the right. (b) Top view of U.S. Geological Survey (USGS) version of the LabSFLOC-2 floc cam setup in stainless steel housing in a Pelican waterproof case, with the camera and lens to the left and the settling column to the right. (c) July 2015, site LS01-collecting the near-surface floc sample directly from the water column using the modified pipette. Note green water color. (d) USGS Van Dorn sampler from same sampling. (e) Professor Manning transferring flocs. Photographs by Andrew Manning of Plymouth University, School of Marine Science and Engineering. 


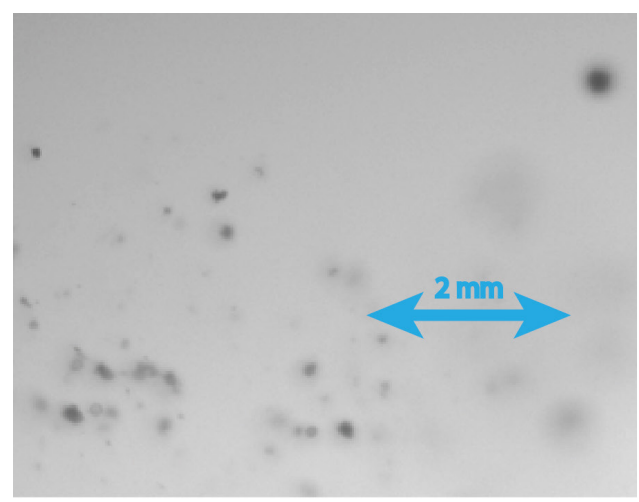

a. May 6th, 2015

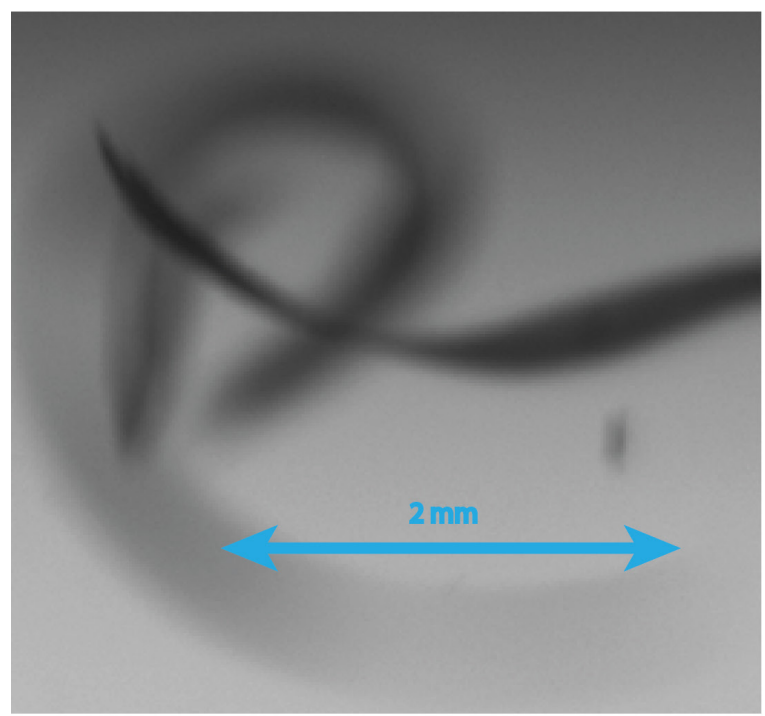

b. July 30th, 2015

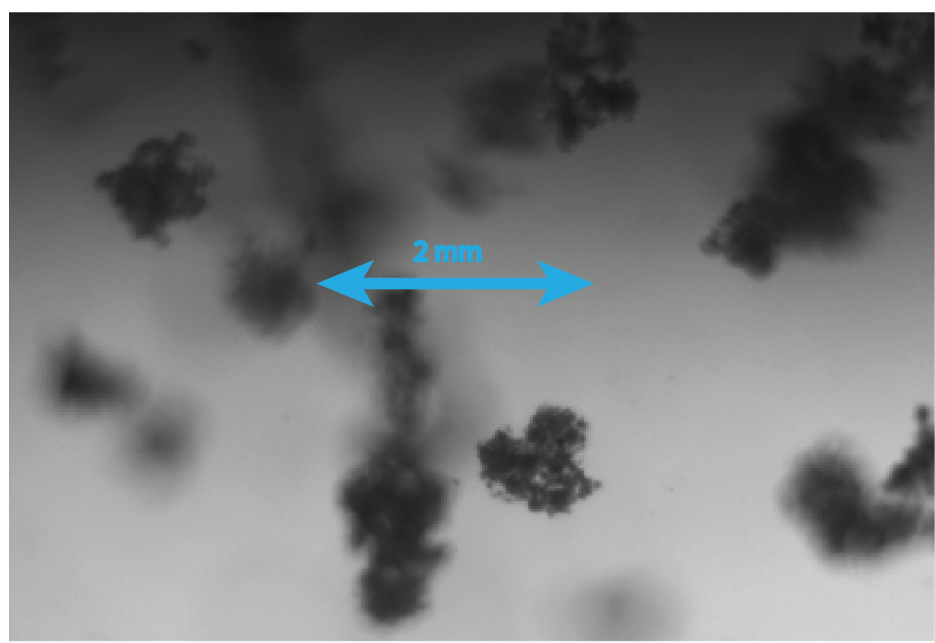

c. July 30th, 2015

Figure 4. Floc images from the LabSFLOC-2 floc cam collected during (a) the pre-bloom conditions, when Upper Klamath Lake is dominated by brown algae including diatoms (image shows other cyanobacterial colonies). Leaflike structures appear in the July sample (b), assumed to be individual Aphanizomenon flos-aquae (AFA) filaments. Organic aggregates during bloom conditions (c) include cyanobacterial colonies. Note: different scales for each image. 
Agglomeration dynamics may be linked (either directly or indirectly) to the depositional flux during the cyanobacterial bloom in UKL. For example, 94 percent of the organic floc mass for sample 0715_S06 were of macrofloc size, and given the elevated Ws for macrofloc of $4.5 \mathrm{~mm} \mathrm{~s}^{-1}$, macroflocsized organic aggregates/large cyanobacterial colonies comprised 98.8 percent of the total MSF of 1,580 $\mathrm{mg} \mathrm{m} \mathrm{m}^{-2} \mathrm{~s}^{-1}$. When comparing the bloom with pre-bloom settling fluxes, this maximum bloom settling flux (from LS01) was nearly four times greater than the peak MSF measured during pre-bloom (May 2015) at ML.

Even though the organic aggregate/cyanobacterial colonies in the near-bed region of the lake were seen to settle fairly swiftly, the presence of particles/organic aggregates throughout the water column, in particular near the water surface, is a clear indication that they are there in part owing to resuspension. Very little agitation is required to achieve this, especially for low density organic aggregate/cyanobacterial colonies. If this wasn't the case, then the lake should be clear of particles. Thus, wind-driven mixing and the resulting lake currents (even a low level contribution) is essential (see earlier comments in the "Overview" section).

In addition, many of the LabSFLOC-2 floc cam images observed during the July 2015 bloom depicted the presence of long, thin green, leafy strands (fig. 4b); these are thought to be individual AFA filaments. It is not known whether any of these filaments combine with the organic macroflocs/cyanobacterial colonies structures; however, Little (2000) found that when numerous phytoplankton threads are sticky with EPS, they can efficiently trap fine grains, thus providing a potential transport mechanism.

In terms of the data acquisition techniques, the LabSFLOC-2 floc cam method is primarily aimed at measuring settling properties of material that can be defined as sediment (whether it be organic or mineral in origin), that is, particles that are generally exchanged at the boundary between the bed and the water column. It is known that the movement of the AFA filaments is hugely complex; at times the cells are able to produce ballast to sink and gas vacuoles to float. For example, Nakamura and others (1993) specifically collapsed the gas vacuoles of AFA filaments to get settling and otherwise got flotation. However, with the floc cam measurements of the natural organic filaments and cyanbacterial colonies/organic aggregates, only settling was observed, and this would most likely be due to gravity, and therefore Stokes' law would be applicable. The organic macrofloc/large cyanobacterial colonies settled significantly quicker than the individual AFA filaments, but all were observed to be settling. Countering this, there would have to be observations of upward mobility. If it were present, the magnitude of the upward velocity relative to the settling velocity would need to be resolved, but no upward movement was observed in any of the floc cam video recordings.

The large macrofloc-sized organic aggregates/cyanobacterial colonies were of extremely low effective density, for example, figure $2 \mathrm{~h}$ shows that some had $\rho_{\mathrm{e}}$ of about $8-30 \mathrm{~kg} \mathrm{~m}^{-3}$. However, they still exhibited a density slightly greater than water. If the organic aggregates/cyanobacterial colonies and filaments had a density less than water, all the material would float and perhaps cover the entire water surface of the lake. If they were neutrally buoyant, they would not fall in a test column, and their settling speeds could not be measured. The collected water samples were run in the floc cam test immediately, and the particles were photographed as falling; therefore, we have to assume that such settling particles exist. For example, Mehta and others (2009) observed in Lake Apopka that the organic aggregates seem to contain biogenic silica (and not clays), and this can impart an additional downward velocity. To reiterate, as the organic aggregates/cyanobacterial colonies and AFA filaments were seen to fall in the floc cam test column, it was most likely due to gravity, and the use of Stokes' law assessment is deemed valid. 
The survey conducted in the autumn on October 6, 2015, was regarded as being representative of post-bloom conditions. However, there were still distinct traces of both cyanobacterial colonies (organic aggregates) and AFA filaments present in UKL, especially in the southern littoral habitat (LS01) region of Howard's Bay. The dry 2015 summer meant that the lake's water depth had decreased by a further 0.8-0.9 $\mathrm{m}$ in the autumn; this resulted in water depths of 3.1 and 0.7 $\mathrm{m}$ at ML and LS01, respectively.

The key floc parameters and environmental conditions for the October 6, 2015, survey are summarized in table 22, with the detailed D versus Ws scatterplots illustrated in figures $2 \mathrm{i}-1$. ML was only slightly more turbid than the summer 2015 conditions, with a $d p \_90$ SPMC of $62 \mathrm{mg} \mathrm{L}^{-1}$, and the sample 1015_S03 organic aggregates at this ML site in the near-bed region (fig. $2 \mathrm{j}$ ) demonstrated a mean settling velocity of $3.45 \mathrm{~mm} \mathrm{~s}^{-1}$, double the $\mathrm{Ws}_{\text {mean }}$ observed at the same location in July 2015 during the bloom.

At the very shallow water column present at LS01, the water sample SPMC of $828 \mathrm{mg} \mathrm{L}^{-1}$ indicated that the $d p \_90$ floc measurements (sample 1015_S06, fig. 21) were taken in the upper region of a benthic nepheloid layer (BNL), also known as a concentrated benthic suspension (CBS) layer, formed above the lake's bed. At an SPMC approaching $1 \mathrm{~g} \mathrm{~L}^{-1}$, the BNL would still tend to exhibit Newtonian rheological flow properties, interacting with the ambient flow and possessing a similar viscosity to water. The sample 1015_S06 comprised a total of 1,095 individual organic aggregates, of which 718 (or 65.5 percent) were of macrofloc size. Although some organic aggregates were $1 \mathrm{~mm}$ in size, the $\mathrm{D}_{\text {mean }}$ $(238 \mu \mathrm{m})$ was $67 \mu \mathrm{m}$ smaller than measured during the July bloom.

The $\mathrm{Ws}_{\text {Macro }}\left(4.74 \mathrm{~mm} \mathrm{~s}^{-1}\right)$ was similar to the macrofloc-sized organic aggregate settling observed in the July 2015 bloom, but the $\mathrm{Ws}_{\text {micro }}\left(2.31 \mathrm{~mm} \mathrm{~s}^{-1}\right.$ ) was $1.45 \mathrm{~mm} \mathrm{~s}^{-1}$ (or 168 percent) quicker. However, the October macrofloc-sized organic aggregates (predominantly cyanobacterial colonies) comprised 84 percent of the aggregate mass, a 10 percent decrease from July, and this resulted in the 1015_S06 $\mathrm{Ws}_{\text {mean }}\left(3.91 \mathrm{~mm} \mathrm{~s}^{-1}\right)$ being very similar to the July conditions. In terms of organic aggregate structure, the post-bloom organic aggregates within the BNL at site LS01 had a mean effective density and porosity of $220 \mathrm{~kg} \mathrm{~m}^{-3}$ and 82.5 percent, respectively. This made the October 2015 BNL organic aggregates generally more dense $\left(140 \mathrm{~kg} \mathrm{~m}^{-3}\right)$ and less porous $(-12$ percent $)$ than the preceding bloom organic aggregates at LS01 in the $d p \_90$ region.

The high SPMC experienced by sample 1015_S06 in the BNL produced a total MSF of 4,139 $\mathrm{mg} \mathrm{m}^{-2} \mathrm{~s}^{-1}$ (92.1 percent credited to the organic macrofloc-sized aggregate fraction); that was nearly three times the corresponding settling flux observed during July and 360 times greater than the prebloom conditions from May 2015 (98.8 percent and 14 percent credited to the macrofloc-sized fraction at LS01 from $d p \_90$ for those respective months).

Based on research conducted in other lakes that experience cyanobacterial blooms, such as Lake Apopka in central Florida (Mehta and others, 2009), these studies are in agreement with the presence of high SPMCs existing in close proximity to Upper Klamath Lake's bed (that is, SPMCs increase owing to gravity settling), and that would mean that part of the BNL in the lake may demonstrate characteristics of a non-Newtonian fluid mud.

A BNL, or the more turbid fluid mud (FM), is an entirely ephemeral state of mud. It is known to occur in large and shallow lakes where the bottom often contains clayey sediment (for example, Lake Okeechobee, Fla.). Where the suspended matter is mainly organic (for example, Lake Apopka, Fla.), the term "fluid mud" is still often used within scientific/engineering/sediment transport community literature even though there is little mud present. The main attributes of a BNL and the more turbid FM are that (1) it is a dense slurry defined by hindered settling, that is, settling of the slurry as a whole as opposed to individual flocs/aggregates. The rate of settling of the slurry is dependent on the rate at which water escapes the slurry upward. The settling of aggregates within FM becomes hindered, and 
their terminal velocities progressively slow with rising turbidity (Odd, 1988). When organic-rich sediments form such slurries at lake bottoms, they can be $10-30 \mathrm{~cm}$ in thickness.

The BNL or FM slurry (2) has viscoelastic properties defined by yield stress, which can be measured in a viscometer. Rheologically, FMs behave as a pseudoplastic; that is, they have high viscosity at low shear rates, but their viscosity reduces at high shear rates. Further increases in concentration can transform an FM's rheological properties into a Bingham plastic (Sills and Elder, 1986), and the FM then becomes a soft bed material. An understanding of FM/BNL distributions and their dynamics is critical, principally because of the well-established connection between the dynamics of organic aggregates and the resultant transport pathways of any contaminants present within that aquatic system (Thorne and Nickless, 1981; Duquesne and others, 2006). This could be an important additional topic for future research in UKL.

Collectively, all organic aggregate populations observed within UKL demonstrated a fairly wide range in Ws for a constant D (fig. 2) and, similarly, a varying span in D for a constant Ws. This indicates the influence of varying organic aggregate effective density and its effect on mass and MSF. This also demonstrates the highly significant seasonal effects that the AFA bloom (in particular, the formation of the large macrofloc-sized organic aggregates/cyanobacterial colonies) has on the organic aggregate depositional fluxes in UKL and highlights the importance of seasonal monitoring of these conditions in order to correctly parameterize the wide range in depositional characteristics and organic aggregate properties measured throughout UKL. Thus, it is extremely important to use an instrument (such as the INSSEV-LF) that is capable of measuring the variability of settling velocity and its relation to organic aggregate density and size.

\section{Methods}

Until 2013, benthic-flux studies had been limited spatially to a number of sites in the northern region of the lake and to 2-3 samplings per year (Kuwabara and others, 2012a). Virtually nothing was known about either the spatial or temporal variability in benthic solute sources for the entire lake. This limitation was addressed with a lakewide spatial study for 2013 (fig. 1) and a temporal study with weekly sampling for 2014.

During field work in the spring and summer of 2013, we collected samples from three lake regions of approximately equal projected area, using letters " $\mathrm{N}$," " $\mathrm{C}$," and " $\mathrm{S}$ " in site labels to designate northern, central, and southern regions, respectively. Two lake habitats were sampled: three littoral sites with labels beginning with the letter "L" and three open-lake sites with labels beginning with the letter "O" within each region. Three littoral and three open-lake sites were randomly located in each of the three regions. In addition, three sites within the western trench feature of the lake were located in the central region and labeled beginning with the letters "TR.” After a reconnaissance trip on May 1, 2013, to test new sampling equipment and protocols, all 21 sites were sampled on 3 dates that were approximately 3 weeks apart and that encompassed the development of the first AFA bloom. Sampling of the 21 sites occurred on May 23, June 13, and July 3, 2013, as the annual AFA bloom developed.

Analysis of the 2013 SRP benthic-flux measurements unexpectedly indicated no effect of location (lake region), habitat, or sampling period. Furthermore, the average lakewide flux values were consistent with earlier studies that had been confined to the northern region of the lake and adjacent wetlands (Kuwbara and others, 2009; Kuwabara and others, 2012a). The experimental design for the 2014 temporal study therefore focused on site ON01 within Ball Bay because it (1) had representative SRP fluxes in 2013, (2) had representative benthic invertebrate assemblages, (3) had good accessibility during periods of high winds within Ball Bay, and (4) allowed the study to focus the allocation of available resources to optimize temporal resolution of benthic solute source measurements. Results of 
the 27-week study in 2014 were partitioned into three 9-week periods (referred to herein as pre-bloom, bloom, and post-bloom periods), based on water-column chlorophyll concentrations: (1) April 15 through June 10, (2) June 17 through August 13, and (3) August 20 through October 16, 2014, respectively. Shaded rows in tables 10 through 15 distinguish results from the bloom period relative to the unshaded pre-bloom and post-bloom results.

Nonmetallic pore-water profilers, designed for nutrient and trace-metal sampling (U.S. Patent 8,051,727 B1 issued November 8, 2011; Kuwabara and others, 2009), were deployed in triplicate at each sampling site. In addition to water just above the sediment-water interface (approximately $1 \mathrm{~cm}$ ), samplers were capable of collecting $0.2-\mu \mathrm{m}$-filtered interstitial water from five depths within the top 10 centimeters of the sediment. That is, a total of six independent sampling circuits per profiler could be used to characterize dissolved-solute vertical gradients. In 2013, each profiler was set up to provide two samples from the above the sediment water interface, two from $1 \mathrm{~cm}$ below that interface, and two from $2 \mathrm{~cm}$ below the interface. The design allowed for two measurements of solute benthic flux per profiler. By comparison, in the 2014 temporal study, six profilers were deployed where each profiler sampled from just above the sediment-water interface and 1, 2, 3.3, 5.5, and $10 \mathrm{~cm}$ below the interface.

Each of the six sampling circuits collected filtered $(0.2 \mu \mathrm{m})$ water into $50-\mathrm{mL}$ acid-washed, allplastic syringes. After being lowered onto the sediment, the device was tripped mechanically to begin sample collection and then retrieved approximately 24 hours later. In contrast to passive sampling by dialysis, samples are slowly drawn through a series of filters into a $60-\mathrm{mL}$ all-plastic, valved syringe. Dye experiments indicated that this extended sampling period with low flow rates avoided shortcircuiting of samples between depths and along device surfaces. After retrieval, the sample syringes were closed with a valve, double-bagged in argon, and refrigerated in darkness for sample processing, splitting, and later chemical analyses.

Flux calculations, based on Fick's law, assumed that the benthic flux is diffusion controlled with solute-specific diffusion coefficients (Li and Gregory, 1974; Applin, 1987; Lead and others, 2000; Rebreanu and others, 2008). To provide a conservative estimate for DOC flux, a diffusion coefficient of $2 \times 10^{-6} \mathrm{~cm}^{2} \mathrm{~s}^{-1}$ was used, the lower end of the range from 2 to $3 \times 10^{-6} \mathrm{~cm}^{2} \mathrm{~s}^{-1}$ reported by Lead and others (2000) for DOC diffusivity. Benthic fluxes $\left(J_{i}\right.$ in $\left.\mathrm{mg} \mathrm{m}^{-2} \mathrm{~d}^{-1}\right)$ were calculated using the equation

$$
J_{i}=D_{i, T}(\varphi)(d C / d z)
$$

where $D_{i, T} \quad$ diffusion coefficient of solute $i$ at temperature $T$ in $\mathrm{cm}^{2} \mathrm{~s}^{-1}$,

$\varphi \quad$ sediment porosity in dimensionless units, and

$d C_{i} / d z \quad$ concentration gradient for solute $i$ in the vertical (or $z$ ) direction in $\mathrm{mg} \mathrm{cm}^{-4}$, with calculated flux values converted to meter and day units. Pore-water and overlying water concentrations from each profiler were fit to an exponential gradient model as described by Klump and Martens (1981). Where nondetectable concentrations were observed, summary statistics for concentrations and gradients were calculated using half of the detection limit for that sample (in the case of nitrate, $0.005 \mathrm{mg}-\mathrm{N} \mathrm{L}^{-1}$ ), after agreement with Kaplan-Meier analysis (Frome and Watkins, 2004). With the exception of silicate (as $\mathrm{SiO}_{2}$ ), fluxes and concentrations are presented in terms of elements, not molecules. For example, SRP flux is provided in terms of $\mathrm{P}$, not phosphate.

Diffusive fluxes can be influenced by bioturbation, bioirrigation, metabolic cycling, wind resuspension, and potential groundwater inflows (Reddy and DeLaune, 2008; Kuwabara and others, 2009). Hence, the calculated benthic flux of dissolved solutes based on pore-water profiles is a conservative estimate that provides lower bounds indicating the potential importance of such internalsolute sources. Tabulated results include standard deviations about mean values for the number of replicates specified in the tables (tables $3,7,12$, and 14). 
At each site, data loggers provided water-column profiles of ancillary parameters $(\mathrm{pH}$, salinity, temperature, dissolved oxygen, and oxidation-reduction potential), monitored at 15 -second periods at the time profilers were retrieved. Sampling methods have been previously described (Kuwabara and others, 2003; Kuwabara and others, 2009), but details are provided below. At each site, the following samples were collected, unless otherwise noted.

\section{Biological Parameters}

\section{Benthic Chlorophyll a}

Upon completion of water-column sampling at a site, surficial sediment (that is, the top centimeter of bed material) was collected for benthic chlorophyll $a$ analysis from a fresh Ekman grab and stored refrigerated in a plastic Petri dish within a sealed plastic bag. Each dish was subsampled in triplicate for benthic chlorophyll $a$. The surficial sediment for each replicate $\left(0.785 \mathrm{~cm}^{2}\right)$ was collected on a glass-fiber filter and buffered with $1 \mathrm{~mL}$ of a supersaturated magnesium carbonate suspension $(10 \mathrm{~g}$ $\mathrm{L}^{-1}$ ). Water was removed from the buffered samples by vacuum at less than 5 pounds per square inch (psi) to avoid cell lysis. Samples were then frozen on dry ice and later at $-80{ }^{\circ} \mathrm{C}$ and held in darkness for preservation until analyzed spectrophotometrically (before 2007-2010) or by fluorometer (2013 samples), which occurred within 3 months (Thompson and others, 1981; Franson, 1985).

\section{Benthic Invertebrate Sampling}

Benthic invertebrates were collected using a tall Ekman grab that was modified to limit its penetration into the soft UKL substrate to approximately $10 \mathrm{~cm}$. The volume of the grab was approximately $15.2 \mathrm{~cm} \times 15.2 \mathrm{~cm} \times 10 \mathrm{~cm}$ deep. All grabs were individually sieved in the field using a $500-\mu \mathrm{m}$ mesh sieve to remove excess fine sediment. The material retained on the sieve was preserved in 10 percent buffered formalin. Each grab was transferred to 70 percent ethanol within a week of collecting. Each benthic invertebrate sample is the mean of three Ekman grabs in 2013 and the mean of five Ekman grabs in 2014.

\section{Benthic Invertebrate Sample Processing}

Individual Ekman grabs were sorted in the laboratory using a dissecting microscope at $7 \times-10 \times$ magnification. Samples were stained with Rose Bengal to facilitate sorting and (or) randomly subsampled when necessary (less than 1 percent of the grabs). When subsampling was necessary, the procedures in Moulton and others (2002) were followed. Representative Chironomidae and Oligochaeta were initially identified from slide-mounted specimens, using standard keys. Based on this reference collection, all invertebrates were identified to the lowest practicable taxonomic level using the dissecting microscope. When necessary, operational taxonomic units (OTUs) were developed. Andersen and others (2013), Kathman and Brinkhurst (1998), and Davies and Govedich (2001) were used to identify Chironomidae, Oligochaeta and Hirudinea, respectively. Over all samples, 33 percent of taxa were identified to species (or equivalent OTU), 41 percent to genus, and 26 percent to greater than genus (for example, tribe, subfamily, family). Nonbenthic microcrustaceans were not sorted or identified because they represented contamination from sieving the samples in the field. Polychaetes (Manayunkia speciosa) and nematodes were not sorted because they were poorly sampled using 500- $\mu \mathrm{m}$ mesh. 


\section{Benthic Invertebrate Nutrient Release Experiments}

Benthic invertebrates used for nutrient release (efflux) experiments were collected using the modified Ekman grab. Collected grabs were placed in an ice chest lined with doubled polyethylene bags. Lake water was added, and a battery powered pump provided aeration. Samples were cooled to maintain the approximate temperature at which benthic invertebrates were collected during transport back to the laboratory. Ice was kept in a bag separate from the invertebrates.

Samples were sieved in the laboratory using lake water. Retained invertebrates were placed in Whatman (GF/F) filtered lake water and then artificial lake water (table 18) to remove any attached debris. Either individual organisms or multiple organisms of the same taxon were placed in a $15-\mathrm{mL}$ acid-washed Teflon container along with $5 \mathrm{~mL}$ of artificial lake water. The container was then placed in an incubator set at the temperature at which invertebrates were collected. Release rates were typically measured over a 4-hour period.

Once the test period ended, the invertebrate(s) was removed and placed in 70-percent ethyl alcohol for later taxonomic confirmation. The remaining test solution was filtered into a $6.5-\mathrm{mL}$ Vacuette vial using a $0.22-\mu \mathrm{m}$ polycarbonate syringe filter. Procedural blanks represented $>20$ percent of all samples. Typically, a series of tests was performed on the same day. The number of test vials per series ranged from approximately 50 to just over 100. Nutrient analyses are described below.

\section{Chemical Parameters}

\section{Dissolved Nutrients}

Nutrient samples were collected from profiler syringes or grab samples $(\sim 0.5-\mathrm{m}$ depth), then filtered $(0.2-\mu \mathrm{m}$ polycarbonate membranes) and immediately refrigerated in darkness without acidification. Concentrations were determined for dissolved (0.2- $\mu \mathrm{m}$ filtered) nitrate-nitrite (EPA method 353.1), ammonia (EPA method 350.1), orthophosphate (SRP; EPA method 365.2), and silica (EPA method 370.1) by batch automated spectrophotometry (Aquakem 250, Thermo Scientific). As mentioned above, concentration units for dissolved nutrients are in terms of the element rather than the associated molecule, with the exception of silica as $\mathrm{SiO}_{2}$. For example, the concentration unit specified herein for dissolved ammonia is milligrams of nitrogen per liter $\left(\mathrm{mg}-\mathrm{N} \mathrm{L}^{-1}\right)$, as opposed to an ammonia species.

Certified standards for all nutrients were purchased from Microgenics Corporation (Fremont, California), and a new calibration curve is established for each analyte on each analytical day. For further quality assurance and quality control (QA/QC), certified standards and blanks are also analyzed every 10-20 samples.

Method detection limits (MDL) for each analyte were determined and established for all samples reported. For nitrate and nitrite, the MDL is $0.01 \mathrm{mg}-\mathrm{N} \mathrm{L}{ }^{-1}$. For ammonia, the MDL is $0.007 \mathrm{mg}^{-\mathrm{N} \mathrm{L}^{-1}}$. For orthophosphate (SRP), the MDL is $0.002 \mathrm{mg}-\mathrm{P} \mathrm{L}^{-1}$. For silica, the MDL is $0.1 \mathrm{mg}-\mathrm{SiO}_{2} \mathrm{~L}^{-1}$.

\section{Dissolved Organic Carbon (DOC)}

Dissolved organic carbon samples were collected in duplicate in baked 60-mL glass bottles with acid-washed fluoroethylene-polymer caps and filtered $(0.7-\mu \mathrm{m}$ baked glass-fiber filter) for analysis by high-temperature catalytic combustion (Vandenbruwane and others, 2007).

Potassium phthalate was used as the standard. Low-DOC water (blanks less than $40 \mu \mathrm{g}-\mathrm{C} \mathrm{L}^{-1}$ ) was generated from a double-deionization unit with additional ultraviolet treatment (Milli-Q Gradient, Millipore Corporation). A new calibration curve is established on each analytical day. For further 
QA/QC, certified standards and blanks are also analyzed every 10-20 samples. For DOC, the MDL is $0.1 \mathrm{mg}-\mathrm{C} \mathrm{L}^{-1}$.

\section{Dissolved Trace Elements}

Water-column samples were collected in duplicate in 250-mL acid-washed high-density polyethylene bottles, filtered $(0.2-\mu \mathrm{m}$ polycarbonate membrane) using clean technique (Fitzwater and others, 1982), and acidified ( $\mathrm{pH}$ 2). Pore-water samples were filtered in-line and acidified before analysis by the above water-column methods. All solutions were analyzed for trace metals by inductively coupled plasma mass spectrometry (ICP-MS, EPA method 200.8) (Topping and Kuwabara, 1999; Topping and Kuwabara, 2003). As with dissolved macronutrients, concentration units for dissolved trace elements are in terms of the element rather than the associated molecule. For example, the concentration unit specified herein for dissolved vanadium is $\mu \mathrm{g}-\mathrm{V} \mathrm{L}^{-1}$, rather than the vanadate ligand.

Certified standards for all trace metals were purchased from High Purity Standards (Charleston, South Carolina), and a new calibration curve is established for each metal on each analytical day. For further QA/QC, certified standards and blanks are also analyzed every 10-20 samples.

Method detection limits (MDL) for each metal were determined and established for all samples reported. For nitrate and nitrite, the MDL is $0.01 \mathrm{mg}-\mathrm{N} \mathrm{L}{ }^{-1}$. For ammonia, the MDL is $0.007 \mathrm{mg}^{-\mathrm{N} \mathrm{L}^{-1}}$. For orthophosphate (SRP), the MDL is $0.002 \mathrm{mg}-\mathrm{P} \mathrm{L}^{-1}$. For silica, the MDL is $0.1 \mathrm{mg}_{-} \mathrm{SiO}_{2} \mathrm{~L}^{-1}$.

\section{Physical Parameters}

\section{Heat Transfer Modeling}

As a comparative approach to estimating hydrologic transport across the sediment-water interface in the lake, a set of three temperature loggers (fig. 5) was deployed at 6 of the 19 piezometer sites. These sites, from north to south, included LN01, ON01, OC01, SPR, OS02, and LS01. Temperature loggers were installed onto 1.25 -inch, schedule 80 PVC pipe to measure a time series of water temperature at (1) the sediment-water interface, (2) $30 \mathrm{~cm}$ below that interface, and (3) $150 \mathrm{~cm}$ below that interface. Depth of the temperature sensors was regulated by a PVC cross member that contacted the piezometer plate and served as a vertical stop. The unconsolidated nature of the lakebed sediments at these six sites allowed the manual deployment of the thermistor pipes without need of a slide hammer. Once deployed, the thermistor pipes were tied with twine to the adjacent piezometer pipe. Temperature loggers recorded water temperature at 5-minute intervals. Within 2 months of deployment, the temperature-sensor pipes at sites OC01 and OS02 were lost owing to pipe breakage or possibly vandalism. Therefore, heat-transfer modeling, using program 1DTempPro V2 (Koch and others, 2015), was done for the remaining four sites LN01, ON01, SPR, and LS01 (table 19). The temperature data were segmented into three 2-week periods. The first was as the bloom developed between July 1 and 14 , 2015. The second was within the cyanobacterial blooms between August 5 and 19, 2015, and the final post-bloom period was between September 10 and 24, 2015. The 1DTempPro program uses the temperature time series and estimates for sediment characteristics (that is, porosity, thermal conductivity, and heat capacity) to model an output of groundwater discharge. The modeled discharge, along with the overlying water and 1-cm depth SRP concentrations for the nearest sampling date in 2013, were used to estimate the advective flux of SRP. 


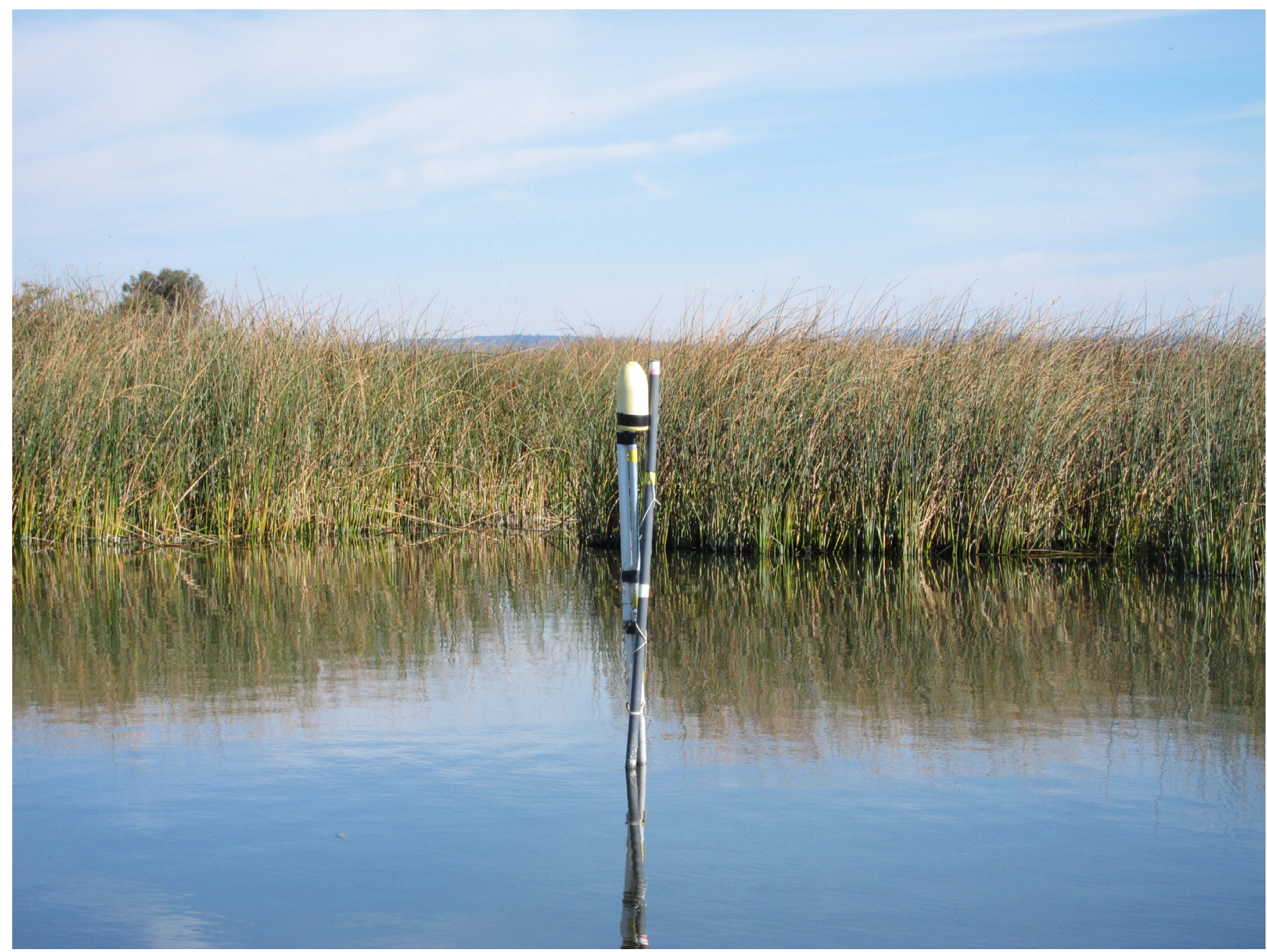

Figure 5. Photograph showing a piezometer and thermistor string deployed at one of the northern littoral-zone sites. Photograph by Francis Parchaso of the U.S. Geological Survey.

\section{Vertical Hydraulic Gradient.}

Previous estimates of heat transfer near the sediment-water interface provided preliminary data suggesting the potential importance of physical (hydrologic) transport of solutes between the lakebed and overlying water column (Kuwabara and others, 2009). To examine this process further, piezometers were deployed at all 18 open-lake and littoral-zone sites studied in the 2013 spatial-variability experiment (fig. 5). A piezometer was deployed at an additional seep/spring site (SPR, fig. 1) in proximity to: (1) visible groundwater inputs at the lakeshore, and (2) fish-habitat spawning experiments. Piezometers were deployed to a depth of $150 \mathrm{~cm}$ below the lakebed and threaded to 0.75 -inch galvanized pipe. A transition from 0.75 -inch to 1 -inch pipe was used to locate a vertical stop for a pressure transducer/data logger placed to record the head $150 \mathrm{~cm}$ below the lakebed. The piezometer depth was set by a $40-\mathrm{cm}$ square PVC plate (1-cm thick) that rested on the lakebed, with a central hole that was slipped onto and then clamped onto the piezometer pipe. Stainless steel band clamps secured a 2-inch schedule $40 \mathrm{PVC}$ stilling well to the piezometer pipe. A pipe cap was perforated at the bottom of the stilling well to serve as a vertical stop for a pressure transducer placed to record lake stage. A 381$\mu \mathrm{m}$ copper mesh was epoxied to the inner cap surface to retard biofouling of the outer transducer. For 
each piezometer deployment site, the time series of water-column heights downloaded from the transducers in the piezometer and the stilling well at 5-minute intervals were used to calculate the dimensionless vertical hydraulic gradient (VHG, the difference between the inner and outer transducer heights divided by the piezometer deployment depth, $150 \mathrm{~cm}$ ). The product of VHG and the hydraulic conductivity $(\mathrm{K})$ provides an estimate of vertical discharge. The installations did not perform as intended in that the positions of the pressure transducers were not stable and appeared to shift in response to external influences (such as wave action). Moreover, when transducers were removed and replaced during site visits, they did not always return to their original positions. Unfortunately, the uncertainty in the data owing to this problem is on the same order as the head gradient. Consequently, the magnitude and direction of the head gradient cannot be reliably determined from the data. Because of this, advective flux estimates presented at this point rely solely on the temperature data (temperature loggers were not affected by this problem). This effort did demonstrate the feasibility of measuring head gradients between the lake and underlying sediment. The problems experienced with the 2015 data collection can be avoided in future studies with modest modifications to the piezometer design and periodic field verification of precise transducer positions.

\section{Flocculation and Settling Methodology}

For this work, the term "floc" refers to suspended particles that may aggregate or disaggregate to change in size and settling velocity. Three surveys (conducted on May 6, 2015; July 30, 2015; and October 6, 2015) collected floc population samples through the water column from two pre-selected sites in UKL where flocculation data was required. Site LS01 (Littoral-Zone South) was close to the shoreline in Howard's Bay, and the site ML (Middle Lake) (fig. 1) was in the vicinity of the middle of the lake. The sites were selected to correspond with locations where USGS and Reclamation long-term instrumentation were deployed and regular observations made throughout 2015 and previous years.

The floc data was collected at each station in a quasi-Eulerian manner. The research vessel was brought close to stationary at each sampling station and remained on station, anchored from the bow, during floc data measurements.

Six floc populations (three from each site) were sampled within UKL during each of the three 2015 survey using the INSSEV-LF: In-Situ Settling Velocity Instrument. In order to obtain a representative picture of how floc characteristics varied through depth at each site in the lake, water samples (from which flocs were later extracted) were collected nominally at points 10 percent $\left(d p_{-} 10\right.$, near-surface), 70 percent ( $d p \_70$, near-bed), and 90 percent ( $d p \_90$, close-to-bed) of the local total water column depth. Only results from the $d p_{-} 10$ and $d p_{-} 90$ sampling points are included in this summary report. Vessel position and logger time synchronization were established from a portable Global Positioning System (GPS) unit. Pacific local time was used to time reference all the survey floc data.

Manning and Schoellhamer (2013) describe the typical INSSEV-LF measurement methods in detail, and they are summarized here. The LF (LabSFLOC) version of INSSEV is a hybrid system that combines two key components: (1) the low intrusive LabSFLOC system, a high resolution video-based device to measure the individual floc properties; (2) an in-situ estuarine floc sampler. The LabSFLOCLaboratory Spectral Flocculation Characteristics - instrument (Manning, 2006) enables individual floc sizes and settling velocities to be measured simultaneously and was set up on a 22-foot ( $\sim 6.8 \mathrm{~m})$ long, shallow draft vessel. The LabSFLOC-2 (version 2; A.J. Manning, written commun., 2016) digital camera resolution can practically view particles/flocs down to $5 \mu \mathrm{m}$ in size (fig. 3) and as large as 8 $\mathrm{mm}$. Settling velocities generally ranging from 0.01 to $45 \mathrm{~mm} \mathrm{~s}^{-1}$ can be measured by LabSFLOC-2, and it can operate within suspended particulate matter concentrations (SPMCs) of just a few mg L ${ }^{-1}$, with a practical upper operating limit of $\sim 8.5 \mathrm{~g} \mathrm{~L}^{-1}$. 
A 2.2-L Van Dorn horizontal sampling tube (fig. 3) with a 10-kg weight suspended from the underside of the tube was used to collect a water sample nominally at each of the three sampling depths. A small subsample containing a floc population was carefully extracted from the horizontal Van Dorn using a 0.4-m-long modified pipette (nominal internal diameter $=6 \mathrm{~mm}$ ). This sample was immediately transferred to the LabSFLOC settling chamber, whereby the flocs passed from the vertically held pipette to the chamber and settled solely under gravity (fig. 3). Settling velocity and diameter of individual flocs were determined from the digital video AVI (Audio Video Interleave) recordings using the H.R.

Wallingford Ltd DigiFloc software, version 1.0 (T. Benson and A.J. Manning, written commun., 2016). Floc effective density $\left(\rho_{\mathrm{e}}\right)$, porosity, and floc mass were calculated using specially derived algorithms (Fennessy and others, 1997) adapted by Manning (2004).

The floc collection and subsampling protocols are both proven floc sampling techniques (A.J. Manning, written commun., 2016; Manning and others, 2010a, b; Mehta and others, 2009), which permit minimal floc interference and flocs that are representative of the ambient population-especially in terms of floc size and settling velocity distributions. Extensive testing of this sampling protocol revealed that this technique created minimal floc disruption during acquisition (see Gratiot and Manning, 2004). The floc sampling techniques also provide control volumes, which permit settling flux estimations (that is, the product of the floc mass and settling velocity).

In addition to determining sample mean floc properties, a diameter of $160 \mu \mathrm{m}$ is a convenient demarcation between smaller microflocs and larger macroflocs (Manning, 2001); these are typically used for numerical sediment transport modeling parameterization (for example, Soulsby and others, 2013; Winterwerp and others, 2006).

\section{References Cited}

Andersen, T., Cranston, P.S., and Epler, J.H., eds., 2013, Chironomidae of the Holarctic Region; Keys and diagnoses, Part 1-Larvae: Insect Systematics and Evolution Supplements, v. 66, p. 1-571.

Anderson, M.P., 2005, Heat as a ground water tracer: Ground Water, v. 43, p. 951- 961.

Applin, K.R., 1987, The diffusion of dissolved silica in dilute aqueous solution: Geochimica et Cosmochimica Acta, v. 51, p. 2147-2151.

Arillo, A., Margiocco, C., Melodia, R., Mensi, P., and Schenone, G., 1981, Ammonia toxicity mechanism in fish; studies on rainbow trout (Salmo gairdneri Rich.): Ecotoxicology and Environmental Safety, v. 4, p. 316-328.

Atkins, J.P., 2016, Water quality standards_-beneficial uses, policies and criteria for Oregon: Oregon Department of Environmental Quality, Table 40, accessed at http://arcweb.sos.state.or.us/pages/rules/oars_300/oar_340/340_041.html.

Baugh, J.V., and Manning, A.J., 2007, An assessment of a new settling velocity parameterisation for cohesive sediment transport modelling: Continental Shelf Research, v. 27, p. 1835-1855, doi:10.1016/j.csr.2007.03.003.

Beversdorf1, L.J., Miller, T.R., and McMahon, K.D., 2013, The role of nitrogen fixation in cyanobacterial bloom toxicity in a temperate, eutrophic lake: PLoS ONE, v. 8, 11 p., e56103. doi:10.1371/journal.pone.0056103.

Boudreau, B.P., and Jorgensen, B.B., 2001, The benthic boundary layer, transport processes and biogeochemistry: New York, Oxford University Press, 404 p.

Bouwer, H., and Rice, R.C., 1976, A slug test method for determining hydraulic conductivity of unconfined aquifers with completely or partially penetrating wells: Water Resources Research, v. 12, no. 3 , p. $423-428$. 
Bredehoeft, J.D., and Papadopulos, I.S., 1965, Rates of vertical ground water movement estimated from Earth's thermal profile: Water Resources Research, v. 1, p. 325-328, doi:10.1029/WR001i002p00325.

Brooks, B.W., Lazorchak, J.M., Howard, M.D.A., Johnson, M.V., Morton, S.L., Perkins, D.A.K., Reavie, E.D., Scott, G.I., Smith, S.A., and Steevens, J.A., 2016, Are harmful algal blooms becoming the greatest inland water quality threat to public health and aquatic ecosystems?: Environmental Toxicology and Chemistry, v. 35, p. 7-13.

Canadian Council of Ministers of the Environment, 2010, Canadian water quality guidelines for the protection of aquatic life: Environment Canada, 8 p., accessed at ceqg-rcqe.ccme.ca/download/en/141. Constantz, J., 2008, Heat as a tracer to determine streambed water exchanges: Water Resources Research, v. 44, W00D10, doi:10.1029/2008WR006996.

Constantz, J., Tyler, S.W., and Kwicklis, E., 2003, Temperature-profile methods for estimating percolations rates in arid environments: Vadose Zone Journal, v. 2, p. 12-24.

de Brouwer, J.F.C., Wolfstein, K., Ruddy, G.K., 2005, Biogenic stabilization of intertidal sediments; The importance of extracellular polymeric substances produced by benthic diatoms: Microbial Ecology, v. 49, p. 501-512.

Davies, R.W., and Govedich, F.R., 2001, Annelida-Euhirudinea and Acanthobdellidae, in Thorp, J.H., and Covich, A.P., eds., Ecology and classification of North American freshwater invertebrates: San Diego, Academic Press, p. 465-504.

Davis, J., Jewett, S.G., Jr., and Mote, D.C., 1938, Klamath midge investigations [unpublished report]: Corvalis, Oregon, Agricultural Experiment Station, Department of Entomology.

Debarshi, R., Gaur, P., Verma, N., Pathireddy, M., and Singh, K.P., 2013, Bioremediation of arsenic (III) from water using baker yeast Sacchromyces cerevisiae: International Journal of Environmental Bioremediation \& Biodegradation, v. 1, p 14-19, doi:10.12691/ijebb-1-1-3.

Devine, J.A., and Vanni, M.J., 2002, Spatial and seasonal variation in nutrient excretion by benthic invertebrates in a eutrophic reservoir: Freshwater Biology, v. 47, p. 1107-1121.

Donat, J.R., Lao, K.A., and Bruland, K.W., 1994, Speciation of dissolved copper and nickel in South San Francisco Bay; a multi-method approach: Analytica Chimica Acta, v. 284, p. 547-571.

Duquesne, S., Newton, L.C., Giusti, L., Marriott, S.B., Stärk, H-J., and Bird, D.J., 2006, Evidence for declining levels of heavy-metals in the Severn Estuary and Bristol Channel, U.K. and their spatial distribution in sediments: Environmental Pollution, v. 143, p. 187-196.

Dyer, K.R., and Manning, A.J., 1999, Observation of the size, settling velocity and effective density of flocs, and their fractal dimensions: Journal of Sea Research, v. 41, p. 87-95.

Edzwald, J.K., and O'Melia, C.R., 1975, Clay distributions in recent estuarine sediments: Clays and Clay Minerals, v. 23, p. 39-44.

Eisma, D., 1986, Flocculation and de-flocculation of suspended matter in estuaries: Netherlands Journal of Sea Research, v. 20, p. 183-199.

Eldridge, S.L., Wood, T.M., Kannarr, K.E., Echols, K.R., and Topping, B.R., 2014, Microcystins, nutrient dynamics, and other environmental factors during blooms of non-microcystin-producing Aphanizomenon flos-aquae in Upper Klamath lake, Oregon, 2009: Lake and Reservoir Management, v. 29, p. 68-81.

Essaid, H.I., Zamora, C.M., McCarthy, K.A., Vogel, J.R., and Wilson, J.T., 2008, Using heat to characterize streambed water flux variability in four stream reaches: Journal of Enviromental Quality, v. 37, p. 1010-1023.

Falter, M.A., and Cech, J.J., Jr., 1991, Maximum pH tolerance of three Klamath Basin fishes: Copeia, v. 1991, no. 4, p. 1109-1111. 
Feely, R.A., Trefry, J.H., Lebon, G.T., German, C.R., 1998, The relationship between P/Fe and V/Fe ratios in hydrothermal precipitates and dissolved phosphate in seawater: Geophysical Research Letters, v. 25, p. 2253-2256.

Fennessy, M.J., Dyer, K.R., Huntley, D.A., and Bale, A.J., 1997, Estimation of settling flux spectra in estuaries using INSSEV, in Burt, N., Parker, R., and Watts, J., eds., Cohesive Sediments Proceedings of INTERCOH Conference [Wallingford, England]: Chichester, U.K., John Wiley \& Son, , p. 87-104.

Fisher, L.H., and Wood, T.M., 2001, Effect of water-column pH on sediment-phosphorus release rates in Upper Klamath Lake, Oregon: U.S. Geological Survey Water-Resources Investigations Report 034271, 25 p., accessed at http://pubs.usgs.gov/wri/wri034271/.

Fitzwater, S.E., Knauer, G.A., and Martin, J.H., 1982, Metal contamination and its effects on primary production measurements: Limnology and Oceanography, v. 27, p. 544-551.

Franson, M.A.H., 1985, Standard Methods for the Examination of Water and Wastewater (16th ed.): Washington D.C., American Public Health Association, 1268 p.

Frome, E.L., and Watkins, J.W., 2004, Statistical analysis of data with non-detectable values: Oak Ridge National Laboratories, U.S. Department of Energy, ORNL/TM-2004/146, 28 p.

Fukuhara, H., and Sakamoto, M., 1987, Enhancement of inorganic nitrogen and phosphate release from lake sediment by tubificid worms and chironomid larvae: Oikos, v. 48, p. 312-320.

Gallepp, G.W., 1979, Chironomid influence on phosphorus release in sediment-water microcosms: Ecology, v. 60, p. 547-556.

Gannett, M.W., Lite, K.E., Jr., La Marche, J.L., Fisher, B.J., and Polette, D.J., 2007, Ground-water hydrology of the upper Klamath Basin, Oregon and California: U.S. Geological Survey Scientific Investigations Report 2007-5050, 84 p.

Gardner, W.S., Nalepa, T.F., Quigley, M.A., and Malczyk, J.M., 1981, Release of phosphorus by certain benthic invertebrates: Canadian Journal of Fisheries and Aquatic Sciences, v. 38, p. 978-981.

Gerbersdorf, S.U., Bittner, R., Lubarsky, H., Manz, W., and Paterson, D.M., 2009, Microbial assemblages as ecosystem engineers of sediment stability: Journal of Soils and Sediments, v. 9, p. 640-652.

Goldberg, S.A., 1985, Chemical modeling of anion competition on goethite using the constant capacitance model: Soil Science Society of America Journal, v. 49, p. 851-856.

Gowland, J.E., Mehta, A.J., Stuck, J.D., John, C.V., and Parchure, T.M.. 2007, Organic-rich fine sediments in Florida, Part II-Resuspension in a lake: Proceedings in Marine Science, v. 8, p. 162183.

Grabowski, R.C., Droppo, I.G., and Wharton, G., 2011, Erodibility of cohesive sediment; The importance of sediment properties: Earth-Science Reviews, v. 105, p. 101-120.

Gratiot, N., and Manning, A.J., 2004, An experimental investigation of floc characteristics in a diffusive turbulent flow: Journal of Coastal Research, v. SI 41, 105-113.

Harita, Y., Hori, T., and Sugiyama, M., 2005, Release of trace oxyanions from littoral sediments and suspended particles induced by $\mathrm{pH}$ increase in the epilimnion of lakes: Limnology and Oceanography, v. 50, p. 636-645.

Hazel, C.R., 1969, Limnology of Upper Klamath Lake, Oregon, with emphasis on benthos: Corvallis, Oregon State University, Ph.D. dissertation.

Hogfeldt, E., 1982, Stability constants of metal ion complexes, Pt A-Inorganic ligands: Oxford, Oxfordshire, U.K., Pergammon Press, 310 p. 
Hoilman, G.R., Lindenberg, M.K., and Wood, T.M., 2008, Water quality conditions in Upper Klamath and Agency Lakes, Oregon, 2005: U.S. Geological Survey Scientific Investigations Report 20085026, 44 p., accessed at http://pubs.usgs.gov/sir/2008/5026/.

Istvánovics, V., 2008, The role of biota in shaping the phosphorus cycle in lakes: Freshwater Reviews, v. 1, p. 143-174.

Ji, L., Song, C., Cao, X., Zhou, Y., and Deng, D., 2015, Spatial variation in nutrient excretion by macrozoobenthos in a Chinese large shallow lake (Lake Taihu): Journal of Freshwater Ecology, v. 30, p. $169-180$.

Kann, J., 2006, Microcystis aeruginosa; occurrence in the Klamath River system of southern Oregon and northern California: Yurok Tribe Environmental and Fisheries Programs, 26 p., accessed September 28,2016 , at

http://www.waterboards.ca.gov/water_issues/programs/tmdl/records/region_1/2007/ref2828.pdf.

Kann, J., 2010, Upper Klamath Lake 2009 data summary report: Chiloquin, Oreg., Klamath Tribes, 47 p.

Kann, J., and Welch, J.B., 2005, Wind control on water quality in shallow, hypereutrophic Upper Klamath Lake, Oregon: Lake and Reservoir Management, v. 21, no. 2, p. 149-158.

Kathman, R.D., and Brinkhurst, R.O., 1998, Guide to the freshwater oligochaetes of North America: College Grove, Tennessee, Aquatic Resources Center, 264 p.

Klump, J.V., and Martens, C.S., 1981, Biogeochemical cycling in an organic rich coastal marine basin-II, Nutrient sediment-water exchange processes: Geochimica et Cosmochimica Acta, v. 45, p. 101-121.

Koch, F.W., Voytek, E.B., Day-Lewis, F.D., Healy, R., Briggs, M.A., Lane, J.W. and Werkema, D., 2015, 1DTempPro V2-New features for inferring groundwater/surface-water exchange:

Groundwater, doi:10.1111/gwat.12369, accessed September 28, 2016, at https:/water.usgs.gov/ogw/bgas/1dtemppro/1DTempProV2-GroundWater2015.pdf.

Kranck, K., and Milligan, T.G., 1992, Characteristics of suspended particles at an 11-hour anchor station in San Francisco Bay, California: Journal of Geophysical Research, v. 97, p. 11373-11382.

Kranenburg, C., 1994, The fractal structure of cohesive sediment aggregates: Estuarine, Coastal and Shelf Science, v. 39, p. 451-460.

Kuwabara, J.S., Berelson, W.M., Balistrieri, L.S., Woods, P.F., Topping, B.R., Steding, D.J., and Krabbenhoft, D.P., 2000, Benthic flux of metals and nutrients into the water column of Lake Coeur d'Alene, Idaho; Report of an August, 1999 pilot study: U.S. Geological Survey Water-Resources Investigations Report 00-4132, 74 p., accessed at http:/water.usgs.gov/pubs/wri/wri004132/.

Kuwabara, J.S., Davis, J.A., and Chang, C.C.Y., 1986, Algal growth response to particle bound orthophosphate and zinc: Limnology and Oceanography, v. 31, p. 503-511.

Kuwabara, J.S., and Leland, H.V., 1986, Adaptation by Selenastrum capricornutum (Chlorophyceae) to copper: Environmental Toxicology and Chemistry, v. 5, p. 197-203.

Kuwabara, J.S., Lynch, D.D., Topping, B.R., Murphy, F., Carter, J.L., Simon, N.S., Parchaso, F., Wood, T.M., Lindenberg, M.K., Wiese, K., and Avanzino, R.J., 2007, Quantifying the benthic source of dissolved nutrients to the water column of Upper Klamath Lake, Oregon: U.S. Geological Survey Open-File Report 2007-1276, 40 p., accessed at http://pubs.usgs.gov/of/2007/1276/.

Kuwabara, J.S., Topping, B.R., Carter, J.L., Wood, T.M., Cameron, J.M., Asbill-Case, J.R., and Carlson, R.A., 2012a, Changes in benthic nutrient sources within a wetland after hydrologic reconnection: Environmental Toxicology and Chemistry, v. 31, p. 1995-2013.

Kuwabara, J.S., Topping, B.R., Carter, J.L., Wood, T.M., Parchaso, F., Cameron, J.M., Asbill-Case, J.R., Carlson, R.A., and Fend, S.V., 2012b, Time scales of change in chemical and biological 
parameters after engineered levee breaches adjacent to Upper Klamath and Agency Lakes, Oregon: U.S. Geological Survey Open-file Report 2012-1057, 36 p., accessed at http://pubs.usgs.gov/of/2012/1057/.

Kuwabara, J.S., Topping, B.R., Coale, K.H., and Berelson, W.M., 1999, Processes affecting the benthic flux of trace metals into the water column of San Francisco Bay, in Morganwalp, D.W., and Buxton, H.T., eds., U.S. Geological Survey Toxic Substances Hydrology Program Technical Meeting: Charleston, S.C., U.S. Geological Survey Water-Resources Investigations Report 99-4018B, p. 115119, http://toxics.usgs.gov/pubs/wri99-

4018/Volume2/sectionA/2214_Kuwabara/pdf/2214_Kuwabara.pdf.

Kuwabara, J.S., Topping, B.R., Lynch, D.D., Carter, J.L., and Essaid, H.I., 2009, Benthic nutrient sources to hypereutrophic Upper Klamath Lake, Oregon: Environmental Toxicology and Chemistry, v. 28, p. 516-524.

Kuwabara, J.S., Woods, P.F., Berelson, W.M., Balistrieri, L.S., Carter, J.L., Topping, B.R., and Fend, S.V., 2003, Importance of sediment-water interactions in Coeur d'Alene Lake, Idaho; management implications: Environmental Management, v. 32, p. 348-359.

Lapham, W.W., 1989, Use of temperature profiles beneath streams to determine rates of vertical ground-water flow and vertical hydraulic conductivity: U.S. Geological Survey Water Supply Paper 2337, $35 \mathrm{p}$.

Lead, J.R., Wilkinson, K.J., Starchev, K., Canonica, S., and Buffle, J., 2000, Determination of diffusion coefficients of humic substances by fluorescence correlation spectroscopy; Role of solution conditions: Environment Science and Technology, v. 34, p. 1365-1369.

Li, Y.-H., and Gregory, S., 1974, Diffusion of ions in sea water and in deep-sea sediments: Geochimica et Cosmochimica Acta, v. 38, p. 703-714.

Lick, W., Huang, H. and Jepsen, R., 1993, Flocculation of fine-grained sediments due to differential settling: Journal of Geophysical Research, v. 98, no. C6, p. 10279-10288.

Lick, W., and Lick, J., 1988, On aggregation and disaggregation of fine grained lake sediments: Journal of Great Lakes Research, v. 14, no. 4, p. 514-523.

Light, B.R., and John, B., 1998, Distribution and spatial variation of benthic microalgal biomass in a temperate, shallow-water marine system: Aquatic Botany, v. 61, p. 39-54.

Lindenberg, M.K., Hoilman, Gene, and Wood, T.M., 2009, Water quality conditions in Upper Klamath and Agency Lakes, Oregon, 2006: U.S. Geological Survey Scientific Investigations Report 20085201, 54 p., accessed at http://pubs.usgs.gov/sir/2008/5201/.

Little, C., 2000, The biology of soft shores and estuaries: Oxford University Press, 252p.

Malarkey, J., Baas, J.H., Hope, J.A., Aspden, R.J., Parsons, D.R., Peakall, J., Paterson, D.M., Schindler, R.J., Ye, L., Lichtman, I.D., Bass, S.J., Davies, A.G., Manning, A.J., and Thorne, P.D., 2015, The pervasive role of biological cohesion in bedform development: Nature Communications, v. 6, article 6257, doi: $10.1038 /$ ncomms 7257.

Manning, A.J., 2001, A study of the effects of turbulence on the properties of flocculated mud: Plymouth, U.K., University of Plymouth, Institute of Marine Studies, Ph.D. thesis., 282p.

Manning, A.J., 2004, Observations of the properties of flocculated cohesive sediment in three western European estuaries: Journal of Coastal Research, Special Issue SI 41, p. 70-81.

Manning, A.J., 2006, LabSFLOC - A laboratory system to determine the spectral characteristics of flocculating cohesive sediments: HR Wallingford Technical Report, TR 156.

Manning, A.J., Baugh, J.V., Soulsby, R.L., Spearman, J.R., and Whitehouse, R.J.S., 2011, Cohesive sediment flocculation and the application to settling flux modelling, in Ginsberg, Silvia Susana, ed., Sediment transport: Vienna, InTech, Chapter 5, p. 91-116, doi:org/10.5772/16055, accessed at 
http://www.intechopen.com/books/sediment-transport/cohesive-sediment-flocculation-and-theapplication-to-settling-flux-modelling.

Manning, A.J., and Dyer, K.R., 2007, Mass settling flux of fine sediments in Northern European estuaries-Measurements and predictions: Marine Geology, v. 245, p. 107-122, doi:10.1016/j.margeo.2007.07.005.

Manning, A.J., van Kessel, T., Melotte, J., Sas, M., Winterwerp, J.C., and Pidduck, E.L., 2010a, On the consequence of a new tidal dock on the sedimentation regime in the Antwerpen area of the Lower Sea Scheldt: Continental Shelf Research, v. 31, p. S150-S164, doi:10.1016/j.csr.2010.10.008.

Manning, A.J., and Schoellhamer, D.H., 2013, Factors controlling floc settling velocity along a longitudinal estuarine transect: Marine Geology, San Francisco Bay Special Issue, v. 345, p. 266-280, accessed at http://dx.doi.org/10.1016/j.margeo.2013.06.018.

Manning, A.J., Schoellhamer, D.H., Mehta, A.J., Nover, D. and Schladow, S.G., 2010b, Video measurements of flocculated sediment in lakes and estuaries in the USA: Proceedings of the Joint Federal Interagency Conference on Sedimentation and Hydrologic Modeling, Riviera Hotel, Las Vegas, Nev., June 27-July 1, 2010, 12 p.

Manning, A.J., Spearman, J.R., Whitehouse, R.J.S., Pidduck, E.L., Baugh, J.V., and Spencer, K.L., 2013, Laboratory assessments of the flocculation dynamics of mixed mud/sand suspensions, in Manning, A.J., ed., Sediment transport processes and their modelling applications: Rijeka, Croatia, InTech, Chapter 6, p. 119-164, doi:org/10.5772/3401, accessed at http://www.intechopen.com/books/sediment-transport-processes-and-their-modellingapplications/flocculation-dynamics-of-mud-sand-mixed-suspensions.

Martin, A.J., and Pedersen, T.F., 2002, Seasonal and interannual mobility of arsenic in a lake impacted by metal mining: Environmental Science and Technology, v. 36, p. 1516-1523.

Martin, E.A., and Rice, C.A., 1981, 210Pb geochronology and trace metal concentrations of sediments from Upper Klamath Lake and Lake Euwana, Oregon: Northwest Science, v. 55, no. 4, p. 269-280.

Martin, B.A., and Saiki, M.K., 1999, Effects of ambient water quality on the endangered Lost River sucker in Upper Klamath Lake, Oregon: Transactions of the American Fisheries Society, v. 128, p. 953-961.

Mehta, A.J., 2014, An introduction to hydraulics of fine sediment transport: Hackensack, N.J., World Scientific, Advanced Series on Ocean Engineering, v. 38, 1060 p.

Mehta, A.J., Hwang, K.-N., and Khare, Y.P., 2015, Critical shear stress for mass erosion of organic-rich fine sediments: Estuarine, Coastal and Shelf Science, v. 65, p. 97-103.

Mehta, A.J., Jaeger, J.M., Valle-Levinson, A., Hayter, E.J., Wolanski, E., and Manning, A.J., 2009, Resuspension dynamics in Lake Apopka, Florida: Final Synopsis Report, St. Johns River Water Management District, Report No. UFL/COEL-2009/00, 158p.

Meyer, J.S., and Hansen, J.A., 2002, Subchronic toxicity of low dissolved oxygen concentrations, elevated $\mathrm{pH}$ and elevated ammonia concentrations to Lost River suckers: Transactions of the American Fisheries Society, v. 131, p. 656-666.

Mietta, F., Chassagne, C., Manning, A.J., and Winterwerp, J.C., 2009, Influence of shear rate, organic matter content, $\mathrm{pH}$ and salinity on mud flocculation: Ocean Dynamics, v. 59, p. 751-763, doi:10.1007/s10236-009-0231-4.

Miller, W.E., and Tash, J.C., 1967, Interim report, Upper Klamath Lake studies, OR: Federal Water Pollution Control Administration, Pacific Northwest Laboratory, Water Pollution Control Research Series, Paper WP-20-8, 37 p. 
Morace, J.L., 2007, Relation between selected water-quality variables, climatic factors, and lake levels in Upper Klamath and Agency Lakes, Oregon, 1990-2006: U.S. Geological Survey Scientific Investigations Report 2007-5117, 54 p.

Morford, J., and Emerson S., 1999, The geochemistry of redox sensitive trace metals in sediments: Geochimica et Cosmochimica Acta, v. 63, p. 1735-1750.

Moulton, S.R., Carter, J.L., Grotheer, S.A., Cuffney, T.F., and Short, T.M., 2000, Methods of analysis by the U.S. Geological Survey National Water Quality Laboratory-processing, taxonomy, and quality control of benthic macroinvertebrate samples: U.S. Geological Survey Open-File Report 00212.

Nakamura, T., Adachi, Y., and Suzuki, M., 1993, Flotation and sedimentation of a single Microcystis floc collected from surface bloom: Water Research, v. 27, p.979-983.

Odd, N.V.M., 1988, Mathematical modelling of mud transport in estuaries, in Dronkers, J., and van Leussen, W., eds., Physical processes of estuaries: Berlin, Springer, p. 503-531.

Parsons, D.R., Schindler, R.J., Hope, J.A., Malarkey, J., Baas, J.H., Peakall, J., Manning, A.J., Ye, L., Simmons, S., Paterson, D.M., Aspden, R.J., Bass, S.J., Davies, A.G., Lichtman, I.D., and Thorne, P.D., 2016, The role of biophysical cohesion on subaqueous bed form size: Geophysical Research Letters, v. 43, p. 1566-1573, doi:10.1002/2016GL067667.

Postolache, C., Rîşnoveanu, G., and Vădineanu, A., 2006, Nitrogen and phosphorus excreation rates by tubificids from the Prahova River (Romania): Hydrobiologia, v. 533, p. 121-127.

Rahimi, M., Essaid, H.I., and Wilson, J.T., 2015, The role of dynamic surface water-groundwater exchange on streambed denitrification in a first-order, low-relief agricultural watershed: Water Resources Research, v. 51, p. 9514-9538.

Randall, D.J., and Tsui, T.K.N., 2002, Ammonia toxicity in fish: Marine Pollution Bulletin, v. 45, p. 17-23.

Rebreanu, L., Vanderborght, J.-P., and Chou, L., 2008, The diffusion coefficient of dissolved silica revisited: Marine Chemistry, v. 112, p. 230-233.

Reddy, K.R., and DeLaune, R.D., 2008, Biogeochemistry of wetlands-Science and applications: Boca Raton, Fla., CRC Press, 800 p.

Ruttenberg, K.C., 1992, Development of a sequential extraction method for different forms of phosphorus in marine sediments: Limnology and Oceanography, v. 37, p. 1460-1482.

Sereda, J.M., and Hudson, J.J., 2011, Empirical models for predicting the excretion of nutrients (N and $\mathrm{P})$ by aquatic metazonans - taxonomic differences in rates and element ratios: Freshwater Biology, v. 56, p. 250-263.

Shiller, A.M., and Boyle, E.A., 1987, Dissolved vanadium in rivers and estuaries: Earth and Planetary Science Letters, v. 86, p. 214-224

Sigg, L., and Stumm, W., 1981, The interaction of anions and weak acids with the hydrous goethite $(\alpha-$ FeOOH) surface: Colloids and Surfaces, v. 2, p. 101-117.

Sills, G.C., and Elder, D.M., 1986, The transition from sediment suspension to settling bed, in Mehta, A.J., ed., Estuarine cohesive sediment dynamics: New York, Springer, p. 192-205.

Soulsby, R.L., Manning, A.J., Spearman, J., and Whitehouse, R.J.S., 2013, Settling velocity and mass settling flux of flocculated estuarine sediments: Marine Geology, v. 339, p. 1-12, doi:10.1016/j.margeo.2013.04.006.

Stallman, R.W., 1965, Steady one-dimensional fluid flow in a semi-infinite porous medium with sinusoidal surface temperature: Journal of Geophysical Research, v. 70, p. 2821-2827, doi:10.1029/JZ070i012p02821. 
Stauber, J.L., and Florence, T.M., 1987, Mechanism of toxicity of ionic copper and copper complexes to algae: Marine Biology, v. 94, p. 511-519.

Stonestrom, D.A., and Constantz, J., eds., 2003, Heat as a tool for studying the movement of ground water near streams: U.S. Geological Survey Circular 1260, 96 p.

Sullivan, A.B., and Rounds, S.A., 2016, Modeling water quality, temperature, and flow in Link River, south-central Oregon: U.S. Geological Survey Open-File Report 2016-1146, 31 p., http://dx.doi.org/10.3133/ofr20161146.

Tambo, N., and Watanabe, Y., 1979, Physical characteristics of flocs-I; The floc density function and aluminium floc: Water Research, v. 13, p. 409-419.

Thorne, L.T., and Nickless, G., 1981, The relation between heavy metals and particle size fractions within the Severn Estuary (U.K.) inter-tidal sediments: Science of the Total Environment, v. 19, p. 207-213.

Thompson, J.K., Nichols, F.H., and Wienke, S.M., 1981, Distribution of benthic chlorophyll in San Francisco Bay, California, February 1980-February 1981: U.S. Geological Survey Open File Report 81-1134, $55 \mathrm{p}$.

Tolhurst, T.J., Gust. G., and Paterson, D.M., 2002, The influence on an extra-cellular polymeric substance (EPS) on cohesive sediment stability, in Winterwerp, J.C., and Kranenburg, C., eds, Fine sediment dynamics in the marine environment: Amsterdam, Elsevier, Proceedings in Marine Science 5, p. 409-425.

Topping, B.R., and Kuwabara, J.S., 1999, Flow-injection-ICP-MS method applied to benthic flux studies of San Francisco Bay, in Morganwalp, D.W., and Buxton, H.T., eds., U.S. Geological Survey Toxic Substances Hydrology Program Technical Meeting, Charleston, S.C.: U.S. Geological Survey Water-Resources Investigations Report 99-4018B, p. 131-134, http://toxics.usgs.gov/pubs/wri994018/Volume2/sectionA/2216_Topping/index.html.

Topping, B.R., and Kuwabara, J.S., 2003, Dissolved nickel and benthic flux in South San Francisco Bay; a potential for natural sources to dominate: Bulletin of Environmental Contamination and Toxicology, v. 71, p. 46-51.

U. S. Environmental Protection Agency, 2000, Nutrient criteria technical guidance manual—rivers and streams: Washington D.C., Office of Science and Technology, EPA-822-B-00-002.

U.S. Geological Survey, 2016, Klamath Lake water data: U.S. Geological Survery National Water Information System Web site, accessed July 21, 2016, at http://waterdata.usgs.gov/nwis/inventory/?site_no=422622122004000.

Vandenbruwane, J., De Neve, S., Qualls, R.G., Sleutel, S., and Hofman, G., 2007, Comparison of different isotherm models for dissolved organic carbon (DOC) and nitrogen (DON) sorption to mineral soil: Geoderma, v. 139, p. 144-153.

Wetzel, R.G., 2001, Limnology (3d ed.): London, Academic Press, 1006 p.

Wherry, S.A., Wood, T.M., and Anderson, C.W., 2015, Revision and proposed modification of a total maximum daily load model for Upper Klamath Lake, Oregon: U.S. Geological Survey Scientific Investigations Report 2015-5041, 55 p., http://dx.doi.org/10.3133/sir20155041.

Winterwerp, J.C., Manning, A.J., Martens, C., de Mulder, T., and Vanlede, J., 2006, A heuristic formula for turbulence-induced flocculation of cohesive sediment: Estuarine, Coastal \& Shelf Science, v. 68, p. 195-207.

Wolanski, E., 2007, Estuarine ecohydrology (1st ed.): Amsterdam, Elsevier, 186 p.

Wong, S.W., Barry, M.J., Aldous, A.R., Rudd, N.T., Hendrixson, H.A., and Doehring, C.M., 2011, Nutrient release from a recently flooded delta wetland-Comparison of field measurements to laboratory results: Wetlands, v. 31, p. 433-443. 
Wood, T.M., and Gartner, J.W., 2010, Use of acoustic backscatter and vertical velocity to estimate concentration and dynamics of suspended solids in Upper Klamath Lake, south-central OregonImplications for Aphanizomenon flos-aquae: U.S. Geological Survey Scientific Investigations Report 2010-5203, 20 p., accessed at http://pubs.usgs.gov/sir/2010/5203/.

Wood, T.M., Hoilman, G.R., and Lindenberg, M.K., 2006, Water-quality conditions in Upper Klamath Lake, Oregon, 2002-04: U.S. Geological Survey Scientific Investigations Report 2006-5209, 54 p., accessed at http://pubs.usgs.gov/sir/2006/5209/.

Wood, T.M., Wherry, S.A., Carter, J.L., Kuwabara, J.S., Simone, N.S., and S.A. Rounds, 2013, Technical evaluation of a total maximum daily load model for Upper Klamath and Agency Lakes, Oregon: U.S. Geological Survey Open-File Report 2013-1262, 75 p., accessed at http://pubs.usgs.gov/of/2013/1262/. 


\section{Tables}

Table 1. Sampling site locations and descriptions within and up gradient of Upper Klamath Lake, Oregon. See also figure 1.

\begin{tabular}{|c|c|c|c|}
\hline Site & Description & Latitude & Longitude \\
\hline \multicolumn{2}{|c|}{ Lake sites } & \multicolumn{2}{|c|}{ WGS 84 Datum } \\
\hline MDN & Mid-lake north & N42.4391 & W122.0122 \\
\hline MDT & Mid-lake trench & N42.3848 & W121.9272 \\
\hline ML & Mid-lake & N42.3847 & W121.8664 \\
\hline SPR & Spring within Lake & N42.3988 & W121.8212 \\
\hline LN01 & Littoral north 1 & N42.4901 & W122.0023 \\
\hline LN02 & Littoral north 2 & N42.4294 & W122.0387 \\
\hline LN03 & Littoral north 3 & N42.4057 & W122.0034 \\
\hline ON01 & Open-lake north 1 & $\mathrm{~N} 42.4051$ & W122.0206 \\
\hline ON02 & Open-lake north 2 & $\mathrm{~N} 42.4362$ & W121.9715 \\
\hline ON03 & Open-lake north 3 & N42.4368 & W122.0444 \\
\hline $\mathrm{LC} 01$ & Littoral central 1 & N42.4613 & W121.9309 \\
\hline $\mathrm{LC} 02$ & Littoral central 2 & $\mathrm{~N} 42.4472$ & W121.8802 \\
\hline $\mathrm{LC} 03$ & Littoral central 3 & N42.4626 & W121.9041 \\
\hline OC01 & Open-lake central 1 & $\mathrm{~N} 42.4219$ & W121.8866 \\
\hline $\mathrm{OC} 02$ & Open-lake central 2 & N42.4170 & W121.8503 \\
\hline $\mathrm{OC} 03$ & Open-lake central 3 & $\mathrm{~N} 42.4217$ & W121.8684 \\
\hline LS01 & Littoral south 1 & $\mathrm{~N} 42.3368$ & W121.9367 \\
\hline LS02 & Littoral south 2 & $\mathrm{~N} 42.3323$ & W121.9368 \\
\hline LS03 & Littoral south 3 & $\mathrm{~N} 42.3439$ & W121.9254 \\
\hline OS01 & Open-lake south 1 & N42.2864 & W121.8526 \\
\hline OS02 & Open-lake south 2 & $\mathrm{~N} 42.3586$ & W121.8635 \\
\hline OS03 & Open-lake south 3 & $\mathrm{~N} 42.3200$ & W121.8964 \\
\hline TR01 & Trench 1 & N42.3679 & W121.8937 \\
\hline TR02 & Trench 2 & N42.3918 & W121.9350 \\
\hline TR03 & Trench 3 & N42.4179 & W121.9414 \\
\hline \multicolumn{4}{|c|}{ Inlet tributary sites } \\
\hline & Sprague River & N42.5864 & W121.8373 \\
\hline & Spring Creek & $\mathrm{N} 42.6412$ & W121.8774 \\
\hline & Williamson River & N42.7403 & W121.8342 \\
\hline & Wood River & N42.6464 & W121.9948 \\
\hline
\end{tabular}


Table 2. Summary of results from 2013 sonde deployments in Upper Klamath Lake, Oregon.

$\left[\mathrm{m}\right.$, meter; $\mu \mathrm{S} \mathrm{cm}^{-1}$, microsiemen per centimeter; \% DO, percent dissolved oxygen; $\mathrm{mg} \mathrm{L}^{-1}$, milligram per liter; na, data from that period is not available. Times listed are Pacific Standard Time. Slightly darkened rows in the table for June 13, 2013, are provided to help the reader distinguish between results relative to sampling dates]

\begin{tabular}{|c|c|c|c|c|c|c|c|c|c|}
\hline Date & Site & Time & $\begin{array}{c}\text { Depth } \\
\text { m }\end{array}$ & $\begin{array}{c}\text { Specific } \\
\text { conduc- } \\
\text { tivity } \\
\mu \mathrm{S} \mathrm{cm}^{-1}\end{array}$ & $\begin{array}{r}\text { Temp. } \\
{ }^{\circ} \mathrm{C} \\
\end{array}$ & $\begin{array}{c}\% \text { DO } \\
\text { saturation } \\
\text { (local) }\end{array}$ & $\begin{array}{c}\text { Vertical \% } \\
\text { DO } \\
\text { saturation } \\
\text { decrease (\%) }\end{array}$ & $\begin{array}{c}\text { DO } \\
\text { concen- } \\
\text { tration } \\
\left(\mathrm{mg} \mathrm{L}^{-1}\right)\end{array}$ & $\mathrm{pH}$ \\
\hline \multirow[t]{2}{*}{$5 / 1 / 13$} & MDN & $13: 00$ & 0.0 & 94 & 11.8 & 102.2 & 7.6 & 9.0 & 6.9 \\
\hline & & & 3.6 & 109 & 11.6 & 94.6 & & 8.4 & 6.8 \\
\hline \multirow[t]{2}{*}{$5 / 1 / 13$} & MDT & $9: 54$ & 0.0 & 100 & 11.9 & 95.2 & 3.5 & 9.3 & 7.1 \\
\hline & & & 14.1 & 100 & 11.3 & 91.7 & & 9.1 & 7.0 \\
\hline \multirow[t]{2}{*}{$5 / 23 / 13$} & LN01 & $15: 01$ & 0.0 & 105 & 14.1 & 99.0 & -1.8 & 8.8 & 8.1 \\
\hline & & & 2.1 & 106 & 12.3 & 100.8 & & 9.3 & 7.8 \\
\hline \multirow[t]{2}{*}{$5 / 23 / 13$} & LN02 & $13: 34$ & 0.0 & 106 & 13.7 & 100.7 & 1.9 & 9.0 & 8.1 \\
\hline & & & 1.9 & 106 & 13.3 & 98.8 & & 8.9 & 7.8 \\
\hline \multirow[t]{2}{*}{$5 / 23 / 13$} & LN03 & $12: 33$ & 0.0 & 107 & 13.2 & 98.3 & 2.0 & 8.9 & 8.0 \\
\hline & & & 1.7 & 107 & 13.1 & 96.3 & & 8.7 & 7.8 \\
\hline \multirow[t]{2}{*}{$5 / 23 / 13$} & ON01 & $12: 59$ & 0.0 & 106 & 13.3 & 101.8 & 2.0 & 9.2 & 8.2 \\
\hline & & & 2.6 & 106 & 13.1 & 99.8 & & 9.0 & 7.8 \\
\hline \multirow[t]{2}{*}{$5 / 23 / 13$} & ON02 & $11: 58$ & 0.0 & 106 & 12.7 & 99.3 & 0.3 & 9.1 & 8.2 \\
\hline & & & 3.4 & 106 & 12.7 & 99.0 & & 9.0 & 7.5 \\
\hline \multirow[t]{2}{*}{$5 / 23 / 13$} & ON03 & 14:01 & 0.0 & 106 & 13.9 & 101.1 & 5.8 & 9.0 & 8.1 \\
\hline & & & 2.4 & 106 & 13.4 & 95.3 & & 8.6 & 7.8 \\
\hline \multirow[t]{2}{*}{$5 / 23 / 13$} & LC01 & $15: 35$ & 0.0 & 105 & 13.6 & 100.9 & -1.5 & 9.0 & 8.1 \\
\hline & & & 1.5 & 106 & 12.3 & 102.4 & & 9.4 & 7.9 \\
\hline \multirow[t]{2}{*}{$5 / 23 / 13$} & LC02 & $16: 19$ & 0.0 & 215 & 14.6 & 101.7 & 6.6 & 8.9 & 8.0 \\
\hline & & & 1.8 & 188 & 12.8 & 95.1 & & 8.7 & 7.7 \\
\hline \multirow[t]{2}{*}{$5 / 23 / 13$} & $\mathrm{LC} 03$ & $15: 59$ & 0.0 & 168 & 13.3 & 100.4 & 1.4 & 9.0 & 8.0 \\
\hline & & & 1.6 & 159 & 12.8 & 99.0 & & 9.0 & 8.1 \\
\hline \multirow[t]{2}{*}{$5 / 23 / 13$} & OC01 & $9: 58$ & 0.0 & 115 & 12.4 & 61.4 & 3.3 & 6.6 & 8.3 \\
\hline & & & 2.9 & 114 & 12.2 & 58.1 & & 6.2 & 8.2 \\
\hline \multirow[t]{2}{*}{$5 / 23 / 13$} & $\mathrm{OC} 02$ & $10: 31$ & 0.0 & 111 & 14.9 & 62.4 & 6.3 & 6.3 & 8.1 \\
\hline & & & 2.3 & 111 & 13.2 & 56.1 & & 5.9 & 8.0 \\
\hline \multirow[t]{2}{*}{$5 / 23 / 13$} & $\mathrm{OC} 03$ & $10: 16$ & 0.0 & 110 & 13.2 & 59.3 & 2.1 & 6.2 & 8.2 \\
\hline & & & 2.9 & 116 & 12.7 & 57.2 & & 6.1 & 8.1 \\
\hline \multirow[t]{2}{*}{$5 / 23 / 13$} & LS01 & $13: 29$ & 0.0 & 172 & 13.1 & 99.5 & 34.9 & 9.0 & 8.3 \\
\hline & & & 1.7 & 209 & 13.1 & 64.6 & & 5.9 & 8.3 \\
\hline \multirow[t]{2}{*}{$5 / 23 / 13$} & LS02 & $13: 45$ & 0.0 & 204 & 12.3 & 99.3 & -3.7 & 9.2 & 8.3 \\
\hline & & & 1.9 & 205 & 12.6 & 103.0 & & 9.5 & 8.3 \\
\hline \multirow[t]{2}{*}{$5 / 23 / 13$} & LS03 & $13: 10$ & 0.0 & 209 & 13.5 & 100.0 & 49.9 & 9.0 & 8.3 \\
\hline & & & 2.0 & 211 & 13.6 & 50.1 & & 4.5 & 8.3 \\
\hline \multirow[t]{2}{*}{$5 / 23 / 13$} & OS01 & $12: 14$ & 0.0 & 107 & 12.4 & 98.1 & 6.6 & 9.8 & 8.1 \\
\hline & & & 2.5 & 108 & 12.6 & 91.5 & & 8.4 & 8.0 \\
\hline \multirow[t]{2}{*}{$5 / 23 / 13$} & OS02 & $12: 41$ & 0.0 & 107 & 12.5 & 102.3 & 6.7 & 9.4 & 8.1 \\
\hline & & & 2.4 & 106 & 12.5 & 95.6 & & 8.8 & 8.1 \\
\hline
\end{tabular}




\begin{tabular}{|c|c|c|c|c|c|c|c|c|c|}
\hline Date & Site & Time & $\begin{array}{c}\text { Depth } \\
\text { m }\end{array}$ & $\begin{array}{c}\text { Specific } \\
\text { conduc- } \\
\text { tivity }\end{array}$ & $\begin{array}{r}\text { Temp. } \\
{ }^{\circ} \mathrm{C}\end{array}$ & $\begin{array}{c}\% \text { DO } \\
\text { saturation } \\
\text { (local) }\end{array}$ & $\begin{array}{c}\text { Vertical \% } \\
\text { DO } \\
\text { saturation } \\
\text { decrease (\%) }\end{array}$ & $\begin{array}{c}\text { DO } \\
\text { concen- } \\
\text { tration } \\
\left(\mathrm{mg} \mathrm{L}^{-1}\right)\end{array}$ & $\mathrm{pH}$ \\
\hline \multirow[t]{2}{*}{$5 / 23 / 13$} & OS03 & $11: 44$ & 0.0 & 230 & 13.1 & 93.5 & 76.4 & 8.5 & 8.0 \\
\hline & & & 4.1 & 277 & 13.2 & 17.1 & & 1.5 & 7.5 \\
\hline \multirow[t]{2}{*}{$5 / 23 / 13$} & TR01 & $7: 51$ & 0.0 & 113 & 13.2 & 53.3 & -0.2 & 5.6 & 8.1 \\
\hline & & & 6.9 & 113 & 13.1 & 53.5 & & 5.6 & 8.0 \\
\hline \multirow[t]{2}{*}{$5 / 23 / 13$} & TR02 & $8: 46$ & 0.0 & 113 & 13.5 & 58.2 & 2.5 & 6.1 & 8.2 \\
\hline & & & 13.8 & 113 & 13.3 & 55.7 & & 5.8 & 8.1 \\
\hline \multirow[t]{2}{*}{$5 / 23 / 13$} & TR03 & $9: 24$ & 0.0 & 113 & 13.8 & 60.8 & 5.1 & 6.3 & 8.2 \\
\hline & & & 7.7 & 113 & 13.4 & 55.7 & & 5.8 & 8.1 \\
\hline \multirow[t]{2}{*}{$6 / 13 / 13$} & LN01 & $9: 41$ & 0.0 & 110 & 17.1 & 117.2 & 6.3 & 9.7 & 9.3 \\
\hline & & & 2.0 & 108 & 16.7 & 110.9 & & 9.2 & 9.0 \\
\hline \multirow[t]{2}{*}{$6 / 13 / 13$} & LN02 & $9: 00$ & 0.0 & 113 & 17.8 & 122.4 & 4.8 & 10.0 & 9.4 \\
\hline & & & 1.7 & 113 & 17.7 & 117.6 & & 9.6 & 9.0 \\
\hline \multirow[t]{2}{*}{$6 / 13 / 13$} & LN03 & $8: 17$ & 0.0 & 114 & 17.6 & 107.6 & 1.0 & 8.8 & 9.8 \\
\hline & & & 2.0 & 114 & 17.6 & 106.6 & & 8.7 & 9.7 \\
\hline \multirow[t]{2}{*}{$6 / 13 / 13$} & ON01 & $8: 39$ & 0.0 & 116 & 17.4 & 117.5 & 29.3 & 9.7 & 9.4 \\
\hline & & & 2.7 & 119 & 17.6 & 88.2 & & 7.2 & 8.3 \\
\hline \multirow[t]{2}{*}{$6 / 13 / 13$} & ON02 & $7: 42$ & 0.0 & 115 & 17.4 & 123.6 & 19.2 & 10.2 & 9.4 \\
\hline & & & 3.4 & 119 & 17.3 & 104.4 & & 8.6 & 8.1 \\
\hline \multirow[t]{2}{*}{$6 / 13 / 13$} & ON03 & $9: 15$ & 0.0 & 113 & 17.9 & 118.8 & 61.0 & 9.7 & 9.3 \\
\hline & & & 2.9 & 113 & 17.8 & 57.8 & & 4.7 & 7.8 \\
\hline \multirow[t]{2}{*}{$6 / 13 / 13$} & LC01 & $10: 14$ & 0.0 & 112 & 17.6 & 129.1 & 45.1 & 10.6 & 9.5 \\
\hline & & & 1.7 & 111 & 16.3 & 84.0 & & 7.1 & 8.6 \\
\hline \multirow[t]{2}{*}{$6 / 13 / 13$} & LC02 & $10: 51$ & 0.0 & 113 & 18.0 & 125.5 & 12.6 & 10.2 & 9.3 \\
\hline & & & 2.0 & 114 & 17.7 & 112.9 & & 9.2 & 9.2 \\
\hline \multirow[t]{2}{*}{$6 / 13 / 13$} & LC03 & $10: 32$ & 0.0 & 115 & 17.5 & 137.0 & 25.6 & 11.2 & 9.4 \\
\hline & & & 1.9 & 112 & 16.8 & 111.4 & & 9.3 & 8.9 \\
\hline \multirow[t]{2}{*}{$6 / 13 / 13$} & OC01 & $11: 03$ & 0.0 & 128 & 17.7 & 108.2 & 9.6 & 10.3 & na \\
\hline & & & 2.5 & 123 & 17.1 & 98.6 & & 9.5 & na \\
\hline \multirow[t]{2}{*}{$6 / 13 / 13$} & $\mathrm{OC} 02$ & $11: 30$ & 0.0 & 125 & 17.6 & 104.1 & 13.6 & 9.9 & na \\
\hline & & & 2.8 & 315 & 17.5 & 90.5 & & 8.6 & na \\
\hline \multirow[t]{2}{*}{$6 / 13 / 13$} & $\mathrm{OC} 03$ & $11: 14$ & 0.0 & 119 & 17.3 & 104.8 & 14.8 & 10.0 & na \\
\hline & & & 3.1 & 303 & 16.7 & 90.0 & & 8.7 & na \\
\hline \multirow[t]{2}{*}{$6 / 13 / 13$} & LS01 & $13: 36$ & 0.0 & 113 & 17.5 & 114.7 & 18.9 & 9.5 & 9.6 \\
\hline & & & 1.6 & 115 & 17.2 & 95.8 & & 8.0 & 9.5 \\
\hline \multirow[t]{2}{*}{$6 / 13 / 13$} & LS02 & $13: 56$ & 0.0 & 112 & 17.3 & 111.4 & 5.2 & 9.3 & 9.6 \\
\hline & & & 1.8 & 112 & 17.3 & 106.2 & & 8.9 & 9.6 \\
\hline \multirow[t]{2}{*}{$6 / 13 / 13$} & LS03 & $13: 13$ & 0.0 & 116 & 17.8 & 112.3 & 107.5 & 9.3 & 9.6 \\
\hline & & & 1.9 & 114 & 17.6 & 4.8 & & 0.4 & 8.0 \\
\hline \multirow[t]{2}{*}{$6 / 13 / 13$} & OS01 & $12: 14$ & 0.0 & 125 & 16.7 & 99.9 & 3.1 & 8.4 & 9.4 \\
\hline & & & 2.0 & 124 & 16.5 & 96.8 & & 8.2 & 9.3 \\
\hline \multirow[t]{2}{*}{$6 / 13 / 13$} & OS02 & $12: 48$ & 0.0 & 115 & 17.4 & 101.2 & -0.1 & 8.4 & 9.4 \\
\hline & & & 2.1 & 116 & 17.4 & 101.3 & & 8.4 & 9.4 \\
\hline
\end{tabular}




\begin{tabular}{|c|c|c|c|c|c|c|c|c|c|}
\hline Date & Site & Time & $\begin{array}{c}\text { Depth } \\
\mathrm{m}\end{array}$ & $\begin{array}{c}\text { Specific } \\
\text { conduc- } \\
\text { tivity } \\
\mu \mathrm{S} \mathrm{cm}^{-1}\end{array}$ & $\begin{array}{r}\text { Temp. } \\
{ }^{\circ} \mathrm{C} \\
\end{array}$ & $\begin{array}{c}\% \text { DO } \\
\text { saturation } \\
\text { (local) }\end{array}$ & $\begin{array}{c}\text { Vertical \% } \\
\text { DO } \\
\text { saturation } \\
\text { decrease (\%) }\end{array}$ & $\begin{array}{c}\text { DO } \\
\text { concen- } \\
\text { tration } \\
\left(\mathrm{mg} \mathrm{L}^{-1}\right)\end{array}$ & $\mathrm{pH}$ \\
\hline \multirow[t]{2}{*}{$6 / 13 / 13$} & OS03 & $11: 42$ & 0.0 & 143 & 16.8 & 101.0 & 3.9 & 8.5 & 9.4 \\
\hline & & & 3.8 & 138 & 16.4 & 97.1 & & 8.3 & 9.3 \\
\hline \multirow[t]{2}{*}{$6 / 13 / 13$} & TR01 & 9:03 & 0.0 & 110 & 17.5 & 96.2 & 20.3 & 9.1 & 7.0 \\
\hline & & & 6.3 & 117 & 17.0 & 75.9 & & 7.3 & 6.4 \\
\hline \multirow[t]{2}{*}{$6 / 13 / 13$} & TR02 & 9:59 & 0.0 & na & 17.6 & 92.8 & 3.6 & 8.8 & 6.8 \\
\hline & & & 13.8 & na & 17.7 & 89.2 & & 8.4 & 6.9 \\
\hline \multirow[t]{2}{*}{$6 / 13 / 13$} & TR03 & $10: 27$ & 0.0 & na & 18.1 & 103.4 & 13.6 & 9.7 & 7.3 \\
\hline & & & 7.8 & na & 17.9 & 89.8 & & 8.5 & 7.1 \\
\hline \multirow[t]{2}{*}{$7 / 3 / 13$} & LN01 & $13: 18$ & 0.0 & 265 & 25.5 & 140.4 & 86.2 & 11.5 & 9.9 \\
\hline & & & 1.5 & 247 & 22.6 & 54.2 & & 4.7 & 9.5 \\
\hline \multirow[t]{2}{*}{$7 / 3 / 13$} & LN02 & $12: 32$ & 0.0 & 255 & 21.9 & 91.5 & 39.9 & 8.0 & 7.0 \\
\hline & & & 1.3 & 248 & 20.1 & 51.6 & & 4.7 & 9.5 \\
\hline \multirow[t]{2}{*}{$7 / 3 / 13$} & LN03 & $11: 54$ & 0.0 & 312 & 25.8 & 105.5 & 38.3 & 8.6 & 10.2 \\
\hline & & & 1.7 & 260 & 24.7 & 67.2 & & 5.6 & 9.7 \\
\hline \multirow[t]{2}{*}{$7 / 3 / 13$} & ON01 & $12: 19$ & 0.0 & 273 & 24.0 & 112.8 & 87.9 & 9.5 & 10.0 \\
\hline & & & 2.5 & 251 & 20.3 & 24.9 & & 2.3 & 9.3 \\
\hline \multirow[t]{2}{*}{$7 / 3 / 13$} & ON02 & $11: 18$ & 0.0 & 256 & 23.0 & 82.6 & 47.7 & 7.2 & 9.0 \\
\hline & & & 3.3 & 254 & 20.5 & 34.9 & & 3.1 & 9.4 \\
\hline \multirow[t]{2}{*}{$7 / 3 / 13$} & ON03 & $12: 54$ & 0.0 & 275 & 23.3 & 101.2 & 54.6 & 8.6 & 10.0 \\
\hline & & & 2.2 & 248 & 19.8 & 46.6 & & 4.3 & 9.5 \\
\hline \multirow[t]{2}{*}{$7 / 3 / 13$} & LC01 & $13: 39$ & 0.0 & 254 & 24.6 & 114.5 & 75.6 & 9.5 & 9.6 \\
\hline & & & 1.6 & 239 & 21.2 & 38.9 & & 3.5 & 9.5 \\
\hline \multirow[t]{2}{*}{$7 / 3 / 13$} & $\mathrm{LC} 02$ & $14: 17$ & 0.0 & 274 & 23.2 & 119.1 & 4.4 & 10.2 & 9.9 \\
\hline & & & 1.5 & 261 & 21.0 & 114.7 & & 10.2 & 9.9 \\
\hline \multirow[t]{2}{*}{$7 / 3 / 13$} & $\mathrm{LC} 03$ & $14: 06$ & 0.0 & 253 & 23.6 & 118.9 & 81.7 & 10.1 & 9.7 \\
\hline & & & 1.5 & 244 & 20.7 & 37.2 & & 3.3 & 9.5 \\
\hline \multirow[t]{2}{*}{$7 / 3 / 13$} & OC01 & $9: 15$ & 0.0 & 124 & 22.8 & 134.3 & 65.6 & 10.0 & 10.1 \\
\hline & & & 2.5 & 116 & 18.8 & 68.7 & & 5.5 & 9.7 \\
\hline \multirow[t]{2}{*}{$7 / 3 / 13$} & $\mathrm{OC} 02$ & $9: 56$ & 0.0 & 128 & 23.0 & 127.3 & 55.6 & 9.4 & 10.1 \\
\hline & & & 2.7 & 118 & 21.1 & 71.7 & & 5.5 & 9.8 \\
\hline \multirow[t]{2}{*}{$7 / 3 / 13$} & $\mathrm{OC} 03$ & $9: 35$ & 0.0 & 128 & 22.5 & 140.3 & 126.0 & 10.5 & 10.3 \\
\hline & & & 3.4 & 116 & 18.4 & 14.3 & & 1.2 & 9.5 \\
\hline \multirow[t]{2}{*}{$7 / 3 / 13$} & LS01 & $10: 21$ & 0.0 & 174 & 25.7 & na & & na & 10.0 \\
\hline & & & 1.6 & 245 & 23.5 & na & & na & 8.5 \\
\hline \multirow[t]{2}{*}{$7 / 3 / 13$} & LS02 & $10: 38$ & 0.0 & 130 & 26.5 & na & & na & 9.5 \\
\hline & & & 1.6 & 136 & 24.1 & na & & na & 9.3 \\
\hline \multirow[t]{2}{*}{$7 / 3 / 13$} & LS03 & $9: 57$ & 0.0 & 227 & 25.2 & na & & na & 9.1 \\
\hline & & & 1.5 & 373 & 23.6 & na & & na & 8.2 \\
\hline \multirow[t]{2}{*}{$7 / 3 / 13$} & OS01 & 9:02 & 0.0 & 119 & 22.4 & na & & na & 9.6 \\
\hline & & & 2.2 & 206 & 23.3 & na & & na & 9.6 \\
\hline \multirow{2}{*}{$7 / 3 / 13$} & OS02 & 9:36 & 0.0 & na & 23.8 & na & & na & 9.2 \\
\hline & & & 2.2 & na & 23.5 & na & & na & 9.2 \\
\hline
\end{tabular}




\begin{tabular}{|c|c|c|c|c|c|c|c|c|c|}
\hline Date & Site & Time & $\begin{array}{c}\text { Depth } \\
\mathrm{m}\end{array}$ & $\begin{array}{c}\text { Specific } \\
\text { conduc- } \\
\text { tivity } \\
\mu \mathrm{S} \mathrm{cm}^{-1}\end{array}$ & $\begin{array}{r}\text { Temp. } \\
{ }^{\circ} \mathrm{C}\end{array}$ & $\begin{array}{c}\% \text { DO } \\
\text { saturation } \\
\text { (local) }\end{array}$ & $\begin{array}{c}\text { Vertical \% } \\
\text { DO } \\
\text { saturation } \\
\text { decrease (\%) }\end{array}$ & $\begin{array}{c}\text { DO } \\
\text { concen- } \\
\text { tration } \\
\left(\mathrm{mg} \mathrm{L}^{-1}\right)\end{array}$ & $\mathrm{pH}$ \\
\hline \multirow[t]{2}{*}{$7 / 3 / 13$} & OS03 & $8: 34$ & 0.0 & 256 & 24.1 & 45.2 & 41.9 & 3.8 & 9.8 \\
\hline & & & 3.5 & 385 & 22.2 & 3.3 & & 0.3 & 9.5 \\
\hline \multirow[t]{2}{*}{$7 / 3 / 13$} & TR01 & 7:30 & 0.0 & 120 & 23.2 & 74.9 & 2.1 & 5.5 & 9.8 \\
\hline & & & 6.0 & 121 & 22.4 & 72.8 & & 5.5 & 9.6 \\
\hline \multirow[t]{2}{*}{$7 / 3 / 13$} & TR02 & 8:08 & 0.0 & 121 & 23.1 & 111.3 & 108.5 & 8.2 & 9.9 \\
\hline & & & 14.2 & 125 & 19.5 & 2.8 & & 0.2 & 9.5 \\
\hline \multirow[t]{2}{*}{$7 / 3 / 13$} & TR03 & $8: 37$ & 0.0 & 122 & 22.8 & 105.5 & 91.1 & 7.8 & 9.8 \\
\hline & & & 7.9 & 121 & 20.0 & 14.4 & & 1.1 & 9.2 \\
\hline
\end{tabular}


Table 3. 2013 dissolved (0.2-micrometer filtered) macronutrient benthic fluxes from profiler deployments.

$\left[\mathrm{mg} \mathrm{m}^{-2} \mathrm{~d}^{-1}\right.$, milligram per square meter per day; nd, nondetectable benthic flux owing to concentrations from profiler samples that were consistently below

detection limits for that solute.; blank cells, flux values that are not available, typically owing to a problem with profiler deployment; S.D., standard deviation for the specified $\mathrm{n}$ replicates. Slightly darkened rows in the table are provided to help the reader distinguish results between sampling dates]

\begin{tabular}{|c|c|c|c|c|c|c|c|c|c|c|c|c|c|c|c|c|}
\hline \multirow[b]{4}{*}{ Date } & \multirow[b]{4}{*}{ SiteName } & \multicolumn{15}{|c|}{ Diffusive flux } \\
\hline & & \multicolumn{3}{|c|}{$\underline{\mathrm{SRP} \text { as } \mathrm{P}}$} & \multicolumn{3}{|c|}{ Ammonia as $\mathrm{N}$} & \multirow{2}{*}{\multicolumn{2}{|c|}{$\begin{array}{r}\text { Nitrate as N } \\
m g m^{-2} d^{-1}\end{array}$}} & & \multirow{2}{*}{\multicolumn{2}{|c|}{$\frac{\text { Silica as } \mathrm{SiO}_{2}}{\mathrm{mg} \mathrm{m}^{-2} \mathrm{~d}^{-1}}$}} & \multicolumn{4}{|c|}{$\mathrm{DOC}$ as C } \\
\hline & & $\mathrm{mg} \mathrm{m}^{-2}$ & & & $\mathrm{mg} \mathrm{m}^{-2} \mathrm{~d}$ & & & & & & & & & $n g m^{-2} d^{-1}$ & & \\
\hline & & Mean & $\mathrm{n}$ & S.D. & Mean & $\mathrm{n}$ & S.D. & Mean & $\mathrm{n}$ & S.D. & Mean & $\mathrm{n}$ & S.D. & Mean & $\mathrm{n}$ & S.D. \\
\hline $4 / 30 / 13$ & MDN_A & 2.19 & 2 & 0.03 & 10.21 & 2 & 7.16 & -9.61 & 2 & 2.27 & & & & 0.72 & 2 & 0.05 \\
\hline $4 / 30 / 13$ & MDN B & 2.64 & 2 & 0.30 & 17.23 & 2 & 9.11 & -10.82 & 2 & 1.70 & & & & -0.36 & 2 & 0.02 \\
\hline $4 / 30 / 13$ & MDN_C & 1.74 & 2 & 0.06 & 17.11 & 2 & 2.84 & -12.42 & 2 & 0.57 & & & & 0.77 & 2 & 0.87 \\
\hline $4 / 30 / 13$ & TRRecon & 4.55 & 2 & 1.61 & 12.26 & 2 & 1.24 & -2.33 & 2 & 1.62 & & & & 0.61 & 2 & 0.09 \\
\hline $5 / 23 / 13$ & LN01 & 12.73 & 2 & 3.72 & 10.40 & 2 & 3.84 & nd & 2 & & 88.5 & 2 & 15.4 & 0.64 & 2 & 0.10 \\
\hline $5 / 23 / 13$ & LN02 & 11.03 & 2 & 6.91 & 8.38 & 2 & 3.03 & nd & 2 & & 57.5 & 2 & 56.1 & 0.91 & 2 & 0.33 \\
\hline $5 / 23 / 13$ & LN03 & 4.42 & 2 & 0.68 & 17.38 & 2 & 3.51 & nd & 2 & & 188.0 & 2 & 10.1 & 2.15 & 2 & 1.34 \\
\hline $5 / 23 / 13$ & ON01 & 2.86 & 2 & 2.31 & 4.13 & 2 & 1.98 & nd & 2 & & 62.0 & 2 & 28.2 & 0.52 & 2 & 0.26 \\
\hline $5 / 23 / 13$ & ON02 & 2.14 & 2 & 0.27 & 6.69 & 2 & 3.56 & nd & 2 & & 43.5 & 2 & 0.9 & 0.02 & 2 & 0.43 \\
\hline $5 / 23 / 13$ & ON03 & 1.72 & 2 & 0.33 & 6.36 & 2 & 0.68 & nd & 2 & & 76.4 & 2 & 6.5 & -0.18 & 2 & 0.49 \\
\hline $5 / 23 / 13$ & LC01 & 6.71 & 2 & 0.39 & 15.89 & 2 & 0.29 & nd & 2 & & 200.5 & 2 & 2.2 & -0.53 & 2 & 0.25 \\
\hline $5 / 23 / 13$ & $\mathrm{LC} 02$ & 0.13 & 2 & 0.06 & 4.01 & 2 & 0.24 & nd & 2 & & 37.1 & 2 & 11.8 & 0.77 & 2 & 0.58 \\
\hline $5 / 23 / 13$ & $\mathrm{LC} 03$ & 1.90 & 2 & 1.14 & 4.11 & 2 & 0.10 & nd & 2 & & 24.6 & 2 & 16.8 & 0.70 & 2 & 0.01 \\
\hline $5 / 23 / 13$ & OC01 & 1.49 & 2 & 0.43 & 9.63 & 2 & 1.51 & nd & 2 & & 54.1 & 2 & 22.3 & -0.62 & 2 & 0.16 \\
\hline $5 / 23 / 13$ & $\mathrm{OC} 02$ & 0.36 & 2 & 0.45 & 3.01 & 1 & & nd & 2 & & 15.8 & 2 & 17.7 & -0.43 & 2 & 0.13 \\
\hline $5 / 23 / 13$ & OC03 & & & & & & & & & & & & & & & \\
\hline $5 / 23 / 13$ & LS01 & 0.94 & 2 & 0.41 & 6.19 & 2 & 4.29 & nd & 2 & & 52.7 & 2 & 5.0 & -0.87 & 2 & 0.79 \\
\hline $5 / 23 / 13$ & LS02 & 1.33 & 2 & 0.59 & 1.93 & 2 & 1.52 & nd & 2 & & 31.4 & 2 & 8.7 & -0.25 & 2 & 0.13 \\
\hline $5 / 23 / 13$ & LS03 & 0.63 & 2 & 0.37 & 6.61 & 1 & & nd & 2 & & 18.2 & 2 & 4.8 & -0.54 & 2 & 0.19 \\
\hline $5 / 23 / 13$ & OS01 & 1.28 & 2 & 0.16 & 12.13 & 2 & 8.27 & nd & 2 & & 101.6 & 2 & 46.9 & -1.15 & 2 & 0.01 \\
\hline $5 / 23 / 13$ & OS02 & 2.92 & 2 & 3.17 & 4.25 & 2 & 4.08 & nd & 2 & & 145.5 & 2 & 0.9 & -0.09 & 2 & 0.62 \\
\hline $5 / 23 / 13$ & $\mathrm{OS} 03$ & 10.20 & 2 & 1.74 & 9.85 & 2 & 3.58 & nd & 2 & & 145.1 & 2 & 8.7 & 1.22 & 2 & 0.15 \\
\hline $5 / 23 / 13$ & TR01 & 6.12 & 2 & 0.73 & 21.60 & 2 & 6.93 & nd & 2 & & 93.5 & 2 & 8.9 & -0.28 & 2 & 0.08 \\
\hline $5 / 23 / 13$ & TR02 & & & & & & & & & & & & & & & \\
\hline $5 / 23 / 13$ & TR03 & 4.38 & 2 & 0.40 & 10.70 & 2 & 0.18 & nd & 2 & & 90.8 & 2 & 24.0 & -0.44 & 2 & 0.39 \\
\hline
\end{tabular}




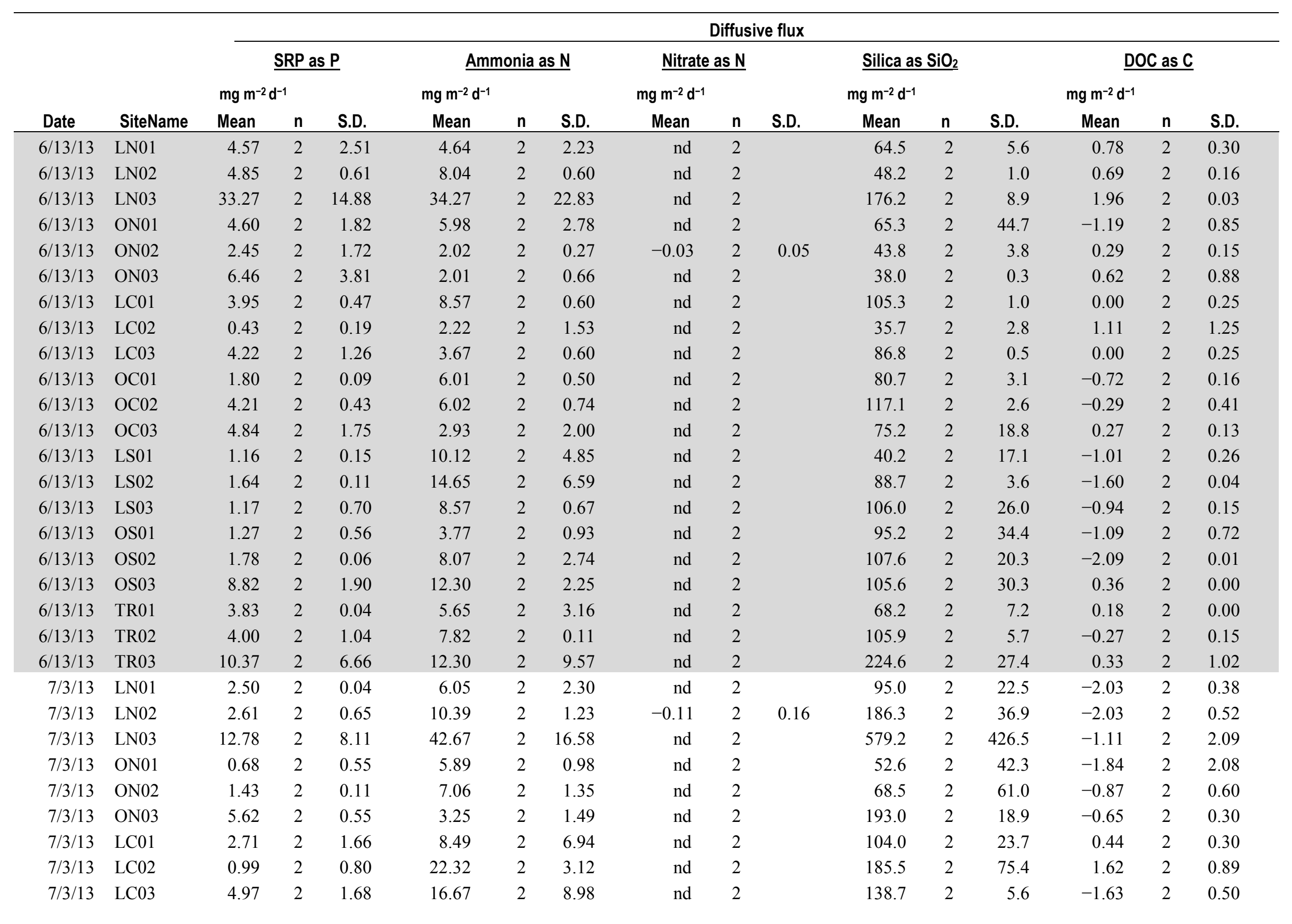




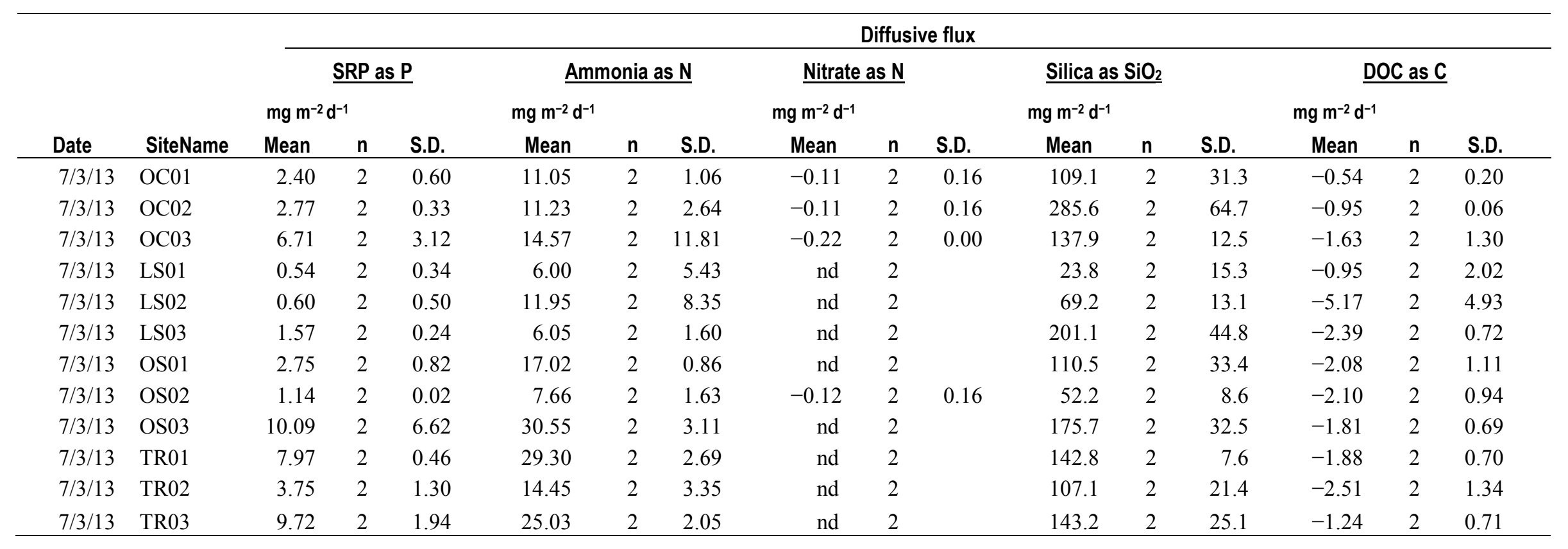


Table 4. Riverine-flux estimates for dissolved (0.2-micrometer filtered) solutes into Upper Klamath Lake, Oregon.

[Available at http://dx.doi.org/10.3133/ofr20161175.] 
Table 5. 2013 dissolved (0.2-micrometer filtered) macronutrient concentrations in the water column of Upper Klamath Lake, Oregon.

[Because the lake is generally shallow (site depths $<3$ meters [m]), water-column samples were collected just below the surface $(\sim 0.5 \mathrm{~m})$, with the exception of the deeper trench (TR) sites (6.0-14.2 m depth). Trench sites were sampled at both the surface and $\sim 1 \mathrm{~m}$ above the lakebed. Blank cells indicate values that are not available. Un-ionized ammonia $\left(\mathrm{NH}_{3}\right)$ concentrations were calculated from temperature and $\mathrm{pH}$ effects on ammonia speciation at their respective depths

(Canadian Council of Ministers of the Environment, 2010). SRP, soluble reactive phosphorus; P, phosphorus; N, nitrogen; DOC, dissolved organic carbon; C, carbon; $\mathrm{m} \mathrm{L}^{-1}$, milligram per liter; S.D. indicates standard deviation for the specified $\mathrm{n}$ replicates; na, data not available from that time period. Slightly darkened rows in the table for June 13, 2013, are provided to help the reader distinguish results between sampling dates]

\begin{tabular}{|c|c|c|c|c|c|c|c|c|c|c|c|c|c|c|c|c|c|}
\hline Date & SiteName & \multicolumn{3}{|c|}{$\begin{array}{l}\text { SRP as } P \\
\mathrm{mg} \mathrm{L}^{-1}\end{array}$} & \multicolumn{3}{|c|}{ Ammonia as $\mathrm{N}$} & $\begin{array}{c}\mathrm{mg} \mathrm{L}^{-1} \\
\text { Un- } \\
\text { ionized }\end{array}$ & \multicolumn{3}{|c|}{$\begin{array}{l}\text { Nitrate as } \mathrm{N} \\
\mathrm{mg} \mathrm{L}^{-1}\end{array}$} & \multicolumn{3}{|c|}{$\begin{array}{l}\text { Silica as } \mathrm{SiO}_{2} \\
\mathrm{mg} \mathrm{L}^{-1}\end{array}$} & \multicolumn{3}{|c|}{$\begin{array}{l}\mathrm{DOC} \text { as C } \\
\mathrm{mg} \mathrm{L}^{-1}\end{array}$} \\
\hline $4 / 30 / 13$ & MDN_A & 0.028 & 2 & 0.000 & 0.205 & 2 & 0.000 & 0.000 & 0.20 & 2 & 0.00 & & & & 3.79 & 2 & 0.03 \\
\hline $4 / 30 / 13$ & MDN_B & 0.028 & 2 & 0.000 & 0.205 & 2 & 0.000 & 0.000 & 0.20 & 2 & 0.00 & & & & & & \\
\hline $4 / 30 / 13$ & MDN_C & 0.028 & 2 & 0.000 & 0.205 & 2 & 0.000 & 0.000 & 0.20 & 2 & 0.00 & & & & & & \\
\hline $4 / 30 / 13$ & TRRecon & 0.290 & 2 & 0.000 & 0.155 & 2 & 0.000 & 0.000 & 0.18 & 2 & 0.00 & & & & 3.84 & 2 & 0.05 \\
\hline $4 / 30 / 13$ & TRRecon & 0.360 & 2 & 0.000 & 0.187 & 2 & 0.000 & 0.001 & 0.18 & 2 & 0.00 & & & & 3.83 & 2 & 0.02 \\
\hline $5 / 23 / 13$ & LN01 & 0.078 & 2 & 0.000 & 0.063 & 2 & 0.001 & 0.002 & $<0.01$ & 2 & & 36.9 & 2 & 0.7 & 4.67 & 2 & 0.02 \\
\hline $5 / 23 / 13$ & LN02 & 0.046 & 2 & 0.001 & 0.048 & 2 & 0.016 & 0.001 & 0.02 & 2 & 0.01 & 37.3 & 2 & 0.8 & 3.77 & 2 & 0.14 \\
\hline $5 / 23 / 13$ & LN03 & 0.047 & 2 & 0.006 & 0.040 & 2 & 0.019 & 0.001 & $<0.01$ & 2 & & 38.0 & 2 & 0.2 & 3.83 & 2 & 0.08 \\
\hline $5 / 23 / 13$ & ON01 & 0.021 & 2 & 0.017 & 0.054 & 2 & 0.008 & 0.002 & $<0.01$ & 2 & & 37.8 & 2 & 0.1 & 3.65 & 2 & 0.09 \\
\hline $5 / 23 / 13$ & ON02 & 0.097 & 2 & 0.070 & 0.037 & 2 & 0.019 & 0.001 & $<0.01$ & 2 & & 37.4 & 2 & 0.0 & 3.58 & 2 & 0.01 \\
\hline $5 / 23 / 13$ & ON03 & 0.048 & 2 & 0.000 & 0.042 & 2 & 0.015 & 0.001 & $<0.01$ & 2 & & 36.5 & 2 & 0.3 & 3.66 & 2 & 0.11 \\
\hline $5 / 23 / 13$ & LC01 & 0.092 & 2 & 0.042 & 0.081 & 2 & 0.019 & 0.002 & $<0.01$ & 2 & & 36.8 & 2 & 0.4 & 3.90 & 2 & 0.06 \\
\hline $5 / 23 / 13$ & LC02 & 0.077 & 2 & 0.015 & 0.035 & 2 & 0.006 & 0.001 & $<0.01$ & 2 & & 36.7 & 2 & 0.7 & 3.89 & 2 & 0.05 \\
\hline $5 / 23 / 13$ & $\mathrm{LC} 03$ & 0.087 & 2 & 0.000 & 0.056 & 2 & 0.009 & 0.001 & $<0.01$ & 2 & & 39.8 & 2 & 0.4 & 3.70 & 2 & 0.06 \\
\hline $5 / 23 / 13$ & OC01 & 0.041 & 2 & 0.001 & 0.061 & 2 & 0.001 & 0.002 & 0.01 & 2 & 0.00 & 38.0 & 2 & 0.1 & 3.64 & 2 & 0.01 \\
\hline $5 / 23 / 13$ & $\mathrm{OC} 02$ & 0.080 & 2 & 0.000 & 0.071 & 2 & 0.033 & 0.002 & 0.01 & 2 & 0.01 & 37.8 & 2 & 0.3 & 3.84 & 2 & 0.00 \\
\hline $5 / 23 / 13$ & $\mathrm{OC} 03$ & 0.164 & 2 & 0.000 & 0.055 & 2 & 0.001 & 0.002 & $<0.01$ & 2 & 0.00 & 36.0 & 2 & 0.3 & 3.76 & 2 & 0.01 \\
\hline $5 / 23 / 13$ & LS01 & 0.042 & 2 & 0.002 & 0.048 & 2 & 0.008 & 0.002 & 0.01 & 2 & 0.01 & 35.3 & 2 & 0.6 & 3.76 & 2 & 0.16 \\
\hline $5 / 23 / 13$ & LS02 & 0.044 & 2 & 0.001 & 0.047 & 2 & 0.008 & 0.002 & $<0.01$ & 2 & 0.00 & 36.0 & 2 & 0.1 & 3.61 & 2 & 0.01 \\
\hline $5 / 23 / 13$ & LS03 & 0.042 & 2 & 0.000 & 0.062 & 2 & 0.001 & 0.003 & $<0.01$ & 2 & 0.00 & 36.0 & 2 & 0.4 & 3.73 & 2 & 0.04 \\
\hline $5 / 23 / 13$ & OS01 & 0.073 & 2 & 0.038 & 0.048 & 2 & 0.010 & 0.001 & $<0.01$ & 2 & 0.00 & 35.8 & 2 & 0.3 & 3.81 & 2 & 0.09 \\
\hline $5 / 23 / 13$ & OS02 & 0.063 & 2 & 0.030 & 0.080 & 2 & 0.041 & 0.002 & $<0.01$ & 2 & 0.00 & 38.6 & 2 & 0.6 & 3.62 & 2 & 0.02 \\
\hline $5 / 23 / 13$ & OS03 & 0.088 & 2 & 0.058 & 0.071 & 2 & 0.007 & 0.002 & $<0.01$ & 2 & 0.00 & 36.9 & 2 & 0.1 & 3.64 & 2 & 0.01 \\
\hline $5 / 23 / 13$ & TR01 & 0.099 & 2 & 0.068 & 0.052 & 2 & 0.002 & 0.002 & $<0.01$ & 2 & 0.00 & 37.6 & 2 & 0.1 & 3.76 & 4 & 0.05 \\
\hline $5 / 23 / 13$ & TR01 & 0.219 & 2 & 0.053 & 0.059 & 2 & 0.001 & 0.001 & $<0.01$ & 2 & 0.00 & 37.6 & 2 & 0.2 & na & & \\
\hline
\end{tabular}




\begin{tabular}{|c|c|c|c|c|c|c|c|c|c|c|c|c|c|c|c|c|c|}
\hline Date & SiteName & \multicolumn{3}{|c|}{$\begin{array}{l}\text { SRP as } P \\
\mathrm{mg} \mathrm{L}^{-1}\end{array}$} & $\begin{array}{l}\mathrm{mg} \mathrm{L}^{-1} \\
\text { Mean }\end{array}$ & Amm & onia as $\mathrm{N}$ & $\begin{array}{c}\mathrm{mg} \mathrm{L}^{-1} \\
\text { Un- } \\
\text { ionized }\end{array}$ & \multicolumn{3}{|c|}{$\begin{array}{l}\text { Nitrate as } \mathrm{N} \\
\mathrm{mg} \mathrm{L}^{-1}\end{array}$} & \multicolumn{3}{|c|}{$\begin{array}{l}\text { Silica as } \mathrm{SiO}_{2} \\
\mathrm{mg} \mathrm{L}^{-1}\end{array}$} & \multicolumn{3}{|c|}{$\begin{array}{l}\mathrm{DOC} \text { as C } \\
\mathrm{mg} \mathrm{L}^{-1}\end{array}$} \\
\hline $5 / 23 / 13$ & TR02 & 0.083 & 2 & 0.045 & 0.078 & 2 & 0.037 & 0.003 & $<0.01$ & 2 & 0.00 & 37.2 & 2 & 0.6 & 3.64 & 2 & 0.01 \\
\hline $5 / 23 / 13$ & TR02 & 0.212 & 2 & 0.079 & 0.035 & 2 & 0.012 & 0.001 & $<0.01$ & 2 & 0.00 & 38.0 & 2 & 0.4 & 3.66 & 2 & 0.01 \\
\hline $5 / 23 / 13$ & TR03 & 0.097 & 2 & 0.054 & 0.044 & 2 & 0.016 & 0.001 & $<0.01$ & 2 & 0.00 & 37.0 & 2 & 1.0 & 3.66 & 2 & 0.00 \\
\hline $5 / 23 / 13$ & TR03 & 0.195 & 2 & 0.042 & 0.057 & 2 & 0.006 & 0.002 & $<0.01$ & 2 & 0.00 & 38.7 & 2 & 0.4 & 3.72 & 2 & 0.08 \\
\hline $6 / 13 / 13$ & LN01 & 0.049 & 2 & 0.001 & $<0.007$ & 2 & & 0.002 & $<0.01$ & 2 & 0.00 & 31.2 & 2 & 0.3 & 3.92 & 2 & 0.02 \\
\hline $6 / 13 / 13$ & LN02 & 0.026 & 2 & 0.005 & 0.029 & 2 & 0.011 & 0.013 & 0.04 & 2 & 0.01 & 33.1 & 2 & 0.3 & 4.07 & 2 & 0.09 \\
\hline $6 / 13 / 13$ & LN03 & 0.018 & 2 & 0.000 & 0.024 & 2 & 0.031 & 0.016 & 0.01 & 2 & 0.00 & 35.5 & 2 & 0.2 & 4.97 & 2 & 0.16 \\
\hline $6 / 13 / 13$ & ON01 & 0.037 & 2 & 0.001 & $<0.007$ & 2 & & 0.002 & 0.01 & 2 & 0.00 & 33.2 & 2 & 0.3 & 4.00 & 2 & 0.01 \\
\hline $6 / 13 / 13$ & ON02 & 0.037 & 2 & 0.001 & 0.008 & 2 & 0.005 & 0.004 & 0.01 & 2 & 0.00 & 33.2 & 2 & 0.1 & 3.88 & 2 & 0.01 \\
\hline $6 / 13 / 13$ & ON03 & 0.033 & 2 & 0.006 & 0.021 & 2 & 0.024 & 0.008 & 0.03 & 2 & 0.01 & 32.8 & 2 & 0.1 & 4.02 & 2 & 0.04 \\
\hline $6 / 13 / 13$ & LC01 & 0.042 & 2 & 0.003 & 0.016 & 2 & 0.001 & 0.008 & 0.02 & 2 & 0.02 & 31.2 & 2 & 0.6 & 4.09 & 2 & 0.02 \\
\hline $6 / 13 / 13$ & LC02 & 0.032 & 2 & 0.002 & 0.008 & 2 & 0.001 & 0.003 & 0.03 & 2 & 0.01 & 31.1 & 2 & 0.4 & 3.95 & 2 & 0.07 \\
\hline 6/13/13 & LC03 & 0.047 & 2 & 0.004 & 0.050 & 2 & 0.059 & 0.023 & 0.03 & 2 & 0.01 & 31.4 & 2 & 0.4 & 3.83 & 2 & 0.01 \\
\hline $6 / 13 / 13$ & OC01 & 0.046 & 2 & 0.001 & $<0.007$ & 2 & & 0.000 & 0.01 & 2 & 0.00 & 31.6 & 2 & 0.6 & 4.11 & 2 & 0.03 \\
\hline $6 / 13 / 13$ & $\mathrm{OC} 02$ & 0.039 & 2 & 0.001 & 0.009 & 2 & 0.000 & 0.000 & 0.01 & 2 & 0.00 & 30.9 & 2 & 0.3 & 4.11 & 2 & 0.03 \\
\hline $6 / 13 / 13$ & $\mathrm{OC} 03$ & 0.045 & 2 & 0.006 & $<0.007$ & 2 & & 0.000 & 0.01 & 2 & 0.00 & 31.4 & 2 & 0.2 & 4.05 & 2 & 0.00 \\
\hline $6 / 13 / 13$ & LS01 & 0.027 & 2 & 0.002 & $<0.007$ & 2 & & 0.002 & 0.01 & 2 & 0.00 & 30.7 & 2 & 0.2 & 4.05 & 2 & 0.03 \\
\hline $6 / 13 / 13$ & LS02 & 0.024 & 2 & 0.003 & 0.014 & 2 & 0.001 & 0.008 & 0.02 & 2 & 0.01 & 31.1 & 2 & 0.1 & 3.96 & 2 & 0.01 \\
\hline $6 / 13 / 13$ & LS03 & 0.028 & 2 & 0.001 & 0.011 & 2 & 0.006 & 0.006 & 0.03 & 2 & 0.01 & 31.7 & 2 & 0.4 & 4.10 & 2 & 0.02 \\
\hline $6 / 13 / 13$ & OS01 & 0.025 & 2 & 0.002 & $<0.007$ & 2 & & 0.002 & 0.01 & 2 & 0.00 & 29.6 & 2 & 0.3 & 4.06 & 2 & 0.12 \\
\hline $6 / 13 / 13$ & OS02 & 0.030 & 2 & 0.003 & $<0.007$ & 2 & & 0.002 & 0.01 & 2 & 0.00 & 33.2 & 2 & 0.6 & 4.03 & 2 & 0.01 \\
\hline $6 / 13 / 13$ & OS03 & 0.027 & 2 & 0.002 & 0.011 & 2 & 0.007 & 0.005 & 0.01 & 2 & 0.00 & 31.0 & 2 & 0.5 & 4.15 & 2 & 0.06 \\
\hline $6 / 13 / 13$ & TR01 & 0.029 & 2 & 0.001 & 0.030 & 2 & 0.024 & 0.000 & 0.03 & 2 & 0.01 & 32.7 & 2 & 0.2 & 4.03 & 2 & 0.01 \\
\hline $6 / 13 / 13$ & TR01 & 0.039 & 2 & 0.001 & 0.021 & 2 & 0.001 & 0.000 & 0.06 & 2 & 0.04 & 33.0 & 2 & 0.1 & 4.03 & 2 & 0.02 \\
\hline $6 / 13 / 13$ & TR02 & 0.027 & 2 & 0.000 & 0.026 & 2 & 0.015 & 0.000 & 0.05 & 2 & 0.00 & 31.8 & 2 & 0.4 & 4.08 & 2 & 0.11 \\
\hline $6 / 13 / 13$ & TR02 & 0.034 & 2 & 0.004 & 0.029 & 2 & 0.001 & 0.000 & 0.06 & 2 & 0.01 & 32.1 & 2 & 0.6 & 3.98 & 2 & 0.05 \\
\hline $6 / 13 / 13$ & TR03 & 0.029 & 2 & 0.002 & 0.009 & 2 & 0.006 & 0.000 & 0.03 & 2 & 0.01 & 31.9 & 2 & 0.6 & 4.07 & 2 & 0.01 \\
\hline $6 / 13 / 13$ & TR03 & 0.035 & 2 & 0.006 & 0.021 & 2 & 0.005 & 0.000 & 0.02 & 2 & 0.01 & 31.8 & 2 & 0.3 & 4.04 & 2 & 0.06 \\
\hline $7 / 3 / 13$ & LN01 & 0.113 & 2 & 0.000 & 0.046 & 2 & 0.001 & 0.037 & 0.01 & 2 & 0.00 & 38.4 & 2 & 0.6 & 5.73 & 2 & 0.01 \\
\hline $7 / 3 / 13$ & LN02 & 0.072 & 2 & 0.002 & 0.051 & 2 & 0.014 & 0.000 & 0.01 & 2 & 0.00 & 35.0 & 2 & 4.6 & 5.42 & 2 & 0.02 \\
\hline $7 / 3 / 13$ & LN03 & 0.020 & 2 & 0.006 & 0.101 & 2 & 0.035 & 0.092 & 0.01 & 2 & 0.00 & 39.1 & 2 & 0.3 & 6.47 & 2 & 0.13 \\
\hline
\end{tabular}




\begin{tabular}{|c|c|c|c|c|c|c|c|c|c|c|c|c|c|c|c|c|c|}
\hline Date & SiteName & \multicolumn{3}{|c|}{$\begin{array}{l}\text { SRP as } P \\
\mathrm{mg} \mathrm{L}^{-1}\end{array}$} & $\begin{array}{l}\mathrm{mg} \mathrm{L}^{-1} \\
\text { Mean }\end{array}$ & Amm & nia as $N$ & $\begin{array}{c}\mathrm{mg} \mathrm{L}^{-1} \\
\text { Un- } \\
\text { ionized }\end{array}$ & \multicolumn{3}{|c|}{$\begin{array}{l}\text { Nitrate as } \mathbf{N} \\
\mathrm{mg} \mathrm{L}^{-1}\end{array}$} & \multicolumn{3}{|c|}{$\begin{array}{l}\text { Silica as } \mathrm{SiO}_{2} \\
\mathrm{mg} \mathrm{L}^{-1}\end{array}$} & \multicolumn{3}{|c|}{$\begin{array}{l}\mathrm{DOC} \text { as C } \\
\mathrm{mg} \mathrm{L}^{-1}\end{array}$} \\
\hline $7 / 3 / 13$ & ON01 & 0.064 & 2 & 0.001 & 0.017 & 2 & 0.001 & 0.014 & 0.01 & 2 & 0.00 & 37.4 & 2 & 0.2 & 5.86 & 2 & 0.03 \\
\hline $7 / 3 / 13$ & ON02 & 0.082 & 2 & 0.001 & 0.087 & 2 & 0.008 & 0.028 & 0.02 & 2 & 0.02 & 37.8 & 2 & 0.0 & 5.20 & 2 & 0.07 \\
\hline $7 / 3 / 13$ & ON03 & 0.055 & 2 & 0.007 & 0.046 & 2 & 0.008 & 0.038 & 0.01 & 2 & 0.00 & 37.3 & 2 & 0.1 & 5.20 & 2 & 0.06 \\
\hline $7 / 3 / 13$ & LC01 & 0.125 & 2 & 0.004 & 0.058 & 2 & 0.018 & 0.038 & 0.01 & 2 & 0.00 & 39.7 & 2 & 0.5 & 5.06 & 2 & 0.05 \\
\hline $7 / 3 / 13$ & $\mathrm{LC} 02$ & 0.045 & 2 & 0.001 & 0.029 & 2 & 0.005 & 0.023 & 0.01 & 2 & 0.00 & 37.6 & 2 & 0.2 & 4.94 & 2 & 0.01 \\
\hline $7 / 3 / 13$ & LC03 & 0.101 & 2 & 0.001 & 0.034 & 2 & 0.011 & 0.024 & 0.01 & 2 & 0.00 & 38.2 & 2 & 1.6 & 5.18 & 2 & 0.02 \\
\hline $7 / 3 / 13$ & OC01 & 0.075 & 2 & 0.005 & 0.048 & 2 & 0.004 & 0.041 & 0.02 & 2 & 0.01 & 38.4 & 2 & 0.3 & 4.98 & 2 & 0.01 \\
\hline $7 / 3 / 13$ & $\mathrm{OC} 02$ & 0.057 & 2 & 0.003 & 0.035 & 2 & 0.008 & 0.030 & 0.01 & 2 & 0.01 & 37.6 & 2 & 0.0 & 4.98 & 2 & 0.15 \\
\hline $7 / 3 / 13$ & $\mathrm{OC} 03$ & 0.062 & 2 & 0.004 & 0.021 & 2 & 0.021 & 0.019 & 0.01 & 2 & 0.00 & 37.7 & 2 & 0.3 & 4.84 & 2 & 0.05 \\
\hline $7 / 3 / 13$ & LS01 & 0.044 & 2 & 0.000 & 0.763 & 2 & 0.040 & 0.647 & 0.01 & 2 & 0.00 & 38.0 & 2 & 0.1 & 6.04 & 2 & 0.04 \\
\hline $7 / 3 / 13$ & LS02 & 0.055 & 2 & 0.010 & 0.969 & 2 & 0.174 & 0.660 & 0.01 & 2 & 0.00 & 38.9 & 2 & 0.4 & 6.88 & 2 & 0.01 \\
\hline $7 / 3 / 13$ & LS03 & 0.075 & 2 & 0.005 & 0.048 & 2 & 0.004 & 0.020 & 0.02 & 2 & 0.01 & 38.4 & 2 & 0.3 & 6.42 & 2 & 0.14 \\
\hline $7 / 3 / 13$ & OS01 & 0.078 & 2 & 0.001 & 0.433 & 2 & 0.046 & 0.280 & 0.01 & 2 & 0.00 & 39.7 & 2 & 0.1 & 5.93 & 2 & 0.21 \\
\hline $7 / 3 / 13$ & OS02 & 0.071 & 2 & 0.001 & 0.843 & 2 & 0.057 & 0.367 & 0.01 & 2 & 0.00 & 38.1 & 2 & 0.3 & 6.34 & 2 & 0.12 \\
\hline $7 / 3 / 13$ & OS03 & 0.103 & 2 & 0.018 & 0.530 & 2 & 0.228 & 0.410 & 0.01 & 2 & 0.00 & 39.7 & 2 & 0.1 & 5.53 & 2 & 0.01 \\
\hline $7 / 3 / 13$ & TR01 & 0.107 & 2 & 0.018 & 0.512 & 2 & 0.248 & 0.386 & 0.01 & 2 & 0.00 & 38.1 & 2 & 0.1 & 5.22 & 2 & 0.05 \\
\hline $7 / 3 / 13$ & TR01 & 0.085 & 2 & 0.002 & 0.216 & 2 & 0.015 & 0.139 & 0.02 & 2 & 0.00 & 39.4 & 2 & 0.5 & 5.37 & 2 & 0.08 \\
\hline $7 / 3 / 13$ & TR02 & 0.088 & 2 & 0.000 & 0.748 & 2 & 0.069 & 0.585 & 0.01 & 2 & 0.00 & 39.2 & 2 & 0.4 & 5.44 & 2 & 0.09 \\
\hline $7 / 3 / 13$ & TR02 & 0.090 & 2 & 0.001 & 0.299 & 2 & 0.013 & 0.155 & 0.02 & 2 & 0.00 & 39.2 & 2 & 0.1 & 5.31 & 2 & 0.01 \\
\hline $7 / 3 / 13$ & TR03 & 0.071 & 2 & 0.004 & 1.031 & 2 & 0.227 & 0.764 & 0.01 & 2 & 0.00 & 38.3 & 2 & 1.5 & 5.52 & 2 & 0.05 \\
\hline $7 / 3 / 13$ & TR03 & 0.092 & 2 & 0.003 & 0.265 & 2 & 0.017 & 0.108 & 0.01 & 2 & 0.00 & 38.2 & 2 & 1.1 & 5.38 & 2 & 0.01 \\
\hline
\end{tabular}


Table 6. 2013 dissolved (0.2-micrometer filtered) trace-element benthic fluxes from profiler deployments.

[Fe, iron; Mn, manganese; As, arsenic; V, vanadium; Co, cobalt; $\mathrm{Ni}$, nickel; $\mathrm{Cu}$, copper; $\mathrm{Zn}$, zinc; $\mathrm{Cd}$, cadmium; Pb, lead; $\mu \mathrm{g} \mathrm{m}^{-2} \mathrm{~d}^{-1}$, microgram per square meter per day; nd, nondetectable benthic flux due to concentrations from profiler samples that were consistently below detection limits for that solute; na, data not available from that time period; blank cells, values that are not available; S.D., standard deviation for the specified $\mathrm{n}$ replicates. Slightly darkened rows in the table are provided to help the reader distinguish results between sampling dates]

\begin{tabular}{|c|c|c|c|c|c|c|c|c|c|c|c|c|c|c|c|c|}
\hline \multirow[b]{2}{*}{ Date } & \multirow[b]{2}{*}{ Site } & \multicolumn{3}{|c|}{$\mu \mathrm{g} \mathrm{m}^{-2} \mathrm{~d}^{-1}$} & \multicolumn{3}{|c|}{$\mu^{M n ~ ~^{-2} d^{-1}}$} & \multicolumn{3}{|c|}{$\begin{array}{r}\text { As } \\
\mu g^{-2} d^{-1}\end{array}$} & \multicolumn{3}{|c|}{$\mu \mathrm{g} \mathrm{m}^{-2} \mathrm{~d}^{-1}$} & \multicolumn{3}{|c|}{$\begin{array}{l}\text { Co } \\
m^{-2} d^{-1}\end{array}$} \\
\hline & & Mean & $\mathrm{n}$ & S.D. & Mean & $\mathrm{n}$ & S.D. & Mean & $\mathrm{n}$ & S.D. & Mean & $\mathrm{n}$ & S.D. & Mean & $\mathrm{n}$ & S.D. \\
\hline $4 / 30 / 13$ & MDN_A & 4,875 & 2 & 61 & 823 & 2 & 117 & 33 & 2 & 7 & -27 & 2 & 21 & 0.67 & 2 & 0.09 \\
\hline $4 / 30 / 13$ & MDN_B & 7,560 & 2 & 694 & 1,074 & 2 & 12 & 33 & 2 & 15 & -32 & 2 & 8 & 0.51 & 2 & 0.24 \\
\hline $4 / 30 / 13$ & MDN C & 5,105 & 2 & 47 & 596 & 2 & 186 & 25 & 2 & 13 & -34 & 2 & 12 & 0.29 & 2 & 0.09 \\
\hline 4/30/13 & TRRecon & 6,479 & 2 & 1,064 & 1,227 & 2 & 30 & 131 & 2 & 34 & -54 & 2 & 16 & 0.82 & 2 & 0.03 \\
\hline $5 / 23 / 13$ & LN01 & 16,756 & 2 & 10,492 & 2,602 & 2 & 598 & 209 & 2 & 100 & -37 & 2 & 1 & 0.42 & 2 & 0.08 \\
\hline $5 / 23 / 13$ & LN02 & 5,734 & 2 & 407 & 1,711 & 2 & 727 & 44 & 2 & 35 & -42 & 2 & 16 & 0.49 & 2 & 0.61 \\
\hline $5 / 23 / 13$ & LN03 & 2,662 & 2 & 251 & 1,407 & 2 & 163 & 74 & 2 & 52 & -30 & 2 & 32 & 0.47 & 2 & 0.22 \\
\hline $5 / 23 / 13$ & ON01 & 9,982 & 2 & 785 & 915 & 2 & 226 & -14 & 2 & 12 & -23 & 2 & 5 & -0.07 & 2 & 1.15 \\
\hline $5 / 23 / 13$ & ON02 & 6,915 & 2 & 1,336 & 490 & 2 & 69 & -11 & 2 & 13 & -20 & 2 & 0 & -0.15 & 2 & 0.22 \\
\hline $5 / 23 / 13$ & ON03 & 4,233 & 2 & 1,843 & 598 & 2 & 312 & 5 & 2 & 12 & -45 & 2 & 6 & -0.05 & 2 & 0.02 \\
\hline $5 / 23 / 13$ & LC01 & 4,342 & 2 & 1,472 & 2,462 & 2 & 321 & 25 & 2 & 10 & -55 & 2 & 41 & 2.29 & 2 & 0.11 \\
\hline $5 / 23 / 13$ & LC02 & 53 & 2 & 4 & 1,419 & 2 & 742 & 11 & 2 & 6 & -15 & 2 & 4 & 1.84 & 2 & 0.14 \\
\hline $5 / 23 / 13$ & $\mathrm{LC} 03$ & 5,699 & 2 & 339 & 1,617 & 2 & 1,231 & 18 & 2 & 0 & -35 & 2 & 10 & 0.63 & 2 & 0.02 \\
\hline $5 / 23 / 13$ & OC01 & 4,710 & 2 & 3,042 & 1,271 & 2 & 103 & -4 & 2 & 20 & -18 & 2 & 22 & -0.02 & 2 & 0.47 \\
\hline $5 / 23 / 13$ & OC02 & 638 & 2 & 1,010 & 378 & 2 & 198 & 18 & 2 & 25 & -8 & 2 & 11 & -0.03 & 2 & 0.00 \\
\hline $5 / 23 / 13$ & $\mathrm{OC} 03$ & na & & & na & & & na & & & na & & & na & & \\
\hline $5 / 23 / 13$ & LS01 & 738 & 2 & 208 & 104 & 2 & 85 & -6 & 2 & 14 & -33 & 2 & 36 & 0.06 & 2 & 0.04 \\
\hline $5 / 23 / 13$ & LS02 & 2,584 & 2 & 1,630 & 143 & 2 & 194 & -5 & 2 & 1 & -14 & 2 & 0 & 0.05 & 2 & 0.10 \\
\hline $5 / 23 / 13$ & LS03 & 251 & 2 & 616 & 116 & 2 & 100 & -77 & 2 & 27 & -3 & 2 & 4 & -0.06 & 2 & 0.06 \\
\hline $5 / 23 / 13$ & OS01 & 4,892 & 2 & 193 & 606 & 2 & 167 & -4 & 2 & 2 & -30 & 2 & 7 & 0.16 & 2 & 0.07 \\
\hline $5 / 23 / 13$ & OS02 & 995 & 2 & 616 & 1,119 & 2 & 305 & -96 & 2 & 76 & -4 & 2 & 0 & 0.36 & 2 & 0.08 \\
\hline $5 / 23 / 13$ & OS03 & 11,188 & 2 & 7,580 & 951 & 2 & 675 & -12 & 2 & 6 & -19 & 2 & 23 & 0.49 & 2 & 0.25 \\
\hline $5 / 23 / 13$ & TR01 & 13,569 & 2 & 4,091 & 2,811 & 2 & 471 & 26 & 2 & 8 & -74 & 2 & 25 & 1.55 & 2 & 0.43 \\
\hline $5 / 23 / 13$ & TR02 & na & & & na & & & na & & & na & & & na & & \\
\hline $5 / 23 / 13$ & TR03 & 6,467 & 2 & 340 & 686 & 2 & 372 & 56 & 2 & 71 & -48 & 2 & 1 & 0.31 & 2 & 0.06 \\
\hline $6 / 13 / 13$ & LN01 & 1,784 & 2 & 1,397 & 506 & 2 & 47 & 58 & 2 & 15 & -45 & 2 & 34 & 0.20 & 2 & 0.12 \\
\hline $6 / 13 / 13$ & LN02 & 2,285 & 2 & 441 & 746 & 2 & 400 & 14 & 2 & 1 & -34 & 2 & 20 & 0.18 & 2 & 0.07 \\
\hline
\end{tabular}




\begin{tabular}{|c|c|c|c|c|c|c|c|c|c|c|c|c|c|c|c|c|}
\hline \multirow[b]{2}{*}{ Date } & \multirow[b]{2}{*}{ Site } & \multicolumn{3}{|c|}{$\begin{array}{r}F e \\
\mu g m^{-2} d^{-1}\end{array}$} & \multicolumn{3}{|c|}{$M n$} & \multicolumn{3}{|c|}{ As } & \multicolumn{3}{|c|}{$\begin{array}{r}V \\
m^{-2} d^{-1}\end{array}$} & \multicolumn{3}{|c|}{ Co } \\
\hline & & Mean & $\mathrm{n}$ & S.D. & Mean & $\mathrm{n}$ & S.D. & Mean & $\mathrm{n}$ & S.D. & Mean & $\mathrm{n}$ & S.D. & Mean & $\mathrm{n}$ & S.D. \\
\hline 6/13/13 & LN03 & 2,351 & 2 & 606 & 1,767 & 2 & 1,171 & 253 & 2 & 65 & -102 & 2 & 8 & 3.52 & 2 & 2.45 \\
\hline $6 / 13 / 13$ & ON01 & 1,782 & 2 & 1,286 & 598 & 2 & 244 & -19 & 2 & 2 & -33 & 2 & 29 & 0.14 & 2 & 0.08 \\
\hline $6 / 13 / 13$ & ON02 & 462 & 2 & 238 & 1,194 & 2 & 38 & 49 & 2 & 0 & -64 & 2 & 6 & 0.30 & 2 & 0.06 \\
\hline $6 / 13 / 13$ & ON03 & 1,302 & 2 & 567 & 441 & 2 & 192 & 74 & 2 & 80 & -13 & 2 & 9 & 0.21 & 2 & 0.08 \\
\hline $6 / 13 / 13$ & LC01 & 3,033 & 2 & 1,976 & 1,724 & 2 & 329 & 23 & 2 & 0 & -62 & 2 & 5 & 1.10 & 2 & 0.30 \\
\hline $6 / 13 / 13$ & $\mathrm{LC} 02$ & 20 & 2 & 9 & 1,801 & 2 & 142 & 28 & 2 & 3 & -25 & 2 & 27 & 2.97 & 2 & 0.18 \\
\hline $6 / 13 / 13$ & $\mathrm{LC} 03$ & 1,975 & 2 & 583 & 389 & 2 & 151 & 13 & 2 & 4 & -65 & 2 & 13 & 0.07 & 2 & 0.05 \\
\hline $6 / 13 / 13$ & OC01 & 2,810 & 2 & 783 & 976 & 2 & 261 & 5 & 2 & 14 & -72 & 2 & 56 & 0.14 & 2 & 0.00 \\
\hline $6 / 13 / 13$ & $\mathrm{OC} 02$ & 5,176 & 2 & 3,441 & 2,636 & 2 & 536 & 53 & 2 & 18 & -64 & 2 & 49 & 0.43 & 2 & 0.21 \\
\hline $6 / 13 / 13$ & $\mathrm{OC} 03$ & 5,540 & 2 & 3,478 & 1,511 & 2 & 345 & 45 & 2 & 25 & -39 & 2 & 34 & 0.19 & 2 & 0.07 \\
\hline $6 / 13 / 13$ & LS01 & 563 & 2 & 347 & 97 & 2 & 23 & -26 & 2 & 1 & -79 & 2 & 17 & -0.04 & 2 & 0.02 \\
\hline $6 / 13 / 13$ & LS02 & 277 & 2 & 43 & 63 & 2 & 69 & -117 & 2 & 2 & -70 & 2 & 19 & -0.02 & 2 & 0.03 \\
\hline $6 / 13 / 13$ & LS03 & 240 & 2 & 219 & 41 & 2 & 25 & -54 & 2 & 4 & -98 & 2 & 121 & 0.07 & 2 & 0.02 \\
\hline $6 / 13 / 13$ & OS01 & 792 & 2 & 187 & 598 & 2 & 215 & -11 & 2 & 10 & -101 & 2 & 8 & 0.12 & 2 & 0.03 \\
\hline $6 / 13 / 13$ & OS02 & 3,350 & 2 & 139 & 1,390 & 2 & 640 & -2 & 2 & 7 & -63 & 2 & 3 & 0.00 & 2 & 0.12 \\
\hline $6 / 13 / 13$ & OS03 & 3,447 & 2 & 25 & 263 & 2 & 226 & -47 & 2 & 34 & -13 & 2 & 6 & 0.54 & 2 & 0.04 \\
\hline $6 / 13 / 13$ & TR01 & 3,398 & 2 & 479 & 1,058 & 2 & 495 & 4 & 2 & 7 & -48 & 2 & 13 & 0.03 & 2 & 0.04 \\
\hline $6 / 13 / 13$ & TR02 & 1,539 & 2 & 834 & 1,603 & 2 & 172 & 121 & 2 & 26 & -62 & 2 & 2 & 0.34 & 2 & 0.31 \\
\hline $6 / 13 / 13$ & TR03 & 4,314 & 2 & 2,571 & 2,730 & 2 & 517 & 82 & 2 & 65 & -71 & 2 & 8 & 0.39 & 2 & 0.28 \\
\hline $7 / 3 / 13$ & LN01 & 1,351 & 2 & 253 & 341 & 2 & 215 & 39 & 2 & 1 & -70 & 2 & 37 & 0.00 & 2 & 0.09 \\
\hline $7 / 3 / 13$ & LN02 & 1,295 & 2 & 715 & 454 & 2 & 9 & -9 & 2 & 4 & -99 & 2 & 68 & 0.03 & 2 & 0.03 \\
\hline $7 / 3 / 13$ & LN03 & 7,760 & 2 & 1,919 & 2,011 & 2 & 517 & 123 & 2 & 82 & -79 & 2 & 74 & 1.26 & 2 & 0.05 \\
\hline $7 / 3 / 13$ & ON01 & 2,203 & 2 & 1,298 & 430 & 2 & 327 & -22 & 2 & 18 & -34 & 2 & 39 & 0.10 & 2 & 0.02 \\
\hline $7 / 3 / 13$ & ON02 & 1,982 & 2 & 978 & 539 & 2 & 299 & -5 & 2 & 2 & -23 & 2 & 29 & 0.07 & 2 & 0.07 \\
\hline $7 / 3 / 13$ & ON03 & 929 & 2 & 277 & 367 & 2 & 33 & -2 & 2 & 7 & -72 & 2 & 25 & -0.09 & 2 & 0.02 \\
\hline $7 / 3 / 13$ & $\mathrm{LC} 01$ & 4,879 & 2 & 3,757 & 1,327 & 2 & 118 & 4 & 2 & 8 & -39 & 2 & 40 & 0.22 & 2 & 0.30 \\
\hline $7 / 3 / 13$ & $\mathrm{LC} 02$ & 908 & 2 & 143 & 5,455 & 2 & 1,211 & 53 & 2 & 23 & -37 & 2 & 24 & 4.40 & 2 & 0.21 \\
\hline $7 / 3 / 13$ & $\mathrm{LC} 03$ & 6,652 & 2 & 2,681 & 1,897 & 2 & 474 & -15 & 2 & 10 & -106 & 2 & 5 & 0.90 & 2 & 0.45 \\
\hline $7 / 3 / 13$ & OC01 & 866 & 2 & 371 & 996 & 2 & 136 & 0 & 2 & 3 & -119 & 2 & 5 & -0.27 & 2 & 0.03 \\
\hline $7 / 3 / 13$ & $\mathrm{OC} 02$ & 3,456 & 2 & 424 & 1,329 & 2 & 71 & 4 & 2 & 2 & -179 & 2 & 98 & 0.10 & 2 & 0.18 \\
\hline $7 / 3 / 13$ & $\mathrm{OC} 03$ & 2,188 & 2 & 848 & 1,059 & 2 & 198 & 51 & 2 & 11 & -142 & 2 & 39 & -0.10 & 2 & 0.09 \\
\hline $7 / 3 / 13$ & LS01 & 287 & 2 & 164 & 187 & 2 & 68 & -14 & 2 & 7 & -12 & 2 & 15 & 0.00 & 2 & 0.04 \\
\hline
\end{tabular}




\begin{tabular}{|c|c|c|c|c|c|c|c|c|c|c|c|c|c|c|c|c|}
\hline \multirow[b]{2}{*}{ Date } & \multirow[b]{2}{*}{ Site } & \multicolumn{3}{|c|}{$\begin{array}{r}F e \\
\mu g^{-2} d^{-1}\end{array}$} & \multicolumn{3}{|c|}{$\mu \mathrm{g} \mathrm{m}^{-2} \mathrm{~d}^{-1}$} & \multicolumn{3}{|c|}{$\begin{array}{r}\text { As } \\
\mu \mathrm{g} \mathrm{m}^{-2} \mathrm{~d}^{-1}\end{array}$} & \multicolumn{3}{|c|}{$\begin{array}{r}V \\
\mu g^{-2} d^{-1}\end{array}$} & \multicolumn{3}{|c|}{$\begin{array}{r}\text { Co } \\
\mu g^{-2} d^{-1}\end{array}$} \\
\hline & & Mean & $\mathrm{n}$ & S.D. & Mean & $\mathrm{n}$ & S.D. & Mean & $\mathrm{n}$ & S.D. & Mean & $\mathrm{n}$ & S.D. & Mean & $\mathrm{n}$ & S.D. \\
\hline $7 / 3 / 13$ & LS02 & 179 & 2 & 20 & 23 & 2 & 8 & -76 & 2 & 16 & -28 & 2 & 20 & 0.04 & 2 & 0.01 \\
\hline $7 / 3 / 13$ & LS03 & 135 & 2 & 26 & 193 & 2 & 107 & -12 & 2 & 1 & -6 & 2 & 3 & 0.03 & 2 & 0.10 \\
\hline $7 / 3 / 13$ & OS01 & 1,410 & 2 & 1,189 & 867 & 2 & 471 & -16 & 2 & 16 & -69 & 2 & 76 & -0.04 & 2 & 0.05 \\
\hline $7 / 3 / 13$ & OS02 & 165 & 2 & 82 & 155 & 2 & 12 & -14 & 2 & 3 & -101 & 2 & 23 & -0.09 & 2 & 0.06 \\
\hline $7 / 3 / 13$ & OS03 & 3,101 & 2 & 691 & 773 & 2 & 110 & -32 & 2 & 1 & -27 & 2 & 32 & 0.33 & 2 & 0.05 \\
\hline $7 / 3 / 13$ & TR01 & 5,651 & 2 & 879 & 1,219 & 2 & 24 & 68 & 2 & 1 & -95 & 2 & 2 & 0.00 & 2 & 0.00 \\
\hline $7 / 3 / 13$ & TR02 & 2,433 & 2 & 554 & 149 & 2 & 135 & -11 & 2 & 4 & -98 & 2 & 34 & -0.08 & 2 & 0.01 \\
\hline $7 / 3 / 13$ & TR03 & 3,953 & 2 & 502 & 1,241 & 2 & 267 & 53 & 2 & 10 & -81 & 2 & 8 & 0.12 & 2 & 0.06 \\
\hline
\end{tabular}




\begin{tabular}{|c|c|c|c|c|c|c|c|c|c|c|c|c|c|c|c|c|}
\hline \multirow[b]{2}{*}{ Date } & \multirow[b]{2}{*}{ Site } & \multicolumn{3}{|c|}{$\mu \mathrm{g} \mathrm{m}^{-2} \mathrm{~d}^{-1}$} & \multicolumn{3}{|c|}{$\mu \mathrm{g} \mathrm{m}^{-2} \mathrm{~d}^{-1} \mathrm{Cu}$} & \multicolumn{3}{|c|}{$\mu \mathrm{g} \mathrm{m}^{-2} \mathrm{~d}^{-1} \mathrm{Zn}$} & \multicolumn{3}{|c|}{$\mathrm{Cd}$} & \multicolumn{3}{|c|}{$\mathrm{Pb}$} \\
\hline & & Mean & $\mathrm{n}$ & S.D. & Mean & $\mathrm{n}$ & S.D. & Mean & $\mathrm{n}$ & S.D. & Mean & $\mathrm{n}$ & S.D. & Mean & $\mathrm{n}$ & S.D. \\
\hline $4 / 30 / 13$ & MDN_A & -0.45 & 2 & 0.23 & -1.24 & 2 & 0.50 & 0.21 & 2 & 1.13 & 0.00 & 2 & 0.00 & -0.02 & 2 & 0.05 \\
\hline $4 / 30 / 13$ & MDN_B & -0.44 & 2 & 0.43 & -0.77 & 2 & 0.09 & 0.23 & 2 & 0.52 & 0.00 & 2 & 0.00 & -0.02 & 2 & 0.03 \\
\hline $4 / 30 / 13$ & MDN_C & -0.56 & 2 & 1.10 & -12.50 & 2 & 15.67 & -0.02 & 2 & 0.13 & 0.00 & 2 & 0.00 & 0.01 & 2 & 0.02 \\
\hline 4/30/13 & TRRecon & 2.14 & 2 & 0.44 & -1.85 & 2 & 1.47 & 4.15 & 2 & 2.46 & 0.00 & 2 & 0.00 & -0.01 & 2 & 0.03 \\
\hline $5 / 23 / 13$ & LN01 & 0.85 & 2 & 0.26 & -1.56 & 2 & 0.45 & -4.08 & 2 & 1.38 & 0.01 & 2 & 0.00 & -1.02 & 2 & 0.04 \\
\hline $5 / 23 / 13$ & LN02 & 1.09 & 2 & 1.27 & -3.90 & 2 & 2.15 & -3.40 & 2 & 0.98 & 0.01 & 2 & 0.00 & -0.51 & 2 & 0.66 \\
\hline $5 / 23 / 13$ & LN03 & 0.94 & 2 & 0.80 & -0.63 & 2 & 0.02 & -1.81 & 2 & 0.16 & 0.01 & 2 & 0.00 & 0.01 & 2 & 0.10 \\
\hline $5 / 23 / 13$ & ON01 & -0.28 & 2 & 0.41 & -0.79 & 2 & 0.40 & -0.74 & 2 & 0.44 & 0.01 & 2 & 0.00 & -0.13 & 2 & 0.18 \\
\hline $5 / 23 / 13$ & ON02 & -0.15 & 2 & 0.24 & -1.13 & 2 & 0.45 & -0.97 & 2 & 1.36 & 0.01 & 2 & 0.00 & 0.00 & 2 & 0.03 \\
\hline $5 / 23 / 13$ & ON03 & 0.22 & 2 & 0.38 & -1.69 & 2 & 0.19 & 0.00 & 2 & 0.00 & 0.01 & 2 & 0.00 & 0.00 & 2 & 0.00 \\
\hline $5 / 23 / 13$ & LC01 & 2.16 & 2 & 1.19 & -1.53 & 2 & 0.51 & 3.75 & 2 & 0.89 & 0.01 & 2 & 0.00 & -0.05 & 2 & 0.09 \\
\hline $5 / 23 / 13$ & $\mathrm{LC} 02$ & 2.91 & 2 & 0.01 & -0.35 & 2 & 0.11 & 4.27 & 2 & 0.68 & 0.01 & 2 & 0.00 & 0.11 & 2 & 0.02 \\
\hline $5 / 23 / 13$ & LC03 & 1.18 & 2 & 0.50 & -1.00 & 2 & 0.06 & 3.39 & 2 & 0.00 & 0.01 & 2 & 0.00 & 0.04 & 2 & 0.00 \\
\hline $5 / 23 / 13$ & OC01 & 0.16 & 2 & 0.60 & -1.72 & 2 & 0.71 & 0.00 & 2 & 0.00 & 0.01 & 2 & 0.00 & 0.00 & 2 & 0.03 \\
\hline $5 / 23 / 13$ & $\mathrm{OC} 02$ & 0.16 & 2 & 0.19 & -0.51 & 2 & 0.73 & -1.26 & 2 & 1.78 & 0.01 & 2 & 0.00 & 0.09 & 2 & 0.12 \\
\hline $5 / 23 / 13$ & $\mathrm{OC} 03$ & na & & & na & & & na & & & na & & & na & & na \\
\hline $5 / 23 / 13$ & LS01 & 0.97 & 2 & 2.53 & -1.10 & 2 & 1.16 & -6.62 & 2 & 7.17 & 0.01 & 2 & 0.00 & -0.08 & 2 & 0.13 \\
\hline $5 / 23 / 13$ & LS02 & -0.63 & 2 & 0.36 & -0.49 & 2 & 0.25 & -3.74 & 2 & 5.29 & 0.01 & 1 & & -0.01 & 1 & \\
\hline $5 / 23 / 13$ & LS03 & -1.15 & 2 & 0.67 & -0.55 & 2 & 0.14 & 0.00 & 2 & 0.00 & 0.01 & 1 & & 0.01 & 2 & 0.04 \\
\hline $5 / 23 / 13$ & OS01 & 0.60 & 2 & 0.97 & -1.40 & 2 & 0.63 & -24.93 & 2 & 10.14 & 0.01 & 2 & 0.00 & 0.03 & 2 & 0.04 \\
\hline $5 / 23 / 13$ & OS02 & 0.68 & 2 & 0.41 & -0.34 & 2 & 0.30 & -2.69 & 2 & 0.49 & 0.01 & 2 & 0.00 & 0.00 & 2 & 0.04 \\
\hline $5 / 23 / 13$ & OS03 & 0.39 & 2 & 0.05 & -0.94 & 2 & 0.88 & -1.08 & 2 & 1.52 & 0.01 & 2 & 0.00 & 0.00 & 2 & 0.00 \\
\hline $5 / 23 / 13$ & TR01 & 0.45 & 2 & 0.10 & -1.97 & 2 & 0.09 & 1.68 & 2 & 1.72 & 0.01 & 2 & 0.00 & 0.02 & 2 & 0.00 \\
\hline $5 / 23 / 13$ & TR02 & na & & & na & & & na & & & na & & & na & & na \\
\hline $5 / 23 / 13$ & TR03 & 0.58 & 2 & 0.10 & -2.26 & 2 & 0.99 & 5.92 & 2 & 3.64 & 0.01 & 2 & 0.00 & 0.00 & 2 & 0.01 \\
\hline $6 / 13 / 13$ & LN01 & 0.25 & 2 & 0.06 & -0.56 & 2 & 0.24 & nd & 2 & & 0.00 & 2 & 0.00 & 0.01 & 2 & 0.03 \\
\hline $6 / 13 / 13$ & LN02 & -0.36 & 2 & 0.55 & -0.41 & 2 & 0.08 & nd & 2 & & 0.00 & 2 & 0.00 & -0.01 & 2 & 0.01 \\
\hline $6 / 13 / 13$ & LN03 & 2.07 & 2 & 0.71 & -3.50 & 2 & 0.29 & nd & 2 & & 0.00 & 2 & 0.00 & 0.01 & 2 & 0.02 \\
\hline $6 / 13 / 13$ & ON01 & 0.32 & 2 & 0.09 & -0.51 & 2 & 0.66 & nd & 2 & & 0.00 & 2 & 0.00 & 0.00 & 2 & 0.01 \\
\hline $6 / 13 / 13$ & ON02 & 0.46 & 2 & 0.33 & -1.09 & 2 & 0.42 & nd & 2 & & 0.00 & 2 & 0.00 & 0.01 & 2 & 0.01 \\
\hline $6 / 13 / 13$ & ON03 & 0.17 & 2 & 0.02 & -0.17 & 2 & 0.04 & nd & 2 & & 0.00 & 2 & 0.00 & 0.00 & 2 & 0.00 \\
\hline
\end{tabular}




\begin{tabular}{|c|c|c|c|c|c|c|c|c|c|c|c|c|c|c|c|c|}
\hline \multirow[b]{2}{*}{ Date } & \multirow[b]{2}{*}{ Site } & \multicolumn{3}{|c|}{$\mu \mathrm{g} \mathrm{m}^{-2} \mathrm{~d}^{-1}$} & \multicolumn{3}{|c|}{$d^{-1}$} & \multicolumn{3}{|c|}{$\mu \mathrm{g} \mathrm{m}^{-2} \mathrm{~d}^{-1} \mathrm{Zn}$} & \multicolumn{3}{|c|}{$\mu g^{C d} m^{-2} d^{-1}$} & \multicolumn{3}{|c|}{$\mathrm{Pb}$} \\
\hline & & Mean & $\mathrm{n}$ & S.D. & Mean & $\mathrm{n}$ & S.D. & Mean & $\mathrm{n}$ & S.D. & Mean & $\mathrm{n}$ & S.D. & Mean & $\mathrm{n}$ & S.D. \\
\hline $6 / 13 / 13$ & LC01 & 1.24 & 2 & 0.59 & -1.53 & 2 & 0.24 & nd & 2 & & 0.00 & 2 & 0.00 & -0.01 & 2 & 0.00 \\
\hline $6 / 13 / 13$ & LC02 & 2.39 & 2 & 0.23 & -0.33 & 2 & 0.13 & nd & 2 & & 0.00 & 2 & 0.00 & 0.00 & 2 & 0.00 \\
\hline $6 / 13 / 13$ & LC03 & 0.28 & 2 & 0.02 & -0.64 & 2 & 0.22 & nd & 2 & & 0.00 & 2 & 0.00 & 0.01 & 2 & 0.01 \\
\hline $6 / 13 / 13$ & OC01 & 0.13 & 2 & 0.03 & -0.49 & 2 & 0.16 & nd & 2 & & 0.00 & 2 & 0.00 & -0.03 & 2 & 0.06 \\
\hline $6 / 13 / 13$ & OC02 & 0.67 & 2 & 0.13 & -0.64 & 2 & 0.10 & nd & 2 & & 0.00 & 2 & 0.00 & 0.00 & 2 & 0.00 \\
\hline $6 / 13 / 13$ & OC03 & 0.43 & 2 & 0.18 & -0.39 & 2 & 0.22 & nd & 2 & & 0.00 & 2 & 0.00 & 0.00 & 2 & 0.00 \\
\hline $6 / 13 / 13$ & LS01 & 0.16 & 2 & 0.00 & -0.67 & 2 & 0.19 & nd & 2 & & 0.00 & 2 & 0.00 & 0.00 & 2 & 0.00 \\
\hline $6 / 13 / 13$ & LS02 & 0.13 & 2 & 0.03 & -0.96 & 2 & 0.80 & nd & 2 & & 0.00 & 2 & 0.00 & 0.00 & 2 & 0.00 \\
\hline $6 / 13 / 13$ & LS03 & -0.16 & 2 & 0.09 & -1.04 & 2 & 0.09 & nd & 2 & & 0.00 & 2 & 0.00 & -0.02 & 2 & 0.03 \\
\hline $6 / 13 / 13$ & OS01 & -0.14 & 2 & 0.05 & -2.49 & 2 & 1.89 & nd & 2 & & 0.00 & 2 & 0.00 & 0.01 & 2 & 0.01 \\
\hline $6 / 13 / 13$ & OS02 & 0.44 & 2 & 0.08 & -3.73 & 2 & 2.40 & nd & 2 & & 0.00 & 2 & 0.00 & 0.00 & 2 & 0.01 \\
\hline $6 / 13 / 13$ & OS03 & 0.10 & 2 & 0.14 & -0.20 & 2 & 0.02 & nd & 2 & & 0.00 & 2 & 0.00 & 0.00 & 2 & 0.01 \\
\hline $6 / 13 / 13$ & TR01 & 0.12 & 2 & 0.25 & -0.49 & 2 & 0.02 & nd & 2 & & 0.00 & 2 & 0.00 & 0.00 & 2 & 0.00 \\
\hline $6 / 13 / 13$ & TR02 & 0.58 & 2 & 0.03 & -0.79 & 2 & 0.31 & nd & 2 & & 0.00 & 2 & 0.00 & 0.01 & 2 & 0.01 \\
\hline $6 / 13 / 13$ & TR03 & 0.77 & 2 & 0.57 & -1.10 & 2 & 0.46 & nd & 2 & & 0.00 & 2 & 0.00 & 0.00 & 2 & 0.00 \\
\hline $7 / 3 / 13$ & LN01 & -0.09 & 2 & 0.12 & -5.45 & 2 & 3.89 & -29.12 & 2 & 40.63 & -0.02 & 2 & 0.01 & -0.28 & 2 & 0.00 \\
\hline $7 / 3 / 13$ & LN02 & 0.06 & 2 & 0.23 & -1.77 & 2 & 0.26 & 3.71 & 2 & 5.48 & 0.00 & 2 & 0.00 & -0.07 & 2 & 0.04 \\
\hline $7 / 3 / 13$ & LN03 & 3.36 & 2 & 1.96 & -1.52 & 2 & 0.66 & 15.41 & 2 & 13.20 & 0.03 & 2 & 0.04 & 0.01 & 2 & 0.06 \\
\hline $7 / 3 / 13$ & ON01 & 0.40 & 2 & 0.31 & -4.00 & 2 & 0.45 & -6.82 & 2 & 8.94 & -0.01 & 2 & 0.02 & -0.21 & 2 & 0.25 \\
\hline $7 / 3 / 13$ & ON02 & -1.01 & 2 & 0.72 & -7.65 & 2 & 7.21 & -20.47 & 2 & 10.76 & -0.01 & 2 & 0.01 & 0.27 & 2 & 0.08 \\
\hline $7 / 3 / 13$ & ON03 & -1.32 & 2 & 1.78 & -7.94 & 2 & 5.72 & -22.53 & 2 & 19.16 & -0.01 & 2 & 0.02 & -0.28 & 2 & 0.32 \\
\hline $7 / 3 / 13$ & LC01 & 0.43 & 2 & 0.03 & -1.69 & 2 & 1.65 & -1.10 & 2 & 0.93 & 0.00 & 2 & 0.00 & 0.02 & 2 & 0.09 \\
\hline $7 / 3 / 13$ & LC02 & 3.35 & 2 & 2.13 & -3.03 & 2 & 0.46 & 5.52 & 2 & 2.20 & 0.01 & 2 & 0.01 & 0.10 & 2 & 0.06 \\
\hline $7 / 3 / 13$ & LC03 & 1.41 & 2 & 0.68 & -3.25 & 2 & 0.02 & -1.87 & 1 & & 0.00 & 2 & 0.00 & 0.23 & 2 & 0.08 \\
\hline $7 / 3 / 13$ & OC01 & -0.20 & 2 & 0.15 & -3.62 & 2 & 1.26 & 5.10 & 1 & & 0.00 & 2 & 0.00 & 0.03 & 2 & 0.02 \\
\hline $7 / 3 / 13$ & $\mathrm{OC} 02$ & -2.15 & 2 & 1.85 & -28.13 & 2 & 36.65 & 7.34 & 2 & 9.55 & 0.01 & 2 & 0.02 & 0.09 & 2 & 0.19 \\
\hline $7 / 3 / 13$ & OC03 & 0.41 & 2 & 0.76 & -4.35 & 2 & 4.51 & -2.61 & 2 & 1.01 & 0.00 & 2 & 0.00 & -0.03 & 2 & 0.21 \\
\hline $7 / 3 / 13$ & LS01 & -1.15 & 2 & 1.03 & -0.87 & 2 & 0.09 & 0.94 & 1 & & 0.00 & 2 & 0.00 & 0.02 & 2 & 0.01 \\
\hline $7 / 3 / 13$ & LS02 & -0.23 & 2 & 0.07 & -0.47 & 2 & 0.08 & 2.06 & 1 & & 0.00 & 2 & 0.00 & -0.01 & 2 & 0.01 \\
\hline $7 / 3 / 13$ & LS03 & 0.41 & 2 & 0.47 & -1.12 & 2 & 0.43 & -3.61 & 2 & 1.46 & 0.00 & 2 & 0.00 & 0.02 & 2 & 0.17 \\
\hline $7 / 3 / 13$ & OS01 & 0.37 & 2 & 0.02 & -2.92 & 2 & 0.53 & -1.13 & 2 & 0.87 & 0.00 & 2 & 0.00 & 0.93 & 2 & 1.16 \\
\hline $7 / 3 / 13$ & OS02 & -0.37 & 2 & 0.53 & -1.02 & 2 & 0.10 & nd & 2 & & 0.00 & 2 & 0.00 & -0.05 & 2 & 0.02 \\
\hline
\end{tabular}




\begin{tabular}{|c|c|c|c|c|c|c|c|c|c|c|c|c|c|c|c|c|}
\hline \multirow[b]{2}{*}{ Date } & \multirow[b]{2}{*}{ Site } & \multicolumn{3}{|c|}{$\mu \mathrm{g} \mathrm{m}^{-2} \mathrm{~d}^{-1}$} & \multicolumn{3}{|c|}{$\mu \mathrm{g} \mathrm{m}^{-2} \mathrm{~d}^{-1}$} & \multicolumn{3}{|c|}{$\mu \mathrm{g} \mathrm{m}^{-2} \mathrm{~d}^{-1}$} & \multicolumn{3}{|c|}{$\mu \mathrm{g} \mathrm{m}^{-2} \mathrm{~d}$} & \multicolumn{3}{|c|}{$\mathrm{Pb}$} \\
\hline & & Mean & $\mathrm{n}$ & S.D. & Mean & $\mathrm{n}$ & S.D. & Mean & $\mathrm{n}$ & S.D. & Mean & $n$ & S.D. & Mean & $\mathrm{n}$ & S.D. \\
\hline $7 / 3 / 13$ & OS03 & 0.29 & 2 & 0.10 & -1.08 & 2 & 1.44 & nd & 2 & & -0.15 & 2 & 0.21 & -0.15 & 2 & 0.11 \\
\hline $7 / 3 / 13$ & TR01 & 0.62 & 2 & 1.09 & -1.68 & 2 & 0.55 & 3.33 & 2 & 1.89 & 0.00 & 2 & 0.00 & -0.07 & 2 & 0.01 \\
\hline $7 / 3 / 13$ & TR02 & 0.17 & 2 & 0.09 & -0.72 & 2 & 0.91 & 10.93 & 2 & 4.95 & 0.00 & 2 & 0.00 & -0.02 & 2 & 0.18 \\
\hline $7 / 3 / 13$ & TR03 & 1.13 & 2 & 0.14 & -1.09 & 2 & 0.61 & 1.66 & 2 & 1.04 & 0.00 & 2 & 0.00 & -0.06 & 2 & 0.02 \\
\hline
\end{tabular}


Table 7. 2013 dissolved (0.2-micrometer filtered) trace-element concentrations in the water column Upper Klamath Lake, Oregon.

[Fe, iron; Mn, manganese; As, arsenic; V, vanadium; Co, cobalt; Ni, nickel; $\mathrm{Cu}$, copper; $\mathrm{Zn}$, zinc; $\mathrm{Cd}$, cadmium; $\mathrm{Pb}$, lead; $\mu \mathrm{g} \mathrm{L}^{-1}$, microgram per liter; blank cells, values that are not available; S.D., standard deviation for the specified $\mathrm{n}$ replicates. Slightly darkened rows in the table for June 13, 2013, are provided to help the reader distinguish results between sampling dates]

\begin{tabular}{|c|c|c|c|c|c|c|c|c|c|c|c|c|c|c|c|c|c|}
\hline \multirow[b]{3}{*}{ Date } & \multirow[b]{3}{*}{ Site } & \multicolumn{4}{|c|}{$\mathrm{Fe}$} & \multicolumn{3}{|c|}{$\mathrm{Mn}$} & \multicolumn{3}{|c|}{ As } & \multicolumn{3}{|c|}{ V } & \multicolumn{3}{|c|}{ Co } \\
\hline & & & $\mu \mathrm{g} \mathrm{L}^{-1}$ & & & $\mu g L^{-1}$ & & & $\mu \mathrm{g} \mathrm{L}^{-1}$ & & & $\mu g L^{-1}$ & & & $\mu g L^{-1}$ & & \\
\hline & & Depth & Mean & $\mathrm{n}$ & S.D. & Mean & $\mathrm{n}$ & S.D. & Mean & $\mathrm{n}$ & S.D. & Mean & $\mathrm{n}$ & S.D. & Mean & $\mathrm{n}$ & S.D. \\
\hline 4/30/13 & $\mathrm{MDN}$ & surface & 29.3 & 2 & 0.1 & 1.19 & 2 & 0.29 & 3.72 & 2 & 0.24 & 10.74 & 2 & 0.15 & 0.086 & 2 & 0.011 \\
\hline $4 / 30 / 13$ & Recon TR & surface & 16.8 & 2 & 0.1 & 0.96 & 2 & 0.48 & 3.62 & 2 & 0.03 & 9.69 & 2 & 0.00 & 0.031 & 2 & 0.006 \\
\hline $4 / 30 / 13$ & Recon TR & bottom & 28.8 & 2 & 15.4 & 1.60 & 2 & 0.32 & 3.65 & 2 & 0.03 & 9.65 & 2 & 0.14 & 0.035 & 2 & 0.004 \\
\hline $5 / 23 / 13$ & LC01 & surface & 15.3 & 2 & 0.5 & 7.27 & 2 & 7.08 & 8.05 & 2 & 0.42 & 11.01 & 2 & 0.08 & 0.045 & 2 & 0.013 \\
\hline $5 / 23 / 13$ & $\mathrm{LC} 02$ & surface & 22.6 & 2 & 7.2 & 0.86 & 2 & 0.33 & 6.75 & 2 & 0.01 & 11.06 & 2 & 0.10 & 0.033 & 2 & 0.002 \\
\hline $5 / 23 / 13$ & $\mathrm{LC} 03$ & surface & 15.9 & 2 & 1.2 & 2.47 & 2 & 0.43 & 4.84 & 2 & 0.29 & 13.60 & 2 & 0.19 & 0.053 & 2 & 0.015 \\
\hline $5 / 23 / 13$ & LN01 & surface & 13.4 & 2 & 0.1 & 3.53 & 2 & 0.24 & 10.35 & 2 & 0.20 & 7.55 & 2 & 0.12 & 0.035 & 2 & 0.000 \\
\hline $5 / 23 / 13$ & LN02 & surface & 7.9 & 2 & 0.3 & 0.80 & 2 & 0.14 & 4.97 & 2 & 0.15 & 8.18 & 2 & 0.29 & 0.038 & 2 & 0.001 \\
\hline $5 / 23 / 13$ & LN03 & surface & 7.6 & 2 & 0.3 & 0.61 & 2 & 0.04 & 4.85 & 2 & 0.04 & 8.58 & 2 & 0.15 & 0.038 & 2 & 0.000 \\
\hline $5 / 23 / 13$ & LS01 & surface & 9.7 & 2 & 3.5 & 0.31 & 2 & 0.16 & 6.21 & 2 & 0.15 & 9.09 & 2 & 0.04 & 0.026 & 2 & 0.000 \\
\hline $5 / 23 / 13$ & LS02 & surface & 7.4 & 2 & 0.9 & 0.27 & 2 & 0.02 & 6.22 & 2 & 0.03 & 9.00 & 2 & 0.03 & 0.025 & 2 & 0.002 \\
\hline $5 / 23 / 13$ & LS03 & surface & 6.7 & 2 & 0.4 & 0.34 & 2 & 0.02 & 6.48 & 2 & 0.00 & 9.47 & 2 & 0.07 & 0.029 & 2 & 0.002 \\
\hline $5 / 23 / 13$ & OC01 & surface & 6.5 & 2 & 1.0 & 0.57 & 2 & 0.14 & 5.06 & 2 & 0.00 & 7.97 & 2 & 0.03 & 0.028 & 2 & 0.005 \\
\hline $5 / 23 / 13$ & $\mathrm{OC} 02$ & surface & 15.2 & 2 & 1.0 & 1.36 & 2 & 0.09 & 8.09 & 2 & 0.16 & 11.92 & 2 & 0.20 & 0.053 & 2 & 0.000 \\
\hline $5 / 23 / 13$ & OC03 & surface & 27.7 & 2 & 19.6 & 1.85 & 2 & 1.92 & 6.00 & 2 & 0.10 & 11.19 & 2 & 0.11 & 0.042 & 2 & 0.005 \\
\hline $5 / 23 / 13$ & ON01 & surface & 14.5 & 2 & 2.1 & 1.24 & 2 & 0.06 & 4.80 & 2 & 0.04 & 8.34 & 2 & 0.13 & 0.032 & 2 & 0.000 \\
\hline $5 / 23 / 13$ & ON02 & surface & 6.7 & 2 & 0.8 & 0.55 & 2 & 0.04 & 4.82 & 2 & 0.01 & 7.80 & 2 & 0.00 & 0.030 & 2 & 0.001 \\
\hline $5 / 23 / 13$ & ON03 & surface & 7.8 & 2 & 0.0 & 0.69 & 2 & 0.00 & 4.76 & 2 & 0.03 & 7.73 & 2 & 0.07 & 0.032 & 2 & 0.001 \\
\hline $5 / 23 / 13$ & OS01 & surface & 5.5 & 2 & 0.2 & 0.25 & 2 & 0.17 & 4.91 & 2 & 0.03 & 7.68 & 2 & 0.03 & 0.022 & 2 & 0.002 \\
\hline $5 / 23 / 13$ & OS02 & surface & 6.2 & 2 & 0.5 & 0.32 & 2 & 0.18 & 4.95 & 2 & 0.01 & 7.76 & 2 & 0.10 & 0.024 & 2 & 0.002 \\
\hline $5 / 23 / 13$ & OS03 & surface & 6.7 & 2 & 0.6 & 0.31 & 2 & 0.10 & 4.83 & 2 & 0.04 & 7.66 & 2 & 0.27 & 0.025 & 2 & 0.008 \\
\hline $5 / 23 / 13$ & TR01 & surface & 5.4 & 2 & 0.5 & 0.14 & 2 & 0.01 & 5.13 & 2 & 0.04 & 7.86 & 2 & 0.06 & 0.022 & 2 & 0.001 \\
\hline $5 / 23 / 13$ & TR01 & bottom & 6.9 & 2 & 0.7 & 0.20 & 2 & 0.03 & 5.56 & 2 & 0.05 & 7.98 & 2 & 0.15 & 0.023 & 2 & 0.001 \\
\hline $5 / 23 / 13$ & TR02 & surface & 5.8 & 2 & 0.3 & 0.23 & 2 & 0.10 & 4.99 & 2 & 0.17 & 7.86 & 2 & 0.17 & 0.027 & 2 & 0.002 \\
\hline $5 / 23 / 13$ & TR02 & bottom & 5.6 & 2 & 0.2 & 0.20 & 2 & 0.02 & 5.03 & 2 & 0.06 & 7.92 & 2 & 0.11 & 0.024 & 2 & 0.000 \\
\hline $5 / 23 / 13$ & TR03 & surface & 6.3 & 2 & 0.3 & 0.35 & 2 & 0.30 & 5.02 & 2 & 0.04 & 7.81 & 2 & 0.17 & 0.023 & 2 & 0.004 \\
\hline $5 / 23 / 13$ & TR03 & bottom & 6.2 & 2 & 0.2 & 0.37 & 2 & 0.11 & 5.06 & 2 & 0.05 & 8.01 & 2 & 0.10 & 0.029 & 2 & 0.003 \\
\hline
\end{tabular}




\begin{tabular}{|c|c|c|c|c|c|c|c|c|c|c|c|c|c|c|c|c|c|}
\hline \multirow[b]{3}{*}{ Date } & \multirow[b]{3}{*}{ Site } & \multirow[b]{3}{*}{ Depth } & \multicolumn{3}{|c|}{$\mathrm{Fe}$} & \multicolumn{3}{|c|}{$\mathrm{Mn}$} & \multicolumn{3}{|c|}{ As } & \multicolumn{3}{|c|}{ v } & \multicolumn{3}{|c|}{ Co } \\
\hline & & & $\boldsymbol{\mu g} L^{-1}$ & & & $\mu g L^{-1}$ & & & $\mu \mathrm{g}^{-1}$ & & & $\mu \mathrm{g} \mathrm{L}^{-1}$ & & & $\mu g L^{-1}$ & & \\
\hline & & & Mean & $\mathrm{n}$ & S.D. & Mean & $\mathrm{n}$ & S.D. & Mean & $\mathrm{n}$ & S.D. & Mean & $\mathrm{n}$ & S.D. & Mean & $\mathrm{n}$ & S.D. \\
\hline $6 / 13 / 13$ & $\mathrm{LC} 01$ & surface & 8.3 & 2 & 3.2 & 0.37 & 2 & 0.32 & 7.85 & 2 & 0.36 & 10.43 & 2 & 0.23 & 0.033 & 2 & 0.001 \\
\hline $6 / 13 / 13$ & LC02 & surface & 6.3 & 2 & 0.2 & 0.22 & 2 & 0.05 & 7.65 & 2 & 0.04 & 9.83 & 2 & 0.09 & 0.038 & 2 & 0.001 \\
\hline $6 / 13 / 13$ & $\mathrm{LC} 03$ & surface & 7.6 & 2 & 2.2 & 0.45 & 2 & 0.35 & 6.86 & 2 & 0.07 & 10.89 & 2 & 0.08 & 0.050 & 2 & 0.005 \\
\hline $6 / 13 / 13$ & LN01 & surface & 8.3 & 2 & 1.9 & 0.27 & 2 & 0.32 & 6.41 & 2 & 0.09 & 8.64 & 2 & 0.25 & 0.027 & 2 & 0.002 \\
\hline $6 / 13 / 13$ & LN02 & surface & 6.3 & 2 & 0.2 & 0.22 & 2 & 0.05 & 7.65 & 2 & 0.04 & 9.83 & 2 & 0.09 & 0.038 & 2 & 0.001 \\
\hline $6 / 13 / 13$ & LN03 & surface & 7.3 & 2 & 1.0 & 0.74 & 2 & 0.32 & 7.36 & 2 & 0.06 & 11.32 & 2 & 0.06 & 0.049 & 2 & 0.004 \\
\hline $6 / 13 / 13$ & LS01 & surface & 7.6 & 2 & 0.1 & 0.44 & 2 & 0.35 & 7.30 & 2 & 0.03 & 9.59 & 2 & 0.01 & 0.042 & 2 & 0.004 \\
\hline $6 / 13 / 13$ & LS02 & surface & 8.0 & 2 & 1.0 & 0.37 & 2 & 0.05 & 7.37 & 2 & 0.00 & 9.52 & 2 & 0.03 & 0.038 & 2 & 0.004 \\
\hline $6 / 13 / 13$ & LS03 & surface & 8.4 & 2 & 2.1 & 0.48 & 2 & 0.24 & 7.41 & 2 & 0.07 & 9.79 & 2 & 0.03 & 0.039 & 2 & 0.001 \\
\hline $6 / 13 / 13$ & OC01 & surface & 9.3 & 2 & 1.1 & 0.63 & 2 & 0.38 & 7.98 & 2 & 0.03 & 8.90 & 2 & 0.03 & 0.034 & 2 & 0.005 \\
\hline $6 / 13 / 13$ & $\mathrm{OC} 02$ & surface & 7.7 & 2 & 0.3 & 0.26 & 2 & 0.01 & 7.60 & 2 & 0.03 & 9.19 & 2 & 0.01 & 0.037 & 2 & 0.001 \\
\hline $6 / 13 / 13$ & $\mathrm{OC} 03$ & surface & 8.5 & 2 & 0.6 & 0.61 & 2 & 0.04 & 7.63 & 2 & 0.02 & 9.16 & 2 & 0.00 & 0.037 & 2 & 0.003 \\
\hline $6 / 13 / 13$ & ON01 & surface & 10.2 & 2 & 4.1 & 0.66 & 2 & 0.47 & 6.96 & 2 & 0.04 & 9.90 & 2 & 0.05 & 0.036 & 2 & 0.002 \\
\hline $6 / 13 / 13$ & ON02 & surface & 8.4 & 2 & 0.0 & 0.61 & 2 & 0.01 & 6.88 & 2 & 0.02 & 9.71 & 2 & 0.02 & 0.038 & 2 & 0.005 \\
\hline $6 / 13 / 13$ & ON03 & surface & 7.2 & 2 & 0.2 & 0.42 & 2 & 0.29 & 7.04 & 2 & 0.04 & 9.91 & 2 & 0.13 & 0.039 & 2 & 0.003 \\
\hline $6 / 13 / 13$ & OS01 & surface & 7.6 & 2 & 0.9 & 0.39 & 2 & 0.15 & 7.47 & 2 & 0.29 & 9.54 & 2 & 0.18 & 0.041 & 2 & 0.003 \\
\hline $6 / 13 / 13$ & $\mathrm{OS} 02$ & surface & 6.8 & 2 & 0.2 & 0.39 & 2 & 0.01 & 6.80 & 2 & 0.05 & 9.33 & 2 & 0.01 & 0.043 & 2 & 0.001 \\
\hline $6 / 13 / 13$ & OS03 & surface & 7.1 & 2 & 0.3 & 0.43 & 2 & 0.05 & 7.15 & 2 & 0.02 & 9.64 & 2 & 0.21 & 0.047 & 2 & 0.002 \\
\hline $6 / 13 / 13$ & TR01 & surface & 6.6 & 2 & 0.0 & 0.13 & 2 & 0.00 & 7.02 & 2 & 0.05 & 9.31 & 2 & 0.12 & 0.032 & 2 & 0.001 \\
\hline $6 / 13 / 13$ & TR01 & bottom & 6.6 & 2 & 0.2 & 0.23 & 2 & 0.01 & 6.94 & 2 & 0.02 & 9.16 & 2 & 0.11 & 0.032 & 2 & 0.000 \\
\hline $6 / 13 / 13$ & TR02 & surface & 7.0 & 2 & 0.2 & 0.34 & 2 & 0.21 & 7.01 & 2 & 0.07 & 9.19 & 2 & 0.18 & 0.035 & 2 & 0.003 \\
\hline $6 / 13 / 13$ & TR02 & bottom & 7.0 & 2 & 0.6 & 0.20 & 2 & 0.02 & 6.99 & 2 & 0.04 & 9.10 & 2 & 0.07 & 0.033 & 2 & 0.002 \\
\hline $6 / 13 / 13$ & TR03 & surface & 8.0 & 2 & 0.1 & 0.67 & 2 & 0.03 & 7.24 & 2 & 0.01 & 9.76 & 2 & 0.02 & 0.047 & 2 & 0.001 \\
\hline $6 / 13 / 13$ & TR03 & bottom & 7.0 & 2 & 0.7 & 0.52 & 2 & 0.10 & 7.33 & 2 & 0.02 & 9.90 & 2 & 0.07 & 0.044 & 2 & 0.008 \\
\hline $7 / 3 / 13$ & LC01 & surface & 10.1 & 2 & 0.4 & 0.47 & 2 & 0.01 & 9.75 & 2 & 0.06 & 10.29 & 2 & 0.10 & 0.056 & 2 & 0.001 \\
\hline $7 / 3 / 13$ & LC02 & surface & 10.6 & 2 & 0.9 & 0.53 & 2 & 0.22 & 8.30 & 2 & 0.04 & 10.41 & 2 & 0.01 & 0.054 & 2 & 0.004 \\
\hline $7 / 3 / 13$ & LC03 & surface & 11.8 & 2 & 0.5 & 0.98 & 2 & 0.44 & 8.63 & 2 & 0.06 & 11.58 & 2 & 0.10 & 0.087 & 2 & 0.003 \\
\hline $7 / 3 / 13$ & LN01 & surface & 6.7 & 2 & 0.2 & 0.99 & 2 & 0.10 & 12.58 & 2 & 0.05 & 11.19 & 2 & 0.04 & 0.069 & 2 & 0.004 \\
\hline $7 / 3 / 13$ & LN02 & surface & 6.0 & 2 & 0.2 & 1.07 & 2 & 0.20 & 9.41 & 2 & 0.01 & 11.37 & 2 & 0.07 & 0.068 & 2 & 0.000 \\
\hline $7 / 3 / 13$ & LN03 & surface & 5.6 & 2 & 0.4 & 0.66 & 2 & 0.15 & 9.43 & 2 & 0.08 & 11.51 & 2 & 0.11 & 0.067 & 2 & 0.002 \\
\hline $7 / 3 / 13$ & LS01 & surface & 6.1 & 2 & 0.1 & 0.62 & 2 & 0.16 & 9.16 & 2 & 0.06 & 10.58 & 2 & 0.02 & 0.064 & 2 & 0.010 \\
\hline
\end{tabular}




\begin{tabular}{|c|c|c|c|c|c|c|c|c|c|c|c|c|c|c|c|c|c|}
\hline \multirow[b]{3}{*}{ Date } & \multirow[b]{3}{*}{ Site } & \multicolumn{4}{|c|}{$\mathrm{Fe}$} & \multicolumn{3}{|c|}{$\mathrm{Mn}$} & \multicolumn{3}{|c|}{ As } & \multicolumn{3}{|c|}{ V } & \multicolumn{3}{|c|}{ Co } \\
\hline & & & $\mu g L^{-1}$ & & & $\mu \mathrm{g}^{-1}$ & & & $\mu \mathrm{g} \mathrm{L}^{-1}$ & & & $\mu \mathrm{g} \mathrm{L}^{-1}$ & & & $\mu \mathrm{g} \mathrm{L}^{-1}$ & & \\
\hline & & Depth & Mean & $\mathrm{n}$ & S.D. & Mean & $\mathrm{n}$ & S.D. & Mean & $\mathrm{n}$ & S.D. & Mean & $\mathrm{n}$ & S.D. & Mean & $\mathrm{n}$ & S.D. \\
\hline $7 / 3 / 13$ & LS02 & surface & 5.8 & 2 & 0.2 & 0.43 & 2 & 0.03 & 9.16 & 2 & 0.09 & 10.56 & 2 & 0.03 & 0.058 & 2 & 0.001 \\
\hline $7 / 3 / 13$ & LS03 & surface & 9.1 & 2 & 3.2 & 1.66 & 2 & 1.54 & 9.28 & 2 & 0.12 & 10.51 & 2 & 0.16 & 0.058 & 2 & 0.005 \\
\hline $7 / 3 / 13$ & OC01 & surface & 11.1 & 2 & 0.1 & 0.57 & 2 & 0.48 & 9.18 & 2 & 0.12 & 11.11 & 2 & 0.35 & 0.065 & 2 & 0.010 \\
\hline $7 / 3 / 13$ & OC02 & surface & 13.7 & 2 & 4.7 & 0.78 & 2 & 0.60 & 8.39 & 2 & 0.12 & 10.46 & 2 & 0.08 & 0.064 & 2 & 0.003 \\
\hline $7 / 3 / 13$ & $\mathrm{OC} 03$ & surface & 15.4 & 2 & 0.1 & 1.07 & 2 & 0.06 & 8.51 & 2 & 0.15 & 10.34 & 2 & 0.20 & 0.066 & 2 & 0.003 \\
\hline $7 / 3 / 13$ & ON01 & surface & 6.5 & 2 & 0.5 & 0.78 & 2 & 0.16 & 9.30 & 2 & 0.00 & 11.40 & 2 & 0.04 & 0.064 & 2 & 0.007 \\
\hline $7 / 3 / 13$ & ON02 & surface & 6.4 & 2 & 1.4 & 0.80 & 2 & 0.36 & 9.54 & 2 & 0.01 & 11.17 & 2 & 0.02 & 0.058 & 2 & 0.002 \\
\hline $7 / 3 / 13$ & ON03 & surface & 5.7 & 2 & 0.1 & 0.84 & 2 & 0.09 & 9.23 & 2 & 0.01 & 11.30 & 2 & 0.04 & 0.063 & 2 & 0.004 \\
\hline $7 / 3 / 13$ & OS01 & surface & 5.0 & 2 & 0.2 & 0.28 & 2 & 0.17 & 9.73 & 2 & 0.01 & 11.29 & 2 & 0.01 & 0.060 & 2 & 0.000 \\
\hline $7 / 3 / 13$ & OS02 & surface & 6.1 & 2 & 0.9 & 1.26 & 2 & 0.56 & 9.24 & 2 & 0.03 & 10.38 & 2 & 0.02 & 0.052 & 2 & 0.008 \\
\hline $7 / 3 / 13$ & OS03 & surface & 7.4 & 2 & 2.3 & 1.35 & 2 & 1.18 & 9.58 & 2 & 0.10 & 11.26 & 2 & 0.11 & 0.079 & 2 & 0.023 \\
\hline $7 / 3 / 13$ & TR01 & surface & 5.9 & 2 & 0.4 & 0.44 & 2 & 0.02 & 10.10 & 2 & 0.00 & 11.51 & 2 & 0.06 & 0.061 & 2 & 0.005 \\
\hline $7 / 3 / 13$ & TR01 & bottom & 7.1 & 2 & 0.7 & 0.71 & 2 & 0.15 & 10.04 & 2 & 0.10 & 11.23 & 2 & 0.01 & 0.066 & 2 & 0.014 \\
\hline $7 / 3 / 13$ & TR02 & surface & 4.5 & 2 & 0.2 & 0.87 & 2 & 0.00 & 9.95 & 2 & 0.03 & 11.29 & 2 & 0.12 & 0.073 & 2 & 0.001 \\
\hline $7 / 3 / 13$ & TR02 & bottom & 7.1 & 2 & 1.8 & 1.29 & 2 & 0.45 & 10.09 & 2 & 0.18 & 11.68 & 2 & 0.42 & 0.076 & 2 & 0.001 \\
\hline $7 / 3 / 13$ & TR03 & surface & 5.2 & 2 & 0.3 & 1.20 & 2 & 0.23 & 9.72 & 2 & 0.26 & 10.88 & 2 & 0.33 & 0.071 & 2 & 0.002 \\
\hline $7 / 3 / 13$ & TR03 & bottom & 5.6 & 2 & 1.0 & 1.06 & 2 & 0.07 & 9.92 & 2 & 0.03 & 11.13 & 2 & 0.01 & 0.071 & 2 & 0.006 \\
\hline
\end{tabular}




\begin{tabular}{|c|c|c|c|c|c|c|c|c|c|c|c|c|c|c|c|c|c|}
\hline \multirow[b]{3}{*}{ Date } & \multirow[b]{3}{*}{ Site } & \multirow[b]{3}{*}{ Depth } & \multicolumn{3}{|c|}{$\mathrm{Ni}$} & \multicolumn{3}{|c|}{$\mathrm{Cu}$} & \multicolumn{3}{|c|}{$\mathrm{Zn}$} & \multicolumn{3}{|c|}{$\mathrm{Cd}$} & \multicolumn{3}{|c|}{$\mathrm{Pb}$} \\
\hline & & & \multicolumn{3}{|l|}{$\mu g L^{-1}$} & \multicolumn{3}{|l|}{$\mu g L^{-1}$} & \multicolumn{3}{|l|}{$\mu g L^{-1}$} & \multicolumn{2}{|l|}{$\mu g L^{-1}$} & \multicolumn{4}{|c|}{$\mu g L^{-1}$} \\
\hline & & & Mean & $\mathrm{n}$ & S.D. & Mean & $\mathrm{n}$ & S.D. & Mean & $\mathrm{n}$ & S.D. & Mean & $\mathrm{n}$ & S.D. & Mean & $\mathrm{n}$ & S.D. \\
\hline $4 / 30 / 13$ & MDN & surface & 0.89 & 2 & 0.37 & 1.05 & 2 & 0.12 & 1.29 & 2 & 0.09 & $<0.002$ & 2 & & $<0.002$ & 2 & \\
\hline $4 / 30 / 13$ & Recon TR & surface & 0.46 & 2 & 0.00 & 0.68 & 2 & 0.03 & 0.57 & 2 & 0.11 & $<0.002$ & 2 & & $<0.002$ & 2 & \\
\hline $4 / 30 / 13$ & Recon TR & bottom & 0.45 & 2 & 0.02 & 0.66 & 2 & 0.04 & 0.36 & 2 & 0.07 & $<0.002$ & 2 & & 0.008 & 1 & \\
\hline $5 / 23 / 13$ & $\mathrm{LC} 01$ & surface & 0.12 & 2 & 0.01 & 0.22 & 2 & 0.04 & 0.54 & 2 & 0.16 & $<0.002$ & 2 & & $<0.002$ & 2 & \\
\hline $5 / 23 / 13$ & $\mathrm{LC} 02$ & surface & 0.12 & 2 & 0.01 & 0.27 & 2 & 0.10 & 0.22 & 2 & 0.14 & $<0.002$ & 2 & & 0.006 & 1 & \\
\hline $5 / 23 / 13$ & $\mathrm{LC} 03$ & surface & 0.16 & 2 & 0.01 & 0.38 & 2 & 0.01 & 0.84 & 2 & 0.32 & 0.004 & 2 & 0.001 & 0.004 & 1 & \\
\hline $5 / 23 / 13$ & LN01 & surface & $<0.05$ & 2 & & 0.02 & 2 & 0.01 & 0.18 & 1 & & $<0.002$ & 2 & & 0.002 & 1 & \\
\hline $5 / 23 / 13$ & LN02 & surface & $<0.05$ & 2 & & 0.05 & 2 & 0.02 & 0.29 & 2 & 0.04 & $<0.002$ & 2 & & 0.004 & 2 & 0.002 \\
\hline $5 / 23 / 13$ & LN03 & surface & $<0.05$ & 2 & & 0.05 & 2 & 0.00 & 0.52 & 1 & & $<0.002$ & 2 & & 0.004 & 1 & \\
\hline $5 / 23 / 13$ & LS01 & surface & $<0.05$ & 2 & & 0.16 & 2 & 0.01 & 1.25 & 1 & & $<0.002$ & 2 & & 0.004 & 2 & 0.000 \\
\hline $5 / 23 / 13$ & LS02 & surface & $<0.05$ & 2 & & 0.16 & 2 & 0.00 & 0.10 & 1 & & $<0.002$ & 2 & & 0.004 & 2 & 0.002 \\
\hline $5 / 23 / 13$ & LS03 & surface & $<0.05$ & 2 & & 0.17 & 2 & 0.01 & $<0.10$ & 2 & & $<0.002$ & 2 & & 0.005 & 2 & 0.000 \\
\hline $5 / 23 / 13$ & OC01 & surface & $<0.05$ & 2 & & 0.10 & 2 & 0.03 & 0.27 & 1 & & $<0.002$ & 2 & & 0.004 & 1 & \\
\hline $5 / 23 / 13$ & $\mathrm{OC} 02$ & surface & 0.15 & 2 & 0.01 & 0.34 & 2 & 0.00 & 0.57 & 2 & 0.07 & 0.023 & 1 & & 0.003 & 2 & 0.002 \\
\hline $5 / 23 / 13$ & $\mathrm{OC} 03$ & surface & 0.08 & 2 & 0.02 & 0.21 & 2 & 0.07 & 0.16 & 1 & & $<0.002$ & 2 & & 0.019 & 1 & \\
\hline $5 / 23 / 13$ & ON01 & surface & $<0.05$ & 2 & & 0.04 & 2 & 0.00 & 1.54 & 2 & 0.52 & $<0.002$ & 2 & & 0.008 & 2 & 0.002 \\
\hline $5 / 23 / 13$ & ON02 & surface & $<0.05$ & 2 & & 0.05 & 2 & 0.00 & 0.18 & 2 & 0.06 & $<0.002$ & 2 & & $<0.002$ & 2 & \\
\hline $5 / 23 / 13$ & ON03 & surface & $<0.05$ & 2 & & 0.05 & 2 & 0.01 & $<0.10$ & 2 & & $<0.002$ & 2 & & 0.006 & 1 & \\
\hline $5 / 23 / 13$ & OS01 & surface & $<0.05$ & 2 & & 0.05 & 2 & 0.02 & 0.16 & 1 & & $<0.002$ & 2 & & $<0.002$ & 2 & \\
\hline $5 / 23 / 13$ & OS02 & surface & $<0.05$ & 2 & & 0.07 & 2 & 0.02 & 0.39 & 2 & 0.23 & $<0.002$ & 2 & & 0.006 & 1 & \\
\hline $5 / 23 / 13$ & OS03 & surface & 0.05 & 1 & & 0.08 & 2 & 0.01 & 0.63 & 2 & 0.48 & 0.007 & 1 & & 0.007 & 1 & \\
\hline $5 / 23 / 13$ & TR01 & surface & $<0.05$ & 2 & & 0.05 & 2 & 0.00 & 0.18 & 2 & 0.00 & 0.002 & 2 & 0.000 & $<0.002$ & 2 & \\
\hline $5 / 23 / 13$ & TR01 & bottom & $<0.05$ & 2 & & 0.05 & 2 & 0.00 & 0.29 & 2 & 0.00 & $<0.002$ & 2 & & $<0.002$ & 2 & \\
\hline $5 / 23 / 13$ & TR02 & surface & $<0.05$ & 2 & & 0.05 & 2 & 0.01 & 0.19 & 2 & 0.00 & $<0.002$ & 2 & & $<0.002$ & 2 & \\
\hline $5 / 23 / 13$ & TR02 & bottom & $<0.05$ & 2 & & 0.06 & 2 & 0.00 & $<0.10$ & 2 & & $<0.002$ & 2 & & $<0.002$ & 2 & \\
\hline $5 / 23 / 13$ & TR03 & surface & $<0.05$ & 2 & & 0.06 & 2 & 0.01 & 0.55 & 2 & 0.05 & $<0.002$ & 2 & & $<0.002$ & 2 & \\
\hline $5 / 23 / 13$ & TR03 & bottom & $<0.05$ & 2 & & 0.08 & 2 & 0.00 & 0.54 & 2 & 0.04 & $<0.002$ & 2 & & 0.002 & 2 & 0.000 \\
\hline $6 / 13 / 13$ & LC01 & surface & $<0.05$ & 2 & & 0.18 & 2 & 0.08 & $<0.10$ & 2 & & $<0.002$ & 2 & & 0.006 & 1 & \\
\hline $6 / 13 / 13$ & LC02 & surface & $<0.05$ & 2 & & 0.13 & 2 & 0.04 & $<0.10$ & 2 & & $<0.002$ & 2 & & $<0.002$ & 2 & \\
\hline $6 / 13 / 13$ & LC03 & surface & $<0.05$ & 2 & & 0.15 & 2 & 0.01 & $<0.10$ & 2 & & $<0.002$ & 2 & & 0.004 & 1 & \\
\hline $6 / 13 / 13$ & LN01 & surface & $<0.05$ & 2 & & 0.08 & 2 & 0.01 & $<0.10$ & 2 & & $<0.002$ & 2 & & 0.003 & 2 & 0.001 \\
\hline
\end{tabular}




\begin{tabular}{|c|c|c|c|c|c|c|c|c|c|c|c|c|c|c|c|c|}
\hline \multirow[b]{3}{*}{ Date } & \multirow[b]{3}{*}{ Site } & \multirow[b]{3}{*}{ Depth } & \multicolumn{3}{|c|}{$\mathrm{Ni}$} & \multicolumn{3}{|c|}{$\mathrm{Cu}$} & \multicolumn{3}{|c|}{$\mathrm{Zn}$} & \multicolumn{2}{|c|}{$\mathrm{Cd}$} & \multicolumn{3}{|c|}{$\mathrm{Pb}$} \\
\hline & & & $\mu g L^{-1}$ & & & $\mu g L^{-1}$ & & & $\mu \mathrm{g} \mathrm{L}^{-1}$ & & & $\boldsymbol{\mu g} \mathrm{L}^{-1}$ & & $\mu \mathrm{g} \mathrm{L}^{-1}$ & & \\
\hline & & & Mean & $\mathrm{n}$ & S.D. & Mean & $\mathrm{n}$ & S.D. & Mean & $\mathrm{n}$ & S.D. & Mean & n S.D. & Mean & $\mathrm{n}$ & S.D. \\
\hline $6 / 13 / 13$ & LN02 & surface & $<0.05$ & 2 & & 0.13 & 2 & 0.04 & $<0.10$ & 2 & & $<0.002$ & 2 & $<0.002$ & 2 & \\
\hline $6 / 13 / 13$ & LN03 & surface & $<0.05$ & 2 & & 0.26 & 2 & 0.05 & $<0.10$ & 2 & & $<0.002$ & 2 & 0.006 & 2 & 0.001 \\
\hline $6 / 13 / 13$ & LS01 & surface & $<0.05$ & 2 & & 0.21 & 2 & 0.01 & $<0.10$ & 2 & & $<0.002$ & 2 & 0.005 & 1 & \\
\hline $6 / 13 / 13$ & LS02 & surface & $<0.05$ & 2 & & 0.17 & 2 & 0.03 & $<0.10$ & 2 & & $<0.002$ & 2 & 0.003 & 2 & 0.001 \\
\hline 6/13/13 & LS03 & surface & $<0.05$ & 2 & & 0.24 & 2 & 0.07 & $<0.10$ & 2 & & $<0.002$ & 2 & 0.005 & 2 & 0.003 \\
\hline $6 / 13 / 13$ & OC01 & surface & $<0.05$ & 2 & & 0.13 & 2 & 0.01 & $<0.10$ & 2 & & $<0.002$ & 2 & 0.003 & 2 & 0.001 \\
\hline $6 / 13 / 13$ & OC02 & surface & $<0.05$ & 2 & & 0.11 & 2 & 0.01 & $<0.10$ & 2 & & $<0.002$ & 2 & 0.003 & 1 & \\
\hline $6 / 13 / 13$ & $\mathrm{OC} 03$ & surface & $<0.05$ & 2 & & 0.09 & 2 & 0.01 & $<0.10$ & 2 & & $<0.002$ & 2 & 0.002 & 1 & \\
\hline $6 / 13 / 13$ & ON01 & surface & $<0.05$ & 2 & & 0.11 & 2 & 0.01 & $<0.10$ & 2 & & $<0.002$ & 2 & 0.004 & 2 & 0.003 \\
\hline $6 / 13 / 13$ & ON02 & surface & $<0.05$ & 2 & & 0.15 & 2 & 0.02 & $<0.10$ & 2 & & $<0.002$ & 2 & 0.004 & 2 & 0.001 \\
\hline $6 / 13 / 13$ & ON03 & surface & $<0.05$ & 2 & & 0.11 & 2 & 0.00 & $<0.10$ & 2 & & $<0.002$ & 2 & 0.002 & 2 & 0.000 \\
\hline $6 / 13 / 13$ & OS01 & surface & $<0.05$ & 2 & & 0.15 & 2 & 0.04 & $<0.10$ & 2 & & $<0.002$ & 2 & 0.003 & 2 & 0.001 \\
\hline $6 / 13 / 13$ & OS02 & surface & $<0.05$ & 2 & & 0.09 & 2 & 0.01 & $<0.10$ & 2 & & $<0.002$ & 2 & $<0.002$ & 2 & \\
\hline $6 / 13 / 13$ & OS03 & surface & $<0.05$ & 2 & & 0.12 & 2 & 0.01 & $<0.10$ & 2 & & $<0.002$ & 2 & 0.002 & 1 & \\
\hline $6 / 13 / 13$ & TR01 & surface & $<0.05$ & 2 & & 0.19 & 2 & 0.03 & $<0.10$ & 2 & & $<0.002$ & 2 & $<0.002$ & 2 & \\
\hline $6 / 13 / 13$ & TR01 & bottom & $<0.05$ & 2 & & 1.22 & 2 & 0.01 & $<0.10$ & 2 & & $<0.002$ & 2 & 0.003 & 2 & 0.000 \\
\hline $6 / 13 / 13$ & TR02 & surface & $<0.05$ & 2 & & 0.15 & 2 & 0.04 & $<0.10$ & 2 & & $<0.002$ & 2 & 0.003 & 2 & 0.001 \\
\hline $6 / 13 / 13$ & TR02 & bottom & $<0.05$ & 2 & & 0.16 & 2 & 0.02 & $<0.10$ & 2 & & $<0.002$ & 2 & 0.003 & 2 & 0.001 \\
\hline $6 / 13 / 13$ & TR03 & surface & $<0.05$ & 2 & & 0.12 & 2 & 0.02 & $<0.10$ & 2 & & $<0.002$ & 2 & 0.002 & 1 & \\
\hline $6 / 13 / 13$ & TR03 & bottom & $<0.05$ & 2 & & 0.17 & 2 & 0.00 & $<0.10$ & 2 & & $<0.002$ & 2 & 0.003 & 2 & 0.001 \\
\hline $7 / 3 / 13$ & LC01 & surface & $<0.05$ & 2 & & 0.25 & 2 & 0.07 & 2.35 & 2 & 0.01 & $<0.002$ & 2 & 0.003 & 2 & 0.002 \\
\hline $7 / 3 / 13$ & $\mathrm{LC} 02$ & surface & $<0.05$ & 2 & & 0.35 & 2 & 0.17 & 0.35 & 2 & 0.30 & $<0.002$ & 2 & 0.011 & 1 & \\
\hline $7 / 3 / 13$ & LC03 & surface & 0.08 & 2 & 0.00 & 0.33 & 2 & 0.02 & 0.38 & 1 & & $<0.002$ & 2 & 0.003 & 1 & \\
\hline $7 / 3 / 13$ & LN01 & surface & $<0.05$ & 2 & & 0.35 & 2 & 0.06 & 9.27 & 2 & 7.81 & $<0.002$ & 2 & 0.012 & 2 & 0.005 \\
\hline $7 / 3 / 13$ & LN02 & surface & $<0.05$ & 2 & & 0.24 & 2 & 0.00 & 0.31 & 2 & 0.18 & $<0.002$ & 2 & 0.004 & 2 & 0.001 \\
\hline $7 / 3 / 13$ & LN03 & surface & $<0.05$ & 2 & & 0.28 & 2 & 0.02 & 1.57 & 2 & 0.17 & $<0.002$ & 2 & 0.007 & 2 & 0.000 \\
\hline $7 / 3 / 13$ & LS01 & surface & $<0.05$ & 2 & & 0.27 & 2 & 0.02 & 1.77 & 2 & 0.31 & $<0.002$ & 2 & 0.008 & 2 & 0.003 \\
\hline $7 / 3 / 13$ & LS02 & surface & $<0.05$ & 2 & & 0.23 & 2 & 0.00 & 1.24 & 2 & 0.30 & $<0.002$ & 2 & 0.007 & 2 & 0.001 \\
\hline $7 / 3 / 13$ & LS03 & surface & 0.05 & 2 & 0.00 & 0.41 & 2 & 0.01 & 2.92 & 2 & 0.19 & $<0.002$ & 2 & 0.013 & 2 & 0.002 \\
\hline $7 / 3 / 13$ & OC01 & surface & 0.07 & 2 & 0.02 & 0.44 & 2 & 0.07 & 1.25 & 2 & 0.46 & $<0.002$ & 2 & 0.007 & 2 & 0.002 \\
\hline $7 / 3 / 13$ & $\mathrm{OC} 02$ & surface & 0.03 & 2 & & 0.29 & 2 & 0.08 & 7.73 & 2 & 1.53 & $<0.002$ & 2 & 0.006 & 2 & 0.004 \\
\hline $7 / 3 / 13$ & $\mathrm{OC} 03$ & surface & 0.05 & 2 & 0.01 & 0.26 & 2 & 0.04 & 3.65 & 2 & 4.90 & $<0.002$ & 2 & 0.007 & 2 & 0.003 \\
\hline
\end{tabular}




\begin{tabular}{|c|c|c|c|c|c|c|c|c|c|c|c|c|c|c|c|c|c|}
\hline \multirow[b]{3}{*}{ Date } & \multirow[b]{3}{*}{ Site } & \multirow[b]{3}{*}{ Depth } & \multicolumn{3}{|c|}{$\mathrm{Ni}$} & \multicolumn{3}{|c|}{$\mathrm{Cu}$} & \multicolumn{3}{|c|}{$\mathrm{Zn}$} & \multicolumn{3}{|c|}{$\mathrm{Cd}$} & \multicolumn{3}{|c|}{$\mathrm{Pb}$} \\
\hline & & & $\mu g L^{-1}$ & & & $\mu g L^{-1}$ & & & $\mu \mathrm{g} \mathrm{L}^{-1}$ & & & $\mu \mathrm{g} \mathrm{L}^{-1}$ & & & $\mu g L^{-1}$ & & \\
\hline & & & Mean & $\mathrm{n}$ & S.D. & Mean & $\mathrm{n}$ & S.D. & Mean & $\mathrm{n}$ & S.D. & Mean & $\mathrm{n}$ & S.D. & Mean & $\mathrm{n}$ & S.D. \\
\hline $7 / 3 / 13$ & ON01 & surface & $<0.05$ & 2 & & 0.40 & 2 & 0.22 & 2.66 & 2 & 0.18 & $<0.002$ & 2 & & 0.010 & 2 & 0.006 \\
\hline $7 / 3 / 13$ & ON02 & surface & $<0.05$ & 2 & & 0.22 & 2 & 0.02 & 0.73 & 2 & 0.10 & $<0.002$ & 2 & & 0.004 & 2 & 0.001 \\
\hline $7 / 3 / 13$ & ON03 & surface & $<0.05$ & 2 & & 0.27 & 2 & 0.01 & 1.02 & 2 & 0.32 & $<0.002$ & 2 & & 0.006 & 2 & 0.000 \\
\hline $7 / 3 / 13$ & OS01 & surface & $<0.05$ & 2 & & 0.31 & 2 & 0.02 & 1.97 & 2 & 1.03 & $<0.002$ & 2 & & 0.007 & 2 & 0.003 \\
\hline $7 / 3 / 13$ & OS02 & surface & 0.15 & 1 & & 0.55 & 2 & 0.41 & 2.34 & 2 & 0.69 & 0.005 & 1 & & 0.009 & 2 & 0.003 \\
\hline $7 / 3 / 13$ & $\mathrm{OS} 03$ & surface & $<0.05$ & 2 & & 0.73 & 2 & 0.65 & 4.39 & 2 & 4.51 & 0.649 & 1 & & 0.180 & 2 & 0.243 \\
\hline $7 / 3 / 13$ & TR01 & surface & $<0.05$ & 2 & & 0.36 & 2 & 0.05 & 1.89 & 2 & 1.16 & $<0.002$ & 2 & & 0.009 & 2 & 0.000 \\
\hline $7 / 3 / 13$ & TR01 & bottom & $<0.05$ & 2 & & 0.28 & 2 & 0.05 & 0.55 & 2 & 0.38 & $<0.002$ & 2 & & 0.006 & 2 & 0.001 \\
\hline $7 / 3 / 13$ & TR02 & surface & $<0.05$ & 2 & & 0.40 & 2 & 0.03 & 2.42 & 2 & 1.69 & $<0.002$ & 2 & & 0.011 & 2 & 0.002 \\
\hline $7 / 3 / 13$ & TR02 & bottom & $<0.05$ & 2 & & 0.38 & 2 & 0.07 & 1.02 & 1 & & $<0.002$ & 2 & & 0.010 & 2 & 0.000 \\
\hline $7 / 3 / 13$ & TR03 & surface & $<0.05$ & 2 & & 0.33 & 2 & 0.06 & 4.82 & 2 & 5.60 & $<0.002$ & 2 & & 0.011 & 2 & 0.003 \\
\hline $7 / 3 / 13$ & TR03 & bottom & $<0.05$ & 2 & & 0.42 & 2 & 0.03 & 4.27 & 2 & 2.48 & $<0.002$ & 2 & & 0.017 & 2 & 0.010 \\
\hline
\end{tabular}


Table 8. 2013 benthic chlorophyll and pheophytin concentrations in Upper Klamath Lake, Oregon, with associated temperature and specificconductivity measurements.

$\left[\mu \mathrm{S} \mathrm{cm}^{-1}\right.$, microsiemen per centimeter; $\mu \mathrm{g} \mathrm{cm}^{-2}$, microgram per square centimeter; Chl-a, chlorophyll $a$; blank cells, values that are not available; S.D., standard deviation for the specified $\mathrm{n}$ replicates; na, data not available from that time period. Slightly darkened rows in the table for June 13, 2013, are provided to help the reader distinguish results between sampling dates]

\begin{tabular}{|c|c|c|c|c|c|c|c|c|c|c|c|}
\hline \multirow[b]{3}{*}{ Date } & \multirow[b]{3}{*}{ SiteName } & \multirow{3}{*}{ 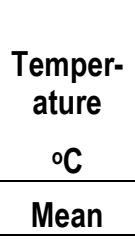 } & \multirow{3}{*}{$\begin{array}{c}\mathrm{pH} \\
\text { Mean } \\
\end{array}$} & \multirow{3}{*}{$\begin{array}{c}\begin{array}{c}\text { Specific } \\
\text { conduc- } \\
\text { tivity }\end{array} \\
\mu \mathrm{Sm}^{-1}\end{array}$} & \multicolumn{3}{|c|}{$\begin{array}{c}\text { Benthic } \\
\text { chlorophyll }\end{array}$} & \multicolumn{3}{|c|}{$\begin{array}{c}\text { Benthic } \\
\text { pheophytin }\end{array}$} & \multirow{3}{*}{$\begin{array}{c}\text { Benthic } \\
\text { Chl-a/Chl-a } \\
+ \text { Pheophytin } \\
\text { Mean } \\
\end{array}$} \\
\hline & & & & & $\mu \mathrm{g} \mathrm{cm}^{-2}$ & & & $\mu \mathrm{g} \mathrm{cm}^{-2}$ & & & \\
\hline & & & & & Mean & $\mathrm{n}$ & S.D. & Mean & $\mathrm{n}$ & S.D. & \\
\hline $4 / 30 / 13$ & MDN_A & 11.5 & 6.7 & 109 & 1.2 & 2 & 0.2 & 4.8 & 2 & 0.4 & 0.20 \\
\hline $4 / 30 / 13$ & MDN_B & 11.5 & 6.7 & 109 & 1.2 & 2 & 0.2 & 4.8 & 2 & 0.4 & 0.20 \\
\hline $4 / 30 / 13$ & MDN_C & 11.5 & 6.7 & 109 & 1.2 & 2 & 0.2 & 4.8 & 2 & 0.4 & 0.20 \\
\hline $4 / 30 / 13$ & TRRecon & 11.2 & 7.0 & 100 & 0.6 & 2 & 0.1 & 2.4 & 2 & 0.5 & 0.20 \\
\hline $5 / 23 / 13$ & LN01 & 12.3 & 7.8 & 107 & 8.8 & 2 & 3.8 & 15.9 & 2 & 4.6 & 0.36 \\
\hline $5 / 23 / 13$ & LN02 & 13.3 & 7.8 & 106 & 7.8 & 2 & 2.6 & 14.9 & 2 & 3.5 & 0.34 \\
\hline $5 / 23 / 13$ & LN03 & 13.1 & 7.8 & 107 & 7.8 & 2 & 1.8 & 24 & 2 & 6.1 & 0.25 \\
\hline $5 / 23 / 13$ & ON01 & 13.1 & 7.8 & 106 & 3.1 & 2 & 0.6 & 11.1 & 2 & 1.8 & 0.22 \\
\hline $5 / 23 / 13$ & $\mathrm{ON} 02$ & 12.7 & 7.5 & 106 & 1.8 & 2 & 0.2 & 7.8 & 2 & 0.2 & 0.19 \\
\hline $5 / 23 / 13$ & ON03 & 13.4 & 7.8 & 106 & 2.1 & 2 & 0.1 & 8.5 & 2 & 0.7 & 0.20 \\
\hline $5 / 23 / 13$ & LC01 & 12.3 & 7.9 & 106 & 7.7 & 2 & 1.3 & 4.4 & 2 & 2.7 & 0.64 \\
\hline $5 / 23 / 13$ & $\mathrm{LC} 02$ & 12.8 & 7.7 & 196 & 9.1 & 2 & 4.3 & 9.3 & 2 & 0.7 & 0.49 \\
\hline $5 / 23 / 13$ & $\mathrm{LC} 03$ & 12.8 & 8.0 & 164 & 9.5 & 2 & 5.3 & 23 & 2 & 8.1 & 0.29 \\
\hline $5 / 23 / 13$ & OC01 & 12.2 & 8.1 & 114 & 1.9 & 2 & 0.8 & 5.2 & 2 & 2.3 & 0.27 \\
\hline $5 / 23 / 13$ & $\mathrm{OC} 02$ & 13.2 & 8.0 & 111 & 1.0 & 2 & 0.1 & 3.5 & 2 & 1.2 & 0.22 \\
\hline $5 / 23 / 13$ & $\mathrm{OC} 03$ & 12.7 & 8.1 & 116 & 2.1 & 2 & 0.4 & 6.8 & 2 & 1.3 & 0.24 \\
\hline $5 / 23 / 13$ & LS01 & 13.0 & 8.3 & 209 & 2.6 & 2 & 0.2 & 9.9 & 2 & 0.8 & 0.21 \\
\hline $5 / 23 / 13$ & LS02 & 12.3 & 8.3 & 205 & 3.7 & 2 & 1.1 & 13.2 & 2 & 1.4 & 0.22 \\
\hline $5 / 23 / 13$ & LS03 & 13.5 & 8.2 & 215 & 3.5 & 2 & 1.0 & 8.7 & 2 & 3.0 & 0.29 \\
\hline $5 / 23 / 13$ & OS01 & 12.6 & 7.7 & 113 & 1.1 & 2 & 0.4 & 6.2 & 2 & 1.6 & 0.15 \\
\hline $5 / 23 / 13$ & OS02 & 12.5 & 8.1 & 106 & 0.5 & 2 & 0.2 & 3.5 & 2 & 0.5 & 0.13 \\
\hline $5 / 23 / 13$ & OS03 & 12.9 & 7.5 & 277 & 1.5 & 2 & 0.3 & 10.5 & 2 & 1.7 & 0.13 \\
\hline $5 / 23 / 13$ & TR01 & 13.1 & 7.9 & 113 & 1.6 & 2 & 1.1 & 8.6 & 2 & 5.3 & 0.16 \\
\hline $5 / 23 / 13$ & TR02 & 13.3 & 8.1 & 113 & 1.7 & 2 & 1.0 & 4.6 & 2 & 0.9 & 0.27 \\
\hline $5 / 23 / 13$ & TR03 & 13.4 & 8.1 & 113 & 1.4 & 2 & 0.3 & 8.1 & 2 & 0.8 & 0.15 \\
\hline
\end{tabular}




\begin{tabular}{|c|c|c|c|c|c|c|c|c|c|c|c|}
\hline \multirow[b]{2}{*}{ Date } & \multirow[b]{2}{*}{ SiteName } & \multirow{2}{*}{$\begin{array}{c}\begin{array}{c}\text { Temper- } \\
\text { ature } \\
{ }^{\circ} \mathrm{C}\end{array} \\
\text { Mean }\end{array}$} & \multirow{2}{*}{$\begin{array}{c}\mathrm{pH} \\
\text { Mean }\end{array}$} & \multirow[t]{2}{*}{$\begin{array}{c}\text { Specific } \\
\text { conduc- } \\
\text { tivity } \\
\mu S \text { cm}^{-1}\end{array}$} & \multicolumn{3}{|c|}{$\begin{array}{l}\text { Benthic } \\
\text { chlorophyll }\end{array}$} & \multicolumn{3}{|c|}{$\begin{array}{c}\text { Benthic } \\
\text { pheophytin }\end{array}$} & \multirow[t]{2}{*}{$\begin{array}{c}\text { Benthic } \\
\text { Chl-a/Chl-a } \\
+ \text { Pheophytin } \\
\text { Mean }\end{array}$} \\
\hline & & & & & Mean & $\mathrm{n}$ & S.D. & Mean & $\mathrm{n}$ & S.D. & \\
\hline $6 / 13 / 13$ & LN01 & 16.7 & 8.7 & 102 & 6.7 & 2 & 0.6 & 9.2 & 2 & 1.8 & 0.42 \\
\hline $6 / 13 / 13$ & LN02 & 17.7 & 9.0 & 113 & 9.3 & 2 & 4.4 & 10.7 & 2 & 2.1 & 0.47 \\
\hline $6 / 13 / 13$ & LN03 & 17.6 & 8.7 & 114 & 8.3 & 2 & 6.9 & 9.9 & 2 & 3.7 & 0.46 \\
\hline $6 / 13 / 13$ & ON01 & 17.4 & 8.3 & 119 & 4.1 & 2 & 0.9 & 10.2 & 2 & 3.3 & 0.29 \\
\hline $6 / 13 / 13$ & ON02 & 17.3 & 8.1 & 119 & 2.6 & 2 & 0.6 & 5.5 & 2 & 0.7 & 0.32 \\
\hline $6 / 13 / 13$ & ON03 & 17.8 & 7.8 & 113 & 4.6 & 2 & 2.5 & 4.3 & 2 & 0.7 & 0.52 \\
\hline $6 / 13 / 13$ & LC01 & 16.3 & 8.6 & 111 & 5.3 & 2 & 0.7 & 9.5 & 2 & 2.3 & 0.36 \\
\hline $6 / 13 / 13$ & $\mathrm{LC} 02$ & 17.6 & 9.2 & 114 & 11.4 & 2 & 3.7 & 6.5 & 2 & 1.1 & 0.64 \\
\hline $6 / 13 / 13$ & LC03 & 16.8 & 8.9 & 112 & 7.1 & 2 & 5.6 & 9.5 & 2 & 3.0 & 0.43 \\
\hline $6 / 13 / 13$ & OC01 & 17.1 & 6.9 & 122 & 4.0 & 2 & 0.9 & 7.6 & 2 & 4.1 & 0.34 \\
\hline $6 / 13 / 13$ & $\mathrm{OC} 02$ & 17.4 & 7.0 & 315 & 1.5 & 2 & 0.1 & 5 & 2 & 0.5 & 0.23 \\
\hline $6 / 13 / 13$ & $\mathrm{OC} 03$ & 16.7 & 6.9 & 305 & 0.9 & 2 & 0.0 & 4 & 2 & 0.3 & 0.18 \\
\hline $6 / 13 / 13$ & LS01 & 17.1 & 7.9 & 113 & 6.3 & 2 & 1.7 & 10.1 & 2 & 2.5 & 0.38 \\
\hline $6 / 13 / 13$ & LS02 & 17.2 & 8.2 & 112 & 6.3 & 2 & 1.0 & 10.4 & 2 & 3.1 & 0.38 \\
\hline $6 / 13 / 13$ & LS03 & 17.5 & 7.9 & 114 & 25.1 & 2 & 13.8 & 7.2 & 2 & 7.8 & 0.78 \\
\hline $6 / 13 / 13$ & OS01 & 16.5 & 9.3 & 124 & 5.3 & 2 & 1.9 & 9.7 & 2 & 1.9 & 0.35 \\
\hline $6 / 13 / 13$ & OS02 & 17.4 & 8.3 & 115 & 1.7 & 2 & 0.2 & 8.2 & 2 & 1.6 & 0.17 \\
\hline $6 / 13 / 13$ & OS03 & 16.4 & 9.3 & 138 & 52.8 & 2 & 37.4 & 29.2 & 2 & 8.9 & 0.64 \\
\hline $6 / 13 / 13$ & TR01 & 17.0 & 6.4 & 117 & 1.2 & 2 & 0.3 & 6.5 & 2 & 1.6 & 0.16 \\
\hline $6 / 13 / 13$ & TR02 & 17.6 & 6.9 & 460 & 0.6 & 2 & 0.1 & 1.9 & 2 & 0.1 & 0.24 \\
\hline $6 / 13 / 13$ & TR03 & 17.9 & 7.1 & 317 & 0.6 & 2 & 0.1 & 5.6 & 2 & 0.3 & 0.10 \\
\hline $7 / 3 / 13$ & LN01 & 22.6 & 9.5 & 247 & & & & & & & \\
\hline $7 / 3 / 13$ & LN02 & 20.1 & 9.5 & 248 & & & & & & & \\
\hline $7 / 3 / 13$ & LN03 & 24.7 & 9.7 & 260 & & & & & & & \\
\hline $7 / 3 / 13$ & ON01 & 20.2 & 9.3 & 251 & & & & & & & \\
\hline $7 / 3 / 13$ & ON02 & 20.4 & 9.4 & 253 & & & & & & & \\
\hline $7 / 3 / 13$ & ON03 & 19.8 & 9.4 & 248 & & & & & & & \\
\hline $7 / 3 / 13$ & LC01 & 21.2 & 9.5 & 239 & & & & & & & \\
\hline $7 / 3 / 13$ & $\mathrm{LC} 02$ & 21.0 & 9.9 & 260 & & & & & & & \\
\hline $7 / 3 / 13$ & LC03 & 20.4 & 9.4 & 244 & & & & & & & \\
\hline
\end{tabular}




\begin{tabular}{|c|c|c|c|c|c|c|c|c|c|c|c|}
\hline \multirow[b]{2}{*}{ Date } & \multirow[b]{2}{*}{ SiteName } & \multirow{2}{*}{$\begin{array}{c}\text { Temper- } \\
\text { ature } \\
{ }^{\circ} \mathrm{C} \\
\text { Mean } \\
\end{array}$} & \multirow{2}{*}{$\begin{array}{c}\mathrm{pH} \\
\text { Mean } \\
\end{array}$} & \multirow{2}{*}{$\begin{array}{c}\begin{array}{c}\text { Specific } \\
\text { conduc- } \\
\text { tivity } \\
\mu S \mathrm{~cm}^{-1}\end{array} \\
\text { Mean } \\
\end{array}$} & \multirow{2}{*}{\multicolumn{2}{|c|}{$\begin{array}{ll} & \text { Benthic } \\
\text { chloroph) } \\
\mu \mathrm{g} \mathrm{cm}^{-2} \\
\text { Mean } \mathrm{n}\end{array}$}} & \multirow[b]{2}{*}{ S.D. } & \multirow{2}{*}{\multicolumn{2}{|c|}{ 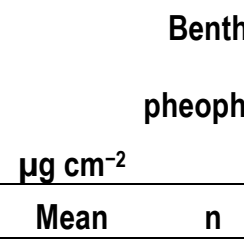 }} & & \multirow{2}{*}{$\begin{array}{c}\text { Benthic } \\
\text { Chl-a/Chl-a } \\
+ \text { Pheophytin } \\
\text { Mean } \\
\end{array}$} \\
\hline & & & & & & & & & & S.D. & \\
\hline $7 / 3 / 13$ & OC01 & 18.8 & 9.7 & 116 & & & & & & & \\
\hline $7 / 3 / 13$ & $\mathrm{OC} 02$ & 21.1 & 9.8 & 118 & & & & & & & \\
\hline $7 / 3 / 13$ & $\mathrm{OC} 03$ & 18.4 & 9.5 & 116 & & & & & & & \\
\hline $7 / 3 / 13$ & LS01 & 23.5 & 8.5 & 245 & & & & & & & \\
\hline $7 / 3 / 13$ & LS02 & 24.1 & 9.2 & 134 & & & & & & & \\
\hline $7 / 3 / 13$ & LS03 & 23.5 & 8.2 & 373 & & & & & & & \\
\hline $7 / 3 / 13$ & OS01 & 22.4 & 9.6 & 220 & & & & & & & \\
\hline $7 / 3 / 13$ & OS02 & 23.5 & 9.2 & na & & & & & & & \\
\hline $7 / 3 / 13$ & OS03 & 22.2 & 9.5 & 385 & & & & & & & \\
\hline $7 / 3 / 13$ & TR01 & 22.4 & 9.6 & 121 & & & & & & & \\
\hline $7 / 3 / 13$ & TR02 & 19.5 & 9.5 & 125 & & & & & & & \\
\hline $7 / 3 / 13$ & TR03 & 20.0 & 9.2 & 121 & & & & & & & \\
\hline
\end{tabular}


Table 9. Mean density of macroinvertebrates per square meter $\left(\mathrm{m}^{-2}\right)$, constancy (presence per sample), and percentage composition of 63 samples (21 samples per date) during 2013.

[Sample density was estimated as the mean of three Ekman grabs per sample. spp., species (plural); cf., confer (a species that closely matches another species); nr., near (taxonomically); sp., species; undet., undetermined; e.i., early instar]

\begin{tabular}{|c|c|c|c|c|c|c|}
\hline \multirow[b]{2}{*}{ Taxon } & \multicolumn{3}{|c|}{$\begin{array}{l}\text { Mean density per date } \\
\quad \text { (individuals } \mathrm{m}^{-2} \text { ) }\end{array}$} & \multirow[t]{2}{*}{$\begin{array}{l}\text { Mean density } \\
\text { for the three } \\
\text { sampling dates } \\
\text { (individuals } \mathrm{m}^{-2} \text { ) }\end{array}$} & \multirow[t]{2}{*}{ Constancy } & \multirow[t]{2}{*}{$\begin{array}{l}\text { Percentage } \\
\text { composition }\end{array}$} \\
\hline & $5 / 23 / 13$ & $6 / 13 / 13$ & $7 / 3 / 13$ & & & \\
\hline Hydra & 12 & 13 & 0 & 8 & 7 & 0.07 \\
\hline Dugesia & 0 & 1 & 0 & 0 & 1 & 0.00 \\
\hline microturbellarians undet. & 1 & 0 & 1 & 0 & 2 & 0.00 \\
\hline mermithids & 6 & 43 & 16 & 21 & 16 & 0.17 \\
\hline Enchytraeidae & 1 & 0 & 0 & 0 & 1 & 0.00 \\
\hline Arcteonais lomondi & 3 & 4 & 1 & 3 & 8 & 0.02 \\
\hline Dero spp. & 28 & 62 & 105 & 65 & 33 & 0.52 \\
\hline Nais spp. & 0 & 4 & 1 & 2 & 5 & 0.01 \\
\hline Slavina appendiculata & 0 & 1 & 1 & 1 & 2 & 0.01 \\
\hline Stylaria & 0 & 1 & 0 & 0 & 1 & 0.00 \\
\hline Naidinae undet. & 3 & 2 & 52 & 19 & 4 & 0.15 \\
\hline Aulodrilus pigueti & 195 & 253 & 308 & 252 & 23 & 2.00 \\
\hline Ilyodrilus frantzi & 1,922 & 1,844 & 1,544 & 1,770 & 63 & 14.04 \\
\hline cf. Limnodrilus hoffmeisteri & 1,275 & 837 & 545 & 886 & 61 & 7.02 \\
\hline Limnodrilus silvani & 54 & 44 & 25 & 41 & 14 & 0.32 \\
\hline Quistadrilus multisetosus & 35 & 56 & 77 & 56 & 21 & 0.45 \\
\hline Rhyacodrilus & 6 & 4 & 6 & 6 & 7 & 0.04 \\
\hline Spirosperma ferox & 7 & 17 & 4 & 9 & 4 & 0.07 \\
\hline Spirosperma nikolskyi & 0 & 2 & 0 & 1 & 2 & 0.01 \\
\hline Varichaetadrilus pacificus & 234 & 293 & 251 & 259 & 21 & 2.05 \\
\hline Varichaetadrilus nr. pacificus & 1,764 & 1,385 & 1,390 & 1,513 & 53 & 12.00 \\
\hline Tubificinae with hairs small & 320 & 701 & 690 & 570 & 50 & 4.52 \\
\hline Bothrioneurum veidovskyanum & 1 & 16 & 1 & 6 & 5 & 0.05 \\
\hline Tubificinae without hairs small & 1,054 & 782 & 372 & 736 & 60 & 5.84 \\
\hline Tubificinae very small & 126 & 49 & 97 & 91 & 44 & 0.72 \\
\hline \multirow[t]{2}{*}{ Altmanella freidris } & 202 & 166 & 143 & 170 & 39 & 1.35 \\
\hline & & & 81 & & & \\
\hline
\end{tabular}




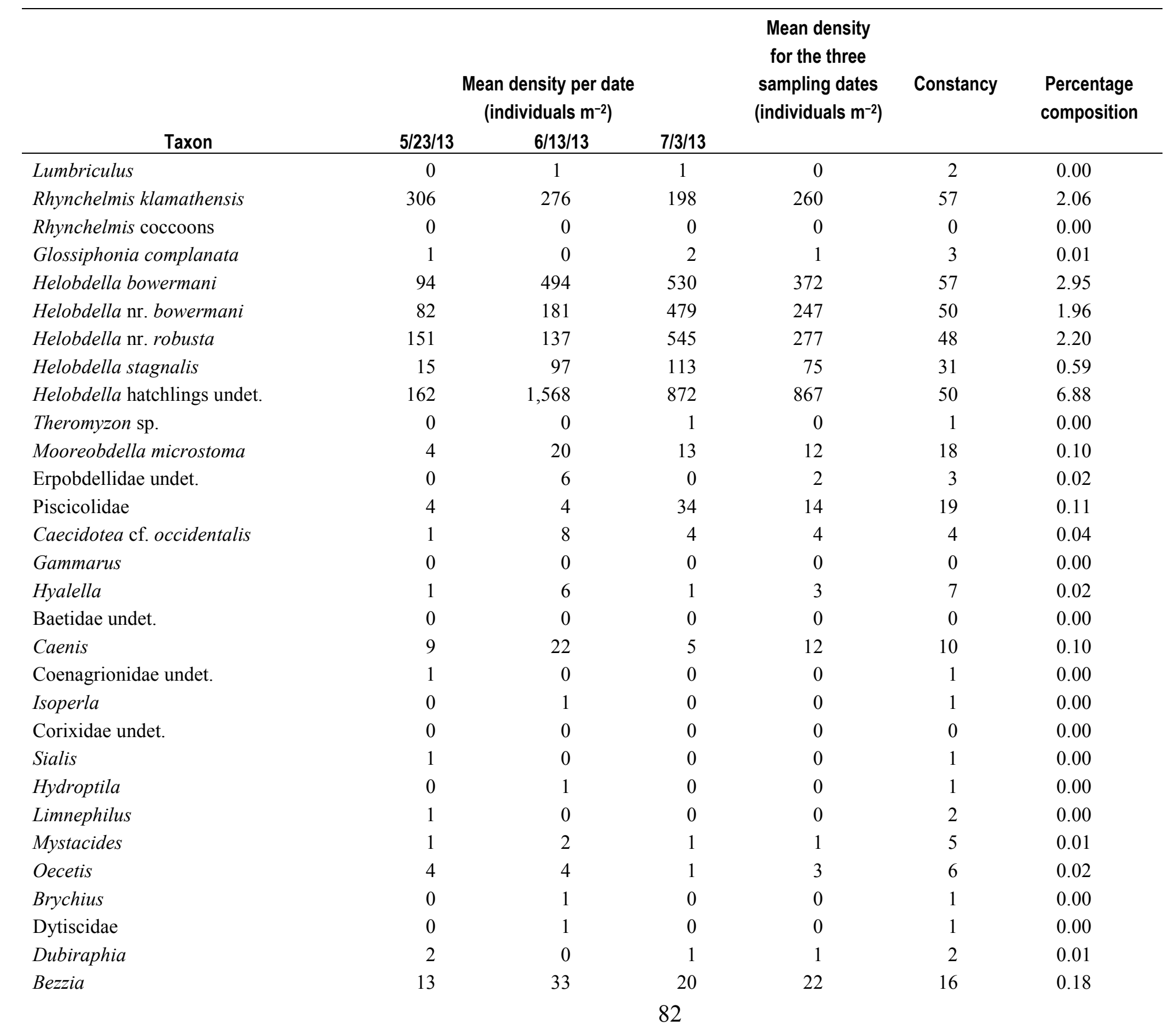




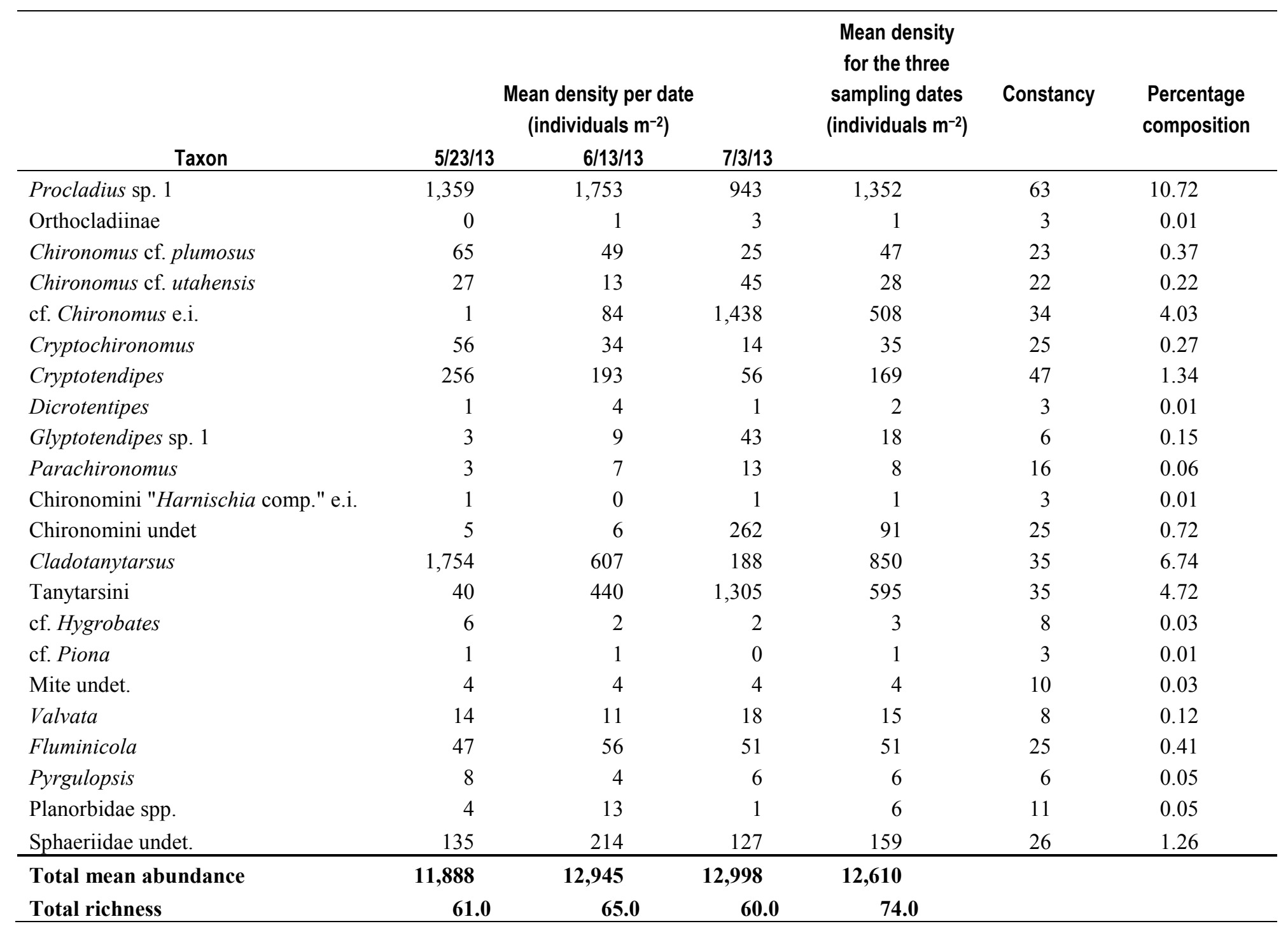


Table 10. Summary of results from 2014 sonde deployments near site ON01 in Upper Klamath Lake, Oregon.

[m, meter; $\mu \mathrm{S} \mathrm{cm}^{-1}$, microsiemen per centimeter; \% DO, percent dissolved oxygen; $\mathrm{mg} \mathrm{L}^{-1}$, milligram per liter; blank cells, values that are not available. Times shown are in Pacific Standard Time. Slightly darkened rows in the table distinguish the bloom period from the pre-bloom and post-bloom periods]

\begin{tabular}{|c|c|c|c|c|c|c|c|c|}
\hline Date & Time & $\begin{array}{c}\text { Depth } \\
\mathrm{m}\end{array}$ & $\begin{array}{c}\text { Specific } \\
\text { conductivity } \\
\mu \mathrm{Sm}^{-1}\end{array}$ & $\begin{array}{c}\text { Temperature } \\
{ }^{\circ} \mathrm{C}\end{array}$ & $\begin{array}{c}\% \text { DO } \\
\text { saturation } \\
\text { (local) }\end{array}$ & $\begin{array}{c}\text { DO } \\
\text { concentration } \\
\mathrm{mg} \mathrm{L}^{-1}\end{array}$ & $\mathrm{pH}$ & $\begin{array}{c}\text { Vertical \% DO } \\
\text { saturation } \\
\text { decrease (\%) }\end{array}$ \\
\hline \multirow[t]{2}{*}{ 4/16/14 } & $10: 00$ & 0.0 & 112 & 12.9 & 100.8 & 9.0 & 7.8 & 1.1 \\
\hline & 10:05 & 2.7 & 112 & 12.5 & 99.7 & 8.9 & 7.7 & \\
\hline \multirow[t]{2}{*}{$4 / 23 / 14$} & $8: 19$ & 0.0 & 115 & 11.7 & 97.0 & 8.9 & 7.4 & 1.1 \\
\hline & $8: 16$ & 2.5 & 115 & 11.7 & 95.9 & 8.8 & 7.4 & \\
\hline \multirow[t]{2}{*}{$4 / 30 / 14$} & 9:59 & 0.0 & 112 & 12.9 & 125.9 & 11.5 & 8.6 & 27.6 \\
\hline & $9: 54$ & 2.2 & 112 & 10.8 & 98.3 & 9.4 & 8.0 & \\
\hline \multirow[t]{2}{*}{$5 / 8 / 14$} & 9:07 & 0.0 & 113 & 12.8 & 100.8 & 9.2 & 7.9 & 3.6 \\
\hline & $9: 13$ & 2.4 & 113 & 12.6 & 97.2 & 8.9 & 7.8 & \\
\hline \multirow[t]{2}{*}{$5 / 14 / 14$} & $9: 26$ & 0.0 & 116 & 15.6 & 111.1 & 9.5 & 7.8 & 30.2 \\
\hline & $9: 32$ & 2.9 & 116 & 12.1 & 80.9 & 7.5 & 7.2 & \\
\hline \multirow[t]{2}{*}{$5 / 21 / 14$} & $10: 05$ & 0.0 & 115 & 15.8 & 101.5 & 8.7 & 7.9 & 4.0 \\
\hline & $10: 00$ & 2.6 & 116 & 15.1 & 97.5 & 8.4 & 7.8 & \\
\hline \multirow[t]{2}{*}{$5 / 29 / 14$} & 9:53 & 0.0 & 117 & 15.9 & 101.1 & 8.6 & 8.1 & 79.7 \\
\hline & $9: 49$ & 2.6 & 117 & 15.4 & 21.4 & 1.8 & 7.9 & \\
\hline \multirow[t]{2}{*}{$6 / 4 / 14$} & $9: 21$ & 0.0 & 118 & 17.6 & 96.8 & 8.0 & 7.9 & 2.0 \\
\hline & $9: 15$ & 2.2 & 118 & 17.4 & 94.8 & 7.8 & 7.9 & \\
\hline \multirow[t]{2}{*}{$6 / 11 / 14$} & $9: 32$ & 0.0 & 120 & 20.1 & 128.9 & 10.1 & 9.2 & 20.2 \\
\hline & $9: 25$ & 2.3 & 119 & 19.4 & 108.7 & 8.6 & 8.9 & \\
\hline \multirow[t]{2}{*}{$6 / 18 / 14$} & $8: 30$ & 0.0 & 122 & 15.9 & 145.2 & 12.4 & 9.5 & 18.1 \\
\hline & $8: 34$ & 2.3 & 120 & 15.6 & 127.1 & 10.9 & 9.7 & \\
\hline \multirow[t]{2}{*}{$6 / 25 / 14$} & $9: 23$ & 0.0 & 127 & 19.3 & 139.1 & 11.0 & 10.1 & 33.0 \\
\hline & $9: 30$ & 2.0 & 124 & 19.0 & 106.1 & 8.5 & 9.9 & \\
\hline \multirow[t]{2}{*}{$7 / 2 / 14$} & 9:07 & 0.0 & 142 & 23.1 & & & 10.3 & \\
\hline & $9: 13$ & 2.1 & 121 & 20.5 & & & 9.8 & \\
\hline \multirow[t]{2}{*}{$7 / 9 / 14$} & $9: 43$ & 0.0 & 121 & 23.6 & 101.5 & 8.6 & 10.0 & 72.4 \\
\hline & $9: 40$ & 2.0 & 118 & 22.3 & 29.1 & 2.5 & 9.6 & \\
\hline \multirow[t]{2}{*}{$7 / 16 / 14$} & $9: 47$ & 0.0 & 121 & 25.7 & & & 9.2 & \\
\hline & $9: 56$ & 2.0 & 122 & 24.7 & & & 8.9 & \\
\hline
\end{tabular}




\begin{tabular}{|c|c|c|c|c|c|c|c|c|}
\hline Date & Time & $\begin{array}{c}\text { Depth } \\
\mathrm{m}\end{array}$ & $\begin{array}{c}\text { Specific } \\
\text { conductivity } \\
\mu \mathrm{S} \mathrm{cm}^{-1}\end{array}$ & $\begin{array}{c}\text { Temperature } \\
{ }^{\circ} \mathrm{C}\end{array}$ & $\begin{array}{c}\% \text { DO } \\
\text { saturation } \\
\text { (local) }\end{array}$ & $\begin{array}{c}\mathrm{DO} \\
\text { concentration } \\
\mathrm{mg} \mathrm{L}^{-1}\end{array}$ & $\mathrm{pH}$ & $\begin{array}{c}\text { Vertical \% DO } \\
\text { saturation } \\
\text { decrease (\%) }\end{array}$ \\
\hline \multirow[t]{2}{*}{$7 / 23 / 14$} & $9: 05$ & 0.0 & 120 & 21.7 & & & 8.8 & \\
\hline & $9: 10$ & 1.9 & 120 & 21.7 & & & 8.8 & \\
\hline \multirow{2}{*}{$7 / 30 / 14$} & $9: 10$ & 0.0 & 116 & 21.3 & 100.1 & 8.1 & 9.3 & 29.5 \\
\hline & $9: 18$ & 1.6 & 116 & 20.9 & 70.6 & 5.8 & 9.2 & \\
\hline \multirow[t]{2}{*}{$8 / 6 / 14$} & $9: 48$ & 0.0 & 117 & 22.1 & 100.0 & 7.1 & 9.1 & 36.1 \\
\hline & $9: 53$ & 1.5 & 121 & 21.5 & 63.9 & 4.6 & 8.7 & \\
\hline \multirow[t]{2}{*}{$8 / 13 / 14$} & 10:06 & 0.0 & 118 & 20.9 & 100.3 & 6.7 & 9.0 & 9.1 \\
\hline & $10: 13$ & 1.6 & 117 & 20.7 & 91.1 & 6.1 & 8.9 & \\
\hline \multirow{2}{*}{$8 / 20 / 14$} & $9: 34$ & 0.0 & 124 & 19.6 & 103.9 & 4.9 & 7.7 & 23.9 \\
\hline & $9: 39$ & 1.5 & 124 & 20.5 & 80.0 & 3.7 & 7.7 & \\
\hline \multirow[t]{2}{*}{$8 / 27 / 14$} & 9:06 & 0.0 & 125 & 20.2 & 100.0 & 6.4 & 8.1 & 16.9 \\
\hline & $9: 15$ & 1.5 & 125 & 20.0 & 83.1 & 5.3 & 7.7 & \\
\hline \multirow[t]{2}{*}{$9 / 4 / 14$} & $9: 40$ & 0.0 & 124 & 17.3 & 101.0 & 8.0 & 8.5 & 3.4 \\
\hline & $9: 36$ & 1.4 & 125 & 17.3 & 97.6 & 7.7 & 8.5 & \\
\hline \multirow[t]{2}{*}{$9 / 10 / 14$} & $9: 29$ & 0.0 & 126 & 16.9 & 101.3 & 7.3 & 8.4 & 1.2 \\
\hline & $9: 22$ & 1.5 & 126 & 16.8 & 100.1 & 7.2 & 8.3 & \\
\hline \multirow[t]{2}{*}{$9 / 17 / 14$} & $9: 16$ & 0.0 & 125 & 17.1 & 100.0 & 8.4 & 8.8 & 21.4 \\
\hline & $9: 22$ & 1.4 & 129 & 18.0 & 78.6 & 6.5 & 8.0 & \\
\hline \multirow[t]{2}{*}{$9 / 24 / 14$} & $9: 50$ & 0.0 & 136 & 16.7 & 100.0 & 6.9 & 6.4 & 21.8 \\
\hline & $9: 57$ & 1.4 & 136 & 16.9 & 78.2 & 5.3 & 7.6 & \\
\hline \multirow[t]{2}{*}{$10 / 1 / 14$} & $9: 18$ & 0.0 & 127 & 13.0 & 98.6 & 6.7 & 7.4 & 0.2 \\
\hline & $9: 13$ & 1.5 & 128 & 12.9 & 98.4 & 6.7 & 7.4 & \\
\hline \multirow[t]{2}{*}{$10 / 8 / 14$} & $9: 41$ & 0.0 & 131 & 14.1 & 98.9 & 5.7 & 7.4 & 1.4 \\
\hline & $9: 49$ & 1.3 & 131 & 14.0 & 97.5 & 5.6 & 7.4 & \\
\hline \multirow[t]{2}{*}{$10 / 16 / 14$} & $9: 30$ & 0.0 & 132 & 10.9 & 99.7 & 7.7 & 7.0 & 7.0 \\
\hline & $9: 38$ & 1.4 & 131 & 10.8 & 92.7 & 7.2 & 7.4 & \\
\hline
\end{tabular}


Table 11. 2014 water-column and pheophytin concentrations in Upper Klamath Lake, Oregon, near site ON01.

$\left[\mu \mathrm{g} \mathrm{L}^{-1}\right.$, microgram per liter; Chl-a, chlorophyll $a$; S.D., standard deviation for the specified $\mathrm{n}$ replicates. Slightly darkened rows in the table distinguish the bloom period from the pre-bloom and post-bloom periods]

\begin{tabular}{|c|c|c|c|c|c|c|c|}
\hline & \multicolumn{3}{|c|}{ Chl-a } & \multicolumn{3}{|c|}{ Pheophytin } & \multirow{3}{*}{$\begin{array}{l}\text { Chl-a/Chl-a } \\
+ \text { Pheophytin }\end{array}$} \\
\hline & \multicolumn{3}{|l|}{$\mu g L^{-1}$} & \multicolumn{3}{|l|}{$\mu g L^{-1}$} & \\
\hline & Mean & $\mathbf{n}$ & S.D. & Mean & $\mathbf{n}$ & S.D. & \\
\hline $4 / 16 / 14$ & 5.66 & 3 & 0.25 & 2.34 & 3 & 0.33 & 0.71 \\
\hline $4 / 23 / 14$ & 6.32 & 3 & 0.50 & 2.83 & 3 & 0.43 & 0.69 \\
\hline $4 / 30 / 14$ & 12.96 & 3 & 0.30 & 3.04 & 3 & 0.31 & 0.81 \\
\hline $5 / 6 / 14$ & 5.49 & 3 & 0.64 & 1.72 & 3 & 0.14 & 0.76 \\
\hline $5 / 14 / 14$ & 4.45 & 3 & 0.52 & 1.42 & 3 & 0.18 & 0.76 \\
\hline $5 / 21 / 14$ & 8.69 & 3 & 0.08 & 2.74 & 3 & 0.44 & 0.76 \\
\hline $5 / 28 / 14$ & 14.46 & 3 & 0.43 & 2.98 & 3 & 0.27 & 0.83 \\
\hline $6 / 4 / 14$ & 18.40 & 3 & 13.70 & 2.89 & 3 & 0.67 & 0.86 \\
\hline $6 / 11 / 14$ & 66.91 & 3 & 26.69 & 5.74 & 3 & 3.17 & 0.92 \\
\hline $6 / 18 / 14$ & 207.27 & 3 & 21.53 & 120.07 & 3 & 87.09 & 0.63 \\
\hline $6 / 25 / 14$ & 98.59 & 3 & 44.18 & 42.89 & 3 & 42.17 & 0.70 \\
\hline $7 / 2 / 14$ & 257.13 & 3 & 24.51 & 156.06 & 3 & 96.18 & 0.62 \\
\hline $7 / 8 / 14$ & 249.75 & 3 & 137.73 & 75.36 & 3 & 36.39 & 0.77 \\
\hline $7 / 15 / 14$ & 67.00 & 3 & 12.76 & 20.57 & 3 & 14.03 & 0.77 \\
\hline $7 / 23 / 14$ & 169.10 & 3 & 70.12 & 17.76 & 3 & 7.18 & 0.90 \\
\hline $7 / 30 / 14$ & 124.52 & 3 & 42.90 & 26.19 & 3 & 16.85 & 0.83 \\
\hline $8 / 6 / 14$ & 103.28 & 3 & 54.86 & 11.59 & 3 & 4.60 & 0.90 \\
\hline $8 / 13 / 14$ & 200.76 & 3 & 35.10 & 26.47 & 3 & 26.65 & 0.88 \\
\hline $8 / 20 / 14$ & 42.11 & 3 & 14.69 & 18.46 & 3 & 12.30 & 0.70 \\
\hline $8 / 27 / 14$ & 44.95 & 3 & 1.53 & 4.00 & 3 & 3.02 & 0.92 \\
\hline $9 / 3 / 14$ & 31.34 & 3 & 4.67 & 4.60 & 3 & 3.74 & 0.87 \\
\hline $9 / 10 / 14$ & 28.11 & 3 & 2.69 & 3.92 & 3 & 1.14 & 0.88 \\
\hline $9 / 17 / 14$ & 21.38 & 3 & 4.92 & 3.68 & 3 & 1.14 & 0.85 \\
\hline $9 / 24 / 14$ & 26.66 & 3 & 0.40 & 4.23 & 3 & 0.66 & 0.86 \\
\hline $10 / 1 / 14$ & 12.22 & 3 & 4.39 & 1.60 & 3 & 0.14 & 0.88 \\
\hline $10 / 8 / 14$ & 6.17 & 3 & 1.55 & 1.69 & 3 & 0.23 & 0.79 \\
\hline $10 / 16 / 14$ & 11.35 & 3 & 1.81 & 5.37 & 3 & 1.68 & 0.68 \\
\hline
\end{tabular}


Table 12. 2014 Dissolved-macronutrient benthic fluxes from profiler deployments in Upper Klamath Lake, Oregon, near site ON01.

$\left[\mathrm{mg} \mathrm{m}^{-2} \mathrm{~d}^{-1}\right.$, milligram per square meter per day; nd, nondetectable benthic flux owing to concentrations from profiler samples that were consistently below detection limits for that solute.; blank cells, flux values that are not available, typically owing to a problem with profiler deployment; S.D., standard deviation for the specified $\mathrm{n}$ replicates. Slightly darkened rows in the table distinguish the bloom period from the pre-bloom and post-bloom periods]

\begin{tabular}{|c|c|c|c|c|c|c|c|c|c|c|c|c|c|c|c|}
\hline \multicolumn{4}{|c|}{$\mathrm{SRP}$ as $\mathrm{P}$} & \multicolumn{3}{|c|}{ Ammonia as $\mathrm{N}$} & \multicolumn{3}{|c|}{ Nitrate as $\mathrm{N}$} & \multicolumn{3}{|c|}{ Silica as $\mathrm{SiO}_{2}$} & \multicolumn{3}{|c|}{$\mathrm{DOC}$ as $\mathrm{C}$} \\
\hline & $\mathrm{mg} \mathrm{m}^{-2} \mathrm{c}$ & & & $\mathrm{mg} \mathrm{m}^{-2}$ & & & $\mathrm{mg} \mathrm{m}^{-2} \mathrm{c}$ & & & $\mathrm{mg} \mathrm{m}^{-}$ & & & $\mathrm{mg} \mathrm{m}^{-2}$ & & \\
\hline Date & Mean & $\mathrm{n}$ & S.D. & Mean & $\mathrm{n}$ & S.D. & Mean & $\mathrm{n}$ & S.D. & Mean & $\mathrm{n}$ & S.D. & Mean & $\mathrm{n}$ & S.D. \\
\hline $4 / 15 / 14$ & 4.06 & 6 & 2.90 & 4.27 & 6 & 4.87 & -0.45 & 6 & 0.33 & 47.0 & 6 & 47.0 & 0.59 & 6 & 1.67 \\
\hline $4 / 22 / 14$ & 1.73 & 6 & 1.43 & 3.91 & 6 & 3.20 & -2.16 & 6 & 0.98 & 18.7 & 6 & 11.0 & -0.80 & 6 & 1.16 \\
\hline $4 / 29 / 14$ & 1.55 & 6 & 0.70 & 3.23 & 6 & 1.25 & -0.97 & 6 & 0.62 & 14.0 & 6 & 13.0 & -3.63 & 6 & 2.87 \\
\hline $5 / 7 / 14$ & 2.65 & 6 & 1.12 & 5.84 & 6 & 7.03 & -0.01 & 1 & & 10.6 & 6 & 6.3 & 0.70 & 6 & 1.09 \\
\hline $5 / 13 / 14$ & 3.42 & 6 & 2.40 & 4.08 & 6 & 1.95 & nd & 6 & & 51.9 & 6 & 46.7 & -0.38 & 6 & 1.13 \\
\hline $5 / 20 / 14$ & 2.82 & 6 & 0.64 & 9.41 & 6 & 9.66 & -0.01 & 1 & & 64.9 & 6 & 55.8 & 0.79 & 6 & 2.47 \\
\hline $5 / 28 / 14$ & 4.26 & 6 & 3.99 & 12.86 & 6 & 13.43 & -0.03 & 3 & 0.04 & 72.4 & 6 & 57.8 & -0.57 & 6 & 1.53 \\
\hline $6 / 3 / 14$ & 2.21 & 6 & 1.33 & 7.57 & 6 & 4.23 & -0.10 & 4 & 0.05 & 53.5 & 6 & 38.6 & -1.88 & 6 & 1.14 \\
\hline $6 / 10 / 14$ & 3.37 & 6 & 2.74 & 9.59 & 6 & 7.87 & -0.07 & 4 & 0.05 & 42.3 & 6 & 30.4 & -0.62 & 6 & 3.36 \\
\hline $6 / 17 / 14$ & 1.17 & 6 & 0.44 & 5.87 & 6 & 1.78 & -0.03 & 5 & 0.04 & 34.5 & 6 & 27.9 & -2.61 & 6 & 1.39 \\
\hline $6 / 24 / 14$ & 1.95 & 6 & 0.69 & 7.57 & 6 & 4.15 & -0.36 & 2 & 0.47 & 43.3 & 6 & 25.1 & -10.60 & 6 & 4.80 \\
\hline $7 / 1 / 14$ & 5.77 & 6 & 4.59 & 11.27 & 6 & 4.93 & -0.69 & 5 & 0.75 & 48.8 & 6 & 25.6 & -6.90 & 6 & 2.29 \\
\hline $7 / 8 / 14$ & 1.70 & 6 & 0.63 & 10.58 & 6 & 4.81 & nd & 6 & & 27.2 & 6 & 17.8 & -9.13 & 6 & 8.80 \\
\hline $7 / 15 / 14$ & 1.62 & 6 & 1.06 & 3.95 & 6 & 2.18 & nd & 6 & & 61.6 & 6 & 58.2 & -5.81 & 6 & 2.68 \\
\hline $7 / 22 / 14$ & 1.68 & 6 & 0.74 & 16.26 & 6 & 6.35 & -1.00 & 3 & 1.00 & 40.5 & 6 & 35.1 & -9.51 & 6 & 5.49 \\
\hline $7 / 29 / 14$ & 5.46 & 6 & 2.34 & 13.50 & 6 & 11.22 & nd & 6 & & 82.8 & 6 & 52.5 & -14.37 & 6 & 7.27 \\
\hline $8 / 5 / 14$ & 3.33 & 6 & 1.43 & 20.62 & 6 & 5.48 & -0.33 & 5 & 0.19 & 106.5 & 6 & 60.4 & -11.41 & 6 & 6.10 \\
\hline $8 / 13 / 14$ & 2.53 & 6 & 1.87 & 10.33 & 6 & 7.27 & -1.45 & 6 & 1.21 & 35.2 & 6 & 35.2 & -6.79 & 6 & 5.08 \\
\hline $8 / 20 / 14$ & 1.82 & 6 & 1.16 & 13.03 & 6 & 11.06 & -6.70 & 3 & 6.59 & 33.0 & 6 & 27.5 & -4.83 & 6 & 1.58 \\
\hline $8 / 27 / 14$ & 2.95 & 6 & 2.31 & 12.75 & 6 & 6.56 & -4.08 & 5 & 1.11 & 32.8 & 6 & 22.5 & -5.52 & 6 & 2.42 \\
\hline $9 / 4 / 14$ & 1.02 & 6 & 0.57 & 4.05 & 6 & 2.11 & -3.50 & 6 & 3.76 & 11.9 & 6 & 6.7 & -4.08 & 6 & 3.37 \\
\hline $9 / 10 / 14$ & 1.01 & 6 & 0.58 & 2.97 & 6 & 2.43 & -0.04 & 1 & & 6.4 & 6 & 3.7 & -1.30 & 6 & 3.63 \\
\hline $9 / 17 / 14$ & 1.21 & 6 & 0.56 & 1.87 & 6 & 0.79 & nd & 6 & & 8.4 & 6 & 6.8 & 11.52 & 6 & 9.07 \\
\hline $9 / 24 / 14$ & 1.36 & 6 & 1.19 & 1.97 & 6 & 2.02 & -0.08 & 5 & 0.03 & 8.5 & 6 & 5.6 & 5.32 & 6 & 9.38 \\
\hline $10 / 1 / 14$ & 0.60 & 6 & 0.60 & 1.74 & 6 & 2.86 & -0.52 & 6 & 0.24 & 7.7 & 6 & 8.0 & 0.17 & 6 & 2.81 \\
\hline $10 / 8 / 14$ & 0.98 & 6 & 0.34 & 8.91 & 6 & 9.85 & -0.40 & 6 & 0.29 & 12.4 & 6 & 8.2 & -1.69 & 6 & 2.18 \\
\hline $10 / 16 / 14$ & 1.74 & 6 & 1.21 & 6.48 & 6 & 4.07 & -0.34 & 5 & 0.22 & 18.1 & 6 & 12.1 & -1.60 & 6 & 1.76 \\
\hline
\end{tabular}


Table 13. Dissolved (0.2-micrometer filtered) macronutrient concentrations in the water column of Upper Klamath Lake, Oregon, near site ON01. [Because the lake is generally shallow (site depths $<3$ meters [m]), water-column samples were collected just below the surface $(\sim 0.5 \mathrm{~m})$, with the exception of the deeper trench (TR) sites (6.0-14.2 m depth). Trench sites were sampled at both the surface and $\sim 1 \mathrm{~m}$ above the lakebed. Blank cells indicate values that are not available. Un-ionized ammonia $\left(\mathrm{NH}_{3}\right)$ concentrations were calculated from temperature and $\mathrm{pH}$ effects on ammonia speciation at their respective depths

(Canadian Council of Ministers of the Environment, 2010). SRP, soluble reactive phosphorus; P, phosphorus; N, nitrogen; DOC, dissolved organic carbon; C, carbon; $\mathrm{mg} \mathrm{L}^{-1}$, milligram per liter; S.D. indicates standard deviation for the specified $\mathrm{n}$ replicates. Slightly darkened rows in the table distinguish the bloom period from the pre-bloom and post-bloom periods]

\begin{tabular}{|c|c|c|c|c|c|c|c|c|c|c|c|c|c|c|c|c|}
\hline \multirow[b]{2}{*}{ Date } & \multicolumn{3}{|c|}{$\begin{array}{l}\text { SRP as } P \\
\mathrm{mg} \mathrm{L}^{-1}\end{array}$} & \multicolumn{4}{|c|}{ Ammonia as $\mathrm{N}$} & \multicolumn{3}{|c|}{ Nitrate as $\mathrm{N}$} & \multicolumn{3}{|c|}{ Silica as $\mathrm{SiO}_{2}$} & $\mathrm{mg} \mathrm{L}^{-1}$ & $\mathrm{C}$ as & \\
\hline & Mean & $\mathbf{n}$ & S.D. & Mean & $\mathbf{n}$ & S.D. & Un-ionized & Mean & $\mathbf{n}$ & S.D. & Mean & $\mathbf{n}$ & S.D. & Mean & $\mathbf{n}$ & S.D. \\
\hline $4 / 15 / 14$ & 0.026 & 2 & 0.001 & $<0.007$ & 2 & & & 0.12 & 2 & 0.00 & 45.5 & 2 & 0.3 & 3.2 & 2 & 0.1 \\
\hline $4 / 22 / 14$ & 0.049 & 2 & 0.004 & 0.036 & 2 & 0.007 & 0.00 & 0.12 & 2 & 0.01 & 43.2 & 2 & 0.8 & 3.8 & 2 & 0.1 \\
\hline $4 / 29 / 14$ & 0.024 & 2 & 0.002 & $<0.007$ & 2 & & & 0.03 & 2 & 0.01 & 41.0 & 2 & 0.5 & 3.2 & 2 & 0.0 \\
\hline $5 / 7 / 14$ & 0.046 & 2 & 0.001 & 0.036 & 2 & 0.001 & 0.00 & 0.02 & 1 & & 48.4 & 2 & 0.0 & 3.9 & 2 & 0.1 \\
\hline $5 / 13 / 14$ & 0.051 & 2 & 0.005 & $<0.007$ & 2 & & & $<0.01$ & 2 & & 44.7 & 2 & 0.1 & 4.0 & 2 & 0.1 \\
\hline $5 / 20 / 14$ & 0.056 & 2 & 0.000 & $<0.007$ & 2 & & & $<0.01$ & 2 & & 43.4 & 2 & 1.1 & 4.1 & 2 & 0.1 \\
\hline $5 / 28 / 14$ & 0.056 & 2 & 0.017 & 0.056 & 2 & 0.001 & 0.00 & 0.06 & 2 & 0.04 & 36.7 & 2 & 1.0 & 3.8 & 2 & 0.0 \\
\hline $6 / 3 / 14$ & 0.091 & 2 & 0.002 & 0.070 & 2 & 0.005 & 0.00 & 0.04 & 2 & 0.02 & 36.0 & 2 & 0.5 & 4.1 & 2 & 0.1 \\
\hline $6 / 10 / 14$ & 0.058 & 2 & 0.000 & 0.017 & 2 & 0.001 & 0.01 & $<0.01$ & 2 & & 36.5 & 2 & 0.0 & 4.4 & 2 & 0.1 \\
\hline $6 / 17 / 14$ & 0.042 & 2 & 0.001 & $<0.007$ & 2 & & & $<0.01$ & 2 & & 36.8 & 2 & 0.4 & 4.2 & 2 & 0.1 \\
\hline $6 / 24 / 14$ & 0.054 & 2 & 0.008 & $<0.007$ & 2 & & & 0.02 & 2 & 0.00 & 40.4 & 2 & 0.3 & 5.5 & 2 & 0.1 \\
\hline $7 / 1 / 14$ & 0.106 & 2 & 0.021 & $<0.007$ & 2 & & & 0.01 & 2 & 0.00 & 37.6 & 2 & 2.7 & 9.3 & 2 & 0.2 \\
\hline $7 / 8 / 14$ & 0.158 & 2 & 0.005 & 0.083 & 2 & 0.011 & 0.07 & 0.05 & 2 & 0.01 & 43.8 & 2 & 0.2 & 9.1 & 2 & 0.2 \\
\hline $7 / 15 / 14$ & 0.246 & 2 & 0.001 & 0.600 & 2 & 0.011 & 0.27 & 0.03 & 2 & 0.01 & 47.7 & 2 & 0.3 & 8.5 & 2 & 0.0 \\
\hline $7 / 22 / 14$ & 0.244 & 2 & 0.001 & 0.575 & 2 & 0.002 & 0.12 & 0.06 & 2 & 0.01 & 51.9 & 2 & 0.2 & 7.4 & 2 & 0.1 \\
\hline $7 / 29 / 14$ & 0.198 & 2 & 0.006 & 0.135 & 2 & 0.004 & 0.06 & 0.06 & 2 & 0.01 & 53.9 & 2 & 0.4 & 7.3 & 2 & 0.0 \\
\hline $8 / 5 / 14$ & 0.179 & 1 & & 0.185 & 2 & 0.014 & 0.07 & 0.07 & 2 & 0.00 & 60.2 & 2 & 0.6 & 7.0 & 2 & 0.0 \\
\hline $8 / 13 / 14$ & 0.134 & 2 & 0.004 & 0.119 & 2 & 0.035 & 0.03 & 0.12 & 2 & 0.01 & 60.6 & 2 & 0.4 & 6.7 & 2 & 0.1 \\
\hline $8 / 20 / 14$ & 0.112 & 2 & 0.000 & 0.243 & 2 & 0.001 & 0.00 & 0.20 & 2 & 0.01 & 61.6 & 2 & 0.3 & 6.4 & 2 & 0.0 \\
\hline $8 / 27 / 14$ & 0.028 & 2 & 0.010 & 0.037 & 2 & 0.022 & 0.00 & 0.17 & 2 & 0.01 & 60.9 & 2 & 0.4 & 5.8 & 2 & 0.0 \\
\hline $9 / 4 / 14$ & 0.033 & 2 & 0.000 & 0.034 & 2 & 0.011 & 0.00 & 0.06 & 2 & 0.00 & 63.0 & 2 & 0.9 & 5.2 & 2 & 0.0 \\
\hline $9 / 10 / 14$ & 0.029 & 2 & 0.000 & 0.042 & 2 & 0.006 & 0.00 & 0.02 & 2 & 0.00 & 64.0 & 2 & 0.1 & 6.9 & 2 & 0.0 \\
\hline $9 / 17 / 14$ & 0.027 & 2 & 0.001 & 0.041 & 2 & 0.001 & 0.01 & $<0.01$ & & & 61.5 & 2 & 0.9 & 4.7 & 2 & 0.0 \\
\hline $9 / 24 / 14$ & 0.032 & 2 & 0.001 & 0.025 & 2 & 0.002 & 0.00 & 0.07 & 2 & 0.00 & 60.6 & 2 & 0.6 & 5.1 & 2 & 0.0 \\
\hline $10 / 1 / 14$ & 0.023 & 2 & 0.001 & 0.090 & 2 & 0.000 & 0.00 & 0.17 & 2 & 0.01 & 56.3 & 2 & 0.3 & 4.5 & 2 & 0.0 \\
\hline $10 / 8 / 14$ & 0.029 & 2 & 0.000 & 0.157 & 2 & 0.004 & 0.00 & 0.14 & 2 & 0.00 & 56.4 & 2 & 0.5 & 4.5 & 2 & 0.0 \\
\hline $10 / 16 / 14$ & 0.019 & 2 & 0.001 & 0.236 & 2 & 0.004 & 0.00 & 0.12 & 2 & 0.00 & 55.3 & 2 & 0.2 & 4.4 & 2 & 0.0 \\
\hline
\end{tabular}


Table 14. 2014 dissolved trace-element benthic fluxes from profiler deployments near site ON01.

[Fe, iron; Mn, manganese; As, arsenic; $\mathrm{V}$, vanadium; $\mathrm{Co}$, cobalt; $\mathrm{Ni}$, nickel; $\mathrm{Cu}$, copper; $\mathrm{Zn}$, zinc; $\mathrm{Cd}$, cadmium; $\mathrm{Pb}$, lead; $\mu \mathrm{g} \mathrm{m}{ }^{-2} \mathrm{~d}^{-1}$, microgram per square meter per day; nd, nondetectable benthic flux due to concentrations from profiler samples that were consistently below detection limits for that solute; blank cells, values that are not available; S.D., standard deviation for the specified $\mathrm{n}$ replicates. Slightly darkened rows in the table distinguish the bloom period from the pre-bloom and post-bloom periods]

\begin{tabular}{|c|c|c|c|c|c|c|c|c|c|c|c|c|c|c|c|}
\hline & $\begin{array}{c}\mathrm{Fe} \\
\mu \mathrm{g} \mathrm{m}^{-2} \mathrm{~d}\end{array}$ & & & $\begin{array}{c}\mathrm{Mn} \\
\mu \mathrm{g} \mathrm{m}^{-2} \mathrm{~d}\end{array}$ & & & $\begin{array}{c}\text { As } \\
\mu \mathrm{g} \mathrm{m}^{-2} \mathrm{~d}\end{array}$ & & & $\begin{array}{c}V \\
\mu g_{~^{-2}} d^{-}\end{array}$ & & & $\begin{array}{c}\text { Co } \\
\mu g^{-2} d^{-}\end{array}$ & & \\
\hline Date & Mean & $\mathrm{n}$ & S.D. & Mean & $\mathrm{n}$ & S.D. & Mean & $\mathrm{n}$ & S.D. & Mean & $\mathrm{n}$ & S.D. & Mean & $\mathrm{n}$ & S.D. \\
\hline $4 / 15 / 14$ & 2,408 & 6 & 1,744 & 573 & 6 & 401 & 26.2 & 6 & 25.4 & -42.19 & 6 & 59.38 & 0.65 & 6 & 0.58 \\
\hline $4 / 22 / 14$ & 2,489 & 6 & 1,076 & 997 & 6 & 463 & 1.6 & 6 & 15.8 & -41.40 & 6 & 40.67 & 0.22 & 6 & 0.19 \\
\hline $4 / 29 / 14$ & 1,917 & 6 & 1,644 & 489 & 6 & 296 & 8.4 & 6 & 13.2 & -40.21 & 6 & 37.59 & 0.09 & 6 & 0.08 \\
\hline $5 / 7 / 14$ & 2,171 & 6 & 1,537 & 1,290 & 6 & 735 & 25.9 & 6 & 43.9 & -78.76 & 6 & 78.64 & 0.19 & 6 & 0.31 \\
\hline $5 / 13 / 14$ & 4,203 & 6 & 2,432 & 793 & 6 & 352 & 1.4 & 6 & 5.7 & -14.88 & 6 & 15.94 & 0.33 & 6 & 0.34 \\
\hline $5 / 20 / 14$ & 3,852 & 6 & 2,897 & 532 & 6 & 173 & -5.7 & 6 & 7.6 & -63.82 & 6 & 54.09 & 0.29 & 6 & 0.45 \\
\hline $5 / 28 / 14$ & 3,904 & 6 & 2,688 & 331 & 6 & 316 & -2.7 & 6 & 2.5 & -24.36 & 6 & 17.66 & 0.15 & 6 & 0.17 \\
\hline $6 / 3 / 14$ & 6,059 & 6 & 6,341 & 833 & 6 & 965 & -8.5 & 6 & 5.5 & -97.57 & 6 & 91.38 & 0.15 & 6 & 0.17 \\
\hline $6 / 10 / 14$ & 5,235 & 6 & 2,243 & 550 & 6 & 277 & -7.1 & 6 & 18.8 & -66.45 & 6 & 72.23 & 0.25 & 6 & 0.28 \\
\hline $6 / 17 / 14$ & 2,991 & 6 & 1,284 & 321 & 6 & 243 & -24.9 & 6 & 39.8 & -60.76 & 6 & 76.63 & 0.05 & 6 & 0.10 \\
\hline $6 / 24 / 14$ & 2,696 & 6 & 1,752 & 280 & 6 & 236 & -12.7 & 6 & 5.8 & -91.42 & 6 & 146.22 & 0.01 & 6 & 0.14 \\
\hline $7 / 1 / 14$ & 3,731 & 6 & 2,943 & 430 & 6 & 349 & -14.4 & 6 & 7.9 & -35.75 & 6 & 10.61 & 0.45 & 6 & 0.63 \\
\hline $7 / 8 / 14$ & 1,051 & 6 & 392 & -6 & 6 & 232 & -13.8 & 6 & 11.8 & -21.81 & 6 & 21.90 & 0.03 & 6 & 0.11 \\
\hline $7 / 15 / 14$ & 1,028 & 6 & 668 & 316 & 6 & 309 & -17.8 & 6 & 14.3 & -38.76 & 6 & 39.77 & 0.12 & 6 & 0.07 \\
\hline $7 / 22 / 14$ & 1,061 & 6 & 729 & 312 & 6 & 348 & -39.3 & 6 & 26.3 & -125.05 & 6 & 183.02 & 0.07 & 6 & 0.12 \\
\hline $7 / 29 / 14$ & 2,166 & 6 & 1,440 & 274 & 6 & 233 & -34.8 & 6 & 18.4 & -18.26 & 6 & 7.51 & 0.16 & 6 & 0.08 \\
\hline $8 / 5 / 14$ & 1,804 & 6 & 929 & 388 & 6 & 165 & -26.9 & 6 & 15.4 & -120.44 & 6 & 80.68 & 0.16 & 6 & 0.15 \\
\hline $8 / 12 / 14$ & 971 & 6 & 431 & 222 & 6 & 110 & -31.0 & 6 & 9.3 & -44.50 & 6 & 44.93 & -0.05 & 6 & 0.13 \\
\hline $8 / 20 / 14$ & 948 & 6 & 894 & 173 & 6 & 184 & -47.9 & 6 & 41.9 & -36.81 & 6 & 34.36 & 0.09 & 6 & 0.22 \\
\hline $8 / 27 / 14$ & 2,748 & 6 & 1,561 & 461 & 6 & 368 & -16.7 & 6 & 8.2 & -73.75 & 6 & 54.46 & 0.04 & 6 & 0.09 \\
\hline $9 / 4 / 14$ & 1,334 & 6 & 1,162 & 412 & 6 & 214 & 70.6 & 6 & 37.4 & -95.95 & 6 & 33.32 & 0.45 & 6 & 0.31 \\
\hline $9 / 10 / 14$ & 1,265 & 6 & 2,181 & 337 & 6 & 294 & 15.3 & 6 & 47.5 & -61.59 & 6 & 50.12 & 0.25 & 6 & 0.30 \\
\hline $9 / 17 / 14$ & 1,487 & 6 & 819 & 591 & 6 & 379 & 68.3 & 6 & 23.0 & -55.46 & 6 & 28.00 & 0.45 & 6 & 0.30 \\
\hline $9 / 24 / 14$ & 1,308 & 6 & 972 & 302 & 6 & 337 & 57.8 & 6 & 51.8 & -33.32 & 6 & 19.36 & 0.43 & 6 & 0.58 \\
\hline $10 / 1 / 14$ & 2,445 & 5 & 2,010 & 279 & 5 & 187 & 27.4 & 5 & 21.8 & -27.47 & 5 & 17.48 & 0.09 & 6 & 0.11 \\
\hline $10 / 8 / 14$ & 3,530 & 6 & 4,662 & 135 & 6 & 74 & -29.3 & 6 & 38.5 & -48.05 & 6 & 51.33 & 0.05 & 6 & 0.09 \\
\hline $10 / 16 / 14$ & 4,290 & 6 & 5,328 & 322 & 6 & 202 & -4.0 & 6 & 88.3 & -37.71 & 6 & 65.20 & 0.22 & 6 & 0.25 \\
\hline
\end{tabular}




\begin{tabular}{|c|c|c|c|c|c|c|c|c|c|c|c|c|c|c|c|}
\hline \multicolumn{3}{|c|}{$\begin{array}{c}\mathrm{Ni} \\
\mu \mathrm{g} \mathrm{m}^{-2} \mathrm{~d}^{-1}\end{array}$} & \multicolumn{3}{|c|}{$\begin{array}{c}\mathrm{Cu} \\
\mu \mathrm{g} \mathrm{m}^{-2} \mathrm{~d}^{-1}\end{array}$} & \multicolumn{3}{|c|}{$\begin{array}{c}\mathrm{Zn} \\
\mu \mathrm{g} \mathrm{m}^{-2} \mathrm{~d}^{-1}\end{array}$} & \multicolumn{3}{|c|}{$\begin{array}{c}C d \\
\mu g m^{-2} d^{-1}\end{array}$} & \multicolumn{4}{|c|}{$\begin{array}{c}\mathrm{Pb} \\
\mu \mathrm{g} \mathrm{m}^{-2} \mathrm{~d}^{-1}\end{array}$} \\
\hline Date & Mean & $\mathrm{n}$ & S.D. & Mean & $\mathrm{n}$ & S.D. & Mean & $\mathrm{n}$ & S.D. & Mean & $\mathrm{n}$ & S.D. & Mean & $\mathrm{n}$ & S.D. \\
\hline $4 / 15 / 14$ & 0.49 & 6 & 0.49 & -0.90 & 6 & 0.41 & 1.24 & 6 & 2.99 & 0.00 & 6 & 0.00 & 0.00 & 6 & 0.00 \\
\hline $4 / 22 / 14$ & -0.20 & 6 & 0.45 & -1.27 & 6 & 0.61 & -0.54 & 6 & 3.78 & 0.00 & 6 & 0.00 & 0.00 & 6 & 0.00 \\
\hline $4 / 29 / 14$ & -0.03 & 6 & 0.22 & -1.84 & 6 & 1.06 & -0.72 & 6 & 0.79 & 0.00 & 6 & 0.00 & 0.00 & 6 & 0.00 \\
\hline $5 / 7 / 14$ & 0.12 & 6 & 0.30 & -0.65 & 6 & 0.43 & 0.00 & 6 & 0.00 & 0.00 & 6 & 0.00 & 0.00 & 6 & 0.00 \\
\hline $5 / 13 / 14$ & 0.28 & 6 & 0.58 & -0.58 & 6 & 0.31 & 0.00 & 6 & 0.00 & 0.00 & 6 & 0.00 & 0.00 & 6 & 0.00 \\
\hline $5 / 20 / 14$ & -0.04 & 6 & 0.26 & -1.85 & 6 & 1.47 & -6.56 & 6 & 7.55 & 0.00 & 6 & 0.00 & 0.00 & 6 & 0.00 \\
\hline $5 / 28 / 14$ & -0.14 & 6 & 0.50 & -1.63 & 6 & 1.30 & -0.63 & 6 & 1.21 & 0.00 & 6 & 0.00 & 0.00 & 6 & 0.00 \\
\hline $6 / 3 / 14$ & -0.10 & 6 & 0.42 & -4.13 & 6 & 7.73 & -19.85 & 6 & 46.26 & 0.00 & 6 & 0.00 & 0.00 & 6 & 0.00 \\
\hline $6 / 10 / 14$ & 0.17 & 6 & 0.33 & -0.63 & 6 & 0.48 & -0.17 & 6 & 1.23 & 0.00 & 6 & 0.00 & 0.00 & 6 & 0.00 \\
\hline $6 / 17 / 14$ & -0.02 & 6 & 0.09 & -0.89 & 6 & 0.77 & 0.12 & 6 & 0.75 & 0.00 & 6 & 0.00 & 0.00 & 6 & 0.00 \\
\hline $6 / 24 / 14$ & -0.03 & 6 & 0.14 & -1.35 & 6 & 0.91 & 1.68 & 6 & 4.98 & 0.00 & 6 & 0.00 & 0.00 & 6 & 0.00 \\
\hline $7 / 1 / 14$ & 0.06 & 6 & 0.39 & -1.36 & 6 & 0.56 & -2.14 & 6 & 7.35 & 0.00 & 6 & 0.00 & 0.00 & 6 & 0.00 \\
\hline $7 / 8 / 14$ & -0.05 & 6 & 0.15 & -0.71 & 6 & 0.75 & -1.49 & 6 & 4.86 & 0.00 & 6 & 0.00 & 0.00 & 6 & 0.00 \\
\hline $7 / 15 / 14$ & -0.08 & 6 & 0.37 & -0.80 & 6 & 1.25 & -0.06 & 6 & 0.76 & 0.00 & 6 & 0.00 & -0.06 & 6 & 0.06 \\
\hline $7 / 22 / 14$ & -0.03 & 6 & 0.11 & -0.26 & 6 & 1.47 & -0.29 & 6 & 1.44 & 0.00 & 6 & 0.00 & -0.02 & 6 & 0.10 \\
\hline $7 / 29 / 14$ & 0.04 & 6 & 0.34 & -0.61 & 6 & 0.58 & -0.19 & 6 & 2.41 & 0.00 & 6 & 0.00 & 0.00 & 6 & 0.00 \\
\hline $8 / 5 / 14$ & -0.07 & 6 & 0.14 & -1.15 & 6 & 0.88 & -0.24 & 6 & 2.60 & 0.00 & 6 & 0.00 & -0.07 & 6 & 0.06 \\
\hline $8 / 12 / 14$ & -0.14 & 6 & 0.06 & -1.42 & 6 & 1.39 & -5.10 & 6 & 7.90 & 0.00 & 6 & 0.00 & -0.04 & 6 & 0.04 \\
\hline $8 / 20 / 14$ & -0.09 & 6 & 0.06 & 9.23 & 6 & 25.04 & -3.61 & 6 & 4.25 & 0.00 & 6 & 0.00 & -0.02 & 6 & 0.01 \\
\hline $8 / 27 / 14$ & -0.18 & 6 & 0.14 & -1.79 & 6 & 0.79 & 2.29 & 6 & 7.50 & 0.00 & 6 & 0.00 & -0.05 & 6 & 0.02 \\
\hline $9 / 4 / 14$ & 0.03 & 6 & 0.18 & -1.05 & 6 & 1.40 & -8.48 & 6 & 28.49 & 0.00 & 6 & 0.00 & 0.00 & 6 & 0.00 \\
\hline $9 / 10 / 14$ & 0.06 & 6 & 0.20 & -0.78 & 6 & 0.71 & 1.46 & 6 & 3.02 & 0.00 & 6 & 0.00 & -0.01 & 6 & 0.02 \\
\hline $9 / 17 / 14$ & 0.39 & 6 & 0.48 & -1.65 & 6 & 1.08 & 0.50 & 6 & 1.08 & 0.00 & 6 & 0.00 & 0.00 & 6 & 0.00 \\
\hline $9 / 24 / 14$ & 0.21 & 6 & 0.19 & 0.49 & 6 & 0.88 & 0.81 & 6 & 15.15 & 0.00 & 6 & 0.00 & 0.03 & 6 & 0.17 \\
\hline $10 / 1 / 14$ & 0.00 & 6 & 0.00 & 0.00 & 5 & 0.00 & 0.79 & 5 & 2.19 & 0.00 & 5 & 0.00 & 0.00 & 5 & 0.00 \\
\hline $10 / 8 / 14$ & 0.00 & 6 & 0.00 & 0.00 & 6 & 0.00 & 0.06 & 6 & 0.15 & 0.00 & 6 & 0.00 & -1.17 & 6 & 2.42 \\
\hline $10 / 16 / 14$ & 0.14 & 6 & 0.18 & -0.27 & 6 & 0.21 & 0.73 & 6 & 1.52 & 0.00 & 6 & 0.00 & 0.00 & 6 & 0.05 \\
\hline
\end{tabular}


Table 15. 2014 dissolved (0.2-micrometer filtered) trace-element concentrations in the water column of Upper Klamath Lake, Oregon, near site ON01.

[[Fe, iron; Mn, manganese; As, arsenic; V, vanadium; Co, cobalt; Ni, nickel; $\mathrm{Cu}$, copper; $\mathrm{Zn}$, zinc; $\mathrm{Cd}$, cadmium; $\mathrm{Pb}$, lead; $\mu \mathrm{g} \mathrm{L}^{-1}$, microgram per liter; blank cells, values that are not available; S.D., standard deviation for the specified $\mathrm{n}$ replicates; na, data not available from that time period. Slightly darkened rows in the table distinguish the bloom period from the pre-bloom and post-bloom periods]

\begin{tabular}{|c|c|c|c|c|c|c|c|c|c|c|c|c|c|c|c|}
\hline & $\begin{array}{c}\mathrm{Fe} \\
\mathrm{ug} \mathrm{L} \mathrm{L}^{-1}\end{array}$ & & & $\begin{array}{c}M n \\
\text { ug } L^{-1}\end{array}$ & & & $\begin{array}{c}\text { As } \\
\text { ug } L^{-1}\end{array}$ & & & $\begin{array}{c}\text { V } \\
\text { ug } L^{-1}\end{array}$ & & & $\begin{array}{c}\text { Co } \\
\text { ug } L^{-1}\end{array}$ & & \\
\hline Date & Mean & $\mathrm{n}$ & S.D. & Mean & $\mathrm{n}$ & S.D. & Mean & $\mathrm{n}$ & S.D. & Mean & $\mathrm{n}$ & S.D. & Mean & $\mathrm{n}$ & S.D. \\
\hline $4 / 15 / 14$ & 26.8 & 2 & 1.9 & 2.4 & 2 & 0.1 & 3.39 & 2 & 0.01 & 10.09 & 2 & 0.09 & 0.042 & 2 & 0.003 \\
\hline $4 / 22 / 14$ & 5.5 & 2 & 0.3 & 0.9 & 2 & 0.2 & 2.79 & 2 & 0.00 & 5.42 & 2 & 0.02 & 0.017 & 2 & 0.002 \\
\hline $4 / 29 / 14$ & 6.2 & 2 & 0.2 & $<0.1$ & 2 & & 2.91 & 2 & 0.03 & 5.60 & 2 & 0.11 & 0.019 & 2 & 0.007 \\
\hline $5 / 7 / 14$ & 6.1 & 2 & 1.2 & $<0.1$ & 2 & & 3.30 & 2 & 0.00 & 5.65 & 2 & 0.05 & 0.019 & 2 & 0.005 \\
\hline $5 / 13 / 14$ & 16.4 & 2 & 0.2 & 0.3 & 2 & 0.0 & 4.11 & 2 & 0.04 & 9.28 & 2 & 0.05 & 0.031 & 2 & 0.001 \\
\hline $5 / 20 / 14$ & 15.8 & 2 & 0.0 & 0.4 & 2 & 0.0 & 4.28 & 2 & 0.00 & 9.35 & 2 & 0.08 & 0.030 & 2 & 0.002 \\
\hline $5 / 28 / 14$ & 15.9 & 2 & 0.6 & 1.3 & 2 & 0.8 & 6.44 & 2 & 0.21 & 9.07 & 2 & 0.19 & 0.032 & 2 & 0.008 \\
\hline $6 / 3 / 14$ & 19.1 & 2 & 0.1 & 3.0 & 2 & 2.2 & 4.80 & 2 & 0.00 & 9.07 & 2 & 0.07 & 0.041 & 2 & 0.006 \\
\hline $6 / 10 / 14$ & 16.9 & 2 & 0.8 & 1.3 & 2 & 0.1 & 5.09 & 2 & 0.10 & 9.79 & 2 & 0.22 & 0.047 & 2 & 0.000 \\
\hline $6 / 17 / 14$ & 16.4 & 2 & 0.9 & 0.7 & 2 & 0.0 & 5.43 & 2 & 0.02 & 10.43 & 2 & 0.05 & 0.056 & 2 & 0.002 \\
\hline $6 / 24 / 14$ & na & & & na & & & na & & & na & & & na & & \\
\hline $7 / 1 / 14$ & 15.8 & 2 & 0.8 & 1.2 & 2 & 0.1 & 6.21 & 2 & 0.01 & 10.54 & 2 & 0.04 & 0.081 & 2 & 0.002 \\
\hline $7 / 8 / 14$ & 18.1 & 2 & 9.8 & 1.7 & 2 & 0.7 & 5.60 & 2 & 0.00 & 6.18 & 2 & 0.10 & 0.057 & 2 & 0.004 \\
\hline $7 / 15 / 14$ & 34.5 & 2 & 6.6 & 1.8 & 2 & 0.1 & 9.15 & 2 & 0.03 & 8.99 & 2 & 0.06 & 0.107 & 2 & 0.001 \\
\hline $7 / 22 / 14$ & 18.9 & 2 & 6.2 & 1.1 & 2 & 0.1 & 10.19 & 2 & 0.07 & 7.78 & 2 & 0.06 & 0.070 & 2 & 0.005 \\
\hline $7 / 29 / 14$ & 16.4 & 2 & 0.6 & 4.0 & 2 & 0.1 & 10.16 & 2 & 0.02 & 6.66 & 2 & 0.02 & 0.078 & 2 & 0.000 \\
\hline $8 / 5 / 14$ & 25.6 & 2 & 1.2 & 2.0 & 2 & 0.2 & 11.94 & 2 & 0.07 & 7.55 & 2 & 0.16 & 0.087 & 2 & 0.000 \\
\hline $8 / 12 / 14$ & 23.8 & 2 & 1.2 & 1.0 & 2 & 0.0 & 11.65 & 2 & 0.10 & 7.18 & 2 & 0.02 & 0.075 & 2 & 0.002 \\
\hline $8 / 19 / 14$ & 31.1 & 2 & 9.9 & 3.8 & 2 & 0.3 & 10.09 & 2 & 0.01 & 5.83 & 2 & 0.22 & 0.068 & 2 & 0.001 \\
\hline $8 / 26 / 14$ & 28.4 & 2 & 4.6 & 3.3 & 2 & 0.0 & 8.50 & 2 & 0.00 & 8.19 & 2 & 0.01 & 0.066 & 2 & 0.000 \\
\hline $9 / 3 / 14$ & 27.9 & 2 & 8.0 & 0.9 & 2 & 0.3 & 7.66 & 2 & 0.04 & 9.76 & 2 & 0.04 & 0.046 & 2 & 0.000 \\
\hline 9/9/14 & 14.5 & 2 & 1.9 & 0.4 & 2 & 0.1 & 7.32 & 2 & 0.09 & 9.73 & 2 & 0.03 & 0.044 & 2 & 0.002 \\
\hline $9 / 16 / 14$ & 13.6 & 2 & 0.5 & 0.8 & 2 & 0.1 & 7.29 & 2 & 0.01 & 8.63 & 2 & 0.00 & 0.036 & 2 & 0.001 \\
\hline $9 / 23 / 14$ & 33.3 & 2 & 3.0 & 3.4 & 2 & 0.0 & 8.26 & 2 & 0.04 & 7.87 & 2 & 0.08 & 0.050 & 2 & 0.001 \\
\hline 9/30/14 & 29.6 & 2 & 0.3 & 3.8 & 2 & 0.0 & 6.16 & 2 & 0.02 & 9.00 & 2 & 0.01 & 0.047 & 2 & 0.000 \\
\hline $10 / 7 / 14$ & 42.4 & 2 & 19.1 & 10.3 & 2 & 1.4 & 6.76 & 2 & 0.09 & 9.36 & 2 & 0.07 & 0.051 & 2 & 0.001 \\
\hline $10 / 14 / 14$ & 27.6 & 2 & 0.6 & 3.5 & 2 & 0.1 & 6.68 & 2 & 0.07 & 11.34 & 2 & 0.20 & 0.038 & 2 & 0.002 \\
\hline
\end{tabular}




\begin{tabular}{|c|c|c|c|c|c|c|c|c|c|c|c|c|c|c|c|}
\hline & $\begin{array}{c}\mathrm{Ni} \\
\mathrm{ug} \mathrm{L}^{-1}\end{array}$ & & & $\begin{array}{c}\mathrm{Cu} \\
\mathrm{ug} \mathrm{L-1}\end{array}$ & & & $\begin{array}{c}\mathrm{Zn} \\
\mathrm{ug} \mathrm{L}^{-1}\end{array}$ & & & $\begin{array}{c}\mathrm{Cd} \\
\mathrm{ug} \mathrm{L-1}\end{array}$ & & & $\begin{array}{c}\mathrm{Pb} \\
\text { ug } \mathrm{L}^{-1}\end{array}$ & & \\
\hline Date & Mean & $\mathrm{n}$ & S.D. & Mean & $\mathrm{n}$ & S.D. & Mean & $\mathrm{n}$ & S.D. & Mean & $\mathrm{n}$ & S.D. & Mean & $\mathrm{n}$ & S.D. \\
\hline $4 / 15 / 14$ & 0.35 & 2 & 0.02 & 0.737 & 2 & 0.050 & 1.4 & 2 & 0.3 & $<0.002$ & 2 & & 0.004 & 1 & \\
\hline $4 / 22 / 14$ & $<0.05$ & 2 & & 0.316 & 2 & 0.023 & 1.6 & 2 & 0.2 & $<0.002$ & 2 & & $<0.002$ & 2 & \\
\hline $4 / 29 / 14$ & $<0.05$ & 2 & & 0.364 & 2 & 0.001 & 4.0 & 2 & 1.0 & $<0.002$ & 2 & & 0.011 & 2 & 0.005 \\
\hline $5 / 7 / 14$ & $<0.05$ & 2 & & 0.304 & 2 & 0.010 & 1.8 & 2 & 1.2 & $<0.002$ & 2 & & $<0.002$ & 2 & \\
\hline $5 / 13 / 14$ & 0.19 & 2 & 0.00 & 0.425 & 2 & 0.001 & 0.6 & 2 & 0.1 & $<0.002$ & 2 & & 0.002 & 1 & \\
\hline $5 / 20 / 14$ & 0.20 & 2 & 0.00 & 0.416 & 2 & 0.016 & 1.7 & 2 & 0.0 & $<0.002$ & 2 & & $<0.002$ & 2 & \\
\hline $5 / 28 / 14$ & 0.05 & 2 & 0.02 & 0.207 & 2 & 0.007 & 1.3 & 2 & 0.2 & $<0.002$ & 2 & & $<0.002$ & 2 & \\
\hline $6 / 3 / 14$ & 0.23 & 2 & 0.03 & 0.437 & 2 & 0.033 & 2.3 & 2 & 1.5 & $<0.002$ & 2 & & 0.019 & 2 & 0.023 \\
\hline $6 / 10 / 14$ & 0.22 & 2 & 0.02 & 0.428 & 2 & 0.025 & 1.7 & 2 & 0.7 & $<0.002$ & 2 & & 0.013 & 2 & 0.013 \\
\hline $6 / 17 / 14$ & 0.20 & 2 & 0.00 & 0.422 & 2 & 0.003 & 0.9 & 2 & 0.1 & $<0.002$ & 2 & & $<0.002$ & 2 & \\
\hline $6 / 24 / 14$ & na & & & na & & & na & & & na & & & na & & \\
\hline $7 / 1 / 14$ & 0.22 & 2 & 0.01 & 0.532 & 2 & 0.011 & 2.8 & 2 & 1.1 & $<0.002$ & 2 & & 0.012 & 2 & 0.008 \\
\hline $7 / 8 / 14$ & $<0.05$ & 2 & & 0.393 & 2 & 0.011 & 8.5 & 2 & 6.2 & 0.003 & 1 & & 0.124 & 2 & 0.159 \\
\hline $7 / 15 / 14$ & 0.18 & 2 & 0.03 & 0.895 & 2 & 0.062 & 11.7 & 2 & 3.3 & 0.004 & 1 & & 0.035 & 2 & 0.030 \\
\hline $7 / 22 / 14$ & $<0.05$ & 2 & & 0.048 & 2 & 0.000 & 5.2 & 2 & 0.0 & $<0.002$ & 2 & & 0.011 & 1 & \\
\hline $7 / 29 / 14$ & 0.19 & 2 & 0.05 & 0.088 & 2 & 0.004 & 9.7 & 2 & 0.1 & $<0.002$ & 2 & & 0.019 & 2 & 0.025 \\
\hline $8 / 5 / 14$ & 0.30 & 2 & 0.00 & 0.446 & 2 & 0.008 & 4.4 & 2 & 0.5 & $<0.002$ & 2 & & 0.012 & 2 & 0.002 \\
\hline $8 / 12 / 14$ & 0.30 & 2 & 0.00 & 0.468 & 2 & 0.072 & 2.0 & 2 & 0.9 & $<0.002$ & 2 & & 0.009 & 2 & 0.003 \\
\hline $8 / 19 / 14$ & 0.33 & 2 & 0.01 & 0.438 & 2 & 0.012 & 1.1 & 2 & 0.5 & $<0.002$ & 2 & & 0.008 & 2 & 0.002 \\
\hline $8 / 26 / 14$ & 0.35 & 2 & 0.01 & 0.368 & 2 & 0.002 & 2.2 & 2 & 1.0 & $<0.002$ & 2 & & 0.006 & 2 & 0.003 \\
\hline $9 / 3 / 14$ & 0.07 & 2 & 0.01 & $<0.01$ & 2 & & 0.5 & 2 & 0.3 & $<0.002$ & 2 & & $<0.002$ & 2 & \\
\hline $9 / 9 / 14$ & 0.06 & 2 & 0.01 & 0.148 & 2 & 0.079 & 6.8 & 2 & 3.1 & $<0.002$ & 2 & & $<0.002$ & 2 & \\
\hline $9 / 16 / 14$ & 0.18 & 2 & 0.04 & 0.259 & 2 & 0.212 & 3.7 & 2 & 2.0 & $<0.002$ & 2 & & 0.032 & 1 & \\
\hline $9 / 23 / 14$ & 0.23 & 2 & 0.01 & 0.193 & 2 & 0.056 & 4.0 & 2 & 1.0 & $<0.002$ & 2 & & $<0.002$ & 2 & \\
\hline $9 / 30 / 14$ & 0.26 & 2 & 0.01 & 0.542 & 2 & 0.482 & 5.0 & 2 & 0.6 & $<0.002$ & 2 & & $<0.002$ & 2 & \\
\hline $10 / 7 / 14$ & 0.31 & 2 & 0.05 & 0.334 & 2 & 0.063 & 5.2 & 2 & 1.5 & $<0.002$ & 2 & & 0.006 & 1 & \\
\hline $10 / 14 / 14$ & 0.20 & 2 & 0.00 & 0.455 & 2 & 0.307 & 0.8 & 2 & 0.5 & $<0.002$ & 2 & & $<0.002$ & 2 & \\
\hline
\end{tabular}


Table 16. Mean density of macroinvertebrates per square meter $\left(\mathrm{m}^{-2}\right)$, mean density per sampling interval, constancy (presence per sample), and percentage composition of 27 weekly samples collected during 2014 at site ON01.

[Sample density was estimated as the mean of five Ekman grabs per sample. Each interval included nine collecting dates: pre-bloom period between April 15 and June 10, 2014; bloom period between June 16 and August 12, 2014; and post-bloom period between August 19 and October 16, 2014. spp., species (plural); cf., confer (a species that closely matches another species); nr., near (taxonomically); sp., species; undet., undetermined; e.i., early instar]

\begin{tabular}{|c|c|c|c|c|c|c|}
\hline \multirow[b]{2}{*}{ Taxon } & \multicolumn{3}{|c|}{$\begin{array}{c}\text { Mean density } \\
\text { (individuals } \mathrm{m}^{-2} \text { ) }\end{array}$} & \multirow[t]{2}{*}{$\begin{array}{l}\text { Mean density } \\
\text { for the three } \\
\text { sampling } \\
\text { periods } \\
\text { (individuals } \mathrm{m}^{-2} \text { ) }\end{array}$} & \multirow[t]{2}{*}{ Constancy } & \multirow[t]{2}{*}{$\begin{array}{l}\text { Percentage } \\
\text { composition }\end{array}$} \\
\hline & Pre-bloom & Bloom & Post-bloom & & & \\
\hline Hydra & 0 & 0 & 0 & 0 & 0 & 0.00 \\
\hline Dugesia & 0 & 0 & 0 & 0 & 0 & 0.00 \\
\hline microturbellarians undet. & 0 & 0 & 0 & 0 & 0 & 0.00 \\
\hline mermithids & 4 & 27 & 44 & 25 & 20 & 0.13 \\
\hline Enchytraeidae & 0 & 0 & 0 & 0 & 0 & 0.00 \\
\hline Arcteonais lomondi & 0 & 0 & 0 & 0 & 0 & 0.00 \\
\hline Dero spp. & 60 & 838 & 13,367 & 4,755 & 27 & 24.02 \\
\hline Nais spp. & 0 & 0 & 0 & 0 & 0 & 0.00 \\
\hline Slavina appendiculata & 0 & 0 & 0 & 0 & 0 & 0.00 \\
\hline Stylaria & 0 & 0 & 0 & 0 & 0 & 0.00 \\
\hline Naidinae undet. & 0 & 0 & 0 & 0 & 0 & 0.00 \\
\hline Aulodrilus pigueti & 76 & 200 & 2,175 & 817 & 26 & 4.13 \\
\hline Ilyodrilus frantzi & 2,582 & 2,175 & 6,050 & 3,602 & 27 & 18.20 \\
\hline cf. Limnodrilus hoffmeisteri & 31 & 49 & 115 & 65 & 24 & 0.33 \\
\hline Limnodrilus silvani & 0 & 0 & 0 & 0 & 0 & 0.00 \\
\hline Quistadrilus multisetosus & 2 & 9 & 69 & 27 & 11 & 0.13 \\
\hline Rhyacodrilus & 0 & 0 & 0 & 0 & 0 & 0.00 \\
\hline Spirosperma ferox & 0 & 0 & 0 & 0 & 0 & 0.00 \\
\hline Spirosperma nikolskyi & 0 & 0 & 0 & 0 & 0 & 0.00 \\
\hline Varichaetadrilus pacificus & 26 & 44 & 53 & 41 & 24 & 0.21 \\
\hline Varichaetadrilus nr. pacificus & 2,141 & 1,318 & 2,140 & 1,866 & 27 & 9.43 \\
\hline Tubificinae with hairs small & 2,043 & 1,246 & 527 & 1,272 & 27 & 6.43 \\
\hline Bothrioneurum veidovskyanum & 0 & 0 & 0 & 0 & 0 & 0.00 \\
\hline Tubificinae without hairs small & 298 & 229 & 1,457 & 661 & 27 & 3.34 \\
\hline Tubificinae very small & 128 & 497 & 489 & 371 & 26 & 1.88 \\
\hline
\end{tabular}




\begin{tabular}{|c|c|c|c|c|c|c|}
\hline \multirow[b]{2}{*}{ Taxon } & \multirow[b]{2}{*}{ Pre-bloom } & \multicolumn{2}{|c|}{$\begin{array}{l}\text { Mean density } \\
\text { (individuals } \mathrm{m}^{-2} \text { ) }\end{array}$} & \multirow[t]{2}{*}{$\begin{array}{l}\text { Mean density } \\
\text { for the three } \\
\text { sampling } \\
\text { periods } \\
\text { (individuals } \mathrm{m}^{-2} \text { ) }\end{array}$} & \multirow[t]{2}{*}{ Constancy } & \multirow[t]{2}{*}{$\begin{array}{l}\text { Percentage } \\
\text { composition }\end{array}$} \\
\hline & & Bloom & Post-bloom & & & \\
\hline Altmanella freidris & 64 & 157 & 210 & 144 & 27 & 0.73 \\
\hline Lumbriculus & 0 & 0 & 0 & 0 & 0 & 0.00 \\
\hline Rhynchelmis klamathensis & 49 & 66 & 55 & 57 & 27 & 0.29 \\
\hline Rhynchelmis cocoons & 0 & 0 & 105 & 35 & 4 & 0.18 \\
\hline Glossiphonia complanata & 0 & 0 & 0 & 0 & 0 & 0.00 \\
\hline Helobdella bowermani & 241 & 523 & 453 & 406 & 27 & 2.05 \\
\hline Helobdella $\mathrm{nr}$. bowermani & 206 & 349 & 1,714 & 756 & 27 & 3.82 \\
\hline Helobdella $\mathrm{nr}$. robusta & 352 & 702 & 1,027 & 694 & 27 & 3.50 \\
\hline Helobdella stagnalis & 0 & 0 & 0 & 0 & 0 & 0.00 \\
\hline Helobdella hatchlings undet. & 338 & 643 & 975 & 652 & 27 & 3.29 \\
\hline Theromyzon sp. & 0 & 0 & 1 & 0 & 1 & 0.00 \\
\hline Mooreobdella microstoma & 0 & 0 & 2 & 1 & 2 & 0.00 \\
\hline Erpobdellidae undet. & 0 & 0 & 0 & 0 & 0 & 0.00 \\
\hline Piscicolidae & 10 & 6 & 71 & 29 & 16 & 0.15 \\
\hline Caecidotea cf. occidentalis & 0 & 0 & 0 & 0 & 0 & 0.00 \\
\hline Gammarus & 0 & 1 & 1 & 1 & 2 & 0.00 \\
\hline Hyalella & 0 & 2 & 1 & 1 & 3 & 0.00 \\
\hline Baetidae undet. & 1 & 0 & 0 & 0 & 1 & 0.00 \\
\hline Caenis & 0 & 0 & 0 & 0 & 0 & 0.00 \\
\hline Coenagrionidae undet. & 1 & 0 & 0 & 0 & 1 & 0.00 \\
\hline Isoperla & 0 & 0 & 0 & 0 & 0 & 0.00 \\
\hline Corixidae undet. & 0 & 1 & 2 & 1 & 3 & 0.00 \\
\hline Sialis & 0 & 0 & 0 & 0 & 0 & 0.00 \\
\hline Hydroptila & 0 & 0 & 0 & 0 & 0 & 0.00 \\
\hline Limnephilus & 0 & 0 & 0 & 0 & 0 & 0.00 \\
\hline Mystacides & 0 & 0 & 0 & 0 & 0 & 0.00 \\
\hline Oecetis & 0 & 0 & 2 & 1 & 2 & 0.00 \\
\hline Brychius & 0 & 0 & 0 & 0 & 0 & 0.00 \\
\hline Dytiscidae & 0 & 0 & 0 & 0 & 0 & 0.00 \\
\hline
\end{tabular}




\begin{tabular}{|c|c|c|c|c|c|c|}
\hline \multirow[b]{2}{*}{ Taxon } & \multirow[b]{2}{*}{ Pre-bloom } & \multicolumn{2}{|c|}{$\begin{array}{c}\text { Mean density } \\
\text { (individuals } \mathrm{m}^{-2} \text { ) }\end{array}$} & \multirow[t]{2}{*}{$\begin{array}{l}\text { Mean density } \\
\text { for the three } \\
\text { sampling } \\
\text { periods } \\
\text { (individuals } \mathrm{m}^{-2} \text { ) }\end{array}$} & \multirow[t]{2}{*}{ Constancy } & \multirow[t]{2}{*}{$\begin{array}{l}\text { Percentage } \\
\text { composition }\end{array}$} \\
\hline & & Bloom & Post-bloom & & & \\
\hline Dubiraphia & 0 & 0 & 0 & 0 & 0 & 0.00 \\
\hline Bezzia & 0 & 0 & 0 & 0 & 0 & 0.00 \\
\hline Procladius sp. 1 & 1,210 & 694 & 476 & 793 & 27 & 4.01 \\
\hline Orthocladiinae & 0 & 0 & 1 & 0 & 1 & 0.00 \\
\hline Chironomus cf. plumosus & 1 & 152 & 2,251 & 801 & 15 & 4.05 \\
\hline Chironomus cf. utahensis & 0 & 83 & 62 & 48 & 13 & 0.24 \\
\hline cf. Chironomus e.i. & 1 & 561 & 790 & 451 & 19 & 2.28 \\
\hline Cryptochironomus & 2 & 37 & 5 & 14 & 11 & 0.07 \\
\hline Cryptotendipes & 377 & 1,278 & 205 & 620 & 26 & 3.13 \\
\hline Dicrotentipes & 0 & 27 & 6 & 11 & 10 & 0.05 \\
\hline Glyptotendipes sp. 1 & 0 & 2 & 2 & 1 & 3 & 0.01 \\
\hline Parachironomus & 1 & 21 & 22 & 14 & 10 & 0.07 \\
\hline Chironomini "Harnischia comp." e.i. & 0 & 0 & 0 & 0 & 0 & 0.00 \\
\hline Chironomini undet & 4 & 179 & 117 & 100 & 21 & 0.50 \\
\hline Cladotanytarsus & 370 & 82 & 90 & 181 & 22 & 0.91 \\
\hline Tanytarsini & 23 & 467 & 937 & 476 & 22 & 2.40 \\
\hline cf. Hygrobates & 0 & 0 & 0 & 0 & 0 & 0.00 \\
\hline cf. Piona & 0 & 0 & 2 & 1 & 2 & 0.00 \\
\hline Mite undet. & 0 & 1 & 2 & 1 & 3 & 0.00 \\
\hline Valvata & 0 & 0 & 0 & 0 & 0 & 0.00 \\
\hline Fluminicola & 0 & 1 & 0 & 0 & 1 & 0.00 \\
\hline Pyrgulopsis & 0 & 0 & 0 & 0 & 0 & 0.00 \\
\hline Planorbidae spp. & 0 & 1 & 0 & 0 & 1 & 0.00 \\
\hline Sphaeriidae undet. & 0 & 0 & 4 & 1 & 3 & 0.01 \\
\hline Total mean abundance & 10,643 & 12,668 & 36,078 & 19,796 & & \\
\hline Total richness & 29.0 & 36.0 & 41.0 & 45.0 & & \\
\hline
\end{tabular}


Table 17. Taxonomic list of benthic invertebrates collected in 2013 and 2014 collections.

[spp., species (plural); cf., confer (a species that closely matches another species); nr., near (taxonomically); sp., species; undet., undetermined; e.i., early instar]

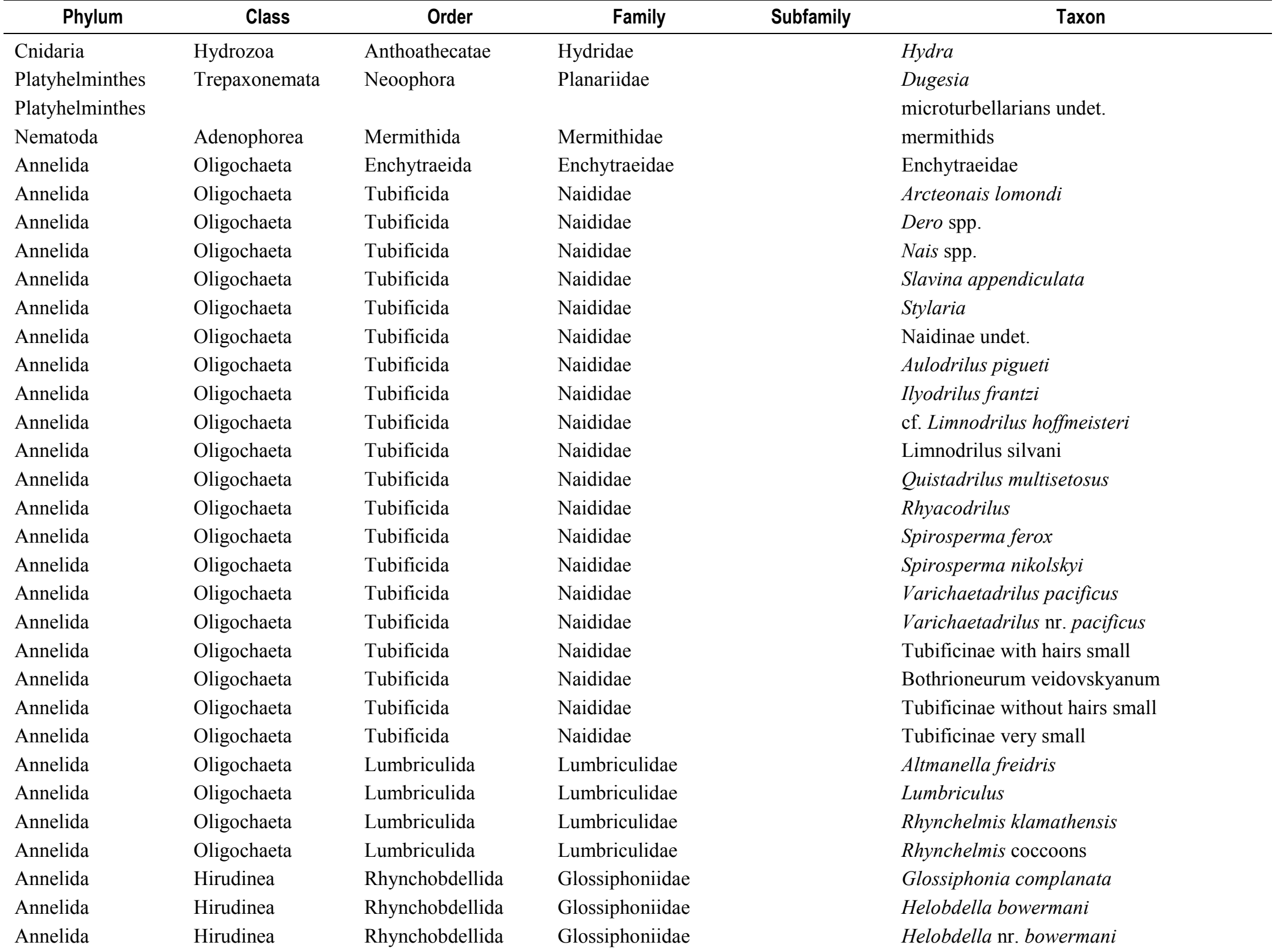




\begin{tabular}{|c|c|c|c|c|c|}
\hline Phylum & Class & Order & Family & Subfamily & Taxon \\
\hline Annelida & Hirudinea & Rhynchobdellida & Glossiphoniidae & & Helobdella nr. robusta \\
\hline Annelida & Hirudinea & Rhynchobdellida & Glossiphoniidae & & Helobdella stagnalis \\
\hline Annelida & Hirudinea & Rhynchobdellida & Glossiphoniidae & & Helobdella hatchlings undet. \\
\hline Annelida & Hirudinea & Rhynchobdellida & Glossiphoniidae & & Theromyzon sp. \\
\hline Annelida & Hirudinea & Arhynchobdellida & Erpobdellidae & & Mooreobdella microstoma \\
\hline Annelida & Hirudinea & Arhynchobdellida & Erpobdellidae & & Erpobdellidae undet. \\
\hline Annelida & Hirudinea & Rhynchobdellida & Piscicolidae & & Piscicolidae \\
\hline Arthopoda & Malacostraca & Isopoda & Asellidae & & Caecidotea cf. occidentalis \\
\hline Arthopoda & Malacostraca & Amphipoda & Gammaridae & & Gammarus \\
\hline Arthopoda & Malacostraca & Amphipoda & Hyalellidae & & Hyalella \\
\hline Arthopoda & Insecta & Ephemeroptera & Baetidae & & Baetidae undet. \\
\hline Arthopoda & Insecta & Ephemeroptera & Caenidae & & Caenis \\
\hline Arthopoda & Insecta & Odonata & Coenagrionidae & & Coenagrionidae undet. \\
\hline Arthopoda & Insecta & Plecoptera & Perlodidae & & Isoperla \\
\hline Arthopoda & Insecta & Hemiptera & Corixidae & & Corixidae undet. \\
\hline Arthopoda & Insecta & Megaloptera & Sialidae & & Sialis \\
\hline Arthopoda & Insecta & Trichoptera & Hydroptilidae & & Hydroptila \\
\hline Arthopoda & Insecta & Trichoptera & Limnephilidae & & Limnephilus \\
\hline Arthopoda & Insecta & Trichoptera & Leptoceridae & & Mystacides \\
\hline Arthopoda & Insecta & Trichoptera & Leptoceridae & & Oecetis \\
\hline Arthopoda & Insecta & Coleoptera & Haliplidae & & Brychius \\
\hline Arthopoda & Insecta & Coleoptera & Dytiscidae & & Dytiscidae \\
\hline Arthopoda & Insecta & Coleoptera & Elmidae & & Dubiraphia \\
\hline Arthopoda & Insecta & Diptera & Ceratopogonidae & & Bezzia \\
\hline Arthopoda & Insecta & Diptera & Chironomidae & Tanypodinae & Procladius sp. 1 \\
\hline Arthopoda & Insecta & Diptera & Chironomidae & Orthocladiinae & Orthocladiinae \\
\hline Arthopoda & Insecta & Diptera & Chironomidae & Chironominae & Chironomus cf. plumosus \\
\hline Arthopoda & Insecta & Diptera & Chironomidae & Chironominae & Chironomus cf. utahensis \\
\hline Arthopoda & Insecta & Diptera & Chironomidae & Chironominae & cf. Chironomus e.i. \\
\hline Arthopoda & Insecta & Diptera & Chironomidae & Chironominae & Cryptochironomus \\
\hline Arthopoda & Insecta & Diptera & Chironomidae & Chironominae & Cryptotendipes \\
\hline Arthopoda & Insecta & Diptera & Chironomidae & Chironominae & Dicrotentipes \\
\hline Arthopoda & Insecta & Diptera & Chironomidae & Chironominae & Glyptotendipes sp. 1 \\
\hline Arthopoda & Insecta & Diptera & Chironomidae & Chironominae & Parachironomus \\
\hline
\end{tabular}




\begin{tabular}{|c|c|c|c|c|c|}
\hline Phylum & Class & Order & Family & Subfamily & Taxon \\
\hline Arthopoda & Insecta & Diptera & Chironomidae & Chironominae & Chironomini "Harnischia comp." e.i. \\
\hline Arthopoda & Insecta & Diptera & Chironomidae & Chironominae & Chironomini undet \\
\hline Arthopoda & Insecta & Diptera & Chironomidae & Chironominae & Cladotanytarsus \\
\hline Arthopoda & Insecta & Diptera & Chironomidae & Chironominae & Tanytarsini \\
\hline Arthopoda & Arachnida & Trombidiformes & Hygrobatidae & & cf. Hygrobates \\
\hline Arthopoda & Arachnida & Trombidiformes & Pionidae & & cf. Piona \\
\hline Arthopoda & Arachnida & & & & Mite undet. \\
\hline Mollusca & Gastropoda & Hererostropha & Valvatidae & & Valvata \\
\hline Mollusca & Gastropoda & Neotaenioglossa & Hydrobiidae & & Fluminicola \\
\hline Mollusca & Gastropoda & Neotaenioglossa & Hydrobiidae & & Pyrgulopsis \\
\hline Mollusca & Gastropoda & Basommatophora & Planorbidae & & Planorbidae spp. \\
\hline Mollusca & Bivalvia & Veneroida & Pisidiidae & & Sphaeriidae undet. \\
\hline
\end{tabular}


Table 18. Phosphorus release (efflux) by some of the most numerically dominant and widespread taxa residing in Upper Klamath Lake.

[ $\mu \mathrm{g}$ SRP-P ind ${ }^{-1} \mathrm{~d}^{-1}$, microgram of soluble reactive phosphorus as phosphorus per individual per day; inds $\mathrm{m}^{-2}$, individuals per square meter; S.D., standard deviation for the specified $\mathrm{n}$ estimates; $\mathrm{mg} \mathrm{L}^{-1}$, milligram per liter; nr., near (taxonomically); cf., confer (a species that closely matches another species); e.i., early instar. Density is based on mean density of taxa determined from the 2013 spatial collections. Spatial collections occurred on three dates: May 23, June 13, and July 3, 2013, at 21 randomly selected sites throughout the lake. Although some Helobdella individuals were too small to identify to species, efflux was estimated for the taxon, but no density data were available to scale their contribution to total efflux]

\begin{tabular}{|c|c|c|c|c|c|}
\hline Taxon & $\mathrm{n}$ & $\begin{array}{c}\text { Mean efflux } \\
\mu \mathrm{g} \text { SRP-P ind }{ }^{-1} d^{-1}\end{array}$ & S.D. & $\begin{array}{l}\text { Density } \\
\text { inds } \mathrm{m}^{-2}\end{array}$ & $\begin{array}{c}\text { Efflux } \\
\text { mg SRP-P } \mathrm{m}^{-2} \mathrm{~d}^{-1}\end{array}$ \\
\hline Ilyodrilus frantzi & 56 & 0.055 & 0.091 & 1,770 & 0.098 \\
\hline Varichaetadrilus nr. pacificus & 32 & 0.118 & 0.121 & 1,513 & 0.178 \\
\hline Rhynchelmis klamathensis & 16 & 1.250 & 0.824 & 260 & 0.325 \\
\hline Helobdella & 22 & 1.408 & 0.579 & & \\
\hline Helobdella $\mathrm{nr}$. bowermani & 3 & 1.747 & 1.118 & 686 & 1.198 \\
\hline Helobdella robusta & 4 & 0.880 & 0.749 & 281 & 0.247 \\
\hline Mooreobdella & 3 & 17.139 & 3.872 & 12 & 0.214 \\
\hline Procladius & 2 & 0.546 & 0.108 & 1,352 & 0.739 \\
\hline Chironomus plumosus & 297 & 0.843 & 1.092 & 47 & 0.039 \\
\hline Chironomus cf. plumosus e.i. & 6 & 0.213 & 0.104 & 508 & 0.108 \\
\hline Chironomus utahensis & 2 & 0.141 & 0.097 & 28 & 0.004 \\
\hline Cryptochironomus & 18 & 1.920 & 1.253 & 35 & 0.066 \\
\hline Cryptotendipes & 1 & 0.053 & & 169 & 0.009 \\
\hline Fluminicola & 8 & 0.669 & 0.415 & 51 & 0.034 \\
\hline Total & 470 & & & 6,711 & 3.259 \\
\hline
\end{tabular}

Formulation of Artificial Lake Water

for efflux experiments

\begin{tabular}{lc}
\multicolumn{1}{c}{ Constituent } & \multicolumn{1}{c}{$\mathrm{mg} \mathrm{L}^{-1}$} \\
\hline $\mathrm{KCl}$ & 3.73 \\
$\mathrm{MgSO}_{-4}$ & 12.32 \\
$\mathrm{CaCl}_{2}$ & 16.65 \\
$\mathrm{NaHCO}_{3}$ & 23.52 \\
\hline
\end{tabular}


Table 19. Potential importance of solute advective flux across the sediment-water interface.

[Available at http://dx.doi.org/10.3133/ofr20161175.] 
Table 20. Environmental variables and floc population properties, Upper Klamath Lake, Oregon, May 6, 2015.

[SPMC, suspended particulate matter concentration; $\mathrm{mg} \mathrm{L}^{-1}$, milligram per liter; $\mathrm{m}$, meter; mm, millimeter; mm $\mathrm{s}^{-1}$, millimeter per second; $\mathrm{kg} \mathrm{m}^{-3}$, kilogram per cubic meter; D, particle size; Ws, settling velocity; $\rho_{\mathrm{e}}$, density; MSF, mass settling flux; $\mathrm{mg} \mathrm{m}^{-2} \mathrm{~s}^{-1}$, milligram per square meter per second]

\begin{tabular}{|c|c|c|c|c|}
\hline Sample \# & 0515_S01 & 0515_S03 & 0515_S04 & 0515_S06 \\
\hline Station and sampling depth & ML $d p \_10$ & ML $d p \_90$ & LS01 $d p \_10$ & LS01 $d p \_90$ \\
\hline $\operatorname{SPMC}\left(\mathrm{mg} \mathrm{L}^{-1}\right)$ & 25 & 140 & 4.5 & 11 \\
\hline Water depth (m) & 4.5 & 4.5 & 2.2 & 2.2 \\
\hline Number of flocs & 94 & 364 & 22 & 44 \\
\hline Number of macroflocs & 5 & 73 & - & 2 \\
\hline $\mathrm{D}_{\text {mean }}(\mathrm{mm})$ & 84 & 122 & 66 & 79 \\
\hline $\mathrm{Ws}_{\text {mean }}\left(\mathrm{mm} \mathrm{s}^{-1}\right)$ & 1.62 & 3.28 & 0.57 & 0.9 \\
\hline$\rho_{\mathrm{e} \_ \text {mean }}\left(\mathrm{kg} \mathrm{m}^{-3}\right)$ & 560 & 540 & 263 & 365 \\
\hline Porosity $_{\text {mean }}(\%)$ & 53 & 57 & 79 & 71 \\
\hline $\mathrm{Ws}_{\text {macro }}\left(\mathrm{mm} \mathrm{s}^{-1}\right)$ & 6.35 & 3.34 & - & 1.1 \\
\hline $\mathrm{Ws}_{\text {micro }}\left(\mathrm{mm} \mathrm{s}^{-1}\right)$ & 1.36 & 3.26 & 0.57 & 0.89 \\
\hline$\rho_{\mathrm{e} \_ \text {macro }}\left(\mathrm{kg} \mathrm{m}^{-3}\right)$ & 103 & 188 & - & 39 \\
\hline Porosity ${ }_{\text {macro }}(\%)$ & 92 & 85 & - & 97 \\
\hline Macroflocs ( $\%$ by mass) & $21.3 \%$ & $31.1 \%$ & - & $13.8 \%$ \\
\hline $\operatorname{MSF}_{\text {macro }}(\%$ of total MSF $)$ & $54.7 \%$ & $30.6 \%$ & - & $14.0 \%$ \\
\hline Mass setting flux ( $\mathrm{mg} \mathrm{m}^{-2} \mathrm{~s}^{-1}$ ) & 62 & 464 & 2.82 & 11.5 \\
\hline
\end{tabular}


Table 21. Environmental variables and floc population properties, Upper Klamath Lake, Oregon, July 30, 2015.

[SPMC, suspended particulate matter concentration; $\mathrm{mg} \mathrm{L}^{-1}$, milligram per liter; $\mathrm{m}$, meter; mm, millimeter; mm $\mathrm{s}^{-1}$, millimeter per second; $\mathrm{kg} \mathrm{m}^{-3}$, kilogram per cubic meter; D, particle size; Ws, settling velocity; $\rho_{\mathrm{e}}$, density; MSF, mass settling flux; $\mathrm{mg} \mathrm{m}^{-2} \mathrm{~s}^{-1}$, milligram per square meter per second]

\begin{tabular}{|c|c|c|c|c|}
\hline Sample \# & 0715_S01 & 0715_S03 & 0715_S04 & 0715_S06 \\
\hline Station and sampling depth & ML $d p \_10$ & ML $d p \_90$ & $\mathrm{LS} 01 d p \_10$ & LS01 $d p \_90$ \\
\hline $\operatorname{SPMC}\left(\mathrm{mg} \mathrm{L}^{-1}\right)$ & 8 & 21 & 32 & 316 \\
\hline Water depth (m) & 3.9 & 3.9 & 1.6 & 1.6 \\
\hline Number of flocs & 17 & 38 & 58 & 330 \\
\hline Number of macroflocs & 9 & 23 & 27 & 275 \\
\hline $\mathrm{D}_{\text {mean }}(\mathrm{mm})$ & 167 & 178 & 175 & 305 \\
\hline $\mathrm{Ws}_{\text {mean }}\left(\mathrm{mm} \mathrm{s}^{-1}\right)$ & 1.48 & 1.67 & 0.40 & 3.86 \\
\hline$\rho_{\mathrm{e} \_ \text {mean }}\left(\mathrm{kg} \mathrm{m}^{-3}\right)$ & 92 & 170 & 43 & 81 \\
\hline Porosity $_{\text {mean }}(\%)$ & 93 & 86 & 97 & 94 \\
\hline $\mathrm{Ws}_{\text {macro }}\left(\mathrm{mm} \mathrm{s}^{-1}\right)$ & 2.31 & 1.83 & 0.49 & 4.46 \\
\hline $\mathrm{Ws}_{\text {micro }}\left(\mathrm{mm} \mathrm{s}^{-1}\right)$ & 0.55 & 1.41 & 0.33 & 0.86 \\
\hline$\rho_{\mathrm{e} \_ \text {macro }}\left(\mathrm{kg} \mathrm{m}^{-3}\right)$ & 79 & 72 & 15 & 75 \\
\hline Porosity $_{\text {macro }}(\%)$ & 94 & 94 & 99 & 94 \\
\hline Macroflocs ( $\%$ by mass) & $69.3 \%$ & $77.9 \%$ & $66.8 \%$ & $93.8 \%$ \\
\hline $\mathrm{MSF}_{\text {macro }}(\%$ of total MSF $)$ & $91.5 \%$ & $79.7 \%$ & $75.2 \%$ & $98.8 \%$ \\
\hline Mass setting flux ( $\left.\mathrm{mg} \mathrm{m}^{-2} \mathrm{~s}^{-1}\right)$ & 14.8 & 36.6 & 14.8 & 1,580 \\
\hline
\end{tabular}


Table 22. Environmental variables and floc population properties, Upper Klamath Lake, Oregon, October $6,2015$.

[SPMC, suspended particulate matter concentration; $\mathrm{mg} \mathrm{L}^{-1}$, milligram per liter; $\mathrm{m}$, meter; mm, millimeter; mm $\mathrm{s}^{-1}$, millimeter per second; $\mathrm{kg} \mathrm{m}^{-3}$, kilogram per cubic meter; D, particle size; Ws, settling velocity; $\rho_{\mathrm{e}}$, density; MSF, mass settling flux; $\mathrm{mg} \mathrm{m}^{-2} \mathrm{~s}^{-1}$, milligram per square meter per second]

\begin{tabular}{|c|c|c|c|c|}
\hline Sample \# & 1015_S01 & 1015_S03 & 1015_S04 & 1015_S06 \\
\hline Station and sampling depth & ML $d p \_10$ & ML $d p \_90$ & $\mathrm{LS} 01 d p_{-} 10$ & LS01 $d p \_90$ \\
\hline $\operatorname{SPMC}\left(\mathrm{mg} \mathrm{L}^{-1}\right)$ & 10 & 62 & 49 & 828 \\
\hline Water depth (m) & 3.1 & 3.1 & 0.7 & 0.7 \\
\hline Number of flocs & 17 & 101 & 112 & 1095 \\
\hline Number of Macroflocs & 8 & 64 & 33 & 718 \\
\hline $\mathrm{D}_{\text {mean }}(\mathrm{mm})$ & 186 & 195 & 138.5 & 238.5 \\
\hline $\mathrm{Ws}_{\text {mean }}\left(\mathrm{mm} \mathrm{s}^{-1}\right)$ & 3.72 & 3.45 & 1.32 & 3.91 \\
\hline$\rho_{\mathrm{e} \_ \text {mean }}\left(\mathrm{kg} \mathrm{m}^{-3}\right)$ & 302 & 167 & 190 & 220 \\
\hline Porosity $_{\text {mean }}(\%)$ & 76 & 87 & 85 & 83 \\
\hline $\mathrm{Ws}_{\text {macro }}\left(\mathrm{mm} \mathrm{s}^{-1}\right)$ & 5.67 & 4.57 & 2.37 & 4.74 \\
\hline $\mathrm{Ws}_{\text {micro }}\left(\mathrm{mm} \mathrm{s}^{-1}\right)$ & 1.99 & 1.51 & 0.88 & 2.31 \\
\hline$\rho_{\mathrm{e} \_ \text {macro }}\left(\mathrm{kg} \mathrm{m}^{-3}\right)$ & 214 & 155 & 53 & 122 \\
\hline Porosity $_{\text {macro }}(\%)$ & 83 & 88 & 96 & 90 \\
\hline Macroflocs ( $\%$ by mass) & $71.3 \%$ & $77.2 \%$ & $57.1 \%$ & $84.2 \%$ \\
\hline $\operatorname{MSF}_{\text {macro }}(\%$ of total MSF $)$ & $85.5 \%$ & $91.3 \%$ & $78.9 \%$ & $92.1 \%$ \\
\hline Mass setting flux $\left(\mathrm{mg} \mathrm{m}^{-2} \mathrm{~s}^{-1}\right)$ & 43.94 & 258.03 & 99.85 & 4,139 \\
\hline
\end{tabular}

